\author{
UNIVERSIDADE DE SÃO PAULO \\ FACULDADE DE FILOSOFIA, LETRAS E CIÊNCIAS HUMANAS \\ DEPARTAMENTO DE LINGUÍSTICA \\ PROGRAMA DE PÓS-GRADUAÇ̃̃O EM SEMIÓTICA E LINGUÍSTICA GERAL \\ DANiel CARMona Leite \\ Semiótica da emancipação: um olhar \\ sobre esse momento de passagem no \\ período da juventude
}

São Paulo

2015 


\title{
Semiótica da emancipação: um olhar sobre esse momento de passagem no período da
}

\author{
juventude \\ DANiel CARMona LeITE \\ daniel.leite@usp.br
}

Dissertação apresentada ao Programa de Pós-Graduação em Semiótica e Linguística Geral do Departamento de Linguística da Faculdade de Filosofia, Letras e Ciências Humanas da Universidade de São Paulo para obtenção do título de Mestre em Linguística.

Orientador: Prof. Dr. Luiz Augusto de Moraes Tatit

De acordo:

São Paulo

2015 
Nome: LEITE, Daniel Carmona

Título: Semiótica da emancipação: um olhar sobre esse momento de passagem no período da juventude

\author{
Dissertação apresentada ao Programa de \\ Pós-Graduação em Semiótica e Linguística \\ Geral do Departamento de Linguística da \\ Faculdade de Filosofia, Letras e Ciências \\ Humanas da Universidade de São Paulo \\ para obtenção do título de Mestre em \\ Linguística.
}

Orientador: Prof. Dr. Luiz Augusto de Moraes Tatit

Aprovado em ___ 2015.

Banca examinadora:

Prof. Dr.:

Instituição:

Julgamento:

Assinatura:

Prof. Dr.:

Instituição:

Julgamento:

Assinatura:

Prof. Dr.:

Instituição:

Julgamento:

Assinatura: 


\section{Agradecimentos}

Em primeiro lugar, gostaria de ser grato a todos os que de alguma forma estiveram presentes durante o processo de gestação e formulação do projeto: Profa. Taís Bressane, Rita Carmona, Mestra Janja Costa Araújo, Taata Mutá Imê, Geraldo Leite e Beth Carmona. Ao Mestre Gabriel pela luz na consciência.

Ao Prof. Luiz Tatit pela generosidade e pelas orientações precisas e necessárias.

Também às Profas. Renata Mancini e Elizabeth Harkot-de-La-Taille por suas contribuições valiosas durante a etapa de qualificação. Demonstro minha sincera gratidão a cada um dos entrevistados, pela disposição de ofertar as suas histórias. Agradecimentos especiais também a Paula Martins de Souza, Alpha Condeixa Simonetti, Renata Moreira e demais colegas e professores do GESUSP, pelo companheirismo, compartilhamento e revisão.

Ao Conselho Nacional de Desenvolvimento Científico e Tecnológico (CNPq), pela bolsa concedida para a realização deste trabalho. 


\section{Resumo}

LEITE, Daniel Carmona (2015) Semiótica da emancipação: um olhar sobre esse momento de passagem no período da juventude. Dissertação (Mestrado) - Faculdade de Filosofia, Letras e Ciências Humanas, Universidade de São Paulo, São Paulo, 2015.

O conceito de emancipação vem sendo mencionado no âmbito das discussões sobre juventude no Brasil e no mundo. A semiótica de linha francesa pode agregar reflexões importantes a seu estudo, de modo que as análises desta dissertação tomam como base teórica, sobretudo, as obras de Algirdas Julien Greimas e Claude Zilberberg.

O corpus é composto por entrevistas realizadas com jovens habitantes da cidade de São Paulo e o principal tema abordado pelos textos orais é a transição à vida adulta, considerandose, nessa passagem, por exemplo, as saídas (ou não) da casa dos pais ou as buscas profissionais e pessoais relatadas. Além das entrevistas, são analisados os capítulos iniciais da épica africana Sundjata, ou A epopeia mandinga, de Djibril Tamsir Niane. Dentre os resultados obtidos destacam-se a constatação de que, por um lado, o tratamento narrativo prevalece nos discursos sobre a emancipação e, por outro, a noção de acontecimento (objeto da semiótica tensiva) quase sempre se manifesta na etapa da juventude.

Palavras-chave: semiótica, emancipação, juventude 


\section{Abstract}

LEITE, Daniel Carmona (2015) Emancipation semiotics: a glimpse on this passage in the time of the youth. (Master's thesis) - Faculdade de Filosofia, Letras e Ciências Humanas, Universidade de São Paulo, São Paulo, 2015.

The concept of emancipation is often mentioned nowadays in the discussions about youth in Brazil and around the world. The French School of Semiotics can offer contributions to the study of this object. So, this master's thesis makes use of the works of authors such as Algirdas Julien Greimas and Claude Zilberberg as theoretical basis.

The corpus is composed by interviews that were taken of young inhabitants of Sao Paulo city (Brazil). The main theme that was addressed by the reports is the transition to adulthood. In this matter, the informants talked, for example, about leaving (or not) their parent's houses and about the paths that they had to go through, in order to achieve professional or personal growth. Besides the interviews, the initial chapters of the African epic Soundjata, ou L'Épopée Mandingue, by Djibril Tamsir Niane, were also analyzed. Among the main results obtained, it is possible to mention the presence of the narrative treatment in the speeches about emancipation, as well as the notion of happening (object of the tensive semiotics), that is frequently manifested in the stage of the youth.

Keywords: semiotics, emancipation, youth 
$\begin{array}{ll}0 . \text { Introdução } & 1\end{array}$

0.1 Conceito de emancipação e termos relacionados 3

$\begin{array}{lr}0.2 \text { Alforria } & 9\end{array}$

$\begin{array}{ll}0.3 \text { Referências legais brasileiras } & 11\end{array}$

0.3.1 Emancipação segundo o Código Civil 12

0.3.2 Estatuto da Criança e do Adolescente e Estatuto da Juventude 17

$\begin{array}{ll}\text { 0.3.2.1 Identidade e diversidade } & 19\end{array}$

$\begin{array}{ll}\text { 0.3.2.2 Discriminação } & 21\end{array}$

$\begin{array}{ll}\text { 0.3.3 Perfil dos documentos } & 22\end{array}$

1. Fidúcia em "Sundjata, ou A epopeia mandinga" 24

1.1 Sinopse da trama 25

$\begin{array}{ll}1.2 \text { Narê Maghan } & 26\end{array}$

$\begin{array}{ll}\text { 1.2.1 O rei e seu filho } & 31\end{array}$

1.2.2 Valores tensivos do desenvolvimento de Sundjata 33

$\begin{array}{ll}\text { 1.2.3 Confiança } & 34\end{array}$

1.3 Sogolon Kedju $\quad 36$

1.4 Manipulação do protagonista 41

2. Discursividade da emancipação nas entrevistas 43

2.1 Panoramas temático e figurativo articulados em foria 43

$\begin{array}{ll}\text { 2.2 Dependência e independência } & 48\end{array}$

$\begin{array}{ll}2.3 \text { Actorialização e espacialização } & 50\end{array}$ 
2.5 Engajamento e transformação social 57

$\begin{array}{ll}\text { 2.6 Família e mundo dos adultos } & 60\end{array}$

$\begin{array}{ll}3.1 \text { Manipulação } & 66\end{array}$

$\begin{array}{ll}\text { 3.1.1 Manipulação instauradora } & 67\end{array}$

3.1.1.1 Manipulação reflexiva $\quad 68$

$\begin{array}{ll}\text { 3.1.1.2 Manipulação transitiva } & 71\end{array}$

3.1.2 Manipulação a partir da emancipação $\quad 75$

$\begin{array}{ll}\text { 3.1.3 Síntese da manipulação } & 78\end{array}$

$\begin{array}{ll}3.2 \text { Virtualização e atualização nas entrevistas } & 78\end{array}$

$\begin{array}{ll}\text { 3.2.1 Modalizações do ser } & 79\end{array}$

3.2.1.1 Modalidade volitiva $\quad 80$

3.2.1.2 Querer-ser e não-querer-ser 83

3.2.1.3 Narratividade e preconceito $\quad 84$

$\begin{array}{ll}\text { 3.2.1.4 Imagens de si } & 87\end{array}$

3.2.1.5 Conclusões parciais $\quad 91$

3.2.2 Modalizações do fazer $\quad 92$

$\begin{array}{ll}\text { 3.2.2.1 Querer-fazer } & 93\end{array}$

3.2.2.2 Contrariedade entre querer e não-poder-fazer 96

3.2.2.3 Contraditoriedade entre querer e poder-não-fazer 102

$\begin{array}{ll}\text { 3.2.2.4 Motivação e fidúcia } & 104\end{array}$

3.2.2.5 Percurso "cíclico" de JS23 109

$\begin{array}{ll}\text { 3.2.2.6 Dever e poder-fazer } & 113\end{array}$

3.2.2.7 Localizando figuras e temas da competencialização 118 
4.1 Algumas considerações tensivas

Anexo 


\section{Introdução}

O fenômeno da emancipação ainda não foi suficientemente estudado pelos teóricos da linguagem e da significação. Até os dias atuais, as abordagens que focam o assunto concentraram-se, sobretudo, nos campos do direito, da história (Almeida, 2007), da antropologia (Gomes e Munanga, 2006) e da sociologia (Barreto, 2008; Pimenta, 2007). Também há pesquisas em áreas relacionadas à saúde, como a psicologia (Imanishi, 2008) e a enfermagem, além da educação (Andrade e Mussi, 2008; Araújo, 2004; Machado, 2011), da educação física e da área das comunicações ${ }^{1}$.

Boa parte dos estudos historiográficos observados dedica-se a compreender o período da escravidão, seus efeitos e causas. Os trabalhos vindos da área do direito transitam em torno de legislação, políticas públicas e direitos humanos, embora também estejam atrelados, por vezes, à temática da escravização dos africanos e descendentes ou à libertação de opressões de naturezas variadas. Dentro dessa variedade de abordagens de emancipação, um número considerável de obras acadêmicas disponíveis no Banco de Dados Bibliográfico da USP (Dedalus) dedica-se a investigar a libertação feminina (enfrentamento da violência de gênero, história da mulher, literatura e representação social da mulher).

Vista como fenômeno de sentido, a emancipação ainda não recebeu um tratamento satisfatório por parte dos pesquisadores desse campo. Assim, a proposta deste trabalho é investigar tal conceito a partir de suas manifestações narrativas, tensivas e discursivas, segundo os diferentes níveis que a semiótica de linha francesa postula. A. J. Greimas e C. Zilberberg, entre outros autores da área, correspondem às bases teóricas deste estudo. $O$ conhecimento nessa área vem sendo desenvolvido com afinco também por pesquisadores brasileiros, como D. L. P. de Barros, J. L. Fiorin e L. Tatit, levados em conta nesta análise. Diálogos com outras áreas do saber são igualmente estabelecidos aqui, tendo sempre em vista a compreensão dos mecanismos que fazem com que esse tipo de libertação seja construído no discurso.

Para a constituição do corpus desta dissertação foram realizadas algumas entrevistas compreensivas $^{2}$ e a seleção de informantes deu-se com base em alguns critérios. 0 primeiro deles é que os entrevistados fossem jovens. O Brasil contava, em 2009, com o maior contingente

\footnotetext{
${ }^{1}$ As referências mencionadas são apenas algumas produções sobre o tema, extraídas da bibliografia da presente dissertação.

${ }^{2}$ Entrevistas compreensivas caracterizam-se por partirem de um breve roteiro de perguntas e pelo fato de que nelas os entrevistadores buscam ao máximo a livre expressão do entrevistado (Harkot-de-La-Taille, 2013, p. 399).
} 
populacional desse segmento de sua história ( 50,5 milhões, $28 \%$ da população). A "ancoragem" no contexto da juventude brasileira deu-se com vistas a um reconhecimento complementar às obras que tratam desse segmento, tão representativo no país nos dias de hoje.

O segundo recorte utilizado na seleção do perfil dos entrevistados - o foco na escuta de pessoas negras - justifica-se pela busca de narrativas não hegemônicas, além de ser este um grupo étnico que se destaca qualitativamente no debate sobre as emancipações na história do país. Os entrevistados habitavam em São Paulo até a data das entrevistas, embora nem todos fossem paulistanos de nascença. Essa escolha justifica-se pelo interesse crescente em se estudar os habitantes das metrópoles. Dados do relatório da ONU Estado das cidades da América Latina e Caribe (2012) expressam a importância de um olhar mais atento às cidades, levando em conta o fato de ser tal região a que possui o maior índice do globo, com quase $80 \%$ de sua população vivendo em áreas urbanas.

O último critério de seleção de informantes deu-se com vistas à obtenção de relatos de experiências relativamente bem-sucedidas de jovens que buscam independência e liberdade em suas vidas. Assim, no momento de escolha dos indivíduos a fornecer relatos para este estudo, tiveram prioridade aqueles que desenvolviam trabalhos reconhecidos nas áreas da emancipação social ou cultural. Como uma maneira de primar pela diversidade do corpus, cada entrevistado veio de um projeto ou área específico, não tendo, a princípio, quaisquer vínculos profissionais ou pessoais uns com os outros.

Ao todo, quatro jovens foram entrevistados, e as conversas duraram entre 15 e 41 minutos. A metodologia utilizada para a coleta dos relatos deu-se com base na proposta do Manual de História Oral (de Meihy, 1996), que auxiliou, entre outras coisas, a abordagem dos informantes e os cuidados com gravação e captação. No que tange à construção de entrevistas compreensivas, Guerra (2006) também aportou algum embasamento metodológico (pp. 11-19).

Os roteiros de entrevista encontram-se transcritos na seção de anexos. Os nomes dos entrevistados, para fins de privacidade, não são revelados. Para identificar cada informante, ao longo da presente dissertação, utilizam-se duas letras em maiúsculas, seguidas das suas idades, em algarismos numéricos (ex. JS23). A transcrição baseou-se no procedimento utilizado pelo projeto NURC, que permite, entre outras coisas, o registro de parte dos recursos prosódicos (truncamentos, entonações, silabações, etc.) presentes nas falas dos informantes (Preti, org., 2000 , pp. $15-16)$.

A dissertação está organizada em quatro capítulos. No primeiro deles, o conceito de fidúcia narrativa é o foco, sendo estudado a partir do texto Sundjata, ou A epopeia mandinga, 
de Djibril Tamsir Niane. O segundo momento, por sua vez, trata dos fenômenos discursivos encontrados nos textos orais coletados. Já a narratividade desse último corpus de pesquisa é abordada no terceiro capitulo, dividido em duas seções: "3.1 Manipulação" e "3.2 Virtualização e atualização nas entrevistas". Durante a quarta etapa de análise apresentam-se as considerações tensivas, acompanhadas de algumas observações de cunho extratextual. Por fim, em "Conclusão", busca-se integrar os resultados obtidos durante toda a presente dissertação, sistematizando e depreendendo, a partir das reflexões feitas em cada capítulo, as generalizações que puderam ser constatadas quanto às estruturas de sentido atuantes na constituição dos entrevistados como pessoas emancipadas.

Ainda nesta introdução, um breve olhar é dedicado a alguns termos relacionados a emancipação e sua conceituação. Após isso, realiza-se um estudo dos textos do universo legislativo que regulam as políticas públicas brasileiras dirigidas ao segmento jovem. Isso se dá com o intuito de efetuar uma fundamentação inicial ao tema estudado, antes da atenção focarse diretamente nos textos do corpus.

\subsection{Conceito de emancipação e termos relacionados}

O entendimento de que emancipação é um conceito composto de atributos que valem por si mesmos não oferece explicações suficientes para uma compreensão satisfatória do fenômeno. Como já demonstrava o "pai" dos estudos linguísticos modernos, Ferdinand de Saussure, em seu Curso de Linguística Geral, "o valor de um [termo] resulta tão-somente da presença simultânea de outros" (1969, p. 133). A langue, como uma rede de relações e de significação, não pode ser concebida apenas pelo funcionamento independente de seus componentes.

Considerando-se esse pensamento, é interessante mapear, ainda que superficialmente, algumas palavras que estão no campo semântico da emancipação. Liberdade, independência e autonomia foram os termos escolhidos, por serem algumas das principais designações relacionadas ao conceito estudado, no âmbito do sistema linguístico do português. Ao serem descritas as semelhanças e as diferenças que essas palavras possuem entre si, o intuito desta rápida análise é efetuar uma recuperação sobre o significado desses conceitos, que, em meio às dessemantizações que são características das realizações linguísticas cotidianas, talvez já 
tenham, de alguma maneira, deixado de chamar atenção, seja ela a dos falantes da língua, seja a do pesquisador que os estuda.

A análise é feita com base em critérios semióticos vindos dos níveis discursivo, narrativo e tensivo, alguns deles introduzidos ao leitor nesse momento. Para a conceituação das palavras, recorre-se às acepções de cada termo presentes no Novo Dicionário Aurélio da Língua Portuguesa (1995) e no Grande Dicionário Houaiss da Língua Portuguesa (versão Beta, s/d). A escolha desses manuais como fontes de referência deu-se por serem obras relativamente consagradas na sociedade, assim como pela grande circulação que possuem em meio a ela.

Antes de começar, para recuperar um pouco do que significam as modalidades dentro do instrumental desenvolvido pelos estudos semióticos, é oportuno citar Greimas e Courtés (2012), que expressam a necessidade de se olhar de uma maneira mais sistemática as modalizações que regem a transformação e a descrição dos enunciados narrativos de modo geral (pp. 314-316, verbete "Modalidade"). Desse modo, ressaltam a importância das categorias modais, atribuindo a elas, os valores querer e dever (virtualizantes), poder e saber (atualizantes) e fazer e ser (realizantes). Para os autores, a aquisição de valores inscreve-se no que se denomina percurso narrativo, fórmula teórica que descreve a progressão do que é o caminho do sujeito ou do destinador "de um ponto ao outro", graças a "instâncias intermediárias" (p. 362).

\section{Independência}

Partindo, agora, para a análise de alguns termos relacionados à emancipação, pode-se afirmar que independência, quando vista sob a ótica de sua origem e uso, remete a uma acepção matemática. Sem aprofundar o foco em tal campo do conhecimento, pode-se afirmar que a noção de probabilidade é importante para a significação do termo nesse registro. A relação entre dois elementos torna-se independente quando, grosso modo, um não exerce influência probabilística sobre o outro. Tanto no Houaiss como no Aurélio, as definições de independência utilizam palavras como "estado", "caráter" ou "condição dos seres". Esses termos remetem à modalidade do ser, que pode ser vista em oposição ao fazer, ambas realizantes. Na semiótica, a primeira é identificada com os traços endógenos e internos, ao passo que a segunda é exógena e externa (Fiorin, 2012, p. 120). Além da categoria do ser, outras modalidades são bastante fecundas para descrever as ideias trazidas pelos dicionários, em especial o poder-não-fazer e não-dever-fazer. Uma definição, extraída do Houaiss, ilustra bem essa proximidade entre independência e as categorias mencionadas: "caráter daquilo ou de quem não adota ideias 
preestabelecidas nem segue as regras e usos correntes / a i.[ndependência] da arte e do artista" (verbete "independência", grifo nosso).

Além da constatação ressaltada acima, o texto do mesmo manual permite observar uma relação existente entre independência e a categoria do saber (atualização), deixando implícito, além disso, também certo "uso" que haveria das modalidades epistêmica (crer) e veridictória (ser e parecer) nesse âmbito. Essas últimas tratam da impressão que os sujeitos têm sobre as coisas ou outros sujeitos do mundo. Outra definição, extraída também do dicionário Houaiss, traz figuras que permitem ver essa proximidade entre a independência e o complexo modal cognitivo: "caráter daquilo ou daquele que não se deixa influenciar e que revela imparcialidade de julgamento" (s/d, verbete "independência", grifos nossos).

Em muitos momentos, as definições do termo levam à constatação de que independência é atributo de um sujeito narrativo atualizado na modalidade do poder-não-fazer. Nesses casos, há convergência com a conceituação dada pela semiótica narrativa à mesma palavra, como se verá adiante. Isso ocorre, por exemplo, quando há definições como "caráter daquele que goza de autonomia" (s/d, verbete "independência", grifo nosso). Outra acepção, "quem tem (...) fartos meios de subsistência" (1995, p. 357, verbete "independente", grifo nosso), aponta ao poder-não-fazer, mas também remete ao poder-fazer, pois se refere à aptidão do sujeito para a ação.

Tratando, agora, da articulação sintática que se dá entre enunciados narrativos, nas definições dos dois dicionários verifica-se a presença do que se denomina, em semiótica, programas pressupostos. Nos casos, o sujeito se encontraria em disjunção com o valor poderfazer ou poder-não-fazer. Esses PNs anteriores configuram a independência como um processo de reversão de uma disposição modal do sujeito de estado. Em outras palavras, o ser que vivia uma situação de dependência deixa de vivê-la. Como exemplo desse fato, pode-se mencionar a definição "restituição ou aquisição dessas autonomias" (1995, p. 357, verbete "independência", grifo nosso). Também é graças a essa forma de construção modal que se pode considerar que as definições estudadas da palavra estão em geral associadas à aspectualidade pontual incoativa ${ }^{3}$.

O regimento da transformação narrativa foi explorado dentro do âmbito da constituição de um modelo estrutural da significação, realizado por Greimas em Sobre o sentido II (2014). O

\footnotetext{
${ }^{3}$ Segundo a distribuição dos termos da aspectualização proposta por Barros (2002, p. 91), que os divide em qualidades durativas (contínuas e descontínuas) e pontuais (anteriores e posteriores). No que toca à organização sintagmática, podem ser incoativas (pontuais), durativas (contínuas ou descontínuas) ou terminativas (pontuais).
} 
foco encontrava-se, então, dirigido, sobretudo, à transformação que o sujeito realiza em seu estado juntivo com o objeto de valor. Tal direcionamento de análise decorria da necessidade de que o instrumental "desse conta" das situações e disposições encontradas nos textos dos quais a semiótica ocupava-se na época. Pouco a pouco, com a necessidade de descrição de textos com maior aprofundamento interno dos personagens, por exemplo, a teoria viu-se obrigada a rever alguns de seus conceitos, focando também a atenção nos estados de alma e nos "acidentes" que se verificavam nos discursos analisados. Ainda assim, muitos dos termos propostos pelo autor lituano nessa obra servem de guia para as reflexões dos dias de hoje. A distinção feita entre os actantes do ser e aqueles do fazer, por exemplo, corresponde a parâmetros que regem a relação entre esses dois tipos de sujeito, tais como a possibilidade (ou não) de sincretismo actancial.

Segundo o autor (pp. 47 - 51), há quatro possibilidades de transformação narrativa no nível do sujeito. Na primeira delas, o sujeito de transformação (S3) é equivalente a um sujeito de estado (S1). Este último encontra-se em disjunção com o objeto de valor e passa à conjunção. A transformação, nesse caso, denomina-se realização reflexiva. No plano figurativo, o mesmo fenômeno chama-se apropriação. Quando o sujeito S3 (operador) é sincretizado com outro sujeito (S2), realizado, e transmite o objeto ao sujeito S1, há o que o teórico chama de realização transitiva. Atribuição é a denominação desse fenômeno no plano figurativo. As duas proposições acima mencionadas contemplam a totalidade das possibilidades de transformação conjuntivas previstas. As transformações disjuntivas, por sua vez, possuem outras denominações. Sempre que um sujeito de transformação (S3) for sincretizado com o sujeito S1, há virtualização reflexiva, ou renúncia, no plano figurativo. Quando há uma equivalência entre S3 e um S2 virtual, há virtualização transitiva, ou desapossamento ${ }^{4}$, no plano figurativo.

À luz das considerações feitas, vê-se que as definições analisadas do termo independência referem-se, no nível narrativo, a uma passagem na qual um sujeito disjunto de determinados valores entra em conjunção com eles. Nesse sentido, trata-se, segundo a tipologia proposta, de uma transformação conjuntiva (p. 50). A partir daí, depreendem-se definições mais reflexivas, como a seguinte: "autonomia política; soberania nacional" (s/d, verbete "independência"); e outras não necessariamente reflexivas, tal como a definição de número seis: "condição material capaz de ensejar uma existência agradável; bem-estar, fortuna,

\footnotetext{
${ }^{4}$ A tradução ao português (2014), feita por Dilson Ferreira da Cruz, chama esta qualidade de expropriação (Greimas, 2014, p. 49).
} 
prosperidade" (s/d, verbete "independência", grifo nosso), que não se refere necessariamente a sincretismo entre sujeito operador e de estado.

Outro ponto teórico vital de ser mencionado quanto à constituição narrativa da independência diz respeito à comunicação de valores modais. A manipulação (fazer-fazer), assim como a transformação (fazer-ser), pode estar articulada em reflexividade (sincretismo actancial) ou transitividade (atores diferentes investindo cada papel). A figura abaixo dispõe a proposta conceitual de maneira esquemática.

\begin{tabular}{|l|c|c|}
\hline & $\begin{array}{c}\text { TRANSFORMAÇÃO } \\
\text { fazer-ser }\end{array}$ & $\begin{array}{c}\text { MANIPULAÇÃO } \\
\text { fazer-fazer }\end{array}$ \\
\hline sincretismo actancial & reflexividade & reflexividade \\
\hline ausência de sincretismo & transitividade & transitividade \\
\hline
\end{tabular}

Figura 1 - Transformação e manipulação sob o critério do sincretismo actancial

As definições de independência do dicionário Houaiss referem-se a situações nas quais há sincretismo actancial entre destinador e destinatário, assim como mencionam momentos nos quais isso não ocorre. Os verbetes do dicionário Aurélio parecem normalmente fazer uso de estruturas nas quais o sincretismo acontece, como se vê na acepção seguinte, "Caráter de quem rejeita qualquer sujeição" (1995, p. 357, verbete "independência”, grifo nosso). Nessa definição, a palavra "qualquer" restringe o uso do termo, considerando-o como próprio do regime de manipulação reflexiva.

\section{Liberdade}

Indo além da ideia de que liberdade é uma qualidade pautada e viabilizada, sobretudo, a partir do querer (tal como consta na definição "agir segundo a própria determinação", do Aurélio, 1995, p. 393), pode-se afirmar que o texto dos dicionários, muitas vezes, remete a um atributo que não depende unicamente da vontade do sujeito para se efetivar. As expressões "grau de independência", "dentro dos limites que lhe faculta a lei" (s/d, verbete "liberdade", grifos nossos), "limites impostos por normas definidas" e "tudo quanto não é proibido por lei" (1995, p. 393, verbete "liberdade", grifos nossos) ajudam a compor esse quadro de relativa 
dependência, da qual não é possível se furtar. Essas concepções de liberdade consideram-na uma condição não inerente aos seres, sendo vista como algo conquistado e que é necessariamente mediado por relações sociais ou limites de outras ordens (naturais, por exemplo). Ou seja, de modo geral, segundo essa proposição, tal fenômeno precisa de "fronteiras" para se constituir. Observado a partir de um olhar aspectual, pode-se dizer que há necessidade de marcos incoativos e terminativos para seu estabelecimento. Tal fato de significação encontra-se claramente expresso na delimitação dos direitos do cidadão, os quais terminam uns quando começam os dos outros.

Outra característica recorrente das definições de liberdade tem a ver com a "negação do ser cativo ou propriedade de outrem" (s/d, verbete "liberdade"). Nesse caso, é importante ressaltar a presença do antidestinador narrativo, que visa a restringir os movimentos do sujeito. Um "lugar comum" de uso da palavra nessa acepção é o próprio ato comunicativo, sob a conhecida fórmula da "liberdade de expressão". Esse tipo de direito refere-se, como se sabe, à possibilidade de comunicação isenta da coação de terceiros e regida pela vontade do sujeito (tal como consta na def. 8 do Houaiss).

Em outras acepções da palavra, identificam-se os temas discursivos da facilidade e da soltura. Esses se relacionam às ideias de fluidez e de liberdade de movimentação. Nesse âmbito, pode-se considerar que liberdade é vista como manifestação afirmativa do programa narrativo diante do antiprograma, regido por forças adversas, contrárias ao progresso do sujeito. Algumas das definições dadas pelos dicionários a essa palavra fazem uso de uma estrutura narrativa de manipulação reflexiva, na qual há sincretismo actancial. Isso se verifica, por exemplo, na seguinte concepção: "Faculdade de cada um de se decidir ou agir segundo a própria determinação" (1995, p. 393, grifo nosso), ressaltado o caráter soberano do indivíduo livre, responsável pela sua própria motivação e competencialização.

As definições consultadas da palavra autonomia parecem estar vinculadas, no nível narrativo, principalmente, à realização reflexiva e, também, de certo modo, à manipulação realizada nesse regime. A segunda definição trazida pelo dicionário Aurélio faz menção ao fazerfazer, quando diz que ela é a "propriedade pela qual o homem pode pretender escolher as leis que regem sua conduta" (1995, p. 74, grifo nosso). Uma acepção dada a esse termo pelos dois dicionários, "distância máxima percorrível por um veículo, sem que haja necessidade de reabastecimento de combustível" (s/d, verbete "autonomia"), com uma abordagem bastante concreta figurativamente, remete à capacidade de se realizar uma ação sem recorrer ao auxílio de fontes externas. 
A palavra emancipação, por sua vez, segundo as definições de dicionário, mostra ter íntima conexão com os termos libertação e alforria. A primeira das duas noções possui relação etimológica com a palavra liberdade, parecendo, porém, mais pontual e incoativa que ela. 0 dicionário Houaiss define libertação como a "ação ou efeito de pôr(-se) em liberdade" (verbete "libertação", grifo nosso), o que, por consequência, leva a aproximar o significado da palavra da execução do "ato de desembaraçar-se", encontrado nas definições de liberdade.

Do ponto de vista etimológico, a palavra latina manceps, ìpis, parece ser uma das constituintes originais do termo aqui estudado, significando àquele que "toma em mão alguma coisa para dela tornar-se o adquirente ou reivindicar-lhe a posse" (s/d, verbete "emancipação", elemento de composição). Tal palavra era utilizada no universo jurídico. O prefixo latino ex-, "movimento para fora, tirado de, acabamento" (s/d, prefixo "ex-"), ao anteceder a construção acima na formação da palavra, complementa a composição do conceito com a ideia de saída ou libertação do domínio de determinada instância. Outra característica formal que se destaca durante a análise dos verbetes da palavra emancipação é o fato de que o verbo emancipar é pronominal e está sujeito à reflexividade. Esse fato de língua reflete uma estrutura de significação, pois é possível pensar em emancipação, segundo os critérios extraídos do nível narrativo, como uma realização reflexiva ou transitiva. Para discutir essa questão, a problemática que gira em torno da alforria é uma interessante fonte de debates.

\subsection{Alforria}

O termo vem da língua árabe, al-hurriîâ, "estado de homem livre, não escravo; liberdade" (s/d, verbete "alforria"). A palavra "alforria" em português enquadra-se, a priori, no campo das realizações ou manipulações transitivas, ou seja, aquelas nas quais há um sujeito operador (ou um destinador) e um sujeito de estado (ou um destinatário), investidos, cada qual, por um ator discursivo. Trata-se de uma liberdade concedida pelo senhor ao indivíduo que havia sido escravizado. Tem-se, aí, um sujeito operador ("senhor") executando a transformação no estado juntivo de um sujeito de estado ("indivíduo escravizado", que se converte em "pessoa livre"). No plano figurativo, isso corresponde a uma atribuição.

A noção acima citada pode ser considerada, de certo modo, romântica, se vista sob a perspectiva historiográfica, pois corrobora a visão de que o fim da escravidão foi fruto de uma ação senhorial, mascarando-se sob a figura de uma "pseudo-generosidade", como mostra o 
artigo de Almeida (2007), que analisa os documentos que descrevem os processos de alforria outorgados na região de Rio das Contas (Bahia) entre 1800 e 1888 (pp. 163 - 166).

A autora conclui que o fato histórico teve mais matizes do que se conhece normalmente. Alguns casos que vêm à luz põem em cheque o fato de que os senhores foram de fato os libertadores dos escravizados. Entre eles, há o exemplo do liberto Antonio, alforriado em verba de testamento, mas que continuava sendo escravizado por três anos depois do falecimento de seu senhor (e sem posse do registro de sua libertação em cartório). Foi necessário que entrasse com uma petição, solicitando ao juiz que fizesse o documento, para que conseguisse efetivar a sua libertação. Nesse caso, a transformação (que culminou na liberdade legal do indivíduo) remete, em boa medida, a uma prática reflexiva.

Quando Almeida menciona os tipos de alforria então existentes, verificam-se cinco classes diferentes de processos. Dentre eles, são mencionadas as alforrias pagas incondicionais (nas quais o indivíduo escravizado tinha que pagar pela própria liberdade), as pagas condicionais (nas quais o senhor, além de exigir pagamento, podia impor condições para a concessão da alforria), as não pagas condicionais (onde apenas havia de se cumprir a condição, sem transferência monetária), as gratuitas e as não identificadas.

Dentre os casos documentados entre 1800 e 1888 em Rio das Contas, apenas 464 de um total de 1777 ocorrências (21,6\% das ocorrências) correspondiam à concessão gratuita, na qual o senhor concedeu liberdade sem exigência de qualquer tipo de pagamento ao indivíduo que havia sido escravizado. Apenas esse montante corresponde às alforrias que se podem considerar plenamente atributivas, no nível discursivo. Indo um pouco mais fundo no acontecido no século XIX na região, faz-se oportuno citar mais um trecho do artigo de Almeida.

“Os dados da Tabela 1 deixam bastante claro que alforriar não era um ato de generosidade do senhor. Somando-se as alforrias não-pagas condicionais (31,3\%) com as demais que envolveram pagamento $(42,4 \%)$, resultam $73,7 \%$ de alforrias que implicaram ônus para o escravo, fosse em dinheiro, trabalho ou ambos. A análise por período indica que as alforrias que envolveram ônus ou condição ao cativo foram constantes durante todo o século (...)" (Almeida, 2007, p. 167)

Considerando-se o quadro das outras três modalidades de alforria do período $(73,7 \%)$, vê-se que a estrutura actancial que melhor descreve a outorga das alforrias é a transformação 
reflexiva, disposição na qual um mesmo ator desempenha os papéis de sujeito da ação e de estado, e que a libertação dos africanos e seus descendentes, naquele momento, foi muito mais um movimento de compra das próprias liberdades (a custos enormes, em muitos casos) do que uma atribuição humanista, promovida pela sensibilidade dos senhores.

Almeida ainda descreve um pouco do que significavam figurativamente os valores que eram intercambiados no estatuto da troca estabelecida: "Em Rio das Contas, a condição mais frequente para o escravo conseguir a sua liberdade era a de acompanhar e servir o seu senhor até a morte dele" (p. 166). Símbolo de uma relação desigual do ponto de vista de benefícios e restrições, a condição para que o indivíduo conseguisse sua libertação era, vergonhosamente, muitas vezes, correspondente a um período de tempo de serviço maior que o da própria vida dos sujeitos que haviam sido escravizados.

\subsection{Referências legais brasileiras}

Após o exame comparativo feito acima, pode-se partir para um olhar mais aprofundado no que concerne à compreensão da problemática da emancipação dentro do marco legal brasileiro. Busca-se, assim, efetuar uma investigação a respeito do sentido desse termo dentro do dispositivo que regulamenta a conduta das pessoas no âmbito do país e que se desdobra em dimensões práticas, quando as leis são aplicadas.

O registro discursivo da legislação remete a um uso específico e inequívoco da linguagem. Isso se dá em virtude da necessidade de que, nesses textos, as conceptualizações sejam mantidas livres de ambiguidades, para o bom funcionamento do sistema no qual os termos circulam. No marco legal brasileiro, a palavra emancipação aparece, entre outros lugares, no Código Civil, no Estatuto da Criança e do Adolescente e no Estatuto da Juventude. Dentre os três textos mencionados, é no primeiro que aparece com maior frequência. 


\subsubsection{Emancipação segundo o Código Civil}

Dito em poucas palavras, Código Civil é o nome dado a um conjunto de leis relativamente próximo dos cidadãos. Seu funcionamento pauta-se pelo funcionamento da Constituição, documento cuja posição hierárquica é mais alta se comparada a ele. No Brasil, sua versão mais atual (lei 10.406) encontra-se em vigor desde 11 de janeiro de 2003 e está dividida em duas partes: a "Parte geral" e a "Parte especial". A primeira comporta três livros (I "Das pessoas", II "Dos bens" e III "Dos fatos jurídicos"), e a segunda, seis (livro I "Dos direitos das obrigações", livro II do "Direito de empresa", livro III "Do direito das coisas", livro IV "Do direito de família", livro V "Do direito das sucessões" e "Livro complementar das disposições finais e transitórias").

O conceito de emancipação presente no texto busca estabelecer as bases sobre as quais um indivíduo obtém independência de seus pais e exerce pessoalmente os atos da vida civil. Embora a personalidade legal comece a partir do nascimento, os menores de dezesseis anos são considerados incapazes de exercer pessoalmente tais atos, assim como os ditos ébrios (os viciados em tóxicos), os excepcionais e os pródigos. É nesse contexto que surge a oposição entre maioridade e menoridade, que classifica os cidadãos segundo essas duas categorias.

Outra denominação legal presente no documento é a incapacidade civil, que define os jovens menores de 18 anos no Brasil. Refere-se ao momento da vida no qual os cidadãos devem sujeitar-se ao chamado "Poder Familiar". Segundo o texto do Código, a menoridade cessa aos 18 anos, quando a pessoa fica habilitada à prática de todos os atos civis (entre 16 e 18 anos há possibilidade de emancipação). Alguns exemplos de tais atos são a cerimônia do casamento, o registro de nascimento, a expedição da carteira de identidade, a matrícula em escola, a inscrição no vestibular e em concursos públicos, o comparecimento às eleições, a homologação do divórcio, entre outros.

O Poder Familiar é uma expressão legal que se refere às atribuições dadas aos pais e tutores. Entre elas, estão as tarefas de criar e educar os filhos, acompanhá-los e protegê-los, dar ou negar consentimento para o seu casamento, nomear tutores (caso os pais encontrem-se impossibilitados de exercer a função), representar os filhos nos atos da vida civil e, também, de "exigir que lhes prestem obediência, respeito e serviços próprios de sua idade e condição" (Parte especial, livro IV, subtít. II, cap. V, seç. II "Do exercício do Poder Familiar", art. VII). Essas atribuições, esboçadas no Código Civil de uma maneira um tanto ampla, procuram regulamentar o período de formação dos cidadãos, para que, entre outras coisas, não sejam feridos os direitos 
básicos da infância. O Estatuto da Criança e do Adolescente traz maior detalhamento a isso, procurando corrigir lacunas deixadas por outras legislações.

Iniciando a análise do texto do Código, no que tange à emancipação pode-se considerar que a ação do Poder Familiar corresponde, em um nível narrativo, à operação transitiva, aquela na qual um sujeito transforma o estado de outro ("os pais" ou "tutores" agindo pelos "filhos", no caso). Tal figura também pode vir a investir a manipulação transitiva, por exemplo, quando o destinador ("os pais") dota o destinatário ("filhos" ou "tutelados") das competências necessárias para a ação.

Segundo o texto do Código, a emancipação legal incorre no fim (extinção) do Poder Familiar. Para os menores, este cessa somente pela concessão dos pais (caso o menor tenha dezesseis anos completos), casamento, colação de grau em curso de ensino superior, "pelo estabelecimento civil ou comercial, ou pela existência de relação de emprego, desde que, em função deles, o menor com dezesseis anos completos tenha economia própria" (Cód. Civil Brasileiro, Parte Geral, Livro I, Título I, Cap. 1, art. 5ㅇ). Em outras palavras, a emancipação ocorre seja pela decisão parental (transformação transitiva) ou pela manifestação de um certo "poder" por parte do menor (transformação reflexiva), que é prova de sua capacidade de exercer os atos civis. Os temas discursivos que se encontram por detrás dessa passagem do texto são, sobretudo, família, formação, relacionamentos e profissão.

Segundo a formulação teórica utilizada na presente dissertação, a modalidade do poder, localizada na etapa da competencialização do programa narrativo, pode ser disposta em quatro posições diferentes, previstas pelo modelo do quadrado semiótico ${ }^{5}$. A partir dessa esquematização, segundo Greimas e Courtés (2012), quatro articulações entre a categoria e o fazer são estabelecidas: poder-fazer (denominada "liberdade" pelos autores), não-poder-fazer (“impotência”), poder-não-fazer ("independência”) e não-poder-não-fazer ("obediência”) (pp. 372-373). Elas representam diferentes formas de manifestação do valor, que enriquecem a capacidade descritiva do instrumental teórico. O quadro abaixo visa a trazer mais visualidade ao que vem sendo exposto.

\footnotetext{
${ }^{5}$ Edward Lopes (2008) efetua uma breve explicação sobre o funcionamento desse modelo, no tópico "O quadrado lógico (semiótico) de Greimas e Rastier" (pp. 317-322).
} 

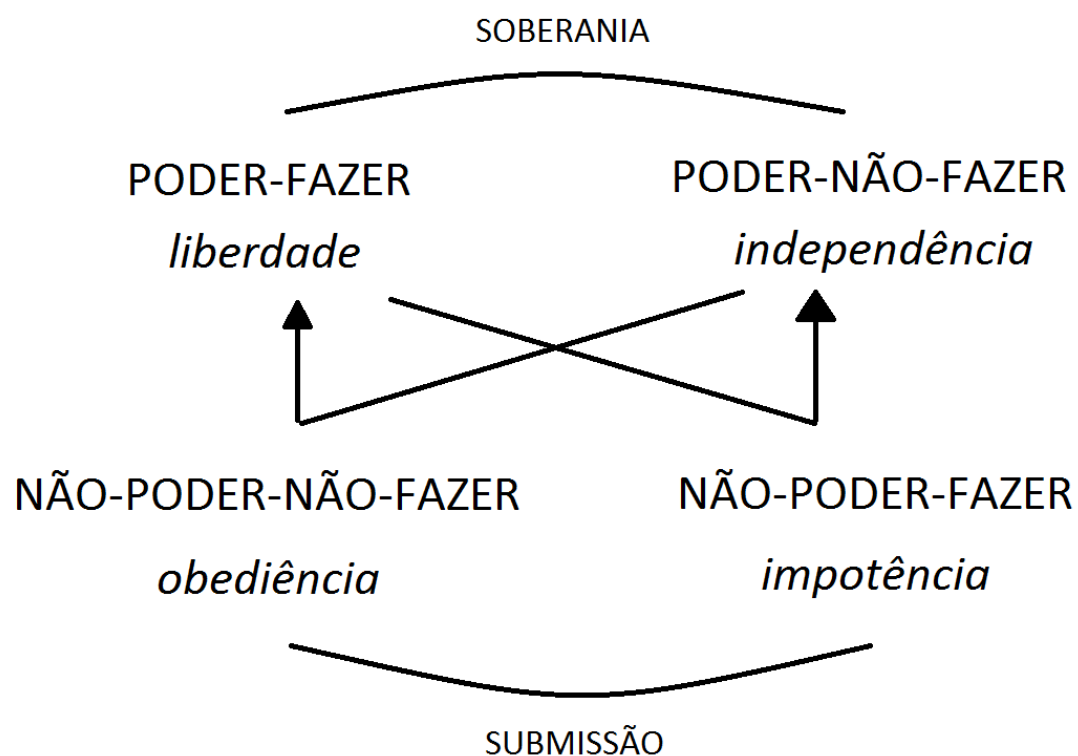

Figura 2 - Quadrado do poder

A lógica do quadrado semiótico ocorre por meio das relações de contrariedade (representada, por exemplo, pela oposição entre liberdade e independência), assim como pelas de contraditoriedade (expressa entre liberdade e impotência, ou entre independência e obediência), ou pelas implicativas (aquelas que se dão entre a obediência e a liberdade, ou entre a impotência e a independência). Há também os eixos, hierarquicamente superiores, que garantem o caráter "solidário e oponível" dos termos contrários (Bertrand, 2003, pp. 175-176). No caso dessa figura, os eixos expostos são o da soberania (superior no esquema) e o da submissão (inferior).

A organização narrativa da incapacidade civil trazida pelo Código remete, sobretudo, a um sujeito que age no eixo da submissão ou, em outras palavras, que está em conjunção com os valores não-poder-não-fazer (obediência) e não-poder-fazer (impotência). As categorias do dever-fazer e do dever-não-fazer, de outra modalidade narrativa, descrevem valores correlacionados a esses, mas vindos do destinador. Após a transformação referida pela emancipação legal, o sujeito pode fazer e não fazer, e isso quer dizer que se encontra atualizado, do ponto de vista narrativo.

Em muitos momentos do texto do Código, identifica-se a presença de uma manipulação narrativa executada por um destinador investido por um ator não coincidente com o do destinatário. Ou seja, há, nesses casos, um fazer-fazer transitivo, com actantes investidos, cada qual, por um ator diferente. Aqui reaparece a configuração narrativa da alforria "romantizada" 
(mencionada na seção anterior). Outra coincidência entre as duas emancipações (emancipação legal e libertação dos escravizados) é que, em ambas as situações, um "tipo" específico de investimento discursivo do destinador é pressuposto para que a emancipação seja legitimada. No primeiro caso, o actante deve ser preferencialmente investido pelos "representantes do Poder Familiar" ou, em sua ausência, pelo "juiz". Na segunda situação, ele deveria ser investido pelos "senhores escravagistas" ou, também, pelos "juízes". No dispositivo legal e na prática social estudados, apenas em circunstâncias especiais a aquisição de liberdade ou independência poderia ser adquirida de modo reflexivo.

A manipulação narrativa do Código Civil também remete à existência de uma manipulação prévia. Nela, o "destinador do destinador", figurativizado pelo ator "Estado", dota o seu destinatário (os "pais" ou "tutores") do valor dever-fazer. Essa primeira manipulação da emancipação, a influência do sistema legal, também se dá de maneira não sincrética, transitiva.

A figura da incapacidade civil, justificativa para a existência do Poder Familiar (e, em sua ausência, para o da Tutela), possui certa proximidade com o que Fontanille e Greimas (1993, p. 114) chamam dissipação e prodigalidade, em um capítulo dedicado ao estudo da avareza. 0 quadrado semiótico utilizado pelos autores para tratar da configuração modal da paixão mencionada (vide as duas figuras reproduzidas a seguir) buscava compor uma linha de raciocínio que associava o fenômeno juntivo (um dos fundamentos da construção do modelo narrativo) à avareza (p. 115). Inicialmente, associou-se a conjunção ao ato de adquirir, e a disjunção ao de gastar (mantendo como contraditórios suas respectivas negações).

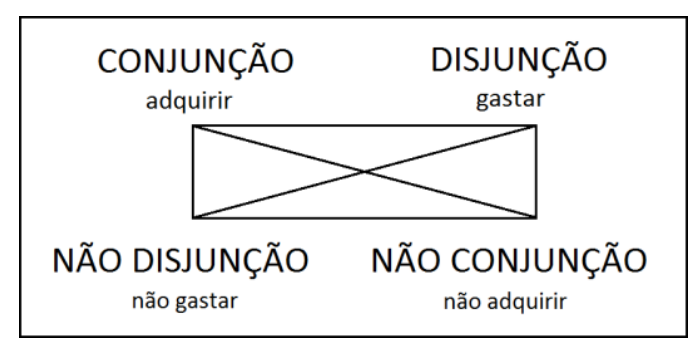

Figura 3 - Quadrado da junção com os termos gastar e adquirir

Em seguida, o que houve no âmbito da mesma obra foi a associação dessas categorias a outras noções, tomadas como fundamentais dentro da construção do sentido, chamadas arquipredicados. Assim, foram estabelecidos os vínculos entre adquirir e tomar, gastar e dar, não gastar e guardar e não adquirir e deixar, como se vê abaixo. 


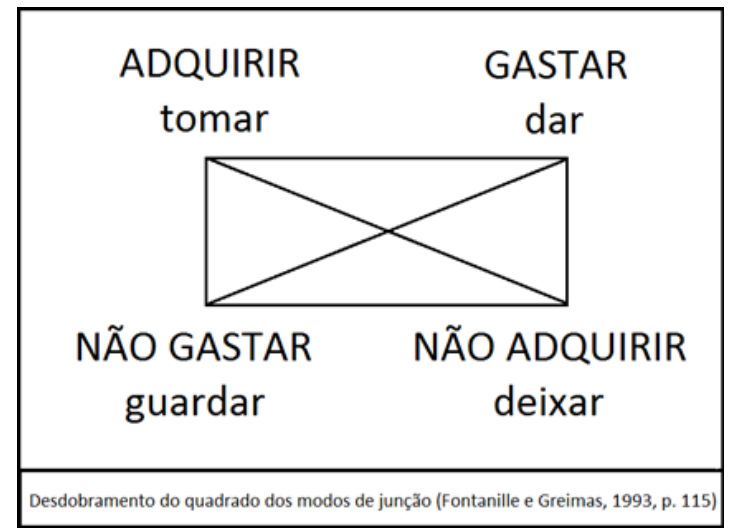

Figura 4 - Arquipredicados do enunciado elementar

O diagrama acima foi desdobrado ainda outra vez dentro da mesma obra, em função do estabelecimento de um modelo organizacional que incluía os julgamentos de excesso e de medida para cada posição prevista no quadrado. Esse procedimento permitiu uma análise mais organizada do funcionamento passional de paixões como a avareza, a avidez, a dissipação, a economia, a prodigalidade, etc., cada uma associada a uma posição do quadrado. Em um esforço pela classificação dos objetos, e para poder utilizar a reflexão feita no âmbito dos estudos da avidez, os autores pontuam que esses variam em suas naturezas, desde os que são acumuláveis e não-consumíveis ("dinheiro" ou "riqueza"), até aqueles nos quais é possível tanto o acúmulo quanto o consumo, tais como os "alimentos" (p. 108). A figura passional da avareza, por exemplo, relaciona-se com objetos acumuláveis e não-consumíveis, sendo a avidez considerada como uma forma mais ampla de desejo imoderado, que abarcaria a primeira, mas que não se restringiria a ela.

A dissipação e a prodigalidade, que interessam ao presente estudo por serem a condição dada ao incapaz no Código Civil, são consideradas formas exageradas do gastar. A realização comedida dessa mesma posição do quadrado corresponderia a uma das acepções de economia ou bem à generosidade, segundo os autores de Semiótica das Paixões. Nesse sentido - e voltando agora ao tema da emancipação legal - tanto os menores quanto os ditos excepcionais, ébrios e pródigos (os sujeitos sociais que compõem o grupo da incapacidade civil), segundo o texto, seriam indivíduos que possuiriam uma propensão a dispersar exageradamente os bens possuídos (objeto de valor, investido por figuras consumíveis ou não consumíveis) e que estariam sujeitos a extinguir ou destruí-los, caso tivessem a condição de simplesmente "fazer o que quisessem". Nesse sentido, e falando agora em termos narrativos, os actantes investidos 
pelo ator "pais ou tutores" são imbuídos da manipulação (de fazer-fazer) ou da transformação (fazer-ser), para garantir que seus destinatários ("os menores, ébrios e pródigos") não se vejam impelidos a perder seus objetos de valor, ou a aniquilá-los por dispersão.

No texto do Código, a palavra emancipação ocorre seis vezes. Na primeira delas, ressalta-se a necessidade de seu registro público (Parte Geral, livro I "Das pessoas", tit I, cap. I, art. 5ㅇ). Na segunda, o documento regulamenta as condições para um indivíduo emancipado exercer funções de empresário (Parte Geral, livro II “Dos bens", tit I, cap. II, art. 976). A terceira ocorrência do termo descreve o momento em que o emancipado pode contestar a validade de ser reconhecido como filho de alguém, caso haja indeterminação a respeito de quem são seus pais (Parte Especial, livro IV “Do direito de família”, subtit II, cap. III, art. 1.614). Na descrição do processo de extinção do poder familiar, encontra-se a quarta aparição da palavra (Parte Especial,

livro IV "Do direito de família", subtit II, cap. V, art. 1.635). A quinta ocorre dentro da regulamentação da prestação de contas (Parte Especial, livro IV "Do direito de família", tit. IV, cap. I, seção VI, art. 1758). Por fim, a sexta aparição do termo regula as condições do fim da tutela, com a maioridade ou a emancipação do menor (Parte Especial, livro IV "Do direito de família", tit. III, cap. I, seção VII, art. 1763).

Verifica-se, assim, que o Código realiza, ao longo de seu desenrolar textual, um percurso que se inicia no aspecto incoativo da emancipação, tratando do registro dos menores e dos emancipados; passa pelo durativo (condições para trabalhar) e chega, por fim, ao terminativo, quando regulamenta as condições necessárias para o encerramento da etapa (o fim da tutela ou da incapacidade civil).

\subsubsection{Estatuto da Criança e do Adolescente e Estatuto da Juventude}

O Estatuto da Criança e do Adolescente, instituído pela lei n. 8.069 de 13 de julho de 1990, é considerado um marco na luta pela defesa dos direitos desse segmento. Seu texto, contudo, pouco menciona a emancipação legal, embora trate com minúcia das questões vinculadas ao direito à liberdade. A única ocorrência da palavra emancipação está no Livro II, na Parte especial (Cap. II "Da justiça da infância e da juventude", Seção II "Do juiz", art. 148, par. único) e diz que a Justiça da Infância e da Juventude é competente para o fim de "conceder a emancipação, nos termos da lei civil, quando faltarem os pais" (mesmo art.). Ou seja, serve para regulamentar as condições de concessão de emancipação na ausência dos pais do menor. 
O Estatuto da Juventude (Lei n. 12.852, de 5 de agosto de 2013), por sua vez, ao tratar da asseguração dos direitos dos jovens, em suas dimensões culturais, esportivas, de saúde, educacionais e de representatividade política, traz mais concretude ao direitos e deveres que já tinham sido conferidos a eles pela Constituição Federal, de maneira menos específica. Foi precedido pela Proposta de Emenda Constitucional 138/03, aprovada em 2010, que incluiu os jovens entre 15 e 29 anos à lista de prioridades do Estado em direitos como saúde, alimentação, educação, lazer, profissionalização e cultura. A principal função desse texto é assegurar que se cumpram os direitos básicos dos jovens, estabelecendo e organizando os órgãos públicos e a sociedade em geral para a realização de tal função. Além disso, o Estatuto organiza as bases para a criação do Sistema Nacional de Juventude (SINAJUVE), o órgão público responsável pela implementação e fiscalização das propostas contidas no documento.

\footnotetext{
"Art. 20 O disposto nesta Lei e as políticas públicas de juventude são regidos pelos seguintes princípios:

I - promoção da autonomia e emancipação dos jovens;

II - valorização e promoção da participação social e política, de forma direta e por meio de suas representações;

III - promoção da criatividade e da participação no desenvolvimento do País;

IV - reconhecimento do jovem como sujeito de direitos universais, geracionais e singulares;

V - promoção do bem-estar, da experimentação e do desenvolvimento integral do jovem;

$\mathrm{VI}$ - respeito à identidade e à diversidade individual e coletiva da juventude;

VII - promoção da vida segura, da cultura da paz, da solidariedade e da não discriminação;

e

VIII - valorização do diálogo e convívio do jovem com as demais gerações." (Estatuto da Juventude, tít. I, cap. I, seç. I, art. 2o, grifo nosso)
}

Logo no início da Seção I do documento, que traça os princípios que o regulam, no artigo 2 (acima transcrito), encontram-se as expressões "autonomia e emancipação dos jovens". A proposta é que a promoção desses direitos seja regulada e pormenorizada pelo Estatuto. As palavras, no caso, referem-se às acepções do senso comum, não fazendo qualquer referência à 
emancipação legal, como regulamentada no Código Civil. Como explicita o Parágrafo Único, ao final da Seção I, trata-se de dois conceitos distintos.

\footnotetext{
“Parágrafo único. A emancipação dos jovens a que se refere o inciso I do caput refere-se à trajetória de inclusão, liberdade e participação do jovem na vida em sociedade, e não ao instituto da emancipação disciplinado pela Lei n. 10.406, de 10 de janeiro de 2002 - Código Civil." (Estatuto da Juventude, Seção I "Dos princípios”, par. único)
}

O trecho acima faz menção à "inclusão (...) do jovem na vida em sociedade", o que, de certo modo, sugere o reconhecimento de uma exclusão que haveria do segmento no meio. No texto, há muitas referências ao direito à participação do jovem nas esferas sociais e políticas. Sob uma ótica narrativa, pode-se afirmar que esse tema remete a uma conjunção do sujeito com valores do eixo da soberania (poder-fazer ou poder-não-fazer). Sendo o direito de participar garantido e concedido por um destinador investido por um ator institucional ("SINAJUVE"), e que não coincide com o ator do sujeito ("jovem”), trata-se, pois, de uma manipulação transitiva. O investimento discursivo da ação, nesse caso, é o ato de participar (ou o sentir-se parte) da sociedade. Sua concretização depende da vontade (querer) ou do senso de responsabilidade (dever) do indivíduo em questão de tomar parte nos processos em pauta.

Ainda na temática da participação, a palavra "valorização" (presente no item II do 2oㅡ artigo, transcrito acima) corresponde a um apelo feito aos cidadãos e às instâncias competentes a "avaliar positivamente" e a ser receptivos à capacidade dos jovens de realizar os processos políticos e de atuar nos mecanismos de decisão sociais. Tal ação é uma maneira de predispor e incentivar os órgãos públicos a promover a presença do segmento nesses âmbitos. Narrativamente falando, o que está em jogo aqui é o papel actancial de destinador, que age no sentido de garantir que o antiprograma ("a ausência de participação política dos jovens") não impeça o programa do sujeito ("a participação").

\subsubsection{Identidade e diversidade}

Seguindo com a análise da seção I do Estatuto, as expressões que se referem ao "respeito à identidade e à diversidade individual e coletiva da juventude" (Estatuto da 
Juventude, tít. I, cap. I, seç. I, art. 2º, grifo nosso) chamam atenção, pois os conceitos destacados remetem a fenômenos de significação complementares e profundos. Ao mesmo tempo em que a construção da ideia de "eu" parece dar-se de modo reflexivo, com os indivíduos reconhecendo a si mesmos, ela remete às similaridades e diferenças que mantêm quanto aos outros membros de uma mesma comunidade.

A noção de identidade parece ganhar uma nova perspectiva quando vista segundo as possibilidades descritivas das modalidades da etapa da potencialização do percurso narrativo (aderir e assumir), tais como propostas por Fontanille e Zilberberg (2001, p. 256). Nesse sentido, supõe-se que há, na construção da ideia de "eu", uma adesão (exógena), que traz ao sujeito o senso de pertencimento, a partir da imagem que ele faz dos outros e que estes fazem dele. Nesse sentido, a diversidade parece remeter ao movimento que o indivíduo realiza quando deseja delimitar e compreender sua participação no mundo. A assunção (endógena), outro processo pelo qual a imagem própria do sujeito se veria constituída, por sua vez, seria algo como uma disposição (ou não) de ocupar uma determinação actancial interna.

Ao inscrever-se na etapa da potencialização, que é quando ocorre a consolidação ou a dissipação de uma crença (no caso, reflexiva), a construção de identidade relaciona-se, entre outros temas do nível discursivo, à autoconfiança. Pode-se considerar que esse último termo corresponde a uma peça-chave no estabelecimento dos jovens na vida em sociedade. Além disso, é interessante ressaltar que a construção de identidade parece estabelecer-se tanto por mecanismos discursivos, como por vias afetivas e sensoriais.

Fontanille e Greimas (1993, p. 169), durante análise dirigida à série de paixões "estimaadmiração-veneração", apontam que estas remetem a duas instâncias, o observador apaixonado e o sujeito-objeto, e que elas passam por intensificações e atenuações de significação a cada uma das etapas mencionadas acima. Assim, a estima é uma forma na qual o sujeito-observador está mais presente e o sujeito-objeto menos ativo. A veneração, em oposição, seria paixão configurada por uma maior presença do outro, atenuado o papel do observador. Segundo os autores, o lugar de articulação dessa intensidade se encontraria na etapa pré-semiótica, "onde a identidade de um é ainda instável e depende da identidade de outrem; uma identidade interactancial deveria ser partilhada, e cada identidade individual se estabeleceria em detrimento das demais" (p. 169).

A conceituação proposta pelos autores, que situa o lugar da estima mais próximo do sujeito do que do objeto, parece, à uma primeira vista, confirmar a tese de que a aquisição de autoestima está relacionada à construção de identidade por parte dos jovens. Por outro lado, 
não é possível atribuir a constituição da identidade unicamente a uma das paixões mencionadas acima, uma vez que o "jogo de ativação" entre sujeito e objeto varia nas diferentes manifestações que tratam desse tema.

\subsubsection{Discriminação}

A discriminação é mencionada na seção I do Estatuto da Juventude, quando o texto fala da necessidade de promoção de uma cultura livre de tal julgamento. Com essa asserção, é reconhecida a presença do preconceito no âmbito social brasileiro, mesmo que de modo implícito. Em termos narrativos, o que está em questão em qualquer passagem textual que mencione a discriminação é uma sanção (a etapa final do percurso gerativo de sentido). Contudo, como lembra o texto do Estatuto, o término de um PN não significa apenas o fim de um percurso, mas também o início de outros que podem vir a ocorrer na sequência.

Nas manifestações discursivas da discriminação, frequentemente há o que se denomina, no nível narrativo, uma sanção cognitiva negativa, emitida sobre o destinatário-julgado, feita com base nas modalidades epistêmicas (Greimas e Courtés, 2012, p. 427). Ela "sobredetermina" um enunciado de estado, com base nas quatro articulações possíveis da categoria epistêmica (crer-ser, crer-não-ser, não-crer-ser, não-crer-não-ser). Em outras palavras, há um julgamento pejorativo com base nas características de um dado ser, a partir de um sistema de referências próprio.

O narrador do texto do documento posiciona-se contra as discriminações, sem dar ao tema muita pormenorização, em um primeiro momento. Na Seção IV, transcrita abaixo, contudo, mais especificação é dada a isso.

“O jovem tem direito à diversidade e à igualdade de direitos e de oportunidades e não será discriminado por motivo de:

I - etnia, raça, cor da pele, cultura, origem, idade e sexo;

II - orientação sexual, idioma ou religião;

III - opinião, deficiência e condição social ou econômica." (Estatuto da Juventude, Seção IV, art. 17) 
Ao tratar a não discriminação em termos de igualdade de direitos e de oportunidades, vê-se que, segundo conceitos do nível narrativo, o documento não está se referindo apenas a uma sanção, mas também a uma manipulação. O uso da expressão “igualdade de (...) oportunidades", ressalta o caráter de fazer-fazer da passagem, pois se refere às chances que os indivíduos têm de agir. Nesse sentido, o texto do Estatuto não apenas avalia negativamente as ações preconceituosas, como procura também estabelecer uma regulamentação que leve a uma sociedade mais igualitária no futuro.

Outro ponto interessante de ser mencionado, em meio à grande variedade de temas e discussões que o documento levanta, é a "valorização do diálogo e convívio do jovem com as demais gerações", mencionada também na Seção I do documento. Embora não haja posterior desenvolvimento do assunto no desenrolar do texto, a presença de uma preocupação com o convívio humano e intergeracional destaca-se tematicamente dos outros componentes discursivos encontrados. Essa parte do Estatuto remete a uma postura de valorização do relacionamento humano em todas suas idades. Quando se menciona, mais adiante, que "o jovem tem direito à cultura (...) e à memória social" (Seção IV "Do direito à cultura", art. 21), ressalta-se não apenas a importância das relações entre indivíduos de diferentes gerações, mas também, a das interações sociais travadas ao longo da história.

\subsubsection{Perfil dos documentos}

Pode-se inferir que o Código Civil trata de emancipação como um dispositivo legal que regulamenta a transição de status dos cidadãos da menoridade à maioridade antes da chegada dos dezoito anos, estabelecendo algumas regras para isso. Outros conceitos vindos do universo jurídico, dentre eles, por exemplo, o de Poder Familiar (cuja definição e atribuições se dão no próprio documento), atuam de maneira complementar na abordagem do tema.

No nível narrativo, além de haver menção a enunciados de transformação ("período da Tutela"), há referências à etapa da manipulação ("emancipação"). No primeiro caso, o sujeito operador ("pais" ou "tutores"), diferenciado do sujeito de estado (os "menores"), que vivencia a alteração de seu estatuto juntivo, assegura a conjunção do último quanto aos objetos de valor necessários à vida (os "direitos básicos"). Já no segundo, há um destinador ("pais" ou "juízes") que transmite a seu destinatário (os "menores") os valores modais necessários à preservação 
dos bens culturais e materiais. Anteriormente a isso, o sujeito, actorializado pelos indivíduos com menos de 18 anos (classificados sob o rótulo da incapacidade civil), é considerado inábil ${ }^{6}$ para a ação ("administrar ou sustentar o patrimônio que detêm"). As modalidades deônticas podem ser consideradas como as principais categorias utilizadas pelo texto em seu esforço por regulamentar as práticas sociais relacionadas ao tema estudado.

O Estatuto da Juventude, por sua vez, aborda a emancipação de uma maneira complexa e discursivamente mais rica. Esse documento não se refere apenas ao dispositivo legal que regula a transição da menoridade à maioridade, mas à passagem que marca a inserção global dos indivíduos jovens na vida adulta. O texto vale-se do conceito da palavra usado no senso comum. Dentre as principais noções tratadas, está a defesa do direito à participação política dos jovens como uma atitude voluntária (baseada no querer), justificada pela asseveração de sua capacidade de tomar parte nesses processos. O texto também discute a problemática da identidade e da diversidade, vendo-as como valores importantes para o segmento. Isso se dá com base no reconhecimento de que o jovem vive uma fase que ainda carece de cuidados para que possa chegar a reconhecer-se como um sujeito social.

Além dos assuntos mencionados acima, o tema discriminação é abordado pelas discussões do Estatuto, não apenas como ameaça à constituição da autoimagem dos indivíduos, mas também como um possível mecanismo de impedimento à realização dos atos da vida civil, tais como o ingresso em uma universidade ou no mercado de trabalho. Após isso, é ressaltado o valor do convívio humano para a formação dos indivíduos (tomada em suas dimensões intergeracional e histórica).

Por fim, a regulamentação e a descrição dos termos e condições necessárias à criação do SINAJUVE fazem ver que o reconhecimento e a asseguração do cumprimento dos direitos dos jovens ainda não são uma realidade no país. Esse sistema vem desempenhar o que, no nível narrativo, denomina-se o papel do destinador, transmitindo o valor de dever-fazer ao destinatário ("instituições públicas e privadas relacionadas à juventude"). Contudo, essa manipulação se dá em um nível de "sobremanipulação", pois, supõe-se, dará sequência ao movimento de fazer-fazer em outro PN. Nesse segundo programa, o destinador (investido pelo mesmo ator do destinatário do programa anterior, "instituições relacionadas à juventude") dotará o destinatário (os "jovens brasileiros") das motivações e capacidades necessárias à emancipação.

\footnotetext{
${ }^{6}$ Barros (2002, p. 53) sugere o uso do termo "inabilidade" para designar a modalidade do não-saber-nãofazer.
} 


\section{Fidúcia em "Sundjata, ou A epopeia mandinga"}

Este primeiro capítulo dedica-se à análise das relações existentes entre emancipação (entendida como transformação narrativa na qual ocorre doação ou aquisição de competências modais relacionadas ao poder-fazer e ao poder-não-fazer) e a modalidade epistêmica, a partir de um estudo de caso. Baseia-se na compreensão de que essa categoria que rege a crença do sujeito também atua no vínculo que há entre destinador e destinatário, na etapa da manipulação. Assim, trata do contrato fiduciário entre os dois actantes acima mencionados, anteriormente à competencialização. Para tal, são verificados os modos pelos quais a modalidade veridictória (que articula a relação entre os esquemas da manifestação e da imanência) influencia o movimento "ondulatório" do crer, sendo que este rege o êxito ou o fracasso da manipulação. Também dedica especial atenção às relações que podem ser estabelecidas entre as etapas da potencialização ${ }^{7}$ e da virtualização. Esta última é a passagem que marca a mudança no estatuto de um sujeito de estado disjunto dos objetos e valores e que se motiva a entrar em conjunção com eles.

O texto escolhido para esta análise é o romance épico Soundjata ou L'Épopée Mandingue, de Djibril Tamsir Niane (1960). Na tradução ao português (1982), a obra chama-se Sundjata, ou $A$ epopeia mandinga ${ }^{8}$. Ela foi selecionada pelo rendimento analítico de suas passagens no que tange à constituição da relação fiduciária.

O principal ator discursivo que recobre o papel de destinatário e de sujeito do fazer na épica é o herói Sundjata, que também responde pelos nomes de Mari Djata ou Sogolon Djata. De maneira paralela, os atores que mais investem o papel de destinador nessa delimitação textual são "Maghan Kon Fatta" e "Sogolon Kedju" (respectivamente, o pai e a mãe do primeiro). Nosso corpus restringe-se aos sete primeiros capítulos do livro (Niane, 1982, pp. 11 - 47). Tal recorte visa a um exame da problemática acima mencionada no momento em que aparece com mais vigor na narrativa.

\footnotetext{
${ }^{7}$ Fontanille e Zilberberg traçam um resumo do que são as etapas do esquema da presença: realização, potencialização, virtualização e atualização. A análise é feita com base nessa proposta (2001, p. 256, verbete "modalidade").

${ }^{8} \mathrm{Na}$ tradução ao português, a grafia do nome do protagonista foi adaptada para Sundjata.
} 


\subsection{Sinopse da trama}

A narrativa inicia-se com uma cena cotidiana. No momento, o rei Narê Maghan e seu filho Dankaran Tuman encontram-se debaixo da copa de uma frondosa paineira, a contemplar o horizonte, quando ocorre a chegada inesperada de um caçador estrangeiro a Nianiba. Vindo de Sangaran, país tributário do Mandinga, e tendo abatido uma caça perto dos muros reais ${ }^{9}, 0$ personagem vê-se impelido a compartilhar parte dela com Maghan.

Vista positivamente pelo soberano (que, segundo o griô ${ }^{10}$ Nhankuman Dua, "amava os homens corretos", 1982, p. 17), essa ação é o primeiro indício de que o caçador viria a representar uma forte fonte de influência para Maghan e, indiretamente, para seu reino. Antes de deixar a residência real, contudo, o forasteiro realiza importantes predições a respeito do futuro da linhagem do governante.

Com a ida do caçador-adivinho, a narrativa prossegue com o cumprimento de algumas das suas profecias: aparecem em Niani dois caçadores e uma jovem mulher corcunda. Eles relatam a história de como acabaram chegando até lá. Durante o diálogo, os personagens contam sobre o momento no qual decidiram candidatar-se para enfrentar o temido búfalo de Do, fera que vinha assolando o reino e que nenhum caçador até então havia podido vencer. No caminho para encontrá-la, após dar um pedaço de carne salgada a uma velha faminta, descobrem que a generosidade deles havia sido também a sua sorte, pois a senhora era o próprio animal em forma humana e, pela boa ação que haviam realizado, Ihes ensina a estratégia correta para a vitória sobre a criatura (ocorre aí a doação de um saber-fazer, segundo a formulação do nível narrativo).

Conforme as orientações da senhora, os caçadores realizam o feito de caçar o búfalo, para depois ganhar a recompensa prometida pelo Rei de Do: o dote de Sogolon Kedju, que era a jovem que os acompanhava na chegada ao Niani. Não tendo podido nenhum dos dois possuíla, eis que a recomendavam a Narê Maghan. Segundo as profecias do caçador-adivinho, ela seria a mulher que o soberano deveria desposar.

O casamento efetua-se (como previsto) e os dois têm um filho de nome Sundjata, que é celebrado por todo o povo como o futuro herdeiro do Mandinga. Apenas Sassuma Beretê, a primeira mulher do soberano, não se sentia satisfeita com a situação. Ofuscada pelo

\footnotetext{
${ }^{9}$ Segundo os bons costumes da época, quando isso ocorria, era um dever dos caçadores levar uma parcela do animal abatido ao rei em cujas proximidades a caça havia ocorrido (Niane, 1982, p. 17).

${ }^{10}$ Griot (fr.): por excelência, um portador da sabedoria a respeito da história e das demais ciências, figura tradicional das sociedades africanas.
} 
aparecimento de Sogolon, tinha também medo de que seu filho Dankaran Tuman, primeiro descendente real, perdesse direito ao trono, com a chegada do novo irmão.

Após o nascimento e durante a sua infância, Sundjata tinha uma deficiência nas pernas que o impedia de se levantar do chão. Arrastava-se pelo assoalho da casa de sua mãe, sendo uma criança "rústica", além disso, em outros aspectos também (rudeza no trato com outras crianças e gulodice). De modo geral, os traços de sua personalidade, quando criança, possuem uma valência tensiva similar, pois são intensos e adeptos do excesso, esteja ele investido na figura da força física ou naquela do apetite (Zilberberg, 2011, p. 81).

Com a condição debilitada do menino e o falecimento do soberano, Sassuma faz movimentações na sociedade para fazer de seu filho, Dankaran, o rei do Mandinga. Entre as ações que realiza para tanto estão desmoralizações e humilhações a Sogolon Kedju, e, em especial, uma intriga feita na comunidade para impedir o acesso de Sundjata ao trono depois do falecimento de Narê Maghan. Antes de partir, porém, o soberano havia escolhido o filho de Sogolon como sucessor. Na mesma ocasião, havia nomeado o filho de Nhankuman Dua (seu griô pessoal), chamado Balla Fassekê, como griô de Sundjata.

Um dia, profundamente magoada com a situação à qual havia sido relegada, Kedju chora diante das humilhações constantes de Sassuma e da impossibilidade de que seu filho pudesse Ihe colher folhas de baobá, por não poder caminhar. Nesse turning point narrativo, Sundjata desperta, manda trazer da oficina do ferreiro da vila uma enorme barra de ferro e, apoiando-se na peça, ergue-se do chão ao mesmo tempo em que a entorta. Após essa passagem, endireitamse as suas pernas de modo definitivo. Traz, então, à frente da casa de sua mãe não só as folhas, mas toda a grande árvore baobá, que arrancara do chão com sua força descomunal.

\subsection{Narê Maghan}

Sintetizada a parte pertinente da trama, inicia-se o trabalho analítico com a recuperação do contrato fiduciário que há entre destinador e destinatário na história. O segundo desses actantes, em um primeiro momento, encontra-se recoberto pelo ator discursivo "Maghan Kon Fatta". O vínculo epistêmico que trava no início da narrativa dá-se durante a etapa da manipulação, realizada pelo destinador investido pelo "caçador de Sangaran". As palavras do último ator ganham mais e mais peso conforme a narrativa se desenvolve, por meio de alguns mecanismos que convêm identificar.

Inicialmente, o elemento que confere uma boa impressão do adivinho ao rei é seu já mencionado "apreço pelos homens justos", corroborado pelo ato generoso do forasteiro de trazer-Ihe uma parcela da caça que havia abatido. Em seguida, no desenrolar da narrativa, uma 
fala revela aos leitores outra chave para a constituição do vínculo do soberano com o caçador. Essa se encontra expressa na frase: "Tu, que vens do Sangaran, país dos favoritos de Kondolon Ni Sanê, tu que tiveste certamente um mestre cheio de Ciência (...)"11 (1982, p. 17). Em nota de rodapé, o autor explica quem são Kondolon e Sané, divindades da caça que guardam o cerrado e a floresta, símbolos da união e da amizade (pp. 14-15). Nesse momento, a história remete, no nível narrativo, a uma aquisição de confiança ${ }^{12}$, pautada na sanção positiva realizada pelo destinador-julgador ("Narê Maghan") sobre o destinatário-julgado ("as divindades e o caçador"). Esses mestres ou deuses, vindos do passado, reforçam o movimento de crença do rei. A confiança do soberano no forasteiro vem da filiação do último a esses seres que, reconhecidamente, "sabem fazer bem", e que inscrevem no homem de Sangaran, de antemão, a imagem de pessoa "provavelmente justa". Em termos narrativos, o fazer avaliativo do destinador-julgador atribui o valor de não-dever-não-ser (probabilidade conjugada à veridicção) às palavras do destinatário-julgado. No nível discursivo, os temas generosidade e honestidade são reconhecidos e apreciados pelo ator "Maghan" e fazem parte da construção de imagem do adivinho.

Ao mesmo tempo em que a confiança entre Narê Maghan e o caçador se vê fortalecida pela noção de linhagem, há também um elemento facilitador dessa construção que decorre do pertencimento do segundo a um território específico. Essa influência se expressa no termo "país" (pays, no original em francês), e dá um caráter espacial à imagem que o rei faz do forasteiro. Progressivamente, as palavras do caçador ganham peso e são consideradas mais verdadeiras pelo rei e por seu griô.

Além dos três fatores relatados, há ainda o trecho no qual Nhankuman Dua faz Narê Maghan notar que o caçador é canhoto. Nesse momento do texto, a voz narrativa informa os leitores a respeito de um conhecimento tradicional. Segundo ela, a mão esquerda, embora seja considerada a main du mal, identifica os melhores adivinhos. Isso corrobora a boa reputação do caçador como adivinho e, consequentemente, fortalece sua imagem de portador do "dizerverdadeiro". A associação de um traço da natureza humana (ser canhoto) a um grupo social (os melhores adivinhos) traz mais certeza para o rei. Esse saber veio conhecimento tradicional, obtida pelo personagem em momento anterior à temporalidade do narrado.

Há, então, na caracterização narrativa da confiança entre destinatário-manipulado e destinador-manipulador, um crer-dever-ser que se estabelece por alguns mecanismos: (1) pelo

\footnotetext{
${ }^{11}$ No francês, "Toi qui viens du Sangaran, pays des favoris de Kondolon ni Sané, Toi qui as eu sans doute un maître plein de Science" (Niane, 1960, p. 18).

${ }^{12}$ Fontanille e Zilberberg (2001, p. 265) reconhecem uma dupla natureza no universo fiduciário, o sistema da crença (sujeito-objeto) e o da confiança (sujeito-sujeito).
} 
julgamento positivo da conduta do sujeito; (2) pela linhagem ou pela sua filiação a "destinadores antecessores", cuja reputação também era positiva; (3) pela noção de pertencimento a um território, que representava uma boa origem, e, por fim, (4) pelo reconhecimento de uma competência (saber-fazer), advindo de um conhecimento sobre um traço corporal do personagem.

A profunda confiança de Narê Maghan na honestidade e nas habilidades premonitórias do forasteiro erige-se sobre uma base sólida, bem assentada. Nessa manipulação narrativa, o destinador é investido pelo ator "caçador" e o destinatário pelo "rei", respaldados por uma vigorosa modalidade do crer. Um pouco adiante em "A epopeia mandinga", há uma alteração na distribuição discursiva dos papéis actanciais, pois o soberano sai do papel de destinatário para ocupar então o lugar de destinador de seu filho, Sundjata. A confiança acumulada no primeiro PN (entre "o rei" e "o estrangeiro") ainda ressoará como reforço positivo ao contrato fiduciário que se estabelece no segundo programa de manipulação (entre "rei" e "filho"), resistindo sob a forma de memória epistêmica, do programa de manipulação inicial ao subsequente.

Greimas e Courtés (2012) afirmam que os fenômenos ligados à modalidade epistêmica transitam de um termo a outro do quadrado variando em graus de certeza (crer-ser) ou incerteza (não-crer-ser) e dispõem as categorias dessa modalidade em um quadro como o reproduzido abaixo.

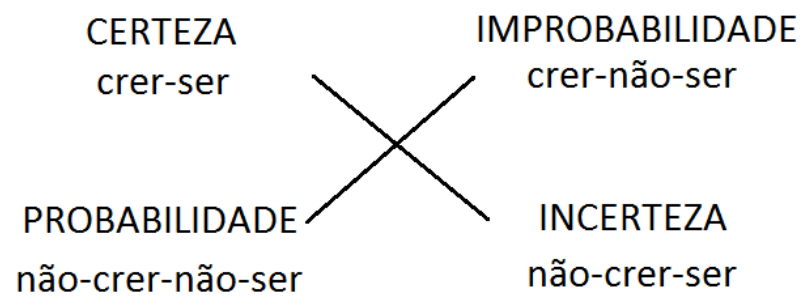

Figura 5 - Modalidades epistêmicas para Greimas e Courtés (2012, p. 172)

Algum aprofundamento a esse instrumental teórico encontra-se em Tensão $e$ Significação (Fontanille e Zilberberg, 2001, pp. 264 - 268). Os autores propõem uma distinção inicial na fidúcia, separando o crer em um objeto (crença) do crer intersubjetivo (confiança). Ao tomar como verdadeiras as palavras do caçador, o rei Maghan julga as palavras do adivinho. Ele estaria fazendo uso, nesse momento, segundo a nomenclatura proposta pelos autores, da crença, em um posicionamento que se pode identificar com a "certeza", pois afirma uma veracidade do objeto. Não há, contudo, como afirmar que não existam traços de confiança 
intersubjetiva no mesmo trecho, uma vez que, como se viu, a imagem do ator "adivinho" desempenha papel fundamental para a crença em suas palavras. Há aqui, então, um registro misto entre os dois modos de crer mencionados acima.

Não é só o forasteiro de Sangaran que influencia o rei. O ator "Nhankuman Dua", que também investe funções referentes ao papel temático de destinador de Narê Maghan, é de importância vital para a tomada de decisões do soberano. Antes de partir para a análise da ação do personagem Dua, porém, faz-se pertinente uma reflexão a respeito da abordagem usual da historiografia, que se encontra na introdução do livro Sundjata, ou A epopeia mandinga, e que serve como pano de fundo para a compreensão do papel do griô nas sociedades da África.

Niane (1982) afirma que "O ocidente ensinou-nos, infelizmente, a desprezar as fontes orais em matéria de História sendo, por isso, considerado como sem fundamento tudo o que não esteja escrito, o preto no branco" (p. 7). Contrapondo-se à tradição historiográfica ocidental (que dá valor, sobretudo, ao documento escrito, ou à história oficial, em detrimento de outras fontes de saber), o autor sustenta e reforça o papel fundamental dos tradicionalistas para a história das aldeias. E esse apreço pelos discursos vindos da tradição oral não se expressa apenas no plano do conteúdo no romance. É visível, ao longo de todo o texto de "A epopeia mandinga", que a figura de Djibril Tamsir Niane mescla-se à fala de griôs e das comunidades nas quais encontra a fonte para seus escritos. São os sábios e anciões da região de Fadama e Siguiri, na Guiné, que "falam" também pela escrita dele. Nesse sentido, pode-se afirmar que há algo como uma "autoria compartilhada" na obra, pois a constituição do enunciador desse texto se dá por meio de um processo complexo.

Posto isto, constata-se que, ao mesmo tempo em que há uma relação fiduciária extremamente vigorosa entre os actantes investidos pelos personagens Narê Maghan e Nhankuman, o enunciador do texto também guarda uma forte confiança em seus "destinadores" ("os griôs da região"). Essa relação encontra-se articulada com a modalidade do saber. Manter viva a história é um proceder típico das sociedades pautadas pela tradição oral e um elemento discursivo presente nas duas manipulações narrativas tratadas acima. Uma delas é do nível da enunciação, representada pela figura de Djibril Tamsir Niane (destinatário) diante da comunidade dos sábios da Guiné (destinador). A outra é do plano do enunciado, a que ocorre entre o rei Maghan (destinatário) e seu griô pessoal (destinador).

Apresenta-se, assim, o fato de que ambas as aproximações entre destinador e destinatário reportam-se a uma noção específica do acreditável (uma proposta de encaminhamento semiótico para esse conceito é o "crer" da doxa, segundo Zilberberg, 2011, p. 243) e criam uma maneira de instauração de certeza no sujeito, pautada não em referências concretas, objetivas, escritas e documentadas, mas em textos orais e mais marcados 
enunciativamente, mais próximos, talvez, à concepção da antiga retórica, que via na construção do ethos do orador digno de fé um elemento fundamental da instauração do efeito de certeza de um texto (Maingueneau, 2008, p. 13).

Ainda tratando dessa mesma questão, adicionando um comentário de cunho historiográfico, Meihy (1996), em seu Manual de História Oral, afirma que, mesmo dentro do âmbito dos estudos acadêmicos, "dúvidas comuns como a 'representatividade' dos testemunhos [orais], o 'alcance histórico' das impressões e a 'relatividade' dos casos narrados têm perdido a força na medida em que as virtudes e a popularidade da história oral passam a integrar preferências indiscutíveis e a ganhar adeptos de peso" (p. 10)

Retornando à análise da relação de confiança entre Dua e Maghan, reforça-se a tese de que o primeiro atua como uma espécie de auxiliar cognitivo do segundo, atuando por meio do que se denomina manipulação pelo saber. Nesse sentido, a ação do destinador ("griô") visa a auxiliar o destinatário ("rei") a inferir, a partir da negação ou da confirmação do parecer, o ser (ou o não-ser, a depender do caso). Greimas e Courtés (2012) definem o fazer persuasivo da categoria do ser como "um fazer cognitivo, que visa a levar o enunciatário a atribuir ao processo semiótico ou a qualquer de seus segmentos - que só pode ser por ele recebido como uma manifestação - o estatuto de imanência" (p. 368).

Em um primeiro momento, Nhankuman aponta para o caçador e faz o rei ver que o forasteiro é canhoto, o que dá ao seu amo elementos para que dele construa uma imagem positiva, como visto acima. Outro extrato textual que ilustra a influência de Dua sobre o soberano encontra-se na página 33 da épica. Nele, estando o rei incerto quanto ao destino do filho, abalado pelo fato de que o menino, aos três anos, ainda não havia dado seus primeiros passos, o griô não cessa de lembrar as palavras do caçador que previam o futuro glorioso do rebento de Sogolon. Atua, nesse momento, como "refresco" à memória de Maghan, trazendo conhecimentos anteriores ao presente e enunciando, uma vez mais, o que tinha sido dito. A repetição estende a fala já proferida em uma nova dimensão da temporalidade. Trata-se de uma espécie de reduplicação das ideias do adivinho. Nhankuman, por meio de ações que buscam estimular a memória do rei, presentifica o passado e permite que determinados elementos sejam levados em conta durante a avaliação de um elemento. Sua intervenção é fundamental para a tomada de decisão do soberano.

O prolongamento da fala do caçador-adivinho em outras cenas discursivas pode ser entendido como uma decorrência da alta tonicidade de suas palavras. Por sua profundidade e abrangência, as afirmações premonitórias do forasteiro demandaram uma temporalidade maior do que a da cena na qual foram proferidas para que pudessem ser assimiladas pelo rei. Como 
não se repetiriam por si mesmas, a solução encontrada por Dua as reproduz em outras oportunidades ao longo da narrativa.

Ainda tratando da influência de Nhankuman sobre o rei, outra característica que se depreende em sua persuasão é o ato de trazer certos elementos sensíveis e perceptíveis para a apreciação do soberano. Para fazer com que Maghan tenha uma visão específica a respeito das coisas do mundo, e não qualquer interpretação sobre elas, o griô ressalta, nas cenas que divide com ele, determinados aspectos, procurando fazer com que a interpretação de seu amo seja ativada em uma direção específica.

A intervenção de Dua é suave, aparentemente desinteressada. Sob certa ótica, o sujeito que se encontra por trás desse ator aproxima-se de um não-fazer-fazer (não intervenção), segundo o termo proposto por Greimas e Courtés (p. 301). Ao inserir, "como quem não quer nada", elementos sensíveis para refrescar a capacidade de observação do destinatário, o ator age como um destinador, que transmite o saber apresentando objetos visíveis, audíveis e táteis, ao mesmo tempo em que preserva a face do ator "Narê Maghan", "dona de suas ações" e com liberdade de escolha ${ }^{13}$. Pode-se afirmar que as principais modalidades com as quais a manipulação do destinador "Nhankuman" atua são aquelas relacionadas ao fazer-saber e ao fazer-poder, não influenciando o rei no que tange às modalidades do querer e do dever.

\subsubsection{0 rei e seu filho}

A forte relação existente entre os personagens Narê Maghan e seu filho, Sundjata, permite afirmar que a problemática da definição do substituto ao trono real ocupa lugar de destaque na história. A passagem textual na qual isso ocorre proporciona um bom ponto de observação sobre o que se denomina, em semiótica narrativa, estabelecimento de contrato fiduciário. Para iniciar o exame dos movimentos que levam o rei a confiar plenamente em Mari Djata, faz-se necessário evocar a infância do rapaz, na qual ele não podia caminhar. Ao testemunhar a demora do garoto em aprender a andar, a confiança de Maghan nele passa por um período de decréscimo. O que se configurava, até então, como um contrato bem estabelecido (o crer nas capacidades do menino de desempenhar a sucessão real) encontra um questionamento, decorrente, sobretudo, da lentidão relativa que seu desenvolvimento aparentava ter para o pai.

13 Greimas e Courtés definem o "código da soberania" como a somatória do poder-fazer e do poder-nãofazer dentro do subcódigo de honra que a manipulação põe em jogo (p. 302). 
O rei, ansioso por uma solução para a questão, regido pela celeridade, sente que se aproxima o momento de definição a respeito de quem será o futuro soberano. Contudo, o desenvolvimento do menino ainda não pôde torná-lo apto a encarnar essa função. A espera pelo despertar das capacidades do filho incomoda Maghan e a "dormência" das pernas dele passam a impressão de serem eternas para o pai, pressionado pelo curto tempo que the resta de vida para definir seu sucessor. Para que essas duas velocidades distintas venham a ser sincronizadas (fenômeno que ocorre adiante na narrativa), terão que passar por um ajuste (Zilberberg, 2011, pp. 104-105).

Há, nesse momento da história, a configuração de um segredo (ser e não-parecer), pois o indivíduo que é marcado pela nobreza ainda não aparenta sê-lo. Diante desse impasse, sua realeza (figura que investe a conjunção com a categoria do ser narrativo) não será identificada de imediato por Narê Maghan. Nesse momento da narrativa, chega a notícia de que o soberano teria outro descendente, do ventre de Sogolon, que voltara a engravidar. Isso traz uma suspensão momentânea no estado de incerteza do rei, que crê que o novo filho poderia sucedêlo. Porém, ao constatar que se tratava de uma filha (Kulukan), a sua esperança diminui ainda mais, até praticamente se extinguir.

Tendo sido quase extenuada a confiança de Maghan em Sundjata, cria-se a necessidade de busca por novos laços, para que a esperança de sucessão não esmoreça. Regido pela incerteza, o rei procura, em variadas ações, criar oportunidades para a geração de filhos. Isso se vê representado pelo fato de que Maghan interdita o acesso de Sogolon a sua residência e casase com a filha de um aliado, tendo outro filho com ela, Bukari. Contudo, na consulta que faz aos adivinhos a respeito do novo rebento, ele tampouco recebe a previsão de destino que o pai esperava; não seria ele o prosseguidor da sua governança.

A esperança pela geração de um futuro rei, ameaçada pelo risco de descontinuação da linhagem, praticamente se extingue em detrimento dos dois intentos frustrados de concepção de um prosseguidor (acima mencionados). Diante da nova disposição dos fatos, o rei manifesta novamente sua dúvida quanto à realeza inata de Sundjata: "Seria concebível que o filho inválido de Sogolon pudesse vir a ser aquele anunciado pelo caçador-adivinho?" (Niane, 1982, p. 34). Com esse questionamento, vem à tona, no nível narrativo, a modalidade da probabilidade, 0 não-crer-não-ser (Greimas e Courtés, 2012, p. 172). Apoiado pela fala de Nhankuman (que repete o dito do caçador: "A grande árvore nasce de um grão minúsculo", 1982, p. $34^{14}$ ) e por Nun Fairi, o ferreiro-adivinho de Niani, que, metaforicamente, confirma as palavras do caçador, o rei restabelece a sua confiança. Segundo a fala de Nun Fairi, "Quando a semente germina, o

\footnotetext{
${ }^{14}$ No original, "Le fromager sort d'un grain minuscule" (1960, p. 38).
} 
crescimento nem sempre é fácil; as árvores frondosas crescem lentamente, mas em compensação penetram suas raízes profundamente no solo" (1982, p. 34).

\subsubsection{Valores tensivos do desenvolvimento de Sundjata}

A fala do ferreiro é emblemática porque explica, com objetividade e precisão, os valores tensivos atribuídos ao desenvolvimento de Mari Djata (Sundjata). A lentidão é uma consequência do estabelecimento mais "enraizado" do personagem. Ao explicar metaforicamente esse fenômeno ao soberano, o ator "Nun Fairi" também atua na realização do que se denomina manipulação narrativa (fazer-fazer), transferindo um saber e fomentando a modalidade epistêmica do destinatário. A confiança do destinador "rei" no destinatário "Sundjata" se restabelece pela transferência dos valores modais crer e saber. No nível discursivo, esses são investidos pelo reconhecimento de que havia uma movimentação interna de crescimento, oculta dos olhares externos, que viria a tornar o filho inválido um grande governante.

O movimento lento e constante parece ser o princípio regente da emancipação do herói e uma máxima que se repete ao longo de toda a épica. Outro elemento, desta vez do nível narrativo, que está igualmente presente em boa parcela de sua extensão é a combinação do ser e do não parecer. Assim, na infância do protagonista, alguns traços que se verificam com frequência são aqueles da ordem da lentidão, do fechamento e do segredo. Trata-se de um ator que possui um desenvolvimento desacelerado, sua vida ainda gira em torno da casa da mãe e sua real potência permanece encoberta. O que acontece no decurso da narrativa, com a maturidade do personagem, é que essas características predominantes invertem-se. Há um crescimento vertiginoso quanto à velocidade, figurativizado na rápida campanha militar que promove e, igualmente, na vasta expansão territorial do império que realiza. Além disso, há também, a partir desse movimento, a ampliação de sua visibilidade e de seu reconhecimento, que ganham repercussão em nível mundial (Mari Djata se tornará um temido imperador). Vale lembrar que Sundjata, também conhecido como o leão do Mali, é um personagem lendário e histórico, conhecido tanto na literatura quanto nos estudos historiográficos.

O primeiro conjunto de traços mencionado acima (lentidão, continuidade e segredo) não está associado, na épica, somente ao ator Sundjata. Ao reconhecer que o desenvolvimento de uma árvore frondosa como a paineira ${ }^{15}$ vem de uma pequena semente, a fala do caçador-

\footnotetext{
${ }^{15}$ Niane, na versão em francês (1960, p. 38), chama a árvore de fromager. O tradutor opta pela tradução paineira.
} 
adivinho faz uso de um recurso conotativo, referindo-se ao desenvolvimento lento, mas vigoroso, do menino-leão. Há uma transferência de valores do universo da natureza para o campo da cultura nesse tipo de pensamento concessivo. O pequeno se tornará grande e o lento virará veloz, em um movimento oculto e contínuo.

A partir dos critérios propostos pela semiótica tensiva, pode-se afirmar que há, nesse momento, no eixo da intensidade, um andamento lento combinado com uma tonicidade crescente. Essa máxima também nos ajuda a compreender a "poética" concessiva do texto: a grandeza vem de um elemento marcado pela pequenez. A velocidade desacelerada é euforizada por ser nela justamente que se encontram as melhores condições para que ocorra a formação de um sujeito veloz. A partir do aprendizado em meio a esse ambiente, o personagem Sundjata torna-se apto a movimentar-se e a agir com uma rapidez surpreendente, quase sobre-humana, ao terminar o período de sua formação.

\subsubsection{Confiança}

Uma vez restabelecida a crença de Maghan na capacidade de Mari Djata, ele decide transmitir-lhe a função de governar o reino e oferece como griô o filho de Dua, Balla Fassekê, em uma cena significativa, na qual os quatro personagens estão numa mesma sala e parecem todos comungar de um profundo sentimento de confiança. Mesmo Sundjata, com sete anos então, já demonstrava compreensão e segurança ao receber o presente vindo do pai: "O menino, como se tivesse compreendido todo o sentido das palavras do rei, fez sinal a Balla Fassekê para aproximar-se. Cedeu-Ihe lugar sobre a pele em que estava sentado e disse-Ihe: Balla, serás meu griot." (1982, p. 35, grifo nosso). O reconhecimento da oferta do pai ocorre pelo que se pode denominar uma gestualidade mítica ${ }^{16}$. São os atos e a fala do menino Sundjata que confirmam a Narê Maghan (destinador-julgador), que o presente havia sido aceito.

Há, nesse instante, no nível narrativo, uma espécie de "comunhão fiduciária", na qual todos os actantes se veem confiantes nos laços contraídos. Para a descrição desse fenômeno, o conceito de contágio, formulado por Eric Landowski (2005), parece ter utilidade analítica, uma vez que prevê elementos "copresentes no espaço" que dão "um 'sentido sentido"' a partir do que chama uma "copresença actancial" (p. 104). O movimento retributivo do destinatário ("filho"), no que diz respeito à confiança do destinador ("pai"), relembra que o contrato

16 Greimas (1975, pp. 64-65), durante a análise do sentido da gestualidade, assinala duas de suas qualidades, o gesto prático e o gesto mítico, de difícil conceptualização, como reconhece. Por um momento, o autor baseia-se na dicotomia do fazer e do desejar para a diferenciação delas. 
fiduciário é um relacionamento "de mão dupla", no qual os dois actantes da manipulação atribuem e recebem confiança, um do outro.

Indo além da problemática acima, sobre os modos de interação entre a espacialidade, a actorialidade e os traços semânticos, vale mencionar um questionamento de Fontanille e Zilberberg (2001), que perguntam se “(...) Seria essa relação intersubjetiva [a fidúcia], por sua vez, dependente de uma relação reflexiva, isto é, da confiança em si?” (p. 263). Nesse sentido, é importante ressaltar que a chegada da "hora certa de agir", para a nomeação do filho como sucessor, não foi somente uma consequência da confiança que o rei adquiriu nele, pois houve também um movimento de obtenção de autoconfiança. Em termos do nível narrativo, apenas reconhecendo-se como competente e apto para realizar a sanção é que o destinador ("Maghan") pôde abordar o destinatário ("o futuro herdeiro") com confiança. Além disso, até que ponto ele teria sido apenas capaz de fortalecer o crer no destinatário a partir do momento em que este último também se tornou receptivo, e passou também a confiar mais em si mesmo? Como se vê, o estabelecimento do contrato entre destinador e destinatário é um fenômeno complexo, que depende de muitas variáveis, tal como o grau da modalidade potencial presente em cada um dos polos da manipulação narrativa, seja aquele que "faz fazer", ou o outro, que é incitado a agir.

O derradeiro apontamento à análise da confiança entre Narê Maghan e Sundjata está ligado à figura da continuidade da linhagem. Ao designar o filho de Dua como griô de seu rebento, o ator "rei" investe dois papéis actanciais (destinador e sujeito realizado) encontrandose, por fim, com a continuidade almejada. Se, por um lado, há aí um ator ocupando dois papéis actanciais, também se encontra, nessa passagem, um destinador investido por dois atores ("Maghan" e "Dua"). Como se trata de um prosseguimento de um vínculo familiar de três gerações, entre governantes e servos (o narrador explica que o pai de Narê Maghan também havia tido como griô o pai de Dua), há uma relação de confiança ainda mais fundada. Nos termos do nível narrativo, o investimento actorial do destinador (com o peso e reconhecimento de cada um dos atores estabelecidos) assevera as etapas de virtualização e competencialização do sujeito, dando um maior grau de certeza à efetivação dos programas narrativos pouco prováveis, que ele realizará mais adiante no desenrolar da história. 


\subsection{Sogolon Kedju}

Tendo sido investigado, com certa profundidade, o modo pelo qual a confiança do ator masculino que investe o destinador ("Narê Maghan") influencia os valores modais do destinatário ("o menino Sundjata"), chega o momento de analisar os processos semióticos pelos quais se estabelece o contrato fiduciário deste último com outro ator-chave da narrativa, que desempenha o papel de destinador, "Sogolon Kedju".

Embora possua uma similaridade com o rei, pois também se preocupa com a lentidão no desenvolvimento de Sundjata, a mãe do protagonista movimenta-se para transmitir valores a seu filho de uma maneira distinta daquela de Narê Maghan. Isso se dá porque, entre outras coisas, em diversos momentos da narrativa, padece com as humilhações infligidas por Sassuma Beretê. Eis um exemplo das provocações feitas pela última: “- Vem, meu filho, caminha, pula, salta. Os gênios nada te prometeram de extraordinário, mas eu prefiro muito mais um filho que anda sobre suas duas pernas a um leão que se arrasta pelo chão" (1982, p. 33).

A atuação do ator "Sogolon" é marcada pelo gesto de cuidado. Logo na primeira infância de Mari Djata, demonstrava preocupação quanto à "enfermidade" do pequeno e, em tentativas de remediar a sua falta de mobilidade, trazia outras crianças que já andavam para tentar fazer com que o filho se estimulasse a caminhar também (p. 33). Consternada com a situação de Sundjata, já via nele o surgimento de algumas habilidades precoces, que não se verificavam em outros meninos. Isso é verificável no seguinte trecho: "Dir-se-ia que ele já pensava; o que divertia os meninos de sua idade o aborrecia" (p. 33).

Assim, dentro da esfera do segredo, o menino-leão, ainda que não parecesse estar executando as etapas de seu desenvolvimento infantil, estaria de fato "fincando as suas raízes no solo", e, com elas, gestava, de modo oculto, o despertar tônico de sua juventude, cuja força vigorosa viria a superar as potencialidades das crianças "comuns" e desafiar as estruturas mais altas da sociedade na qual vivia. Fiorin (2012, p. 115), em uma breve análise das combinações entre modalidade narrativas, descreve os sujeitos que afrontam o sistema como heróis que agem por si mesmos, virtualizados no querer, mas não no dever. Sundjata, quando adulto, enquadra-se perfeitamente dentro dessa disposição modal, haja vista seu vigor expansivo, a despeito da resistência que existia por parte dos outros governantes de sua região.

Apesar de haver confiança no desenvolvimento do filho, verifica-se um grau de preocupação na mãe. Essa consternação torna-se cada vez mais acentuada, conforme se atrasa no menino a aprendizagem de uma das habilidades mais primárias da emancipação - a aptidão de se suspender em dois pés e caminhar. Mais uma vez, há um caso de assincronia de andamentos intersubjetivos, celeridade na mãe e lentidão no filho. Essa diferença de 
velocidades dificulta o estabelecimento do contrato fiduciário entre destinador e destinatário, pois gera um decréscimo de confiança. Ainda assim, o ator "Sogolon" não esmorece, mantendo firmes os cuidados com o menino.

Em dado momento da narrativa, após a morte de Narê Maghan, quando Dankaran Tuman assumiu o poder, Kedju e seu filho foram exilados a um canto modesto e afastado no palácio real. Antes dispondo de livre acesso aos cômodos, a mulher-corcunda viu-se obrigada a reduzir seu espaço de habitação e circulação e passou a viver de maneira mais restrita do ponto de vista material. Somado a esse contexto de fechamento, descontinuidade e privação, o conflito chega a seu ápice quando Sassuma realiza uma provocação (projeção de imagem desfavorável do destinatário, segundo Barros, 2002, p. 38) com o objetivo de desmoralizar a mãe de Sundjata. Isso ocorreu quando Sogolon estava sem condimentos para cozinhar e mandou pedir à rainha-mãe um punhado deles para o uso. Recebeu como resposta a seguinte fala: "Meu filho, com sete anos já andava e era ele quem ia colher para mim as folhas de baobá. Podes levar, pobre mãe, já que teu filho não vale tanto quanto o meu" (1982, p. 37). Depois dessa afronta, a tonicidade da humilhação recrudesce, somando-se ao sentimento de falta de confiança, que já se encontrava estabelecido.

O que segue na narrativa é a saturação do sofrimento de Sogolon Kedju, que explode em choro e, com um pedaço de pau, bate em seu filho. Sundjata, compassivo à dor da mãe e sentindo a da pancada, contudo, não se exalta. Ciente da necessidade de se levantar, o rapaz, como que plenamente seguro da sua capacidade de realizar uma transformação, pede a seu griô que lhe busque uma vara de ferro nas forjas reais, não sem antes terminar de comer sua cabaça de arroz calmamente.

A ausência de uma reação apaixonada do menino ao processo catártico da mãe surpreende por não trazer a tonicidade esperada em um momento como esse. Por outro lado, novamente atuando na esfera do segredo (não parecer e ser), essa aparente tranquilidade estaria apenas ocultando a determinação de agir. Sundjata pretendia fazer frente aos insultos desferidos contra a sua pessoa e sua família. A ocasião aparece no tempo esperado pelo herói, pois chega a barra de ferro que se encontrava misteriosamente armazenada há tempos nas oficinas de Farakuru. O menino-leão ergue-se, curvando o ferro da vara ao mesmo tempo em que endireita suas pernas.

Um processo de transferência de valores semânticos ocorre nesse ponto. Trata-se de uma comunicação dupla. Por um lado, o traço /curvo/ das pernas é passado à vara; por outro, o /reto/ do ferro é transferido aos membros. É justamente essa a passagem do livro que marca a emancipação do personagem de maneira mais enfática. Sundjata sai em busca do baobá, o encontra e traz a árvore inteira em suas costas até a entrada casa da mãe, "lavando" as afrontas 
sofridas e convertendo o estado de penúria em que sua família vivia em algo próximo à fartura. De maneira paralela, o bem-estar de que a família de Sassuma Beretê gozava antes da passagem narrativa acima se altera, pois se vê ameaçado pelo temor da perda de privilégios. O medo encontra-se figurativizado na narrativa, entre outros elementos, pelo tremor de corpo da rainha-mãe, o que não deixa de ser uma ruptura na retilinidade de suas estruturas corporais (1982, p. 40).

Pode-se traçar uma regularidade com respeito à foria de alguns semas presentes no recorte estudado da epopeia de Sundjata. A isotopia da /verticalidade/ está geralmente vinculada à euforia. Ela é figurativizada pela capacidade de ficar de pé do protagonista, em uma celebração do êxito do programa narrativo diante do antiprograma. O crescimento do baobá também possui esse traço semântico. A lentidão e o vigor no período da formação são algumas características comuns entre o herói e o tipo de árvore. Por sua vez, a isotopia da /horizontalidade/ encontra-se associada a temas disfóricos, tais como a imaturidade, ou algumas figuras que "se estendem" lateralmente, como a propagação das calúnias pelos habitantes do Niani, feitas por Sassuma Beretê.

Conforme mencionado acima, durante grande parte da narrativa, a tardança do surgimento da competência do filho de andar, saltar ou correr não imobiliza Sogolon. Mais do que se demorar em grandes padecimentos com as provocações vindas da primeira mulher de Narê Maghan, ela mantém-se ativa, procurando valer-se de todos os meios disponíveis para fazer o menino erguer-se: "ela já se havia valido de todo o seu talento de conhecedora das magias, na tentativa de dar força às pernas de seu filho; não obstante, as ervas mais raras se tinham mostrado ineficazes" (p. 33). A ação do ator, instiga, como destinador, a continuidade do fluxo narrativo e não faz grande caso às suspeitas vindas das fontes de incerteza (não-crerser) presentes na narrativa. Nesse momento, faz-se oportuno evocar a seguinte reflexão, proposta por Tatit (2010), a partir da análise de um conto de Guimarães Rosa:

O que importa ao destinador transcendente é levar o destinatário-sujeito a fazer, antes mesmo que se configurem os valores descritivos ou modais. Em outras palavras, enquanto esses valores não se manifestam, não custa nada, de acordo com o viés do destinador, já manter o percurso em andamento (...) "fazer de conta" é buscar o valor de sua configuração temática e figurativa. (Tatit, 2010, p. 30, grifo do autor).

O Tio Man'Antonio, personagem de "Nada e a nossa condição", age de modo a desencadear "o dispositivo sintáxico que faz a vida prosseguir" (p. 30). Reconhecendo que a vida 
inevitavelmente possui momentos conjuntivos e disjuntivos, o destinador do conto vê no fazer uma maneira de estar a caminho de melhorar, mesmo durante as etapas difíceis, e dá conta das descontinuidades da vida por meio da ação. A personagem Sogolon Kedju é regida por esse princípio narrativo. Seus esforços constantes pela melhora das condições do filho, obstinados apesar de não receberem nenhuma garantia de que estariam sendo aproveitados, não se deixam importar pelas incertezas advindas da lentidão do desenvolvimento de Sundjata. Tampouco se deixa abater por "indagações existenciais da humanidade que têm na morte inexorável o seu principal mistério" (2010, p. 32). Como o personagem de Guimarães Rosa, a mulher-corcunda, ao desempenhar o papel de destinador, "faz de conta" que seus intentos estão sendo efetivos e mantém o fluxo da narrativa. $O$ esforço é mencionado pelo narrador de L'Épopée Mandingue como uma das principais virtudes da figura materna. Segundo ele, as qualidades dos pais refletem diretamente nas dos filhos, “(...) - como se dizia - quanto mais uma mulher ama seu marido, quanto mais ela o respeita, quanto mais ela sofre por seu filho, tanto mais este último será um dia valoroso" (1982, p. 41).

Sogolon é a principal personificação dessa característica no texto, não somente pela capacidade de aturar e resistir, mas também por sua força. Antes de ser apresentada a Maghan, logo após ter sido trazida de seu país de origem, a descrição que o narrador faz dela remete a uma mulher forte, que possuía "braços musculosos", uma "corcova que deformava suas espáduas" e "seios fartos" que pressionavam firmemente o algodão que se enrolava sobre o tórax (p. 20). As figuras mencionadas parecem, todas, remeter a um traço de excesso, seja ele associado à força física, à rigidez das costas ou até a uma corporalidade "abundante".

Outro momento da narrativa no qual essa característica de Kedju se manifesta é quando oferece resistência ao momento da cópula, que supostamente ocorreria na noite após o casamento. A relação amorosa é impedida de acontecer pela mulher, que parece estar, nesse instante, possuída por uma força sobrenatural. Narê Maghan, expressando seu temor de não poder cumprir com os deveres conjugais, chega a dizer a seu griô: "essa moça me atemoriza. Chego mesmo a duvidar que ela seja um ser humano; quando eu me aproximava dela, durante a noite, seu corpo se eriçava de longos pelos, o que me provocava medo" (p. 27). Apenas com um truque de astúcia, enganando-a com a mentira de que teria que sacrificá-la, o rei pôde possuí-la, desacordada pelo choque que teve ao ouvir que seria morta.

Há um interessante vínculo entre as características dos seres humanos e dos animais na épica de Sundjata. Os traços animalescos parecem ser transmitidos aos homens por meio de associações mágicas. No trecho analisado da épica, primeiramente, há o caso da velha que é, simultaneamente, o temido búfalo de Do (aquela que matou cento e sete caçadores e feriu setenta e sete), e a irmã do rei do mesmo país. Ela desejava punir o soberano porque este não 
Ihe havia dado sua parte da herança. A mãe do protagonista termina, de certo modo, por ser sua "prosseguidora". A senhora indica aos caçadores que escolham a mulher-corcunda (Sogolon) como recompensa pela derrota do búfalo, embora ela fosse muito mais feia do que as moças do lugar, as quais poderiam ser escolhidas livremente pelos vencedores. Os temas da força e da resistência, associados à figura do animal, permanecem vivos nas características dos personagens. "Sobreviventes" das transformações narrativas que acontecem na história, eles transitam de ator em ator, sob a forma de algo que poderia ser descrito como um "espírito", que carrega em si os valores mencionados. Aparentemente, esse mesmo "poder" é transmitido ao menino Sundjata, chamado por muitos de Sogolon Djata durante a sua infância (sinal de seu vínculo com a característica materna). Desde cedo, ele demonstrava ter grande força, como na cena em que surrava os meninos que tentavam aproximar-se dele (p. 32).

Nem só de seus esforços vale-se Kedju para sustentar sua força. Kulukan, sua primeira filha, também precisa ser mencionada como peça-chave na disposição de força e confiança de "A Epopeia mandinga". Antípoda de seu irmão, ela teve um rápido desenvolvimento. Aos quatro anos, já auxiliava a mãe nos afazeres domésticos, o que era uma consolação para a esmerada personagem. As mulheres da narrativa de "Sundjata" possuem a característica de serem mais resistentes às adversidades do que os homens. No momento em que o rei perde a confiança no filho, Sogolon é quem permanece ao lado do rapaz (p. 33). Após a morte do soberano, novamente, são as personagens femininas que acompanham-no em sua jornada no exílio, rumo ao que se pode depreender (no nível narrativo) como o percurso de aquisição das modalidades de poder do sujeito, necessárias, no caso, ao estabelecimento do protagonista na função de governante do reino (p. 35).

Em oposição ao ideal do cuidado, amor e resistência nesses atos - euforizados no texto - há, como correspondentes contrários, a indiferença diante dos outros e da própria família. Sassuma é a personagem que encarna esses valores, descrita como uma mãe que não honrava marido ou filho. O narrador, em dado momento da história, afirma que "Não era de se espantar, portanto, que o rei Dankaran Tuman fosse tão medíocre; sua mãe jamais manifestara o menor respeito ao marido" (p. 41). 


\subsection{Manipulação do protagonista}

Para concluir as observações deste capítulo, é preciso reconhecer que o desenvolvimento do personagem Sundjata não decorre somente de sua natureza privilegiada, nem apenas de seu mérito próprio. Somado ao espírito deveras impetuoso do menino, há a presença do que se denomina, no nível narrativo, um destinador transitivo e transcendente. De um lado, este se encontra actorializado pela mãe Sogolon Kedju, e do outro, pelo pai Narê Maghan. Da primeira, o destinatário recebe valores figurativizados pelo amor, graças a um vínculo vigoroso e contínuo. Do segundo, recebe, sobretudo, os valores do saber e poder-fazer, além dos reforços tímicos vindos da confiança (crer). No plano discursivo, esses valores representam o aval necessário à continuidade da linhagem real e ao estabelecimento de Sundjata como ator emancipado.

Por outro lado, como se vê, o estabelecimento do herói não se dá apenas pela atuação dos atores "mãe" e "pai", mas também pelas relações de crença e doações de competências "menores", vindas de outros personagens da narrativa (os griôs Nhankuman Dua e Balla Fassekê, os caçadores, o caçador-adivinho de Sangaran, o ferreiro Nun Fairi, a irmã Kulukan, entre outros). Além deles, é necessário que se mencionem os laços ancestrais e mágicos que deram força a seu advento (a força do búfalo, do baobá e o laço intergeracional entre pais e griôs, por exemplo). O período de formação de Sundjata no Niani representa, sobretudo, a etapa narrativa da potencialização, na qual o sujeito estabelece o crer primordial em seus destinadores. A aquisição das modalidades do querer e do dever-fazer (virtualização), em sua longa jornada como descendente real, também é um fenômeno narrativo que se encontra presente nessa passagem do texto. Depois disso, ainda precisará passar pelas outras transições que também são necessárias para a efetivação do programa narrativo de base da épica, que é o estabelecimento do império Mandinga.

Durante a análise da construção de fidúcia, viu-se que o texto privilegia a manipulação transitiva, realizada pelos dois personagens que investem o papel de destinador, Narê Maghan e Sogolon Kedju. Nesse sentido, o foco narrativo diz pouco sobre o "mundo interno" do protagonista, respeitando, pelas escolhas implícitas do narrador, o ocultamento e o mistério que existem por trás da constituição da personalidade de Sundjata. Essa parece ser uma das principais diferenças que esse texto guarda em relação ao restante do corpus deste trabalho, que são as entrevistas coletadas com jovens (apresentadas nos próximos capítulos), pois essas fazem, como se verá, um maior aprofundamento no universo interno dos protagonistas. 
Assim, para dar prosseguimento ao estudo da presente dissertação, o olhar dirige-se, agora, aos depoimentos que foram coletados com a finalidade específica de trazer referências mais contemporâneas sobre os processos de aquisição de emancipação. 


\section{Discursividade da emancipação nas entrevistas}

O estudo das entrevistas requer uma atenção especial. Por isso, as ideias surgidas foram agrupadas por níveis de significação. A opção de classificar os fenômenos constatados em três capítulos ("2. Discursividade da emancipação nas entrevistas", "3. Narratividade da emancipação nas entrevistas" e "4. Comentários tensivos e extratextuais") permitiu uma disposição mais organizada das construções de sentido presentes em cada um deles. Essa escolha foi tomada em razão de, por um lado, privilegiar a análise dos universos discursivos referentes ao assunto, chamando a atenção para a sua contemporaneidade e, por outro, de investigar, de modo mais aprofundado, os recursos narrativos e as disposições modais que se encontram subjacentes à emancipação, fontes de reflexão interessantes no que diz respeito às estruturações do ato. Ainda, as constatações referentes à aspectualidade e ao nível tensivo auxiliam na depreensão das estruturas valenciais por detrás dos textos do corpus. Os traços aspectuais por vezes aproximam-se das manifestações tensivas, pois ambos tratam, de certo modo, das gradações e medidas dos valores linguísticos. As conversões entre níveis de significação são também exploradas em cada capítulo, antes de se passar às seções seguintes.

Este capítulo trata do nível da discursividade dos textos orais proferidos pelos jovens entrevistados. Antes das considerações textuais propriamente ditas, os temas e as figuras são sintetizados, com vistas à obtenção de um panorama semântico do que foi atribuído pelos informantes a suas buscas de emancipação. Em seguida, adentrando no trabalho com o texto, a análise dirige-se às figuras discursivas que se destacam por suas particularidades. No penúltimo item desta etapa de análise, observam-se os procedimentos de actorialização, espacialização e temporalização presentes em alguns trechos de entrevista. Por fim, comentários de cunho interdisciplinar são realizados, com vistas ao estabelecimento de diálogo com alguns estudos feitos sobre o mesmo tema, em outros campos da ciência.

\subsection{Panoramas temático e figurativo articulados em forias}

Além da identificação dos elementos discursivos presentes no corpus, discrimina-se aqui a sua classificação nas categorias fóricas. Essa escolha justifica-se por conta dos seus ganhos analíticos, pois oferece ao pesquisador, de modo esquemático, um vislumbre do que é dito nos textos, e do valor que isso possui, do ponto de vista da foria, para o sujeito. Outra razão que determina esse procedimento é a confrontação que assim pôde ser estabelecida com os resultados encontrados nos estudos de Harkot-de-La-Taille (2011) e Harkot-de-La-Taille e 
Françoise Bariaud (2013). Esses dois artigos são dedicados à compreensão do discurso de jovens brasileiras e francesas e procuram investigar a construção do conceito de adultez por meio da análise de material coletado. Em uma das suas seções, as autoras utilizam como base a metodologia de discriminação de temas e forias, que inspirou o procedimento adotado abaixo.

A classificação dos temas presentes nos textos do corpus em exame dividiu-os como eufóricos, disfóricos ou mistos. Quando se fala nesta última possibilidade, isso significa que os temas são tratados ora como eufóricos, ora como disfóricos nos textos.

\begin{tabular}{|l|l|l|}
\hline \multicolumn{2}{|l|}{ Tabela 1 - temas presentes nos discursos dos jovens entrevistados } \\
\hline Apenas eufóricos & Ambos & Apenas disfóricos \\
\hline Independência* & Mudança & Estaticidade / estagnação \\
Liberdade* & Assentamento & Rejeição \\
Transformação social & Formação & Medo \\
Cultura & Trabalho & Perda \\
Diversidade & Família & Ensimesmamento \\
Beleza & Responsabilidade & Solidão \\
Relacionamentos & Recursos & Cansaço \\
Moradia & Dependência & Tristeza \\
Conquistas & & Dúvida \\
Respeito às diferenças & & Pressão social \\
Convívio & & Abandono \\
Desejo de criar algo & Segregação \\
Colaboração & Peso \\
Conhecimento & Contenção \\
Viagem & & Violência \\
Cuidado com os outros & & \\
\hline * Os termos autonomia & & \\
\hline
\end{tabular}

* Os termos autonomia e emancipação foram omitidos por serem entendidos como pertencentes ao mesmo campo temático de independência e liberdade.

Harkot-de-La-Taille e Bariaud realizaram uma análise semiótica sobre discursos coletados em cinquenta entrevistas compreensivas (com duração entre oito e 45 minutos), realizadas com jovens francesas (14 informantes da cidade de Rennes, feitas em 2007) e brasileiras (36 informantes da cidade de São Paulo, em 2010). A idade das entrevistadas variava entre 15 e 25 anos de idade. Nesse artigo, intitulado "'Ser adulto', por jovens francesas e brasileiras em 2007 - 2010", as autoras analisam os resultados ora de maneira integrada entre as informantes de cada um dos países, ora vislumbrando as diferenças que cada nacionalidade trazia aos discursos. 
Ao se realizar uma comparação entre os resultados das pesquisadoras e os do presente estudo, a variante gênero não pode ser levada em conta. Isso ocorre porque o corpus dos artigos acima mencionados compõe-se apenas de informantes do gênero feminino e as entrevistas deste trabalho contam com 50\% de homens e 50\% de mulheres (dois informantes de cada sexo). Apesar dessa diferença, as relações aqui identificadas permitem ressaltar os temas que estiveram presentes no discurso dos jovens, independente dos gêneros. Assim, podem ser feitas asserções relativamente gerais quanto ao grupo dos jovens de São Paulo. A importância das relações de gênero para a compreensão dos fenômenos analisados no segmento dos jovens é, contudo, indiscutível, entre outras razões, pela necessidade de implementação de políticas públicas que visam à obtenção de mais igualdade de oportunidades para a população ${ }^{17}$.

A amostragem que esta pesquisa traz é significativamente menor que a de Harkot-deLa-Taille e Bariaud (quatro versus 50 entrevistados) e não poderia aspirar à mesma abrangência que a investigação das autoras. Além disso, há que se levar em conta o fato de que cada estudo partiu de roteiros de entrevista diferentes, embora relacionados, e que os perfis sociais dos jovens são, também, divergentes. No artigo das autoras, as entrevistadas foram divididas em três segmentos etários: 15 a 17, 18 a 22 e 23 a 25 anos (2013, p. 414). O cruzamento de informações realizado aqui precisou desconsiderar essa partição, pois os informantes do presente trabalho tinham entre 20 e 28 anos na data das entrevistas e a sistematização de temas e figuras foi feita sem a diferenciação por idade.

O corpus desta dissertação deu prioridade a informantes negros que tivessem projetos pessoais ou profissionais propositivos no sentido de empreendimentos ou transformações sociais e culturais dentro da sociedade. Os temas juventude, emancipação e visão de adultez fizeram-se presentes nos textos de ambos os trabalhos (neste e nos artigos mencionados). Não deixa de ser intrigante, contudo, o fato de que essas duas investigações, realizadas com jovens de perfis sociais bastante variados, respondendo a perguntas diferentes e em contextos distintos, tenham resultado em configurações bastante semelhantes, no que se refere ao panorama de temas discursivos encontrados.

À primeira vista, a coincidência de alguns temas e de suas forias, encontrada pela comparação dos resultados obtidos pelas autoras e pelo presente estudo, respalda a hipótese de considerar como próprias dos jovens de São Paulo tais associações discursivas. A juventude francesa, representada pelas 36 informantes entrevistadas, vista em comparação com a do país

\footnotetext{
${ }^{17}$ Alves e Cavenaghi (2013) expõem essa importância em seu artigo "Indicadores de desigualdade de gênero no Brasil”.
} 
latino-americano, também parece gozar de muitas semelhanças quanto a essas particularidades.

Quando analisam o discurso das jovens brasileiras e francesas, Harkot-de-La-Taille e Bariaud identificam como eufóricos os temas relações amorosas, plenitude (ter), sabedoria, desejo de criar algo, conquistas, desenvolvimento moral, desejo de criar família e desenvolvimento afetivo. Foram identificados como co-ocorrentes nesta dissertação os temas relacionamentos ${ }^{18}$, sabedoria (conhecimento, no presente trabalho), desejo de criar algo e conquistas. As entrevistas colhidas para este estudo, por outro lado, excedem essas tematizações, trazendo independência, autonomia, transformação social, cultura, diversidade, beleza, moradia, respeito às diferenças, convívio, colaboração e viagem como temas somente eufóricos.

A coincidência temática nas categorias mistas de euforia e disforia deu-se nos temas mudança, família e assentamento. No que toca aos temas apenas disfóricos, são pontos de convergência entre os resultados deste trabalho e os do artigo os temas pressão social, estresse, rotina (aproximado do que aqui foi nomeado como estagnação / estaticidade) e perda (2013, p. 414).

Apesar de trazer aspectos oportunos para a reflexão, a listagem temática obedece a critérios de classificação que possuem possibilidades descritivas relativamente abertas, o que dificulta um pouco o trabalho de comparação. Outro ponto digno de nota é a problemática da delimitação entre os elementos temáticos e figurativos. Esses conceitos são, até certo ponto, permeáveis, do ponto de vista teórico. Ainda assim, os resultados encontrados são úteis porque trazem uma compreensão panorâmica do campo discursivo tratado pelas entrevistas. Isso facilita a compreensão do objeto de estudo (a emancipação dos jovens) e seus contrastes em relação aos resultados de Harkot-de-La-Taille e Bariaud.

No momento no qual se focalizam as figuras discursivas dos textos coletados, pode-se trabalhar com uma metodologia semelhante à realizada acima, os termos são divididos por suas disposições fóricas. O número de ocorrências encontradas é maior do que o de temas, como era de se esperar, por tratar-se de um nível mais superficial do ponto de vista do percurso da significação.

18 Próximo da categoria relações amorosas, encontrada pelas autoras. 


\begin{tabular}{|c|c|c|}
\hline Apenas eufóricas & Ambas & Apenas disfóricas \\
\hline Trabalhar no terceiro setor & Redes sociais & Rotina \\
\hline Enxergar a própria beleza & Morar na casa dos pais & Falta de estudo na família \\
\hline Banda de música & Universidade & Zona de conforto \\
\hline Maternidade & Arrumar emprego & Vergonha do próprio corpo \\
\hline Namorar & Sair de casa & Rejeição por parte de colegas \\
\hline Viajar para outros países, estados, & Dependência & Escola \\
\hline cidades & Vestibular & Bagunça \\
\hline Querer estar entre amigos & Escola & Preconceito e discriminação racial \\
\hline Atuar pela transformação do país, da & Trabalhar em ONGs & Morar em local insalubre / de risco \\
\hline sociedade e da cidade & & Morte de irmão \\
\hline Transitar pelo centro da cidade & & Faltar comida / passar fome \\
\hline Passear no bairro onde se mora & & Ônibus lotado \\
\hline Passar conhecimentos a outros jovens & & Muitos anos trabalhando na mesma \\
\hline Cultura (capoeira, música, dança, & & empresa \\
\hline $\begin{array}{l}\text { cinema, teatro, literatura, saraus e } \\
\text { debates) }\end{array}$ & & $\begin{array}{l}\text { Trabalhar em empresa de grande } \\
\text { porte }\end{array}$ \\
\hline Conviver com pessoas de outras & & Bolsa em escola particular \\
\hline idades & & Cobrança por mais presença na \\
\hline Encontrar / proporcionar alternativas & & família \\
\hline ao sistema & & Sistema CLT \\
\hline Viver em São Paulo / em uma cidade & & Viver em cidade pequena \\
\hline grande & & Violência policial \\
\hline Autoconhecimento & & Violência doméstica \\
\hline Identidade racial & & Violência racial \\
\hline Transitar por vários grupos / & & Racismo \\
\hline comunidades & & Abuso sexual \\
\hline Produzir cultura & & Distúrbios mentais \\
\hline Cabelos afro & & Assistencialismo \\
\hline
\end{tabular}

Como se vê, a variedade de figuras é relativamente grande e elas encontram-se distribuídas em um número equilibrado entre as articulações apenas da disforia e aquelas apenas da euforia, estando em menor quantidade as que são vistas ora como eufóricas, ora como disfóricas. Mais do que comparar as figuras por quantidade de ocorrências e variedade de campos semânticos, é interessante analisar algumas particularidades que são disparadoras de reflexões oportunas. Primeiramente, as diferentes articulações fóricas dadas aos temas da dependência e da independência são tomadas como foco, na compreensão dos processos de emancipação presentes no corpus. 


\subsection{Dependência e independência}

Como mencionado acima, a dependência e a independência são bons pontos de partida para a compreensão dos procedimentos que subjazem ao sentido de emancipação no plano discursivo. A independência, por vezes, é tomada como fenômeno pontual e, outras vezes, como durativo contínuo (Barros, 2002, p. 91). A temporalização com a qual é localizada discursivamente (concomitante, anterior ou posterior à narração, ou aos tempos do narrado) também varia. Para a conceituação de tempo da narração e do narrado, foi utilizada a proposição de Mariana L. P. de Barros (2009).

$\mathrm{O}$ jovem AV24, nos primeiros momentos de sua entrevista, afirma não saber se é independente. Para ele, a resposta ao questionamento feito pelo entrevistador ("você se considera uma pessoa independente?") é uma incógnita. O entrevistado afirma o seguinte: “independente eu não sei assim porque::... a gente vem com a nossa caminhada com nosso percurso a gente:... acaba tendo:: a colaboração de tanta gente né? então você não sabe se você está ar/ se você está totalmente independente né?" (Anexo, p. 1, grifo nosso). A dúvida se dá, em primeiro lugar, porque a independência, para ele, corresponde a uma passagem importante e que dura no tempo. Nesse sentido, rege continuamente as ações das pessoas. Também se nota que a aquisição de independência é tida por ele como um processo "em curso".

Ao ressaltar a influência de elementos externos no caminho de se tornar independente, o entrevistado reconhece ter dependência em algumas áreas da vida, em especial naquelas relacionadas ao campo afetivo ("você precisa de amor... você precisa dar amor... você precisa... é::... comER... você faz a comida para o outro comer... ou alguém faz para você comer...", Anexo, AV24, p. 1, grifos nossos). Assim, não apenas pelo último trecho transcrito, mas também por outras passagens que se apresentam ao longo da entrevista, vê-se que a dependência é disposta, por esse entrevistado, como tema não disfórico.

CS20 por sua vez, responde à mesma questão de uma maneira distinta.

“E: (...) você se considera uma pessoa independente?

C: $\operatorname{sim}$

E: por que?

C: porque eu não... sei lá... não dependo de ninguém?... ah... sei lá... eu gosto de fazer as coisas tudo sozinha... é isso... deixa eu ver... que mais?... é isso... é isso" (Anexo, CS20, p. 5, grifos nossos) 
Com um estilo mais sucinto, a entrevistada afirma ser independente, e justifica essa constatação por meio da afirmação de que considera eufórico o ato de fazer as coisas só Vale pontuar que cada um desses dois entrevistados utiliza em seu discurso uma acepção própria para a independência. O primeiro deles confere valor não disfórico ao relacionamento com os outros, considerando necessário que o jovem se valha disso como uma forma de chegar a alcançar mais liberdade em sua vida. Refere-se à dependência como algo inerente ao jogo de relações humanas no mundo, que é concebido por ele como uma rede. Para AV24, independência não poderia existir sem o reconhecimento dessa premissa.

A segunda entrevistada valoriza, sobretudo, os valores e as ações vinculados à independência e ao fazer individualizado, sem fazer, nesse momento do discurso, menção às relações de dependência. CS20 trata independência de um modo pontual. A passagem na qual afirma isso, do ponto de vista da temporalização, refere-se a um ato feito em anterioridade quanto ao tempo da narração.

SM28 traz, ainda, uma terceira forma de tratar o tema.

"eu sempre / sempre gostei de / desse: / dessa pegada de estar mais: independente de fazer minhas COlsas... de escolher o que eu quero faZEr de escolher o que eu quero estudar eu acho que / que uma das coisas que / que fiCOU muito da / da minha formaÇÃo da / da educação que que recebi... dos meus pais e mais ainda da minha mãe é que:... é:... eu podia ser... várias coisas... que eu tinha oportunidade de / de:... de SER né?" (Anexo, SM28, p. 18, grifos nossos)

O narrador euforiza a independência e, mesmo não chegando a se posicionar diretamente quanto à dependência, nota-se que o primeiro termo é mais bem visto por ele do que o segundo. Menciona os pais como referências importantes em seu processo de aquisição de independência, concebido a partir do que se pode denominar uma aspectualidade durativa contínua (expressa pela palavra "sempre"). Nesse momento, do ponto de vista narrativo, o ator "pais" desempenha o papel de destinador transitivo, pois é o responsável pela comunicação dos valores necessários à vida independente do ator "SM28". No trecho transcrito anteriormente (de CS20), há sincretismo actancial, ou seja, um ator somente desempenhando os papéis de destinador, destinatário e sujeito. Eis uma das principais diferenças entre os dois últimos extratos de texto.

O outro entrevistado, JS23, por sua vez, trata o tema de um modo diferente. 
"acho que:... a independência não vem do momento que:... você sai da sua casa / eu acho que ela sai do momento em que você começa a libertar sua mente para as coisas novas... quando você deixa de... de sonhar o sonho de outras pessoas e querer sonhar o seu sonho e ir em busca dele... acho que é o que te torna independente... não o estar dentro da casa da mãe, ou o estar dentro da casa do pai ou do tio $\{\mathrm{E}$ : ahn $\{\mathrm{J}$ : se tornar independente é poder sonhar... tentar realizar seus sonhos... os SEUS sonhos não os sonhos que seus pais querem que você sonhe" (Anexo, JS23, p. 9, grifos nossos)

Quando se constata que, para essa passagem, a independência não está relacionada diretamente à condição de moradia dos jovens, pode-se afirmar que o foco de atenção foi desviado do ator "pai, tio ou outras pessoas". A presença ou a ausência deles não é considerada determinante na constituição dos indivíduos. Nesse sentido, pode-se afirmar, com base em critérios tensivos, que o texto confere baixa tonicidade à ação desse ator, preferindo, ao contrário, ressaltar o que realmente considera um diferencial para a problemática da aquisição de independência pelos jovens, a capacidade de sonhar os próprios sonhos. Essa ênfase pode ser verificada até no nível prosódico, quando se ressalta o pronome possessivo, em "OS SEUS sonhos". Nesse sentido, as estruturas encontradas no discurso desse entrevistado aproximamse do sincretismo actancial, também encontrado em CS20. Do ponto de vista da temporalização, nota-se que a concepção de independência presente em JS23 remete a um ato durativo. Além disso, o processo de emancipação relatado encontra-se em relação de concomitância com o tempo da narração.

\subsection{Actorialização e espacialização}

Outra reflexão digna de nota que se pode inferir a partir da discursivização das falas de AV24, CS20, JS23 e SM28 - tratando agora de pontos que dizem respeito aos elementos actoriais dos discursos - é a abordagem mais coletivizada que o discurso do primeiro traz com relação aos outros. AV24 associa os valores de independência a grupos de pessoas, trazendo maior abrangência actorial ao ato. Os demais entrevistados, por sua vez, transitam no sentido contrário, vendo independência como um ato mais individualizado.

Na entrevista de AV24, o tema colaboração é usado para designar a influência, bemvinda, do ator "outras pessoas" sobre aquele que busca se emancipar. As marcas enunciativas presentes na frase “você não sabe se você está (...) totalmente independente né?" (Anexo, AV24, p. 1, grifo nosso) revelam, nesse caso, o uso da segunda pessoa do singular (você), para significar a primeira pessoa do plural (nós). Nesse sentido, há um artifício linguístico para criar um efeito 
de proximidade enunciativa. Do ponto de vista formal, o enunciador aproxima o enunciatário ao qual se dirige, ao passo que, da perspectiva da significação, as palavras ganham uma generalidade, que fazem com que o "você" da enunciação sinta-se parte de um grupo de indivíduos cuja abrangência não é possível precisar ("os jovens", "os homens"), mas que se mostra unido quanto à vontade de adquirir independência.

Seguindo nesse trecho da entrevista, agora se referindo aos elementos espaciais, vê-se que eles são evocados metaforicamente pela figura da "caminhada". Na frase "a gente vem com a nossa caminhada com nosso percurso a gente:... acaba tendo:: a colaboração de tanta gente né?" (Anexo, AV24, p. 1, grifos nossos), associa-se a busca por independência a um deslocamento contínuo e de longa dimensão. A figura produz a impressão de espaço amplo. Isso se verifica também em outra passagem na resposta do entrevistado, "hoje eu consigo ter independência na mobilidade urbana... hoje eu consigo ir até o centro de São Paulo... hoje eu consigo ir para outros Estados... posso:... po/ quebrei as barreiras da minha::... da minha mente assim nessa questão da independência entendeu?..." (Anexo, AV24, p. 1, grifos nossos). Há, nesse momento, no plano espacial, uma sequência de figuras que crescem em extensão, por meio de uma ocupação cada vez mais ampla e distante do narrador (saída da comunidade periférica ao centro de SP e então a outros Estados do país).

De modo geral, há, no discurso de AV24, associação de independência a uma actorialização abrangente (coletivizada) e a uma espacialidade extensa (que recobre espaços "distantes" do seu bairro e outros Estados do país). Do ponto de vista da temporalização, vê-se que ela é durativa, evocada pelo sentido de processo. Além de associar o conceito de independência a estruturas discursivas mais ligadas à abertura e à amplitude, a fala do entrevistado também confere à obtenção de emancipação um caráter central dentro das práticas pessoais, mostrando-se fortemente dirigida a essa causa e esforçando-se por construir a autoimagem de indivíduo que se dedica a esse projeto.

Com CS20, como dito, o que acontece do ponto de vista actorial é diferente, pois a entrevistada não fala em nome de ninguém mais do que ela mesma, ou seja, a actorialização, em seu discurso, vale-se de uma estrutura individual. Diz que gosta de fazer "as coisas" sozinha, reforçando seu caráter autônomo (Anexo, CS20, p. 5). Sua fala é caracterizada pela euforização da não dependência.

Apesar de se referir a um relativo fechamento nos âmbitos actorial e aspectual, pelo uso de estruturas singularizadas e de formas terminadas e pontuais da temporalidade, as declarações de CS20 remetem, por outro lado, a uma espacialidade que se encaminha a uma leve abertura. Isso ocorre, por exemplo, quando declara que tem ido além dos lugares que normalmente visita, como o campeonato de música. Tal "expansão de territorialidade" 
expressa-se por figuras como sair de casa sozinha, a pé ou de ônibus, transitar pelo seu bairro e pela ida a eventos.

Essa entrevistada associa independência ao ato de ir além da circunscrição espacial dos pais. Por outro lado, revela que, embora tenha ido "sozinha" a um campeonato de música, os amigos e integrantes de sua banda encontravam-se presentes no local na ocasião, o que, do ponto de vista analítico, não permite configurar a ação como um ato inteiramente individual. Nesse mesmo espaço, ocorre a "encenação" de uma passagem que CS20 considera ilustrativa de seu processo de obtenção de independência.

“C: (...) ir para um campeonato... campeonato de música sozinha assim com o povo... sabe?... que eu me lembre... foi isso...

E: você::... era só/ era um Sólo? você cantava sozinha? ou tinha... outros músicos?...

C: não eu fui assim é... com todo mundo do meu grupo assim... sozinha assim sabe?... minha mãe não precisou ir... né?...

E: ah $\operatorname{sim} . .$.

C: tipo: eu fui in-de-pen-den-te... sozinha... eu e o povo

E: ah sim... [sem a] sua família

C: isso... sem minha família..." (CS20, Anexo, p. 5, grifo nosso)

Outro aspecto que se pode depreender a partir dessa declaração é que "a família", de certo modo, remete a um ator discursivo que precisou ser "superado" na aquisição de independência. Em termos narrativos, pode-se dizer que os valores da família (antidestinador) são diferentes dos valores da jovem (sujeito), e que esta, em alguma medida, toma a ausência da primeira como um momento adequado para que emancipação possa acontecer. Em outras palavras, pode-se dizer que, para a obtenção de mais liberdade na vida, há a necessidade de extrapolação da espacialidade na qual reside o ator representado pela instituição social, ainda que mediante outro tipo de acompanhamento (de amigos e colegas, no caso).

Ainda que se declare uma jovem independente, vê-se que, do ponto de vista geográfico, os deslocamentos mencionados por CS20 são de extensão relativamente menor que os dos demais entrevistados. Vale lembrar que, dentro do tema da exploração de territórios diferentes, AV24 menciona idas ao centro da cidade e a outros Estados do país e que SM28 deixa, sozinha, a pequena cidade natal para viver em São Paulo. O deslocamento de CS20 dá-se apenas entre bairros de uma mesma cidade. Por outro lado, ela é a mais jovem dos entrevistados, o que poderia explicar a sua maior proximidade dos pais. 
Além disso, conclui-se que há uma diferenciação quanto ao investimento discursivo e ao modo de enunciar dos diferentes entrevistados. O depoimento de AV24 vale-se da primeira pessoa do singular e da locução pronominal "a gente" (significando a primeira pessoa do plural) para fazer considerações sobre a juventude de modo geral. CS20, em sua fala, utiliza também as construções da primeira pessoa, mas designa, com essa estrutura, apenas a ela mesma.

A partir dessa constatação, lança-se a hipótese de que os discursos dos jovens que se encontram envolvidos em organizações sociais ou em instituições políticas e do terceiro setor possuem a tendência de tratar emancipação como um fenômeno coletivo, mesclando suas falas pessoais com o discurso das organizações nas quais estão envolvidos. Os relatos daqueles que não pertencem ou atuam no âmbito desse tipo de entidades, como CS20 (que trabalha com cultura e no setor de serviço), tendem a tratar o tema com uma actorialização mais individualizada. A primeira tendência é visível na fala de AV24.

“E: (...) que atitude você faz no seu dia-a-dia para se manter independente?

A: a gente cria sistemas em nosso favor entendeu?... se eu estou farto de um sistema de violência e opressão eu vou criar um sistema que é essa casa que é um sistema de amor e paz tá ligado?... (...) se eu estou insatisfeito com o sistema capitalista e eu quero construir uma economia que de fato me representa... há quatro anos a gente desenvolve um banco comunitário..." (Anexo, AV24, p. 2, grifos nossos)

O trecho acima, que ilustra a influência que as práticas do coletivo político e social de AV24 têm sobre sua vida, traz um exemplo nítido de uso de estruturas actoriais coletivas. No caso, vê-se que, embora as figuras relacionadas à necessidade, falta ou insatisfação sejam "sentidas" por um ator designado pela primeira pessoa do singular, o interesse de todos os jovens de periferia parecem estar incluídos nele. A locução "a gente", utilizada em dois momentos no trecho, revela que essas duas instâncias actoriais ("eu" e "demais jovens") são representadas como se pertencessem a "um mesmo corpo". Esse agiria, também, de maneira singularizada, na direção da criação dos "sistemas em nosso favor". A tendência constatada remete a um senso de coletividade e engajamento que o enunciador procura deixar evidente em sua entrevista. Isso não significa, contudo, que outras maneiras de se discursivizar a militância não sejam possíveis (tais como aquelas que se valem de atores mais individualizados, por exemplo).

Os indivíduos que falam mais em nome de si mesmos, e menos em nome de instituições ou organizações, no corpus do presente estudo, representados em especial por CS20, padecem e beneficiam-se dos frutos de suas ações de maneira mais direta. Essa tendência parece 
encontrar eco em algumas das análises sociológicas que estudam a pós-modernidade e a condição dos jovens nos dias atuais, como a realizada por Pimenta (2007).

Em sua tese, apresentada ao Departamento de Sociologia da USP, sobre a etapa de transição à adultez, citando Manuela Du-Bois Reymond e Andreu López Blasco, a autora trata da ideia de que os percursos biográficos dos jovens dos dias de hoje estão cada vez mais individualizados e isso implica no fato de que devem "construir sua própria biografia sem depender da estabilidade dos contextos ou das tradições nas quais se movem" (p. 107). Um pouco antes, para explicar a mudança, a autora se valera de uma descrição metafórica, que associava o processo de transição à vida adulta anterior à década de 1960 a uma viagem de trem, enquanto a mesma passagem, a partir de 1980, podia ser vinculada a uma viagem de carro.

\footnotetext{
“Na década de 1960, uma das metáforas utilizadas (72) para descrevê-las eram as viagens de trem: ao iniciarem a educação compulsória, os jovens embarcariam em um comboio, cujo destino era determinado por fatores tais como a classe social, o gênero e o nível educacional atingido. Os destinos possiveis também eram limitados e, uma vez iniciada a viagem, era difícil mudar de trem e seguir noutra direção. A partir da década de 1980, entretanto, as trajetórias passariam a ser descritas como viagens de automóvel, em que cabe ao motorista escolher o caminho a seguir" (Pimenta, 2007, p. 106, grifos nossos)
}

A metáfora, em termos aspectuais, explora a alternância entre o modo durativo contínuo (viagem de trem) e o modo durativo descontínuo (Barros, 2002, p. 91), viagem de carro. Ao mesmo tempo em que o trajeto de um jovem em 1960 é representado como uma viagem longa e ininterrupta, cujo destino era apontado com relativa precisão pelos fatores socioeconômicos mencionados, o indivíduo que se movimenta em direção à idade adulta a partir da década de 1980 se vê diante de uma viagem igualmente distante, porém, bem mais sujeita às intempéries do tempo, das perdas e reformulações de rota e - talvez o mais importante - das vontades e decisões do motorista. A diferença diz respeito, essencialmente, à relação entre a abertura e o fechamento de oportunidades e às interrupções que cada trajeto pressupõe, fazendo analogia com os percursos dos jovens em cada período, sempre determinados pelas variantes sociais que lhe são específicas.

As particularidades enunciativas e discursivas encontradas nos textos aqui analisados aproximam-se de ambos os perfis propostos por Pimenta. A observação das categorias sociológicas sugere que os processos de transição mais individualizados estariam associados ao modo da "viagem de automóvel", típico da contemporaneidade. Por outro lado, a emancipação 
mais coletiva estaria, talvez, mais próxima ao percurso do trem, e menos sujeita às interrupções e mudanças de rumo da vida pós-moderna.

\subsection{Introspecção e extroversão}

Para investigar de modo mais aprofundado as diferenças conceituais da independência presente no discurso dos outros dois entrevistados (SM28 e JS23), os critérios que os classificam em actorialidades individualizadas ou coletivas precisam ser extrapolados. A isotopia da introspecção é outro ponto a ser considerado. Ao responder à questão "o que significa para você viver a própria vida?", SM28 mostra uma concepção de independência que não havia sido verificada nos discursos até aqui observados. Afirma que o movimento de ganho de emancipação em sua vida, fenômeno gradual e durativo, aumenta na mesma direção do conhecimento a respeito de sua interioridade.

“é um pouco de:... primeiro... me conhecer né... quais quais as / as minhas: / as minhas vontades os meus desejos que eu gosto que eu não gosto (então eu estou) muito ness / ness / nesse momento agora de de: de encontrAR de me encontrar e de encontrar o que que eu vou fazer daqui para a frente... e:... e respeitar isso... e outra coisa é de também valorizar o que que:... o que que: o universo... o que que:.. o que que a minha intuição está pedindo..." (Anexo, SM28, p. 19, grifos nossos)

Observando-se esse trecho com certa atenção, pode-se verificar que o ato de se tornar independente corresponde, em certa medida, para SM28, a uma reflexão sobre a própria subjetividade. O aprofundamento em um caminho de autoinvestigação é o que levaria a entrevistada à emancipação. Figuras de sensibilidade (expressas pelos termos "me conhecer" e "intuição") encontram-se nesse regime de conhecimento. Ao se ver como alguém que ignora determinados aspectos de sua personalidade (ideia expressa pela frase "quais as / as minhas: (...) vontades os meus desejos que eu gosto que eu não gosto"), SM28 talvez esteja referindose ao inconsciente, ou, grosso modo, à parcela de subjetividade oculta que nem os próprios sujeitos têm consciência de existir, identificada por Freud no âmbito da Psicanálise e desenvolvida por seus seguidores ${ }^{19}$.

Além de declarar estar vivendo um processo de autoconhecimento, a própria entrevistada, um pouco antes na sua fala, tinha dito que "ser livre para mim... é:... é muito

\footnotetext{
${ }^{19}$ Os pontos de contato e alguns dos possíveis desdobramentos que a teoria psicanalítica pode ter sobre a semiótica (e vice-versa) foram explorados por Beividas (2002), que afirma que as duas áreas do conhecimento deveriam ser mais próximas.
} 
difícil... ser livre né? porque... (...) a minha liberdade depende da / do limite do outro né? dessas barreiras..." (Anexo, SM28, p. 18, grifo nosso). Ou seja, ao mesmo tempo em que afirma a importância de um olhar individualizado e ciente de si para o estabelecimento da independência, SM28 reconhece o valor da inserção social, em especial, no que diz respeito aos limites que o "eu" possui diante da convivência com os "outros". Como observado na introdução desta dissertação, a liberdade dos sujeitos deve sempre ser vista com relação à dos demais. Nesse momento, o ator sai do campo semântico da introspecção para ingressar novamente naquele das relações sociais. Mais uma vez, vê-se um movimento dialógico no discurso dessa entrevistada, que combina os elementos interiores e exteriores ao indivíduo, quando falando da construção de sua emancipação.

JS23 considera que a independência é uma ação que precisa ser executada pelo próprio indivíduo. Vê-se aqui uma aproximação ao discurso de SM28, pois ambos os textos associam o movimento emancipatório à busca de um "querer" pessoal ("querer sonhar o seu sonho e ir em busca dele...", Anexo, JS23, p. 9, grifo nosso). Por outro lado, o primeiro refere-se ao fenômeno como algo vindo de pessoas que sabem o que querem e que se dispõem a alcançar esses objetivos por meio de suas atitudes. Nesse sentido, ele não se detém tanto na isotopia da introspeç̧ão, da busca interior, estando mais no campo da extroversão e das ações. $O$ trajeto referido pelo discurso de JS23 é mais "observável" do que aquele presente na fala de SM28, que se refere a um caminho, sob certa perspectiva, menos delimitado.

Recuperando a metáfora proposta por Du-Bois Reymond e Blasco (citada por Pimenta, p. 107), JS23 seria mais adepto da "viagem de trem" do que a entrevistada mencionada anteriormente, embora, de maneira geral, possa ser considerado, ainda assim, mais um "viajante de carro" que um passageiro desse comboio atribuído aos jovens da década de 60, como se verifica a partir da leitura completa de seu depoimento.

O entrevistado conta que sua motivação não se funda apenas nos elementos que vêm de sua individualidade, mas também na admiração que recebe de outros jovens que o veem e que se inspiram em seu modelo. Diz, "eu pago as minhas contas eu sonho os meus sonhos assim... mas você se sente bem quando você vê a / algo: / tipo: que:... alguém / algum outro jovem olha para você e fala 'pô... se você conseguiu eu também consigo chegar lá...'" (Anexo, JS23, p. 10, grifo nosso). Essa noção, que remete à influência de actantes narrativos sobre o sujeito do fazer, pode ser mais bem explorada a partir das noções de manipulação e sanção narrativas, e será tratada no capítulo seguinte ("3. Narratividade da emancipação nas entrevistas").

Além de receber a motivação que vem da inspiração de outros jovens no modelo que ele fornece, JS23 descreve euforicamente a ação de outras pessoas, mais experientes que ele, 
que souberam multiplicar os seus campos de ação e práticas por meio da formação, admirandoas.

“multiplicar... criar multi / é: criar multiplicadores do que ele FAz... para mim eu acho que isso é... / está:... muito bem dito na capoeira... que nem... mestre bimba é isso... ele criou muitos multiplicadores... a capoeira... de angola tambÉM... você vê muita gente que são / assim... muita gente que são multi / tem / tem poucos espaços de capoeira de angola mas:... tem multiplicadores da capoeira... hoje o Brasil está buscando isso... que é a... / é a mesma coisa que o futebol... o futebol você vê milhares de multiplicadores" (Anexo, JS23, p. 14, grifos nossos)

No trecho selecionado, vê-se como os universos da capoeira e do futebol são eleitos por esse entrevistado como lugares exemplares para se falar de êxito quanto à temática da multiplicação de práticas, evocando a figura de Mestre Bimba, o criador da capoeira regional, da qual teria sido também um grande difusor. A avaliação que o discurso de JS23 faz dos indivíduos que conseguem agir como multiplicadores de práticas, profissões ou mesmo cultura é eufórica, e encontra eco nos discursos de outros entrevistados, como SM28, que valorizam as ações de transformação social e sua disseminação na sociedade de modo geral.

\subsection{Engajamento e transformação social}

Depois de investigadas algumas das associações dos discursos de dois entrevistados no que tange a suas espacializações, temporalizações, actorializações e, também, às isotopias da introspecção e da extroversão, é interessante verificar em que medida a ideia de engajamento influencia a conceituação de independência de cada um deles.

Para dar início, SM28 considera que a juventude é um período de inquietude por excelência, e que essa etapa encontra-se intimamente ligada com o ativismo social.

“... juventude não está muito ligado a... / a idade... eu... acho sim que / que um determinado: tempo da nossa história de vida a gente tem uma maior vitalidade uma maior alegria um:... um... um desperTAR para as coisas para fazer as coisas para estar em movimento para mim juventude é isso... ser jovem é isso é:... estar: em movimen:to é provocando algumas situações instigando... e:... acho que uma coisa que: / que eu vejo nos outros jovens e até mesmo em mim... é a teimosia né então... teimosia de de buscar determinadas coisas teimosia de $a$ / de acrediTAR em coisas que:... às vezes em... em outros 
pontos da vida não não acredito juventude é isso... muito a ver com o pulsar da vida..." (Anexo, SM28, p. 16, grifos nossos)

A fala de SM28 associa a disposição e vitalidade pessoais ao tema do engajamento e da luta pela transformação da realidade social. Além disso, associa "ser jovem" a um "estado de alma", descartando a conceituação da juventude meramente como faixa etária. Pimenta também verifica uma tendência entre os jovens que entrevistou (por meio da metodologia de grupos focais ${ }^{20}$ ) a considerar essa etapa como um “'estado de espírito' que 'não tem nada a ver com a idade'" (p. 144, grifos da autora). Os seus informantes tinham entre 25 e 30 anos (p. 47). Mas os conceitos de juventude encontrados por ela diferem do que se depreende a partir do discurso de SM28, pois não remetem primordialmente a um estado de inquietação das pessoas, mas, sim, a um elemento relacionado com o que se denomina modalidade narrativa do querer.

“É interessante observar que a maior parte dessas práticas ditas "juvenis" está associada a atividades de lazer e de consumo, tais como "sair" (pra balada, pro salão, pro pagode, pra dançar, para o bar, para o cinema), "viajar", "acampar", "praticar esportes", "gastar dinheiro", entre muitas outras. O mais importante, porém, é que elas adquirem sua conotação positiva quando colocadas em oposição às chamadas práticas não-juvenis ou "atitudes de velho"." (Pimenta, 2007, p. 145, grifos da autora)

Vale menção especial o fato de que o discurso desses entrevistados parece construir uma noção idônea de juventude ao mesmo tempo em que disforiza o conceito de adultez. É como se, ao identificar o ser jovem com os valores associados ao querer, o ser adulto, por sua vez, apenas pudesse desempenhar suas ações com base na modalidade do dever, menos prazerosa que a primeira.

Ainda segundo Pimenta, se a juventude, para esses jovens, por um lado, goza de um lugar privilegiado no sentido de prover os indivíduos com a satisfação de muitos de seus desejos, a etapa da adolescência, por outro, toma um aspecto sumamente disfórico (p. 143). Assinala que ser adolescente, para esses sujeitos, é estar em um período de conflitos e crise interna e em um momento de indefinição, no qual o indivíduo não pode usufruir as despreocupações da infância e nem os poderes da adultez. Essas desvantagens sentem-se ainda mais, afirma a

${ }^{20} \mathrm{O}$ método de pesquisa social qualitativo conta com um objetivo definido e um número limitado de perguntas ou temas, colocados por um moderador que coordena o procedimento e garante que todos os envolvidos participem igualmente (Pimenta, 2007, p. 44, citando David Morgan, "Focus Group as Qualitative Research"). 
autora, nos segmentos menos favorecidos da sociedade. Isso acontece, segundo ela, por alguns fatores, descritos abaixo.

"É interessante observar que, tanto entre os homens, quanto as mulheres, os participantes expuseram e discutiram as dificuldades de ser adolescente na periferia nos dias de hoje, seja pelas dificuldades econômicas que empurram meninos e meninas mais cedo para o trabalho, seja pela falta de espaços e oportunidades de lazer, o que, juntamente com o crescimento acelerado e caótico da metrópole avança contra essa etapa da vida no sentido de ameaçar suprimi-la" (Pimenta, 2007, pp. 141-142).

Os entrevistados no âmbito do presente trabalho não se pronunciaram quanto às diferenças existentes entre a adolescência e a juventude. Além disso, distinguem-se do perfil encontrado por Pimenta, pois falam de juventude como um momento de inquietude social e militância pela transformação das suas realidades, não se detendo muito nos temas e figuras relacionados ao querer-fazer, que foram constatados pela autora (p. 143). Tal discrepância, provavelmente, deve-se ao critério de seleção de entrevistados desta dissertação, que exigia no perfil dos seus informantes a atuação em projetos pessoais de caráter transformador ou inovador no sentido da emancipação social ou cultural. Por outro lado, o perfil socioeconômico dos entrevistados deste trabalho é próximo ao dos grupos G3 e G4 do estudo de Pimenta (p. 48).

Imanishi (2008, p. 22), do Instituto de Psicologia, em sua dissertação de mestrado, trata da problemática que chama "idealização da adolescência". Nesse sentido, vai além da visão mencionada acima, que confere disforia à adolescência e euforia à juventude, constatada por Pimenta (2007, p. 143). Na passagem citada de seu trabalho, a autora refere-se ao que considera uma mitificação da etapa anterior à adultez e procura justificar, por meio da análise de algumas obras de autores como Philippe Ariès e Edgar Morin, o seu estatuto idealizado. O lugar do jovem é visto como o almejado e o posto do adulto "fica reservado àquilo que é da ordem do indesejável, do ultrapassado" (2008, p. 23). Isso se dá no contexto de uma sociedade contemporânea, de consumo, na qual o veloz e o novo são privilegiados em detrimento do tradicional. A abrangência dessas afirmações faz com que as reflexões a respeito da juventude ganhem outro matiz e, assim, as problemáticas concernentes a esse segmento, ao serem discutidas nos dias de hoje, adquirem um teor mais aprofundado.

Postas essas considerações de lado, e retomando a análise do presente corpus, a partir do que se verificou nos relatos de AV24, JS23 e SM28, pode-se afirmar que há, nas falas dos entrevistados em geral, dois modos diferentes de se discursivizar engajamento e o desejo de 
transformação social. Um deles pauta-se por um investimento coletivo de atores com interesses convergentes, formando um bloco coeso que age para a consecução de um objetivo (verificada, sobretudo, em AV24). A segunda maneira dá-se pelo investimento de um ator individualizado (tal como se verifica em SM28 e JS23). Cada qual pauta-se pelo estabelecimento do que se denomina, no nível narrativo, um contrato fiduciário, sendo apoiado majoritariamente em fontes exógenas ao sujeito (no primeiro caso) ou endógenas dele (no segundo caso). Tanto em um modo como no outro, há manipulação narrativa. Ela está investida em cada caso por manifestações discursivas diferentes, tais como a admiração que os indivíduos jovens sentem diante de outras pessoas mais experientes ou a autoconfiança. Os atores que investem o papel de destinador são normalmente profissionais bem-sucedidos (jogadores de futebol, capoeiristas), membros da família (pais), mestres ou ainda os próprios jovens (no caso de manipulação reflexiva). O discurso de CS20, dentre os casos analisados é o que menos encontra pontos de comparação com os demais por não chegar a abordar com profundidade a temática política.

\subsection{Família e o mundo dos adultos}

Analisando-se os discursos a partir do tema da família, de uma maneira geral, vê-se que os entrevistados mencionam as respectivas famílias nucleares como pontos de partida, ou dependências prévias, a partir das quais é necessário que se faça um movimento de saída para que se possam buscar os interesses concernentes a uma vida própria. Isso vai ao encontro de critérios sociológicos amplamente utilizados na metodologia de estudos da transição e da juventude, que reconhecem no abandono do lar de origem, entre outros pontos, um marco na passagem da vida jovem para a vida adulta (Pimenta, 2007, p. 26).

A extensão do período de permanência dos jovens na casa dos pais (tendência crescente em nível mundial, 2007, p. 20) exige uma relativização quanto à noção tradicional dessa passagem. Se, por um lado, há jovens que ainda não abandonaram a casa dos pais, porque não conseguiram estabelecer-se profissionalmente e, por conseguinte, não possuem recursos para viabilizar tal saída, há aqueles que, embora sejam independentes financeiramente, não deixam a morada da família, por razões variadas (p. 19). As motivações pelas quais um indivíduo permanece na casa dos pais, abandona-a ou retorna ao antigo lar, hoje, não são as mesmas que há algumas décadas. Uma concepção de juventude que tenha a condição de responder às novas disposições tem sido discutida entre os sociólogos da área, na busca de uma maior compreensão sobre essas variáveis. 
Para entender um pouco melhor a problemática, Pimenta, citando José Machado Pais, traz algumas palavras que descrevem as dimensões da mudança pela qual os jovens têm passado a partir dos anos 90.

\footnotetext{
"As tradicionais distinções entre o estudante e o não estudante, o trabalhador e o não trabalhador, o solteiro e o casado dão lugar a novos estatutos intermediários e reversíveis, mais ou menos transitórios e precários (Pais, 1994) e a estilos de vida mais flexíveis, que combinam trabalho e estudo, trabalho e lazer" (2007, p. 94)
}

A flexibilização, mencionada no nível do trabalho, do casamento e da formação escolar, atinge também o nível da família, cujas relações vêm tornando-se mais variadas em suas naturezas e em suas possibilidades de estabelecimento (casamento homossexual, famílias constituídas por pais ou mães solteiros[as], por exemplo). Diante das novas configurações, os jovens também parecem expressar certa tendência a outros modos de comportamento. 0 prolongamento da vida no lar familiar seria uma dessas manifestações.

Outro fator que instiga a permanência na casa dos pais é a instabilidade que se verifica na esfera do trabalho, decorrente, entre outras coisas, da inconstância econômica do atual sistema, incorrendo na transferência de valores de incerteza para aqueles que desejam integrarse ao mercado (Imanishi, 2008, p. 45). Além disso, com a queda do modelo do Estado do bemestar social e a flexibilização da mão-de-obra, dos locais de produção e do próprio capital, hoje é mais difícil a elaboração de um projeto de vida e de um planejamento a longo prazo no âmbito pessoal (p. 46). Os jovens, por sua vez, veem-se diante de uma constante necessidade de reavaliação e adaptação, em uma esfera de competição que, muitas vezes, significa pressão para que sejam "proativos, criativos, seguros, determinados e, porque não, infalíveis" (p. 45). Diante dessa atmosfera é que se justifica a recusa da juventude dos dias de hoje a deixar os lares paternos e maternos. Mesmo assim, é necessário compreender cada caso em sua particularidade, e, embora essa seja uma tendência que permeia os jovens da pós-modernidade de um modo geral, certamente há exceções.

Pimenta relembra que uma família também pode depender do jovem em muitos aspectos, pois, a despeito da ideia (que parece ser a única possibilidade) que atribui a dependência como vindo dos jovens a seus pais, há casos nos quais o laço de dependência realiza-se no fluxo oposto (2007, p. 69). 
Imanishi entrevistou 520 alunos do Ensino Médio de São Paulo (2008, pp. 77-78) ${ }^{21}$. Dentre as respostas de múltipla escolha que aplicou, constavam avaliações realizadas pelos jovens sobre o modo como os adultos de hoje dirigem o mundo. No total das respostas obtidas, $27,5 \%$ dos que responderam à pesquisa consideraram que os adultos dirigem bem o mundo, $48,65 \%$ afirmaram que eles o dirigem mal e $22,69 \%$ assinalaram que realizam essa tarefa muito mal. A autora do estudo considera que há um pessimismo com relação à avaliação da capacidade dos adultos de serem responsáveis pelo mundo.

Se esse fato for observado com relação à natureza da escola, verifica-se que "os sujeitos das particulares foram significativamente mais críticos em relação a essa avaliação: $85 \%$ consideraram que os adultos dirigem mal ou muito mal, enquanto esta porcentagem caiu para $56 \%$ entre os alunos de escolas públicas". Por um lado, vê-se que os adultos são majoritariamente mal avaliados, por outro, há um percentual considerável de jovens de escola pública (41,99\%) que avaliam que eles o dirigem bem . Ou seja, a sanção negativa dos jovens da educação privada encontra certo contraponto no grupo de entrevistados oriundo das instituições do governo que, sim, acreditam (em certa medida) na capacidade dos adultos de dirigir o mundo.

Nesse sentido, e voltando aos dados do presente estudo, em se observando o fato de que os jovens entrevistados no âmbito desta dissertação passaram todos por escolas públicas, vê-se que há uma convergência entre os resultados aqui obtidos e os dados mencionados acima. Em ambos os casos, há euforia e disforia no que tange à avaliação dos integrantes do "mundo dos adultos". No corpus deste trabalho, analisando-se em especial a figura dos pais, os entrevistados também a julgam de maneira ora positiva e ora negativa em seus depoimentos.

$\mathrm{Na}$ análise feita anteriormente neste capítulo, apontou-se que o tema família foi depreendido como eufórico e disfórico, tanto para os entrevistados do trabalho de Harkot-deLa-Taille e Bariaud, quanto para os do presente estudo. Diante dessa constatação, endossa-se a hipótese de que há um regime dialógico entre relacionamento familiar e independência no discurso dos jovens de São Paulo. Os entrevistados não veem a vida em família e a vida emancipada como caminhos necessariamente excludentes e reconhecem que a interferência de uma na dinâmica da outra, por vezes, pode se dar sem inconvenientes. Ao mesmo tempo, a saída do lar familiar é um "degrau" no caminho da emancipação que é almejado por todos.

Como visto, os jovens que concederam entrevista ao presente estudo, de maneira geral, não veem a proximidade das suas famílias como um impeditivo à emancipação. JS23, por

\footnotetext{
${ }^{21}$ Trata-se de um interessante estudo realizado a partir dos dados obtidos com a aplicação questionários com alunos de escolas públicas e particulares da cidade de São Paulo. As perguntas dividiram-se entre dissertativas e de múltipla escolha.
} 
exemplo, em trecho já mencionado, relativiza a importância que residir na casa de familiares possui para ele e para a constituição de seu senso de independência. Como visto, diz que ser independente é poder sonhar os próprios sonhos e "não o estar dentro da casa da mãe, ou o estar dentro da casa do pai ou do tio" (Anexo, JS23, p. 9).

CS20, por sua vez, vê com tranquilidade a possibilidade de permanecer na casa de sua mãe por mais uns anos, embora dê importância ao fato de ser independente. No trecho abaixo, relata que pretende morar por mais um tempo onde está e só depois mudar de casa.

“C: eu pretendo... por enquanto eu pretendo ficar lá na casa da minha mãe... onde eu estou lá... depois... seguir a minha vida adiante... né?... porque:: ser independente é muito imporTANte... na nossa vida... é isso

E: mas você acha que:... vai sair um dia ou você acha que:: você pode continuar lá?

C: lá eu acho que eu posso continuar...

E: pode?...

C: posso... eu posso continuar lá mas... um dia eu sei que eu vou ter que sair... que sair... e viver a minha vida né?... como uma pessoa independente... é isso..." (Anexo, CS20, pp. 7-8, grifo nosso)

Ao ressaltar a importância de reconhecer o momento do abandono do lar familiar de origem para uma compreensão mais profunda dos processos de transição para a vida adulta no Brasil, Pimenta (p. 26) também conta que essa variável é apenas uma de cinco. As outras são a trajetória escolar, a inserção na vida ativa, a qualidade das ocupações e a constituição de uma nova família, segundo propõe em seu estudo sobre as representações, identidades e trajetórias de jovens no país.

Para encerrar a análise do nível discursivo das entrevistas coletadas, é possível realizar, ainda, algumas considerações a título do estabelecimento de um diálogo entre as etapas de análise. Em primeiro lugar, é interessante pontuar que, no nível discursivo, o investimento actorial do sujeito não se encontra necessariamente atrelado à articulação fórica do tema da transformação social. Ou seja, não é porque o sujeito é investido com um ator individual que ele deixa de manifestar euforia diante desse tema. Assim, SM28 e JS23, por exemplo, a despeito de se referirem euforicamente à luta pela alteração das realidades nas quais vivem, utilizam estruturas linguísticas individualizadas em seus discursos.

Ainda no que diz respeito à relação entre actorialização e tematização, vê-se que existe a tendência de que alguns temas sejam mais usados por narradores que se valem de atores individuais, e, outros, por narradores que usam atores coletivos para expressar suas ideias. 
Assim, medo, rejeição, ensimesmamento, tristeza, dúvida, beleza e conhecimento são exemplos de temas predominantemente individuais. Por sua vez, os temas pressão social, segregação, perda, convívio e colaboração tendem mais à actorialização coletiva (alguns deles por razões óbvias).

No que toca à temporalização, é interessante observar que CS20 foi a única que considerou independência um fenômeno pontual e que se declarou plenamente "independente". Além dessas particularidades discursivas, essa entrevistada destaca-se por ser a mais jovem do corpus e por ser somente ela que trabalha no setor de prestação de serviços, não tendo qualquer envolvimento profissional com organizações do terceiro setor. Os demais concebem independência como um fenômeno durativo e não terminado. Além disso, SM28, AV24 e JS23 trabalhavam, no momento de concessão das entrevistas, em ONGs ou associações. No cruzamento do critério da espacialização com a figura da família, viu-se que a saída da casa dos pais durante a etapa da juventude geralmente não é vista como imprescindível para a obtenção de independência nos discursos do corpus. As viagens e as saídas ou passeios (eufóricas) constituem o principal mecanismo de expansão territorial dos sujeitos. 


\section{Narratividade da emancipação nas entrevistas}

Após o estudo das manifestações discursivas presentes no corpus, seu nível pressuposto, a narratividade, pode trazer outra luz à análise. Dividido em dois tópicos, ("3.1 Manipulação" e "3.2 Virtualização e atualização nas entrevistas") o presente capítulo busca dar conta das condições que levam à realização narrativa, entendendo que o olhar dedicado a cada uma das etapas mencionadas fornece uma compreensão mais apurada do sentido de emancipação. Cada momento de análise exige a utilização de um instrumental teórico que seja pertinente para a abordagem. Muito embora o foco esteja agora no nível narrativo, as relações com os outros níveis (discursivo e tensivo) são também levadas em consideração, sempre que trouxerem mais clareza aos pontos abordados.

Os postulados que se referem ao nível da narratividade tratam de estruturações de sentido mais profundas do que as estudadas até o momento. Nesse sentido, passa-se a trabalhar com articulações ainda mais generalizáveis do que as precedentes. Para isso, o percurso narrativo do sujeito é levado em conta, com a tarefa de se depreender os principais mecanismos pelos quais ele adquire conjunção com os valores ligados à emancipação (em última instância, o poder-fazer e o poder-não-fazer, Greimas e Courtés, 2012, p. 362). Mesmo estando esses valores localizados na etapa da atualização, não interessa à presente dissertação o estudo de uma parcela isolada da emancipação, mas, sim, ela como um todo, estando as outras categorias modais (querer, dever e saber) também em jogo na análise. A própria modalidade do poder, se vista pela complementaridade que partilha com a do dever (que parece ora afirmar, ora negar a distância entre as duas), já aponta para a existência de uma permeabilidade entre os domínios da atualização e da virtualização, e vice-versa.

Para a observação dos fenômenos da emancipação, são utilizadas, neste capítulo, as quatro etapas do esquema de presença, tal como ele foi formulado por Fontanille e Zilberberg, a saber, realização, potencialização, virtualização e atualização (2001, p. 256, verbete "modalidade"). Essa formulação é amplamente reconhecida na semiótica dos dias atuais, tendo aderido a ela autores como Fiorin (2012, p. 120) e Tatit (2010, p. 53), entre outros. As etapas da manipulação e da sanção, igualmente elucidativas para uma compreensão mais apurada dos fenômenos de significação, também recebem atenção especial, sobretudo no primeiro tópico da seção.

A diferenciação entre os conceitos fazer normativo e fazer avaliativo, proposta por Zilberberg, é utilizada aqui para o enriquecimento do tratamento das etapas da potencialização e da manipulação (2006, pp. 152-153). Estes dois movimentos foram reconhecidos pelo autor 
como presentes na constituição do espaço fiduciário. A diferenciação entre eles auxilia a entender mais detalhadamente a caracterização do contrato do sujeito.

Além disso, dentro do mesmo assunto, a abordagem da obra já citada de Fontanille e Zilberberg traz considerações sobre o espaço da fidúcia e é também adotada no âmbito deste estudo (p. 265). A reflexão dos autores o reconhece como um lugar de "acolhimento das valências", dividido entre a confiança (intersubjetiva) e a crença (em objetos). Essa distinção é pertinente do ponto de vista metodológico, pois diferencia o fazer sobre o mundo do fazer do sujeito sobre outro sujeito, trazendo, assim, mais operacionalidade ao aparato da categoria potencial.

\subsection{Manipulação}

A manipulação, concebida como etapa na qual se dá a transmissão de valores modais do destinador ao destinatário, é indispensável para a compreensão do fenômeno da emancipação do ponto de vista narrativo. Nos percursos trazidos pelas entrevistas, verifica-se a presença de dois grandes tipos de manipulação, aquelas de natureza transitiva, nas quais há dois atores distintos recobrindo, cada qual, um papel actancial diferente (destinador e destinatário); e as reflexivas, nas quais há sincretismo actancial (apenas um ator para os dois papéis), como visto nos capítulos anteriores.

Além de variar por sua dinâmica interna, os programas de manipulação encontrados no âmbito do presente trabalho apresentam uma diferença no que se refere à articulação dentro do percurso narrativo do sujeito, que descreve a conexão que há entre PNs. Assim, considerase que existe uma manipulação instauradora (a partir da qual o ato emancipatório acontece), e outra "finalizada-instauradora", que se vale da sanção positiva do destinador-julgador para desencadear, em seguida, a manipulação de programas subsequentes. Em primeiro lugar, tratase aqui da instauradora para, ao final do tópico, dirigir-se atenção à manipulação fundada na sanção. 


\subsubsection{Manipulação instauradora}

Cada jovem tem um modo próprio de entender o que significa independência, liberdade, autonomia e emancipação em sua vida. Alguns deles concebem essa passagem como um fenômeno acabado, ao passo que outros a veem como um processo em curso. Ao mesmo tempo em que há entrevistados que dizem levar anos para tornarem-se independentes, outros afirmam que isso corresponde a uma passagem breve. Daí resulta que é impossível atribuir uma aspectualidade única para a descrição de todos eles.

Quando falam sobre seus processos de independência (aquisição de valores narrativos), os jovens realizam descrições a respeito de suas trajetórias. Segundo o instrumental teórico, o discurso, nesses momentos, aproxima-se do que se denomina fazer avaliativo. Do ponto de vista do objeto, esse tipo de ação discute "as vantagens dos objetos e os méritos dos sujeitos" (Zilberberg, 2006, p. 153). Outra possibilidade de descrição teórica, seria a sanção pragmática ou cognitiva, respectivamente, um juízo sobre o fazer ou sobre o ser (Greimas e Courtés, 2012, pp. 426-427). Essas duas visões de um só fenômeno de significação vêm da teoria semiótica e podem ser vistas em complementaridade. Quanto a essa questão, é essencial que se observe, por exemplo, não apenas se o entrevistado declara-se independente ou não, mas as razões pelas quais justifica tal afirmação. Assim, torna-se possível depreender o sistema axiológico no qual se baseiam as suas asserções e obter uma ideia mais elaborada a respeito do tipo de emancipação que se está diante.

No que tange à aspectualidade da manipulação encontrada nos textos, pode-se dizer que ela é vista como fenômeno processual e durativo (tendência mais presente nos depoimentos de SM28 e CS20) ou como passagem pontual e repentina (como prepondera em AV24 e JS23). Como exemplo textual da última maneira de emancipar-se (uma fugaz etapa de interação do destinatário com o destinador), aqui vai esse trecho de depoimento: "de repente você vê que você está... saindo de casa... está: está: fazendo uma faculdade por conta própria está pagando as suas contas..." (Anexo, JS23, p. 9, grifo nosso). O entrevistado demonstra espanto diante da velocidade da chegada desses elementos que investem um marco inicial na aquisição de liberdade e independência por parte do sujeito narrativo. Antes de exteriorizar essa surpresa diante das próprias capacidades, o entrevistado vinha dizendo que seus pais the cobravam de maneira exagerada. 


\subsubsection{Manipulação reflexiva}

No depoimento dos entrevistados, de modo geral, observa-se que os relatos que tratam de emancipação muitas vezes iniciam-se por uma motivação que se pode chamar reflexiva. Muito embora não seja a única forma de construção que rege a etapa de transmissão de valores modais (pois a transitividade também encontra-se presente em algumas das passagens do corpus), o sincretismo actancial parece ocupar uma posição-chave no que toca à construção do senso de independência dos sujeitos.

Os entrevistados que se dizem mais "responsáveis" por suas próprias ações (manipulação reflexiva) usam construções linguísticas também mais pautadas na assertividade. Por vezes consideram que a independência é um processo que, no momento da narração, já se encontra completo (ou quase), como um ciclo praticamente cumprido em suas vidas. CS20 e JS23 são os que declaram estar mais próximos disso. O segundo deles afirma a importância de a própria subjetividade ser fonte de inspiração para os projetos futuros (Anexo, JS23, p. 9). Pouco antes na mesma entrevista, havia afirmado considerar a si próprio como uma pessoa independente. Seu discurso estabelece, no nível narrativo, um percurso a partir da negação da manipulação oferecida pelo antidestinador ("pais"). O querer-fazer do sujeito investido por JS23 também parece encontrar uma fonte de motivação em outro PN, fracassado, investido pelo mesmo ator da manipulação. Nesse programa anterior, o sujeito ("seus pais") não pôde entrar em conjunção com o objeto ("experiências de progresso variadas"). A influência de um PN fracassado sobre outro, que acontece na sua sequência, será observada com mais detalhe adiante no presente capítulo.

Se, por um lado, o entrevistado nega o legado familiar, por outro, as forças que fazem com que possa tornar-se independente também encontram certa influência positiva vinda de seus parentes. No trecho da entrevista que está transcrito abaixo, JS23 reconhece que, na busca do seu caminho de vida, o que os pais puderam lhe proporcionar também Ihe trouxe benefícios.

“E: (...) o que você busca... é: ou buscava quando você: estava começando a procurar mais / ter mais liberdade e autonomia na sua vida?

J: primeiro... acho que o que eu busCAva era: eu queria mudar a história da minha família porque eu venho de uma família que ela: vem de classe baixa e:: que nenhum dos meus familiares cursaram a faculdade ainda né?... eu sou o primeiro a entrar em uma faculdade... 
e:: falei... bom... quero: ser o primeiro quero... um dia entrar... porque: ou / outras pessoas da minha família e outros... tipo o meu filho ou o filho da minha irmã... os meus sobrinhos... possam estar dentro de uma faculdade ou estar querendo alguma coisa diferente do que aquela:... do que a vida que meus pais tiveram...

E: legal... é:... você se tornou independente porque quis?

$\mathrm{J}$ : sim... eu me tornei independente porque quis porque eu queria mudar... algo mais além do que minha família já era... tinha para oferecer... apesar de não ter sido uma coisa tão ruim o que minha família tem para oferecer mas assim... eu queria mais... acho que até um pouco ambicioso..." (Anexo, JS23, p. 9, grifos nossos)

Mesmo reconhecendo valor no aporte das "coisas" que seus pais tinham a lhe oferecer, o entrevistado deixa entender que a motivação de buscar uma vida independente veio por vontade própria. Falando em termos narrativos, há, aqui, uma manipulação predominantemente reflexiva. No trecho transcrito, ela se dá tanto pela comunicação do valor modal do querer como pela do dever. A modalidade volitiva é investida pela figura da ambição, ao passo que a deôntica se dá pela figurativização dos benefícios que o ator "JS23" pretende oferecer aos filhos ou sobrinhos futuramente.

No discurso dos entrevistados, as aproximações dos pais são ora tratadas como eufóricas (manipulação transitiva que confere ao sujeito os valores modais necessários à independência), ora como disfóricas (a ação do antidestinador, que se contrapõe aos programas de aquisição de independência e liberdade, que caracterizam a emancipação). Principalmente nos discursos nos quais o ator do destinatário é igual ao do destinador (manipulação reflexiva), a aparição de outro ator, imbuído da função de transmitir capacidade ao sujeito, por vezes é vista com desconfiança, como uma ameaça ao "bom-caminhar" do PN. O próprio JS23 traz outro exemplo disso.

"ao mesmo tempo que / que tem aquele lance dos pais cobrarem dos jovens quererem ser emancipados... depois tem um lado meio paternalístico... porque você tem que estar perto da familia / porque você tem que / ah porque você tem que ajuDAR... porque você tem que dá / estar mais focado familiarmente... então é uma coisa mais tipo... é meio estranho... dizer (...) é que cobra e não cobra... de um lado cobra que você tenha: a emancipação de outro lado... é: você tem que estar mais junto do que o: / da onde você nasceu das suas raízes..." (Anexo, JS23, p. 10, grifos nossos) 
No trecho analisado, constata-se que um ator coletivo ("os pais") desempenha, nesse discurso, dois papéis actanciais, o de destinador e o de antidestinador. 0 primeiro desses dois PNs corresponde a uma manipulação transitiva pelo dever. $\mathrm{O}$ segundo PN também se refere à transmissão de valores deônticos, mas restringe em excesso a ação do sujeito, ao ponto dele não poder se afastar do antidestinador ("a sua família") e ganhar a distância necessária para seguir o próprio percurso. Nesse sentido, do ponto de vista do indivíduo JS23, pode-se afirmar que a ação familiar, apesar de partir de "boas intenções", adquire um caráter prejudicial. Segundo a terminologia tensiva, o percurso transmitido por esse primeiro fazer-fazer pode ser considerado emissivo, pois remete ao que se denomina a parada da parada (Lopes e Tatit, 2008, p. 86). O segundo PN seria pautado pelo princípio remissivo ${ }^{22}$, ao representar a perpetuação da dependência dos filhos, a disjunção entre sujeito e objeto narrativos, ou, ainda, a continuação da parada.

Além das críticas à ação dos pais (antidestinador), o discurso faz também, mais adiante em seu desenrolar, uma avaliação negativa sobre a ação de outro ator (que investe o mesmo papel actancial). É a "sociedade", que seria responsável, ao ver do narrador, pelo encontro com oportunidades que não representam benefícios reais em termos de emancipação. 0 problema com essa manipulação narrativa reside no fato de que as modalidades transmitidas não oferecem uma competencialização que permite ao sujeito entrar em conjunção com o objeto. Outro trecho da entrevista também faz uso de estruturas de manipulação que levam a um antiprograma.

\footnotetext{
"falta um pouco de oportunidade não só oportunidade de:... falar "ó está aqui o: / o emprego está aqui a vaga... o bolsista ou está aqui o... a vaga na universidade" mas sim a oportunidade de mudar com um incentivo falar tipo: 'pô vai lá você pode fazer mesmo' ou... 'você não está conseguindo?' vamos lá nós dois e:... a gente começa a caminhar e:... depois você segue sozinho" (Anexo, JS23, p. 12)
}

O emprego e a vaga na universidade correspondem a figuras discursivas que, em muitos contextos discursivos, recobririam o que se denomina valores narrativos de poder e saber-fazer. Contudo, nesse extrato de texto, as figuras, ao serem transmitidas ao ator do sujeito, não

\footnotetext{
${ }^{22}$ Noções de fazer missivo extraídas de Zilberberg (2006, pp. 138-139).
} 
significam a conjunção com a competência desejada. Talvez representem uma certa vantagem para ele, mas o que é dado não oferece garantias de que irá durar. Assim, a manipulação mais apreciada pelo destinatário ("JS23") é a do segundo programa mencionado ("acompanhamento efetivo"). A recusa do antiprograma pauta-se em uma disposição narrativa que pode ser verificada em outros discursos. Um exemplo está naqueles textos nas quais um indivíduo não confere grande valor a um benefício assistencialista, pois ele simplesmente "dá o peixe, mas não ensina a pescar".

Do ponto de vista da manipulação reflexiva, tem-se verificado que o interesse do destinatário-sujeito nos discursos do corpus costuma estar na duratividade dos valores transmitidos. Além disso, em um registro mais coloquial, pode-se afirmar que há nos discursos dois tipos de indivíduos, os que são mais decididos e assertivos (mais regidos pela pontualidade) e aqueles mais profundos, por exemplo, os que buscam respostas interiores e exploram questões existenciais (próximos da duratividade).

\subsubsection{Manipulação transitiva}

Com uma ocorrência menos frequente, o destinador "não sincrético" também se faz presente nos textos orais analisados, caracterizando-se pelo uso de atores diferentes para cada papel actancial. No caso dessas narrativas de aquisição de emancipação, ele encontra-se usualmente investido por personagens como "os pais" ou "os amigos" dos entrevistados. Por vezes, encontra-se discursivizado por um ator menos próximo do ator do sujeito, tal como "parceiros de trabalho", "artistas", "mestres de cultura popular" ou "ícones do esporte". De todo modo, em sua maioria, representam pessoas que convivem ou que passam por uma proximidade quanto à espacialização e à temporalização do ator do sujeito. Como relata AV24, "a gente vai aprendendo muito com cada pessoa que vai passando na nossa vida assim né..." (Anexo, AV24, p. 2).

No corpus, o investimento discursivo do destinador transitivo normalmente ocorre pelo ator "pais". Nos relatos estudados, esse actante não se encontra investido por um ator que orienta os jovens de maneira profissional e nem oficial (conselheiros, orientadores ou psicólogos - pessoas dedicadas especificamente a essa finalidade). A comunicação dos valores costuma dar-se de uma maneira relativamente involuntária, por vezes até acidental, como no caso dos 
"artistas", que acabam influenciando os jovens sem necessariamente estar produzindo suas obras com esse objetivo em mente.

A manipulação transitiva que é encontrada em um trecho de entrevista de AV24 é particular, pois o destinador, nesse caso, está investido por um ator coletivo. Dentre os personagens que compõem a sua actorialização estão o grafiteiro, o escritor da comunidade que publica seus livros de maneira independente, os mestres de cultura popular de seu centro comunitário, sua mãe e todas as outras pessoas que passaram por sua vida e que marcaram sua experiência em algum sentido (Anexo, AV24, p. 3). Pode-se considerar que há, aqui, um destinador investido por um ator coletivo, multirreferencial, que confere ao destinatário a motivação de "buscar o próprio caminho" de modo processual, cena a cena. Vale lembrar que a concepção de independência trazida por este entrevistado é durativa, além de ser vista como um fenômeno em curso e não terminado. $\mathrm{O}$ actante destinador constrói-se figurativamente por atores que se apresentam a cada pequeno encontro que é narrado. Desse modo, o processo de emancipação descrito pode ser considerado durativo, descontínuo e iterativo, do ponto de vista da aspectualização (Barros, 2002, p. 91).

Pela análise do corpus, verifica-se que o destinador da manipulação transitiva é também investido, muitas vezes, por um ator que vem de um nível social similar ao ator do destinatário. Assim, essa relação se dá, por exemplo, entre jovens que frequentam a mesma escola ou entre amigos de mesma idade ou que frequentam um só lugar. É por causa da recorrência dessa proximidade que é possível afirmar que há uma repetição considerável de cenas nas quais jovens investem o papel de destinador-manipulador, tendo a outros jovens como ator do destinatário. Tal relação é melhor explorada no tópico analítico seguinte ("Manipulação a partir da emancipação").

Tratando ainda da proximidade que há na distribuição actorial da manipulação transitiva, encontram-se particularidades nos casos nos quais ocorre investimento com o ator "pais". No corpus, a figura da mãe ocorre com mais frequência do que a do pai. Se, por um lado, essa actorialização não remete a uma diferença de nível do ponto de vista social, há distinção do ponto de vista da hierarquia familiar. Curiosamente, os entrevistados que, em seus depoimentos, demonstraram ter os pais como referências-chave para suas emancipações tendem a considerar a passagem mais como um processo durativo e em curso do que aqueles que não consideram essa influência tão importante. Isso não significa, contudo, que sejam menos emancipados do que os que declaram não tomar os progenitores como modelo. $\mathrm{A}$ particularidade desse fato parece remeter à duratividade da relação entre pais e filhos, que, 
segundo essa hipótese, corresponderia, em termos semióticos, à aplicação do traço aspectual sobre os valores do sujeito, no nível narrativo. Além disso, ao investir o destinador, o ator "pais" parece, de certo modo, imputar uma maior generalidade ao programa narrativo, conferindo mais importância às suas ações, fazendo-o transitar de um PN de uso a uma amplitude maior, típica de um PN de base.

Quando investido discursivamente por indivíduos da pequena família ("pai", "mãe" e "filho[a]"), o ator do destinador transitivo, independentemente do grau de proximidade quanto ao ator do sujeito (mais próxima, mais distante), representa, normalmente, uma referência importante na transição implicada pela emancipação. A manipulação realizada pelo actante que está investido por esse tipo de ator raramente é tomada como átona ou desimportante. Essa tendência não se constata apenas nas entrevistas dos jovens, o impacto das referências familiares na constituição dos sujeitos é um dos temas do primeiro capítulo desta dissertação, que trata a épica de Sundjata, além de outras tantas referências que já verificaram e estudam essa relação até os dias de hoje, no âmbito de outros campos da ciência.

Paralelamente, quando o destinador transitivo encontra-se investido por um ator que não é familiar ao ator do destinatário ou que não habita em nenhum âmbito o seu universo espacial ou temporal, há certa tendência de que o programa narrativo dessa manipulação não represente uma aquisição de valores significativos para o percurso global do sujeito. Uma convivência mínima (em espacialização ou em temporalização) é essencial para garantir a confiança e a eficácia da manipulação narrativa de um PN que pretende realizar funções amplas, de base, tais como a emancipação, segundo concebida aqui.

A manipulação transitiva admite mais o investimento de atores coletivos como destinadores do que a reflexiva. Nesse último caso, pode haver destinador e destinatário investidos por coletividades. No que tange à transitividade, quando o fazer-fazer é recoberto por mais de um ator, no corpus, isso costuma remeter a uma manipulação que acontece em diferentes cenas discursivas. Além disso, no âmbito das entrevistas, os PNs nos quais há investimento coletivo do destinador transitivo tendem a representar percursos de base, estruturais. SM28 e AV24, em suas entrevistas, trazem esse tipo de construção de sentido. A primeira relata uma passagem que remete, narrativamente, a uma manipulação transitiva (embora possa ser considerada igualmente reflexiva, em alguns aspectos) e está investida por um ator coletivo ("sua mãe" e "duas professoras"). De certa forma, cada uma das representações figurativas (educadoras e mãe) que investem o actante destinador ocupam uma "parcela" da função que representam, transferindo a SM28 a motivação e as condições para que 
possa se emancipar. Isso pode ser visto mais claramente a partir da leitura do trecho transcrito abaixo.

“E: existe alguma pessoa que te inspirou... a querer viver a sua própria vida?

S: ah eu acho que eu não consigo pensar ninguém diferente da minha mãe... ((risos))... na infância é a minha MÃE... e.... na faculdade... tá vamos voltar na escola tem uma professORA... que:... que:... me ajudou um pouco(...) na faculdade... tenho... tive uma professora que: que hoje é minha amiga... que me inspirou / que me inspira muito até hoje... nesse sentido de:... da liberdade conquistada sabe?... de es / de estuDAR MAIS... de trabalhar... de ir atrás... isso foi legal... me inspirou bastante... a da escola é professora lara e a da faculdade é a professora Juliana... mulheres ((risos))... três mulheres..." (Anexo, SM28, p. 19, grifos nossos)

A aspectualização ajuda a compreender como a manipulação narrativa que se encontra nesse extrato de texto ocorre. Há, na passagem, um destinador investido por um ator coletivo e a discursivização da manipulação acontece em três cenas diferentes. $O$ investimento do actante leva a uma ampliação na temporalização e na espacialização da emancipação em questão. A etapa da aquisição de valores modais do nível narrativo, na transição observada, é durativa e está localizada em diferentes marcos estabelecidos dentro do tempo do narrado, no plano discursivo. Além disso, é descontínua e marcada pelo aspecto iterativo (Barros, 2002, p. 91), tal como a manipulação de AV24, descrita acima. Os três marcos de passado (todos em relação de anterioridade quanto ao tempo da narração), cada qual com um ator, um espaço e um tempo diferentes, compõem a manipulação narrativa. Desse modo, o processo de aquisição de independência adquire um sentido mais amplo, uma vez que ocorre ao longo de diferentes cenas discursivas.

Ao reforçar o traço feminino das três personagens que investem o ator do destinador, o discurso faz uma valoração positiva desse traço, em um procedimento de afirmação de gênero. Além disso, é interessante constatar que, mesmo com a manipulação narrativa sendo desdobrada em três cenas discursivas, o sujeito, ainda assim, parece atribuir a si próprio uma parcela da motivação de ser independente, de modo reflexivo. 


\subsubsection{Manipulação a partir da emancipação}

Feitas as observações a respeito da manipulação que faz o sujeito se emancipar, chega o momento de tratar daquela que, além de fazer-fazer, deriva-se da aquisição de independência e liberdade já ocorrida. É uma manifestação narrativa que acontece com relativa frequência em alguns dos depoimentos do corpus, em especial nas entrevistas de AV24 e JS23. Ambos os entrevistados trabalham com ofícios que, de certo modo, aproximam-se do que aqui se denomina manipulação "finalizada-instauradora". Nela, um ator que inicialmente ocupou o papel de destinatário-manipulado (e que se encontra também sincretizado com o sujeito do fazer, após a realização), é avaliado positivamente por um destinador-julgador. A partir desse julgamento, ele mune-se de uma "carga moral" que faz com que desempenhe a função de destinador-manipulador a outro PN. O destinatário desse novo programa, por sua vez, "inspirase" no exemplo observado e obtém conjunção com os valores necessários para suas ações. A inspiração pode ser considerada um fazer avaliativo (Zilberberg, 2006, p. 153).

O percurso da sanção, segundo Greimas e Courtés (2012, pp. 426-427) pode ser de ordem pragmática (um juízo sobre o fazer, com base em um sistema axiológico dado) ou cognitiva (um juízo sobre o ser, com base nas categorias veridictórias e epistêmicas). As manipulações aqui denominadas "finalizadas-instauradoras" utilizam ambos modos de efetivação durante essa etapa.

Muito embora pressuponha uma realização anterior, este tipo de fazer-fazer concatenado com a sanção igualmente pode exercer influência sobre a primeira, caso ela ainda esteja em curso no momento no qual a nova manipulação começa a ocorrer. Tal concomitância faz com que os sujeitos do PN original motivem-se mais, por meio do "reforço positivo" advindo da constatação de que os seus atos estão gerando desdobramentos desejáveis. Em termos correntes, pode-se dizer que os indivíduos que estão se tornando independentes, segundo a influência constatada, motivam-se mais a seguir percorrendo seus caminhos pela boa repercussão de seus atos. Como um exemplo desse tipo de enunciado narrativo, pode-se mencionar o relato abaixo.

Trabalhando com formação de jovens em situação de risco, JS23 procura transmitir um pouco da experiência que acumulou como educador a seus alunos e termina por se tornar uma referência. Afirma que "o sorriso do jovem falando '(...) também posso conseguir... / também vou mudar minha situação" (Anexo, JS23, p. 10) é mais recompensador para ele do que o salário que recebe para fazer o trabalho. Nesse sentido, em termos semióticos, tem-se um ator dado que, após ter investido o papel actancial de destinador, recebe uma avaliação positiva do destinador-julgador. Este é sincretizado com o ator que havia investido o papel de destinatário 
do PN de manipulação pressuposto pela ação. A passagem da manipulação realizada pelo destinador ("JS23") à sanção, executada pelo ator "alunos" dá-se por meio da transferência de uma carga fórica entre essas duas etapas da narratividade, processo que se verá detalhado mais adiante na dissertação. Antes de se tornar referência a outros, porém, esse sujeito precisou passar pelo próprio processo de emancipação, por meio de uma manipulação mista (transitiva e reflexiva), segundo verifica-se no discurso.

A ação educativa que é mencionada nesse trecho de entrevista possui uma abordagem que pode ser vista sob dois modos narrativos diferentes. Primeiramente, ela motiva e inspira os jovens que frequentam o curso a buscarem os próprios caminhos (transmitindo o valor de querer-fazer para tanto). Em segundo lugar, transmite a eles as habilidades e conhecimentos necessários para a ação (transmissão de saber-fazer, no caso).

A observação da entrevista de AV24 também traz elementos pertinentes para a análise da manipulação finalizada-instauradora. Sendo ele um ativista que auxiliou a criar um sistema de economia solidária em seu bairro (um banco comunitário de pequenos créditos), tornando possível que alguns jovens e profissionais de sua vizinhança viabilizassem seus próprios negócios, o discurso transita pelo que se denomina, em semiótica narrativa, manipulação narrativa. Suas ações, em um nível factual, tornam possível que as pessoas de seu bairro realizem uma série de coisas que antes não podiam fazer (manipulação por meio da competencialização, fazer-poder-fazer). Em um trecho no qual são abordadas as figuras da exclusão social, da discriminação por classe e do sistema de transportes urbanos, ele conta um pouco do que significa a sua profissão para a comunidade na qual vive.

"e até a gente: pensando nesse sistema aí... sistema que: né? que não inCLUI o sistema que: só: que só exclui né? é um sistema onde você tem que: você vale o que tem né? muito hoje / hoje: hoje aí:... você vale o que tem muitas vezes... você tem que ter um carro / você tem que ter uma roupa assim / estar se vestindo assim que a gente criou esse sistema nosso aqui de:... de empregabilidade aonde a gente recebe as pessoas a partir do que elas são não do que elas / não do que elas tem respeitando cada uma e:... e:.... e viabilizando::: que elas possam viver daquilo que elas estão fazendo... que é arte cultura... o... trabalhar no social tá ligado?... é:: trabalhar na sua comunidade... sabe? isso é uma vitória você poder trabalhar na sua comunidade coisa que: né?::... a ideia do sistema vigente é você pegar um busão aqui e trampar lá do outro lado... né?" (Anexo, AV24, p. 3, grifos nossos) 
Nesse extrato de texto, o ponto de vista da discursividade acrescenta elementos à análise do nível narrativo. Primeiramente, vê-se a distinção de duas espacialidades distintas, uma mais ligada ao narrado e outra mais vinculada à narração. A primeira, enunciva, é considerada disfórica pelo entrevistado. Nela, a descrição textual constrói um espaço no qual as relações humanas são pautadas por valores sobretudo mercantis e onde os indivíduos valem pelo que possuem. O julgamento que é realizado sobre as ações do ator "pessoas dentro do sistema" estaria pautado, nesse cenário, por um sistema de posse (verbo ter), ou, ainda, pela modalidade veridictória do parecer, em detrimento daquilo que o narrador considera ser a essência das coisas. Na segunda espacialidade, estão os valores considerados eufóricos, que se baseiam em ideais "humanísticos", por assim dizer. Em seu âmbito, as pessoas seriam julgadas por aquilo que o narrador considera ser as suas naturezas, estando as qualidades físicas ou ligadas somente à aparência relegadas a segundo plano.

Ao passo que vê disforicamente o tipo de relacionamento associado à primeira espacialidade, AV24 afirma o valor da ação que ele e seus colegas realizam dentro da comunidade, e reforça a disposição de seguir exercendo esse ofício. Há aqui um único ator sincretizando os papeis de destinador, destinatário (motivando a si próprio a partir do êxito da manipulação anterior, ao efetivar os empréstimos monetários) e sujeito operador da ação (realizando outras mediações bancárias a partir daí). É por meio de construções narrativas como essa que se pode associar a manipulação finalizada-instauradora a eficientes mecanismos de transformação social e emancipação.

Tratando agora do que tange aos valores transmitidos ao actante sujeito no discurso dos dois entrevistados, há uma variedade modal em cada discurso. AV24, com suas ações comunitárias, transmite aos clientes a possibilidade de fazer trabalhos que antes não podiam, por falta de recursos. Segundo critérios do nível narrativo, há aí uma manipulação pelo poder. Em contraste, JS23 usa uma forma diferente de transmissão de competência. O destinador transmite o valor do saber-fazer, trazendo recursos cognitivos aos seus destinatários. O primeiro valor modal (poder-fazer) parece envolver uma comunicação mais pontual entre actantes, ao passo que o segundo (saber-fazer) exige um envolvimento temporal mais durativo para que o destinatário possa receber o valor necessário à realização. 


\subsubsection{Síntese da manipulação}

A análise do texto das entrevistas revela o caráter complexo do fenômeno do fazer-fazer no âmbito da emancipação. Isso se dá graças ao fato de que existem diferenças no modo de comunicação de valores modais (transitivo ou reflexivo), variações decorrentes da posição e da sequência do percurso narrativo (instauradora, finalizada-instauradora), assim como dos tipos de aspectualidade que envolvem cada ato.

De modo geral, vê-se que o ator do sujeito que passou por manipulação sincrética possui uma propensão a fazer avaliações eufóricas e assertivas sobre si. Nos momentos nos quais há atores distintos na manipulação, a sanção costuma ser mais rica de elementos discursivos, verificando-se uma maior complexidade de figuras e temas. Nesses últimos casos, por outro lado, não necessariamente os narradores deixam de se mostrar confiantes quanto a suas capacidades pessoais.

A actorialização do destinador transitivo dá-se normalmente por parentesco, amizade ou simplesmente admiração. De modo geral, trata-se de um ator próximo aos jovens, que compartilha suas cotidianidades de algum modo. Quanto à espacialização dessa manipulação, há variação de caso a caso, com a possibilidade de existirem processos mais complexos (que se constituem a partir de várias cenas discursivas, em vários cenários), assim como outros mais simples (nos quais há uma unidade espacial apenas).

Como mencionado acima, a amplitude da significação de cada um dos programas narrativos atribuídos às passagens de manipulação no corpus varia. Há aqueles PNs que são mais significativos, mais caudais com relação ao fluxo da narratividade, e aqueles menos importantes para o desenvolvimento das histórias. No que tange aos programas de base, viu-se que grande parte deles encontra-se relacionada à manipulação reflexiva, ao passo que os PNs de uso são mais associados à comunicação transitiva de valores modais.

\subsection{Virtualização e atualização nas entrevistas}

Tendo sido analisadas as diferentes formas de manipulação narrativa que se encontram por trás dos relatos dos jovens entrevistados, e à luz das reflexões feitas sobre a fidúcia de Sundjata, chega o momento de dedicar mais atenção às passagens que trazem virtualização e 
atualização ao sujeito no corpus. Essa investigação se dá com base na divisão dessas duas etapas do percurso narrativo, a partir de suas articulações com as modalidades do ser e do fazer.

Primeiramente, é necessário que se reconheça a divisão entre as duas grandes categorias de enunciado que a semiótica de linha greimasiana lega ao estudo das narrativas, a saber, o enunciado de fazer e o enunciado de estado. Na primeira, há mais movimento, os sujeitos agem e as transformações são sua decorrência. Greimas (2014, pp. 106-107) classifica as relações dessa categoria como intencionais. O autor ainda diz que "as modalizações do fazer são alterações do estatuto do sujeito do fazer e que as modalidades que o afetam constituem sua competência modal" (p. 107, grifo do autor). A segunda categoria, por sua vez, serve para nomear os momentos e as junções entre sujeito e objeto, agrupados sob a denominação de relações existenciais. Essas são consideradas a partir do estatuto juntivo do objeto. As modalidades que afetam os valores nele investidos constituem a existência modal do sujeito de estado. Nesse segundo momento, o estatuto dos objetos de valor é observado com maior atenção, lembrando que isso significa uma análise dos valores citados, assim como da existência modal dos sujeitos.

\subsubsection{Modalizações do ser}

Em "Modalizações do ser" a atenção é dedicada ao enunciado de estado que liga o sujeito ao objeto de valor. Em um primeiro momento, observam-se as categorias do querer e do dever. Depois de vistas as manifestações "puras" de cada modalidade, as confrontações tomam a cena da análise, em busca da aplicação de conceitos já propostos por Greimas (2014), tais como a homologação dos sistemas modais. Nesse momento, a problemática da atualização entra em pauta, em sua confrontação com a virtualização.

No capítulo "Discursividade da emancipação nas entrevistas" viu-se, entre outras coisas, que os indivíduos que concederam entrevistas para o presente estudo não deixam de lado as perspectivas de engajamento e militância, articulando a ação política com base em estruturas linguísticas coletivas ou singularizadas. O olhar sobre a modalidade narrativa do querer, utilizado no presente tópico, agrega tópicos de análise às reflexões realizadas quanto a esse ponto. 


\subsubsection{Modalidade volitiva}

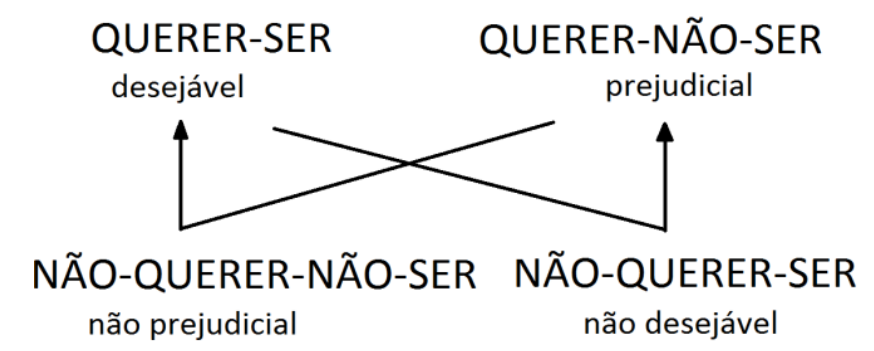

Figura 6 - Quadrado volitivo, formulação feita por Greimas (2014, p. 109)

A articulação das modalidades do querer-ser, como ilustra o quadro acima, traz quatro diferentes posicionamentos, de acordo com a aplicação das possibilidades de suas articulações contrárias e contraditórias. Mesmo que a terminologia sugerida para se designar cada uma das modalidades ("desejável", "não prejudicial", "prejudicial" e "não desejável”) seja provisóriaa", aqui se considera proveitoso mantê-las, para uma melhor operacionalidade das reflexões.

O querer-ser, a princípio, remete a uma noção em grande parte autoexplicativa, por seu significado em língua natural. Sua natureza pode ser compreendida como disponibilidade por parte do sujeito de ocupar um dado valor de ser. A partir dessa reflexão, as outras possibilidades são deduzíveis, querer-não-ser como disponibilidade para não-ser; não-querer-ser como indisponibilidade a ser e não-querer-não-ser como indisponibilidade a não-ser. Ainda na data de publicação do volume I do "Sémiotique. Dictionnaire raisonné de la théorie du langage" (1979), Greimas e Courtés afirmavam que a lógica volitiva não se encontrava pronta para fornecer terminologia às denominações semióticas. Com o lançamento de Du Sens II, em 1983, é que aparecem os termos explicativos das categorias do querer-ser.

Como bem lembra Greimas, os valores modais (também objetos de valor dos enunciados de estado) podem estar ou não em conjunção com o sujeito narrativo (2014, p. 111). Este, por sua vez (como visto no tópico "3.1 Manipulação") pode estar investido por um ator em sincretismo ou não com o ator que recobre o sujeito do fazer. Nesse sentido, o autor lembra que o sujeito de estado possui uma existência modal que pode ser perturbada a qualquer momento, submetida às transformações realizadas pelo sujeito de fazer.

Para dar início à análise no que tange à distribuição figurativa e temática do corpus em sua relação com as modalidades volitivas, um quadro esquemático distribui as ocorrências

\footnotetext{
${ }^{23}$ Greimas (2014, p. 109) admite, quanto às formulações em francês, que os termos que se encontram em letras minúsculas em cada uma das posições do quadrado podem vir a ter melhores formulações, encarregando dita tarefa ao que chama de um "comitê terminológico".
} 
discursivas segundo cada articulação modal do querer. Lendo-se o quadro a seguir, as figuras devem ser interpretadas como "representantes discursivas" dos valores, em relação com o sujeito de estado (não necessariamente estando conjuntas ou disjuntas deles). Cada caso encontra, em sua realização textual, disposições discursivas e narrativas próprias e deve ser analisado a partir das particularidades que trazem os textos dos quais se depreende.

\begin{tabular}{|c|c|c|}
\hline Modalidade & Temas & Figuras \\
\hline \multirow[t]{8}{*}{$\begin{array}{l}\text { Querer-ser } \\
\text { (Desejável) }\end{array}$} & Relacionamentos & $\begin{array}{l}\text { Ser mãe } \\
\text { Estar entre amigos } \\
\text { Estar junto das gerações mais velhas }\end{array}$ \\
\hline & Diversidade & Ter variedade na vida \\
\hline & Identidade & $\begin{array}{l}\text { Ser negro / negra (Identidade racial / afirmação / Cabelos } \\
\text { afro) } \\
\text { Ser musicista } \\
\text { Ser ativista social } \\
\text { Ser adulto } \\
\text { Ser quem se é na essência } \\
\text { Ser o que quiser } \\
\text { Ter cabelos afro } \\
\text { Ser mulher }\end{array}$ \\
\hline & Beleza & Ter cabelos afro \\
\hline & Independência & $\begin{array}{l}\text { Ser independente financeiramente } \\
\text { Não depender de ninguém }\end{array}$ \\
\hline & Organização & Ser organizado / arrumado \\
\hline & Maturidade & Ser adulto \\
\hline & Liberdade & Ser protagonista do próprio destino \\
\hline \multirow[t]{4}{*}{$\begin{array}{l}\text { Não-querer-ser } \\
\text { (Não desejável) }\end{array}$} & $\begin{array}{l}\text { Solidão } \\
\text { Ensimesmamento }\end{array}$ & $\begin{array}{l}\text { Ter uma vida de rotina } \\
\text { Depressão }\end{array}$ \\
\hline & Rejeição & Bullying escolar \\
\hline & $\begin{array}{l}\text { Descompromisso } \\
\text { Dúvida }\end{array}$ & $\begin{array}{l}\text { Ser independente } \\
\text { Ser adulto } \\
\text { Ser chefe de família }\end{array}$ \\
\hline & Aparências & $\begin{array}{l}\text { Ter cabelo cortado } \\
\text { Vergonha do próprio corpo }\end{array}$ \\
\hline $\begin{array}{l}\text { Querer-não-ser } \\
\text { (Prejudicial) }\end{array}$ & Transformação & $\begin{array}{l}\text { Ter cabelos alisados } \\
\text { Ser adulto }\end{array}$ \\
\hline
\end{tabular}




\begin{tabular}{|l|l|l|}
\hline & Ocultamento & Discriminação “introjetada” \\
\hline & Tristeza & Insatisfação com o próprio corpo \\
$\begin{array}{l}\text { são-querer-não- } \\
\text { (Não-prejudicial) }\end{array}$ & Liberdade & Voltar a enxergar a própria beleza \\
\hline & Mudança & \\
\hline & Relacionamentos & Abandono do alisamento de cabelos \\
\hline
\end{tabular}

Quadro 1 - Figuras e temas, distribuídos nas modalidades volitivas.

Em um primeiro momento, vê-se que a modalidade do querer-ser tem mais variedade figurativa nos textos. As demais modalidades (querer-não-ser, não-querer-ser e não-querernão-ser) são menos significativas em termos de número de ocorrências. Por outro lado, talvez devido à variação que ocorre durante a etapa de sistematização das figuras, a quantidade não significa objetivamente um foco maior por parte dos discursos nessa modalidade narrativa. Assim, não se deve julgar que as últimas categorias acima mencionadas tenham sido desimportantes para os textos.

A passagem transcrita abaixo, trazida por SM28, propõe um movimento que se inicia pela negação do querer-ser adulto, culminando em uma valoração desejável da mesma figura.

“... ANtes... quando eu era... mais nova... eu via a vida adulta de um jeito mais chato assim mais:... mais... organizado talvez mais... cheio de responsabilidades... então... uma coisa mais linear mais rotineira... ser adulto para mim tem relação com com rotina... com... com o igual ((risos))... \{E: uhum \{S: mas:... agora que eu estou ch / ... que que estou chegando... ESTOU numa fase mais... adulta e ho / e no... TEMpo que a gente vive hoje... que as possibilidades são / são maiores...né?... que o o LEque... de escolhas e:... tem (que estar) mais aBERto... eu vejo a vida adulta... mais como uma consolidação talvez da juventude... dos processos... que eram... mais:... mais no SOnho... ou mais no: / na imaginação eu vejo a vida adulta mais... nesse processo de solidificar ISso... (não)... SOlidificar mas talvez realizAR: algumas coisas..." (Anexo, SM28, p. 16, grifos nossos)

Respondendo ao questionamento sobre o que significa ser adulto, a entrevistada constrói seu discurso por meio de um percurso que parte do valor narrativo não-querer-ser. Essa categoria modal se encontra expressa no discurso pelo termo "chato" e pelas expressões "mais linear", "mais organizado", "mais rotineira" e "mais cheio de responsabilidades". A disforia, atribuída à figura do adulto, dá-se por mecanismos tensivos de acréscimo de tonicidade 
(expressos, sobretudo, pela palavra "mais"), que criam uma noção de excesso (de comprometimentos e repetições). Eles recaem sobre a figura da adultez, que acaba por ser considerada uma parte ruim da existência das pessoas.

Depois do amadurecimento do ator, porém, acontece uma mudança de perspectiva. É nesse momento que, no nível narrativo, o sujeito entra em conjunção com a modalidade do nãoquerer-não-ser (não prejudicial). A figura da adultez é vista, então, com um traço não disfórico. Essa "mudança de tom" quanto ao modo de se enxergar a etapa madura ocorre porque o fechamento de possibilidades de vida que não permitiria ao sujeito estar confortável quanto ao futuro não se efetiva. Em termos mais correntes, a passagem à vida adulta perde a conotação negativa e acaba ganhando o status de uma "juventude melhorada", no sentido de que, sem perder o privilégio da abertura de oportunidades, os planos que antes ficavam apenas na dimensão cognitiva ("sonho", "imaginação") agora podem passar à esfera pragmática (que realiza coisas). Ao final do trecho transcrito, SM28 encontra-se feliz com a passagem do tempo e quer ser adulta.

Imanishi (2008, p. 45), relendo trabalhos de outros autores como Zygmunt Bauman, reconhece que a juventude dos dias de hoje tem de lidar com valores de incerteza em âmbitos variados (como o crescente desemprego e a instabilidade na área do trabalho). Levando essas afirmações sociológicas em conta, prevê-se que a entrevistada pode estar sendo, de algum modo, influenciada pela descontinuidade que é vivenciada por muitos indivíduos na sociedade pós-moderna. A falta de uma carreira profissional delimitada, por exemplo, é um fator de incerteza em sua trajetória. A despeito disso, ela pode enxergar, desde a perspectiva individual, alguma solidez no que tange à realização de projetos e de sonhos de adolescência e infância e isso lhe traz satisfação.

\subsubsection{Querer e não-querer-ser}

Posto isso, é interessante a observação mais atenta de um trecho da entrevista de JS23. O jovem traz uma visão pouco comum de um fenômeno que a princípio seria considerado positivo, ganhar bolsa de estudos em uma escola particular.

“o jovens... de periferia... não sai do / da periferia para ir para o centro para... para fazer algum curso: por medo de:... pegar bolsa em alguma / em alguma escola particular... para 
estudar... porque ele sabe como que é né? tipo... se você está dentro de uma escola particular... você é o único bolsista você vai... o pessoal vai ficar te chamando "ah... você é o bolsista... você não s / vocên / você não tem dinheiro..." (Anexo, JS23, p. 11, grifos nossos)

Vê-se que JS23 vê com descaso o benefício, muito embora ele represente uma oportunidade de formação que normalmente seria desejável para muitas pessoas. Examinando a passagem do ponto de vista modal, a figura da bolsa investe a transição de um não-poderfazer (impotência) a um poder-fazer (liberdade). Embora esteja diante de uma liberdade, 0 sujeito considera não desejável o valor que se apresenta. Para ele, trata-se da manipulação de um antiprograma. A conotação que é dada ao oferecimento de bolsas remete a um fazer normativo (Zilberberg, 2006, pp. 152-153), ou a uma sanção narrativa. A figura é, no trecho analisado, tomada como uma relação que se estabelece entre dois actantes, um destinadorjulgador ("o pessoal da escola") e um destinatário-julgado ("o aluno bolsista"), representando o mecanismo pelo qual o objeto adquire valor indesejável para o sujeito.

Segundo a visão do entrevistado, as escolas particulares paulistanas, constituídas majoritariamente por alunos brancos e vindos de famílias com uma faixa de renda média ou média-alta, tornam-se lugares nos quais estudantes negros ou com baixo poder aquisitivo estão sujeitos a ser mal vistos, por conta da discriminação. Quando a mesma relação é aplicada a instituições públicas, pode-se supor que talvez os brancos ou com maior renda é que seriam considerados exceções. A normatividade do ambiente educacional é uma questão que, além de ser pertinente ao nível do referente (das considerações sociológicas), importa ao estudo da significação, uma vez que a linguagem é corresponsável pela criação das ideias de mundo dos indivíduos.

\subsubsection{Narratividade e preconceito}

Barreto (2008, pp. 64 - 66), em livro que foi resultado da publicação de sua pesquisa de doutorado, "Múltiplas vozes: racismo e antirracismo na perspectiva dos universitários de São Paulo", reúne alguns depoimentos de jovens da capital paulista falando sobre esses dois temas. Dentre as reflexões que constam no trabalho, é abordada a questão da presença de alunos negros nas escolas e universidades. Um dos relatos destaca-se por expor o assunto tratado no 
tópico anterior, as bolsas em instituições de ensino particulares, proferido pelo estudante Luís, do Instituto de Biologia da USP.

O rapaz conta que, em seu tempo de escola, havia apenas um aluno negro na instituição, e que tal traço o mantinha sempre em destaque. Menciona que o desequilíbrio de representatividade racial não era um tema tratado pelos professores. Quando abordado, em suas palavras, era "tratado da forma mais 'vaselina' (...) Politicamente correta, não pode discriminar, não pode isso, não pode aquilo" (p. 64, relato do entrevistado) e, assim a abordagem tornava-se o que ele chama "uma conversa super superficial" (p. 64). A falta de naturalidade no tratamento constatada por Luís, reflexo, talvez, de uma falta de preparo por parte dos profissionais da instituição em questão, é, possivelmente, uma das razões que por vezes tornam pouco "apetecíveis" as oportunidades de ocupação das vagas concedidas nas escolas particulares, às quais JS23 faz menção na entrevista do presente corpus.

Uma das modalidades narrativas que descreve a concessão de vagas é não-dever-nãoser (valor realizável, segundo Barros, 2002, p. 59). No caso, ele refere-se à ação do destinador que, ao transferi-lo ao destinatário, nega uma impossibilidade. Isso pode ser compreendido, em um nível mais factual, como um contraponto diante da inviabilidade de que alunos com poucos recursos financeiros estudem em organizações particulares. Apesar das "boas intenções" do oferecimento de vagas, o estigma que recai sobre o jovem que é incluído no âmbito interno dessas instituições faz com que a proposta the soe indesejável. O preconceito racial vigente nas escolas (tema poucas vezes abordado com efetividade no cotidiano de tais locais) incorre na reprodução dos padrões normativos que conferem aos bolsistas um lugar de não pertencimento. Os alunos brancos da escola, ao reproduzirem a discriminação, estariam ocupando, em termos narrativos, o papel de antidestinador manipulador, em um programa no qual o destinatário estaria investido pelo ator "estudante bolsista".

Indo além desses dois casos, outros resultados obtidos pelo estudo de Barreto (p. 67), apontam que os jovens atribuem a influência do fator econômico na discriminação e na exclusão dos negros no acesso a escolas particulares e de melhor qualidade e, posteriormente, a cursos de maior prestígio na USP. Corroborando essa mesma ideia, e voltando ao depoimento de JS23, vê-se que ele temeria sentir-se excluído caso ingressasse na escola particular como bolsista também por não dispor do padrão de renda dos colegas.

"você está lá no: no âmbito:... escolar e: de repente... seus amigos começam a discutir "pô... fui para Paris ontem à noite fui para: para Milão não sei que lá..." e você simplesmente 
ficou em Parelheiros ou você ficou no Grajaú ou você ficou em x lugar e:... você fala (...) tinha que ouvir isso'..." (Anexo, JS23, p. 11, grifos nossos)

Quando se confrontam a liberdade do sujeito "outros alunos" e o poder-fazer do sujeito "JS23", a contraditoriedade modal que se dá a partir da comparação entre os dois percursos gera um desconforto. O programa narrativo do segundo parece diminuído diante do alcance "mais potente" do primeiro PN. Ao mesmo tempo, isso faz com que o sujeito investido pelo bolsista entre em conjunção com o valor de querer-não-ser, negando, no nível discursivo, o interesse de estudar na instituição. No plano factual, as dificuldades decorrentes da ocupação desse lugar de alteridade dentro de uma instituição são obstáculos à efetividade de certos tipos de ação social no âmbito da inclusão.

A concessão de bolsas de estudo pensada apenas como acesso é insuficiente para garantir a permanência dos beneficiários nas instituições de ensino. Existe uma indisposição por parte de certos indivíduos de frequentar escolas privadas ou as universidades, que é decorrente das práticas de discriminação infelizmente ainda vigentes em alguns dos ambientes de ensino do país, assim como existem problemas decorrentes de outros tipos de carência que os jovens por vezes sofrem ${ }^{24}$. A falta de vontade de ocupar o lugar de não concomitância com um "padrão" étnico (ou econômico) no perfil de certas escolas ou universidades, pode ter sido o que levou Barreto a verificar que o tema do "temor da mistura" foi um dos assuntos mais tratados por seus entrevistados (p. 160). Uma educação para a valorização do diferente no âmbito social é uma conquista ainda a ser transposta pela educação brasileira.

O preconceito foi um tema bastante abordado pelas entrevistas concedidas ao presente estudo. Com o intuito de observar o modo como as práticas de racismo constroem-se em cada um dos níveis de significação dos textos coletados, parte das perguntas feitas aos jovens durante a etapa de coleta do corpus foi dirigida a esse tema e, a partir delas, foi possível extrair uma quantidade considerável de relatos. Essa relativa "facilidade" de conseguir falas sobre o racismo também se fez notar em Barreto, em ocasião na qual aponta igualmente a visibilidade do fenômeno no contexto atual (p. 159).

\footnotetext{
24 Barreto (p. 159) constata que a existência do racismo no Brasil é uma unanimidade entre seus entrevistados e uma tendência verificável no discurso de diversos autores que tratam o tema.
} 


\subsubsection{Imagens de si}

As modalidades virtuais querer e dever-ser (e suas derivações categoriais) fornecem um instrumental funcional para a análise da temática do preconceito e da discriminação racial. Quando se analisa, por exemplo, o percurso que vai da construção de uma desvalorização de si (não-querer-ser) a uma revalorização do próprio corpo e de suas características (querer-ser), tal como no discurso de SM28 (transcrito abaixo), vê-se que praticamente todas as posições do quadrado semiótico do querer-ser são utilizadas pelo discurso da narradora.

“eu... gosTAva... do / do meu cabelo (...) mas:... eu entendia que eu não era aceita: no grupo ou não era aceita: no contexto por conta do meu cabelo aí eu passei a: aliSAR o cabelo... e esse processo foi violento para mim primeiro porque eu não gostava do jeito que ficava o meu cabelo... e segundo... porque:... era um / uma:... normatização né?... eu fazia aquilo para me encaixar... e ãn / a prime / eu lembro: / é muito CLAro assim a primeira vez que eu fiz ((risos)) relaxamento que o cabelo balançava eu saía na rua com aquele cabelo balançando e balançava para lá e para cá e pô eu fiquei uma semana assim superempolga:da... aí de repente quando eu: / quando eu olhei no espelho e tipo: 'que / quem é essa pessoa aí né?' e aí foi vã / muitos anos até eu / eu parar... sei lá acho... que com QUINze... quaTORze quinze Anos (...)" (Anexo, SM28, p. 17, grifos nossos)

Inicialmente, regido por uma manipulação sincrética, o sujeito via como desejável a conjunção com o objeto ("o próprio cabelo", tal como ele era naturalmente). Mas o aparecimento de um outro destinador, transitivo e actorializado pelo "grupo" ou pelo "contexto social" (no qual o ator do sujeito também se insere), faz com que deixe de querer estar em conjunção com o objeto. O contrato fiduciário entre o sujeito e o último destinador goza de relativo vigor, de modo que a transferência de valores acontece com sucesso. Nesse momento, o sujeito partilha do sistema de valores do destinador, investido discursivamente pelo ator "grupo" e o objeto de valor "cabelo" é considerado indesejável. Em outras palavras, é um traço que deve ser renunciado para que a protagonista possa fazer parte do grupo ou contexto com o qual se identificava.

Após a conjunção com os valores desse destinador ("grupo"), o sujeito avalia a sua ação, no episódio do espelho. O que acontece então é uma sanção narrativa, na qual reconhece o que vinha fazendo. Ao tomar consciência das consequências que existiam por trás dos valores 
assumidos, o sujeito "SM28" efetua uma ruptura no contrato fiduciário que havia estabelecido. Os valores do primeiro programa pautavam-se no enquadramento do ator do sujeito em um padrão estético que exigia um constante esforço e que, muitas vezes, mostrava-se inalcançável.

Indo além da manipulação pela modalidade volitiva, descrita acima, há também na manipulação travada entre o destinador transitivo e o destinatário a presença da categoria do dever-ser (alética). Se, em um primeiro momento, a amizade que havia entre o ator discursivo "SM28" e "o grupo de amigas" parecia bem estabelecida (dever-ser), em dada passagem essa relação é questionada (não-dever-ser). Há um descompasso entre a aparência "ideal", estabelecida pelo grupo, e a "real", que era a do ator do sujeito. Em suma, a passagem trata de um episódio de racismo, segundo se depreende a partir do relato. Com o aprofundamento desse impasse e o estabelecimento do não pertencimento do ator "SM28" na coletividade, surge o valor narrativo do dever-não-ser. Vê-se, aqui, um sujeito virtualizado nas modalidades do devernão-ser, não-querer-ser e querer-não-ser. 0 quadro abaixo ilustra esquematicamente a passagem.

\begin{tabular}{|l|l|l|l|l|}
\hline \multirow{2}{*}{ Manipulação } & Destinador & Não-querer-ser & Querer-não-ser & Dever-não-ser \\
\cline { 2 - 4 } & Destinatário & $\begin{array}{l}\text { Não gostar do } \\
\text { próprio cabelo }\end{array}$ & $\begin{array}{l}\text { Desejo de } \\
\text { apagamento dos } \\
\text { Virtualização africanos do } \\
\text { próprio corpo }\end{array}$ & Não pertencimento \\
\hline Nível discursivo & Figuras & & \\
\hline
\end{tabular}

Quadro 2 - Virtualização do programa narrativo de SM28

Durante a etapa de manipulação depreendida no trecho transcrito, o sujeito encontrava-se ainda sob influência do destinador ("grupo"), mas não tinha encontrado a "força interna" necessária para interromper o fluxo desse programa narrativo. Este lhe destinava valores que faziam ver o objeto ("cabelo") como algo não desejável, gerando uma tensão crescente e demandando constantes e abundantes esforços para a transformação de sua natureza, como se pode depreender com a leitura do trecho a seguir.

eu usei química até os vinte e três... quase dez / dez Anos de / de / de uma:... roTina de / de / de ir para o cabeleireiro de esticar do cabelo cair de quebrar daí faz o jeito para... \{E: você fazia:... diariamente? \{S: era o m / mã / não era diariamente né? sei lá eu ia para o salÃO... cada dois meses para / para fazer química ou ahn... era o cabelo cresCER... começar um 
raizinha a crescer e já tinha que alisar né?... (...) então até:... e para EU... toMAR: a atitude de: / de deixar de usar química foi isso eu... estava em um processo de usar química usar química aí de repente eu fui mudar de um produto para ver se ele ficava MEnos artificial... e aí o cabelo caiu... caiu que ficou... muito curto / muito quebrado aí eu falei: "chega"... aí corTEI... o que dava para cortar... e falei: "a partir de agora eu não vou mais fazer isso" ... e aí foi uma descoberta inCRÍvel de descobrir como é que ele / de relemBRAR como é que era o meu caBElo de texTUra de ver ele cresCER de v / de ver... várias descobertas assim e foi / foi be:m... legal..." (Anexo, SM28, p. 17, grifos nossos)

O texto acima ilustra, sobretudo, a passagem do primeiro para o segundo programa narrativo. O valor dever-não-ser, transmitido pela coletividade em questão ("o grupo de amigas") - e também pelo ator "SM28", que aderia a esse sistema de valores, converte-se em não-dever-não-ser. Isso corresponde à possibilidade de realização (poder-ser), do ponto de vista do sujeito, discursivizada pelo "cabelo natural crescendo" e pela "negação da inviabilidade do pertencimento" a alguma identidade, ainda que não mais a que primeiro se havia instalado. A ação, a partir daí, vê-se regida pela manipulação de um novo destinador. SM28 perpassa, com esse trecho de fala, um dos pontos de contato entre modalidades narrativas que Greimas descreve, ao confrontar as categorias do poder e dever-ser, no âmbito da homologação da compatibilidade e conformidade (2014, pp. 94 - 95).

\section{Compatibilidade e conformidade}

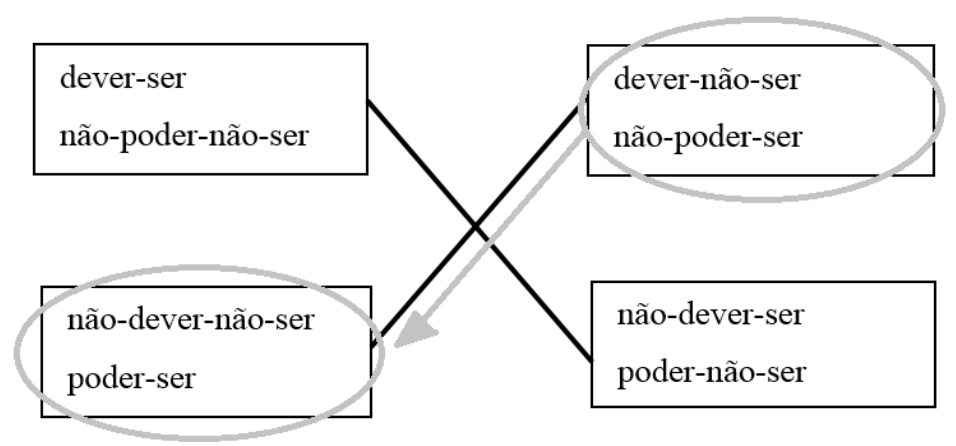

Figura 7-Compatibilidade e conformidade entre poder e dever-ser 
A confrontação do não-dever-não-ser com o poder-ser (ambos os termos designados pelo termo "possibilidade", destacada no quadro), mostra como o sujeito, indo além da influência do primeiro destinador, estabelece outro contrato, desta vez com um destinador reflexivo. Este novo laço é suficientemente forte para assegurar a troca de direção da ação. Há aqui a presença de um actante sincrético, que reúne os papéis de destinador, destinatário e sujeito de estado e ação em um único ator ("SM28"). A impossibilidade de continuação do primeiro programa narrativo, representada pelo episódio da queda de cabelos (que também significa a extenuação do valor do objeto), marca a mudança no sentido da adesão do sujeito.

A ida aos níveis tensivo e aspectual presta-se, nesse momento, para localizar alguns elementos que identificam os detalhes da passagem, auxiliando a compreender a motivação de SM28 em seu caminho de libertação das pressões sociais vindas do grupo de amigas (manipulações aléticas e volitivas propostas pelo antidestinador). Inicialmente, chama a atenção a duratividade descontínua e iterativa no uso dos produtos químicos e a presteza (aceleração) com a qual a narradora lidava com o aparecimento dos fios novos, tal como se vê na frase a seguir: "era o cabelo cresCER... começar um raizinha a crescer e já tinha que alisar né?" (Anexo, SM28, p. 17). O breve intervalo entre o nascer e o alisamento dos fios e a rapidez com a qual utilizam-se os produtos capilares remete a uma aceleração do andamento, no eixo da intensidade.

Para explicar a forma como o efeito de intensificação se constrói, é pertinente a utilização do modelo das quantificações subjetivas, formulado por Zilberberg (2011, pp. 55 58). Essa proposta teórica estabelece como os dois incrementos mínimos da significação tensiva, o mais e o menos, os quais podem, por sua vez, ser articulados nos regimes intransitivo (valendo por si mesmos); transitivo, no qual há mais menos ou menos mais; ou ainda reflexivo, onde há menos menos e mais mais.

Na passagem analisada, verifica-se a ocorrência de um recrudescimento (mais mais), expressa, entre outros elementos, pela "super-empolgação" do ator "SM28" diante da novidade dos cabelos lisos (vide trecho transcrito acima). Quando os efeitos dos exageros da química começam a se fazer visíveis, ele vê o procedimento com desconfiança (menos mais, atenuação). Então, o ator procura uma saída, agindo de modo diferente ("mudança de produto"), mas esse ato agrava o estrago (mais menos, minimização), pois faz com que os fios se quebrem e caiam. Recorrendo a termos do nível narrativo, pode-se dizer que isso acaba com o valor do objeto para o sujeito (somente menos). 0 que resta para o ator discursivo, a partir de então, é suspender o uso dos produtos e cortar o que restava dos cabelos. A partir daí, aos poucos, restabelece-se a 
sua aparência com o crescimento dos fios novos (em terminologia tensiva, esse fenômeno pode ser expressado pelo menos menos, restabelecimento, p. 60).

Voltando às reflexões feitas quanto ao nível narrativo da significação, vê-se que o sujeito está, ao final do trecho transcrito, novamente virtualizado com a modalidade do querer-ser, mas também mais convicto de seu programa por meio do valor de dever-ser, que lhe é transmitido pelo destinador e pelo qual se pauta a partir de então. A conjunção com o valor de não-devernão-ser, mencionada acima, foi uma das configurações que permitiu a constituição dessa identidade afirmativa (querer e dever-ser), uma nova disposição do sujeito diante do PN. No nível discursivo, a figura dos traços étnicos passa da disforia à euforia.

\subsubsection{Conclusões parciais}

A partir das constatações realizadas no tópico 2.1 ("Modalizações do ser"), sintetizamse agora algumas conclusões parciais. Em primeiro lugar, vale apontar que, na distribuição de temas e figuras relacionadas à modalidade volitiva, há mais variedade no que tange ao valor desejável. Viu-se que os entrevistados consideram o ato de se tornar adultos um fenômeno sumamente eufórico, discorrendo mais sobre os aspectos bons do amadurecimento. Muitas das atividades que realizam em suas vidas atuais, como pessoas em processo de emancipação, dispõem dessa mesma vontade e otimismo, ainda que alguns deles não se considerem plenamente independentes.

Ainda sobre a classificação dos elementos discursivos pelas diferentes modalidades do querer-ser, verifica-se, em uma quantidade relativamente pequena, a presença de aspectos não desejáveis da adultez. Há, também, alguma menção aos pontos indesejados do ser jovem. Quanto às figuras relacionadas à categoria prejudicial (querer-não-ser), pode-se dizer que estas estão relacionadas sobretudo a crises de identidade e que remetem, entre outras coisas, a passagens que trazem episódios de discriminação e dificuldades de inserção social por parte dos indivíduos.

A figura do preconceito racial parece perpetuar-se nos textos do corpus pelo que se denomina, nos termos do nível narrativo, a construção de um fazer normativo. No nível discursivo, há aí o estabelecimento de um padrão social, que determina alguns perfis de indivíduos como adequados, ou não, a lugares específicos. Esta constatação foi depreendida a partir da análise do discurso de JS23, quando falava da oferta de bolsas de estudo em escolas de ensino privadas. Além disso, observou-se que o discurso do "politicamente correto", 
articulado narrativamente pela categoria da possibilidade (não-dever-não-ser), pode ser constrangedor em alguns contextos. Isso se dá pela exposição segregativa à qual os indivíduos supostamente beneficiados por vezes se veem submetidos.

As normatividades (manipulação pelo dever) instauradas no discurso valem-se da projeção de valores de necessidade no destinatário. Algumas vezes, essa manipulação se dá a partir da construção de ideais corporais. Os valores relacionados a esse tema são inicialmente considerados desejáveis pelo destinatário, porém, ao mesmo tempo, podem ser considerados "ilusórios", do ponto de vista da veridicção, pois, por vezes, não correspondem à possibilidades reais de transformação corporal por parte do ator discursivo.

A partir da experiência de SM28, constatou-se que a construção de imagens de si a partir de padrões vindos de terceiros pode, por vezes, significar um procedimento demasiado custoso e que não traz os benefícios que promete. Ainda nesse sentido, vê-se que certas vivência do ator estão sujeitas a alterar isso, tal como ocorreu no episódio do espelho, quando, após avaliação minuciosa dos traços que pensava serem necessários a seu bem-estar, a jovem descobriu beleza e satisfação em sua aparência, sem necessidade de grandes intervenções.

A título de conclusão, pode-se afirmar, sobre esse tipo de normatividade, que há, no corpus, uma associação entre o tema naturalidade e a manipulação narrativa reflexiva (euforizada); simultaneamente, existe uma outra correspondência, paralela, que liga o tema da artificialidade à manipulação transitiva (tomada como disfórica).

\subsubsection{Modalizações do fazer}

A proposta deste tópico é analisar o corpus a partir das modalidades virtuais e atuais conjugadas à ação. Refere-se à intencionalidade, vista em seu contraste quanto à existencialidade, segundo a oposição entre as categorias do fazer e do ser, respectivamente (Greimas, 2014, p. 106). Em outras palavras, o foco agora aproxima-se do modo como os sujeitos operam sobre o mundo. O fazer é visto aqui não apenas em sua dimensão realizante, mas como uma base sobre a qual as outras modalidades incidem. Fiorin $(2012$, p. 102) compõe o quadro modal com as categorias assumir, aderir, querer, dever, saber e poder. A utilização deste quadro, que complementa a formulação de Greimas e Courtés (2012), foi inicialmente proposta por Fontanille e Zilberberg (2001, p. 256). Essa proposta é vista como mais completa do que o modelo greimasiano por incluir, no percurso narrativo, a etapa da potencialização, que integra 
a composição do esquema da existência, ocupando o lugar da não conjunção do sujeito com o objeto de valor (pp. 134-135). Assim, o que se considerava, dentro da obra do professor lituano, como um "caminho" de três etapas (manipulação, ação e sanção), é tomado como um sistema quaternário, funcionando dentro da lógica de funcionamento do quadrado semiótico.

Em um primeiro momento, aborda-se a etapa da virtualização. A seção inicial, “3.2.2.1 Querer-fazer", procura estabelecer as bases para a depreensão das principais ocorrências dessa modalidade nos discursos analisados. Após isso, realizam-se algumas colocações com respeito à confrontação entre o querer e o poder-fazer. Em seguida, a discussão é dedicada aos pontos de encontro entre a potencialização e a motivação do fazer. O foco dirige-se, um pouco adiante, às homologações modais travadas pelas categorias deônticas. Nesse ponto, aborda-se o assunto da atualização, de maneira incidental. Terminados esses comentários, a atenção é dirigida de forma mais integral à competencialização, dividida em um momento dedicado à observação da discursivização de suas ocorrências e em outro que trata o papel do saber na aquisição de emancipação pelos jovens entrevistados. Um momento final sistematiza as conclusões realizadas em cada parte da seção "3.2 Virtualização e atualização".

\subsubsection{Querer-fazer}

Barros (2002, p. 53) traz um encaminhamento para a problemática postulada por Greimas e Courtés (2012, p. 406), quando estes afirmavam que a semiótica de então não estava em condições de oferecer uma terminologia à lógica volitiva. A autora denomina as posições querer-fazer e não-querer-fazer, respectivamente, como "vontade ou volição" e "má vontade ou nolição". No que toca ao querer-não-fazer e ao não-querer-não-fazer, propõe que estes se chamem "abulia" e "vontade passiva", também respectivamente. Como alternativa terminológica às posições do quadrado do querer-fazer, propõe-se aqui a utilização da nomenclatura abaixo, trazendo uma outra forma de nomear alguns dos valores modais volitivos. 


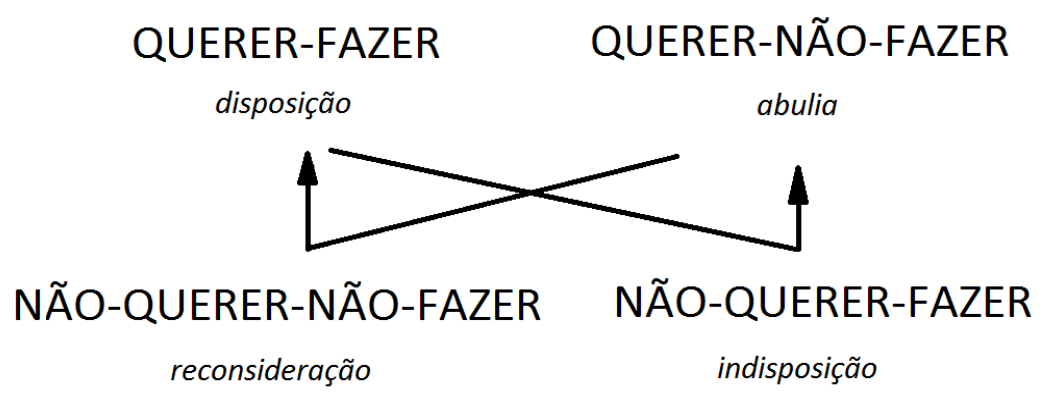

Figura 8 - quadrado do querer-fazer

Reconhecendo-se a "falibilidade" das denominações postas acima, dado ser uma iniciativa ainda experimental, ainda assim não parece incorreto valer-se dela para o presente trabalho, tendo em vista a farta ocorrência da modalidade volitiva nos textos analisados e, consequentemente, a oportunidade de verificação do funcionamento da terminologia proposta no âmbito deste estudo. Assim sendo, seguem as explicações para cada posicionamento.

O estado de conjunção com o valor modal do querer-fazer, equivale ao que se propôs denominar disposição, um estado de "abertura" volitiva do sujeito para o fazer. A partir da negação dessa atividade, chega-se ao conceito de indisposição, que seria como um "fechamento recente" do sujeito diante da ação. Para o querer-não-fazer, implicação do não-querer-fazer, manteve-se a formulação de Barros (p. 53), abulia. Esta diferencia-se da indisposição por ser, contrariamente, uma "disposição" do sujeito para a "não ação". Por fim, o termo reconsideração foi a melhor formulação encontrada para designar a posição esquerda inferior do quadrado modal volitivo. Essa escolha parece responder especialmente bem à ideia de negação da negação, na qual se situa. A elaboração da terminologia acima foi realizada a partir das reflexões sobre o quadrado semiótico realizadas por Bertrand (2003, p. 176). Na obra citada, o autor realiza um resumo didático a respeito do funcionamento do dispositivo teórico e auxilia na compreensão da história de tal metodologia, que é uma das bases fundantes do instrumental da semiótica.

Posto isso, segue o panorama de temas e figuras. A escolha metodológica feita no momento privilegia a obtenção de uma visão de cada articulação da categoria volitiva, segundo a classificação dos elementos discursivos. Os temas, distribuídos em menor número na coluna do meio, estão muitas vezes vinculados a mais de uma figura. As construções figurativas encontram-se na coluna da direita. 


\begin{tabular}{|c|c|c|}
\hline Modalidades & Temas & Figuras \\
\hline \multirow[t]{6}{*}{ Querer-fazer } & Formação & $\begin{array}{l}\text { Cursar universidade } \\
\text { Multiplicar formação } \\
\text { Transformação social }\end{array}$ \\
\hline & Transformação & $\begin{array}{l}\text { Servir de inspiração a outros jovens } \\
\text { Multiplicar formação } \\
\text { Transformação social } \\
\text { Trabalhar no terceiro setor } \\
\text { Trabalhar como autônomo } \\
\text { Mudar a história da família } \\
\text { Construir os seus sonhos }\end{array}$ \\
\hline & Habitação & Morar em casa de laje \\
\hline & Profissão & $\begin{array}{l}\text { Servir de inspiração a outros jovens } \\
\text { Multiplicar formação } \\
\text { Trabalhar como autônomo } \\
\text { Viajar a outros países, estados, cidades }\end{array}$ \\
\hline & Lazer & $\begin{array}{l}\text { Promover e participar de saraus e debates } \\
\text { Ser artista } \\
\text { Passear no bairro onde se mora } \\
\text { Viajar a outros países, estados, cidades } \\
\text { Nadar }\end{array}$ \\
\hline & Relacionamentos & $\begin{array}{l}\text { Namorar } \\
\text { Ter amigos }\end{array}$ \\
\hline \multirow[t]{6}{*}{ Não-querer-fazer } & Formação & $\begin{array}{l}\text { Estudar } \\
\text { Ganhar bolsa em escola particular }\end{array}$ \\
\hline & Profissão & Trabalhar em regime CLT \\
\hline & Habitação & $\begin{array}{l}\text { Morar sozinho } \\
\text { Morar em local inadequado (barraco, insalubridade) }\end{array}$ \\
\hline & Tristeza & Morte de familiar \\
\hline & Lazer & Nadar \\
\hline & Violência & Abuso sexual \\
\hline \multirow[t]{3}{*}{ Querer-não-fazer } & Violência & $\begin{array}{l}\text { Não vivenciar rejeição por parte de colegas } \\
\text { Não ter que conviver com violência policial }\end{array}$ \\
\hline & Formação & Não vivenciar bagunça na escola \\
\hline & Transformação & Não ter que usar ônibus lotado \\
\hline \multirow[t]{3}{*}{$\begin{array}{l}\text { Não-querer-não- } \\
\text { fazer }\end{array}$} & Formação & $\begin{array}{l}\text { Falta de estudo na família } \\
\text { Ter acesso à cultura }\end{array}$ \\
\hline & Lazer & $\begin{array}{l}\text { Transitar pelo centro da cidade } \\
\text { Viajar para outros países, estados, cidades }\end{array}$ \\
\hline & Habitação & Morar na casa dos pais \\
\hline
\end{tabular}

Quadro 3 - práticas de emancipação vistas sob a ótica do querer-fazer 
À primeira vista, há um quadro até certo ponto equilibrado, com um peso quantitativamente maior de figuras relacionadas à categoria do querer-fazer. Alguns temas repetem-se em diferentes linhas do quadro. Isso deve-se ao fato de terem sido abordados mais de uma vez no corpus, recobertos por diferentes figuras e estando, em cada momento, investindo um tipo distinto de modalidade. É o caso do tema "formação", que é o mais polivalente, pois chega a ser abordado pelos entrevistados em todos os desdobramentos da categoria do querer-fazer. Outras instâncias temáticas acontecem com mais direcionamento modal.

Ao observar-se a modalidade do querer-não-fazer, verifica-se uma sequência de figuras iniciadas pelas sequências de palavras "não vivenciar" e "não ter que". Estas expressões que antecedem as figuras discursivas da abulia foram tidas como as melhores formulações linguísticas encontradas para expressá-las. Isso ocorre porque há, nesses casos, no nível narrativo, além da categoria volitiva, uma confrontação modal. Trata-se da contradição entre as categorias querer-não-fazer e dever-fazer, homologação de incompatibilidade contraditória, encontrada em Greimas, também denominada resistência ativa pelo autor (2014, p. 98). Nesses casos, a configuração volitiva está ligada ao ponto de vista do sujeito, e a transferência do valor deôntico a cargo do antidestinador. A contradição que permeia estas duas modalidades é a responsável pela tensão gerada entre o programa e o antiprograma narrativos. Voltando aos comentários gerais sobre o quadro, no nível discursivo, cada manifestação textual traz uma forma diferente de lidar com a situação e de dar encaminhamento aos obstáculos que surgem, variando, por exemplo, no que tange às suas determinações fóricas.

\subsubsection{Contrariedade entre querer e não-poder-fazer}

Se, como visto, a confrontação contraditória entre as modalidades do querer e deverfazer tem uso no momento de se analisar os temas e figuras do querer-não-fazer, a homologação contrária entre as modalidades e derivações do querer e do poder-fazer possui, igualmente, importância para as análises que seguem. Foram aqui utilizadas a partir de uma metodologia empírico-dedutiva, na realização de uma confrontação de modalidades baseada naquela proposta por Greimas (pp. 94 - 95). 


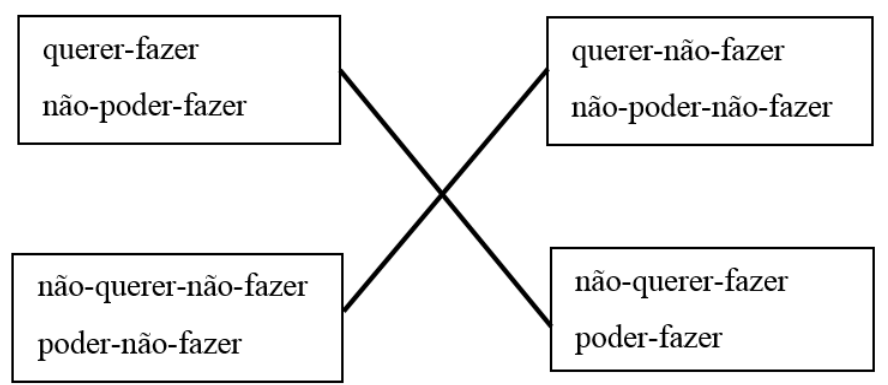

Figura 9 - Incompatibilidade e contrariedade entre querer e poder-fazer

$\mathrm{Na}$ análise do corpus, sobretudo quando se observam as figuras discursivas associadas ao querer-fazer, pode-se verificar que há menção recorrente à presença do não-poder-fazer (impotência). Essa última categoria atua como um obstáculo à ação e o seu estabelecimento leva à iminência de fracasso do PN. O sentimento negativo decorrente da não realização desses programas é frequente nas entrevistas e remete a antiprogramas de privação (ou de virtualização transitiva), cujo investimento figurativo varia de caso a caso. De modo geral, podese dizer que a combinação da disposição com a impotência gera uma incompatibilidade que é resolvida de diferentes maneiras em cada texto.

Um exemplo disso encontra-se no âmbito das experiências educacionais dos familiares dos jovens, que muitas vezes não tiveram a oportunidade de completar o segundo grau. JS23 e SM28 declararam que as pessoas mais velhas de suas famílias não haviam podido se formar no ensino superior. Como se vê no relato do primeiro deles, que se transcreve abaixo, a particularidade de que seja ele o primeiro representante da família a ingressar em uma universidade dá a essa formação uma importância a mais dentro da aquisição de saber que vivencia ("cursar faculdade").

"eu queria mudar a história da minha família porque eu venho de uma família que ela: vem de classe baixa e:: que nenhum dos meus familiares cursaram a faculdade ainda né?... eu sou o primeiro a entrar em uma faculdade... e:: falei... bom... quero: ser o primeiro quero... um dia entrar... porque: ou / outras pessoas da minha família e outros... tipo o meu filho ou o filho da minha irmã... os meus sobrinhos... possam estar dentro de uma faculdade ou estar 
querendo alguma coisa diferente do que aquela:... do que a vida que meus pais tiveram..." (Anexo, JS23, p. 9, grifos nossos)

Como se pode depreender a partir do trecho transcrito, JS23, ao cursar a universidade, difere de seus parentes, que não puderam estudar. Teoricamente falando, não haveria a necessidade de se reconhecer, nessa passagem, a presença de confrontação modal. Seria possível interpretar que há dois sujeitos distintos (um investido pelo ator "JS23" e outro pelo ator "familiares") que realizam percursos independentes, em dois programas narrativos autônomos no âmbito de um mesmo trecho de texto. Mas, ao se observar cuidadosamente o texto, nota-se que há elementos que não se explicam somente por essa interpretação.

A relação entre os dois atores ("JS23" e "sua família") remete a um vínculo afetivo e mostra que o primeiro sente-se um pouco como o continuador do processo de ascensão social e cultural de seus familiares. Isso poderia levantar a hipótese de que, sob um certo ponto de vista, o personagem JS23 não é o único ator que realiza a ação de estudar. Desse modo, a família "acompanharia" (em um nível afetivo) a ida à faculdade com o jovem. Em outros termos, podese dizer que é como se a construção actorial "família" também fizesse parte do ator que investe o papel de sujeito operador da transformação "cursar faculdade". Paralelamente, o ator "JS23", mesmo sem ter vivenciado a impossibilidade de estudar, vincula-se ao ator "família" a partir de uma "solidariedade" quanto ao percurso "não poder fazer universidade". Essa aparente contradição analítica ajuda a vislumbrar, em um plano mais estrutural, o modo como o indivíduo mune-se dos valores que vêm do percurso de sua família e como esta projeta valores no primeiro.

Como o sujeito ("familiares de JS23") não entrou em conjunção com o saber-fazer (adquirido na universidade), sabe-se que uma experiência de privação foi vivenciada por ele. No plano factual, os cidadãos com menos acesso à educação historicamente vêm vivenciando mais restrições quanto às possibilidades de ocupação de cargos e desempenho de funções na sociedade brasileira. Nesse sentido, pode-se afirmar que a disjunção com o valor saber-fazer significa também não-poder-fazer em muitos aspectos. Do ponto de vista discursivo, as experiências que não puderam ser vivenciadas pelo ator "pais", de algum modo, atingem "JS23" e transmitem algo como uma "carga emocional", que afeta suas ações futuras.

Faz-se pertinente mencionar, para melhor compreensão das ocorrências textuais transcritas acima, as reflexões de Fontanille e Greimas (1993, pp. 21 - 40) sobre a epistemologia das paixões e, mais especificamente, sobre as precondições da significação. Ao considerar que 
existe um nível anterior às modalidades narrativas no percurso gerativo de sentido, os autores afirmavam a existência de "prefigurações tensivas das quatro modalidades" até então identificadas - querer, dever, saber e poder (p. 32). Estas, de algum modo, estariam relacionadas a uma "memória afetiva" e repercutiriam sobre o funcionamento passional das modalidades. Os autores propõem a distinção entre protensividade, orientação e devir, três conceitos que funcionariam como diferentes etapas no processo das precondições da significação (p. 33).

Ainda que não se tenha aderido totalmente à proposta feita pelos autores na obra em questão ${ }^{25}$, nota-se, no âmbito das análises feitas no presente estudo, que as declarações de JS23 remetem à existência de uma grandeza que o modelo do programa narrativo canônico não consegue explicar. Esta é proveniente de uma "historicidade" narrativa e acarreta maior intensidade nas ações a serem executadas pelo sujeito.

Descrevendo a maneira como a massa tímica ainda pouco definida das sensações e dos sentimentos converte-se em conteúdo modal, entre o período da protensividade e o início do programa narrativo, Fontanille e Greimas estabelecem as bases que permitem que sejam compreendidas as diferenças de intensidade nos discursos. Esta instância reconhecida, se vista sob uma organização narrativa, virá a reger o estatuto modal dos estados e fazeres dos sujeitos, de acordo com a força que possuía quando ainda era uma "sombra de valor", que se relacionava a um quase-sujeito (p. 42). Assim, é na fase do contato com os conteúdos da linguagem e do mundo que um dado sujeito define o seu vínculo afetivo com eles. O "grau de potência" de sua massa tímica influencia a sua modalização e, consequentemente, a sua performance. Os dois programas que vinham sendo identificados no trecho de corpus anteriormente analisado podem ser identificados como uma transferência do "valor do valor". O sofrimento gerado pelo fracasso do PN inicial, de privação, transfere-se ao sujeito sob a forma de uma carga afetiva.

Todos os jovens entrevistados trazem, em algum ponto de suas falas, referências textuais que permitem detectar a presença de valores narrativos de não-poder-fazer. Remetem a experiências de vida, tanto suas, como de seus familiares ou de pessoas com as quais se identificavam e que se viram impotentes diante de situações variadas. A memória das privações de algum modo Ihes é transmitida, inspirando-Ihes a não repetir os erros do passado, a não ficar parados diante dos mesmos obstáculos, ou ainda, a ir cada vez mais longe em seus objetivos de vida. Há um trecho de texto especialmente representativo desse mecanismo de construção narrativa. Nele, SM28 expõe seu pertencimento a um parentesco e a uma identidade racial. Esse

\footnotetext{
${ }^{25}$ Algumas incorreções conceituais que ocorreram no âmbito de Semiótica das paixões acabaram por comprometer a coerência interna de funcionamento da teoria o que dificulta a adesão às ideias da obra como um todo.
} 
vínculo confere mais tônus ao êxito pessoal da narradora, por meio de mecanismos de significação que se analisam em seguida.

"quando eu / quando eu / eu vou: estudar: dos / dos processos de equidade de gênero... penSAR... é:... na pirâmide mesmo dos empre:gos e salários... eu descubro que: a mulher recebe mais / recebe menos do que os homens e que a mULHER NEgra recebe menos que as mulheres brancas... então a gente tem uma escala de quatro e eu sou / e eu sou: o / a última né? na escala... e quando eu / eu olho pro meu entorno familiar e e percebo que:... da / do lado do meu pai eu sou a / a primeira pessoa a chegar numa universiDAde... quando eu olho para a minha história... de gerações e / e / e: descubro que: / que eu sou:... a primeira geração da minha família que não passou fome... é::... pós-escravidão... eu conCLUO que tem uma coiSA erRAda aí... ne / nessa conta... né? não está somando no meu processo de / de: / de enquanto mulHER... uma que eu sei... e daí... se eu olho se eu vou olhar: para / para a realidade brasileira... e eu sei que eu sou uma privilegiada... enquanto mulher negra de ter acesso à universiDAde ter acesso à / à empre:go a poder me sustentar:..." (Anexo, SM28, p. 18, grifos nossos)

A inserção social exposta no trecho remete a uma construção de sentido mais complexa do que aquela trazida por JS23, pois é realizada não apenas no âmbito da família, como no caso que se examinou anteriormente. Em termos semióticos, isso justifica-se por uma maior riqueza do processo de actorialização do sujeito. A descrição textual remete a uma localização do ator nos campos familiares, geracionais, étnicos e de gênero. Além disso, a entrevistada relaciona esses pertencimentos a fatores de exclusão, somando a isso o fato de ser representante de grupos aos quais historicamente vem sendo imputadas possibilidades mais restritas na sociedade. A gradual especificação identitária por parte da narradora, do ponto de vista tensivo, tonifica cada vez mais o seu relato, pois ser bem-sucedida ocupando este lugar dentro da distribuição de desigualdades sociais mencionadas, é mais surpreendente do que sob outras condições. Em termos tensivos, pode-se dizer que a improbabilidade de êxito do programa narrativo configura o caráter concessivo da passagem, aumentando, simultaneamente, a intensidade da conjunção. O sujeito está agindo, nesse momento, segundo o modo de eficiência do sobrevir, que, segundo Zilberberg (2011) remete à elevação das subdimensões do andamento e da tonicidade, que causam uma "veemência afetiva" (p. 277).

A disposição tensiva acima mencionada constrói-se a partir do reconhecimento de dois PNs "possíveis" (dos quais apenas um se efetiva). No primeiro deles, antiprograma, há dois 
enunciados modais contrários em vigor. De um lado, há um não-poder-fazer (impotência), e, de outro, um querer-fazer. O sujeito é investido por um ator coletivo ("familiares", "mulheres", "pessoas negras em geral" e, consequentemente, "SM28") e sua actorialização é fortemente marcada pela privação. Caso esta chegasse a se efetivar, culminaria no fracasso da consecução dos objetivos do sujeito, levando à disforia. Esse antiprograma é regido pelo princípio implicativo (modo do pervir), uma vez que ele está marcado pela ideia de previsibilidade (p. 271).

No segundo programa possível, um sujeito investido apenas pelo ator "SM28", influenciado pelo antiprograma, não se vê mais impotente diante do agir. Está cada vez mais disposto a aproveitar bem as suas chances de vida. Para poder entrar em conjunção com os valores desejados, a homologação de incompatibilidade e contrariedade (Figura 9, presente estudo) precisa passar por alterações. A confrontação modal que irá permitir a realização do programa, nesse caso, é a compatibilidade entre querer e poder-fazer. Este segundo percurso é eufórico, mais marcado pela concessão e pelo modo do sobrevir (p. 277).

A construção de imagem de SM28 como uma pessoa "fora das estatísticas", no sentido de que pôde fazer algo que muitos outros indivíduos próximos não puderam realizar, singulariza sua trajetória, e traz mais destaque a seu discurso. Ao mesmo tempo, a unicidade de seu êxito é uma denúncia social, pois revela a lógica de previsibilidade perversa que se aplica ao percurso de jovens negros e de periferia no Brasil.

A contrariedade entre as modalidades do querer e do poder-fazer estão relacionadas com a condição inesperada da emancipação de SM28. No nível narrativo, o sujeito encontra-se diante de um antidestinador narrativo que torna improvável a realização do $\mathrm{PN}$, chegando ao ponto de soar impossível (dever-não-ser) que venha a ter êxito. Caso essa restrição chegasse ao ponto de "atingir o espírito" ${ }^{26}$ do sujeito, ela viria a configurar um não-poder-ser.

Indo em direção a outro relato, JS23 traz, em seu depoimento, alguma reflexão sobre o seu ingresso e manutenção dentro da faculdade. Ao fazê-lo, o jovem ressalta a importância de ter assumido as despesas referentes ao custo de seu transporte para a instituição em seu processo de aquisição de emancipação.

"eu fiz meu primeiro vestibular e me $\mathrm{f} / \mathrm{e}$ saiu o resultado positivo e: meus pais falaram que (eu) não podia pagar a condução para mim, não ia poder cursar a faculdade aí eu falei eu

\footnotetext{
${ }^{26}$ Fiorin $(2012$, p. 121) levanta a possibilidade de associação da modalidade do dever a um determinismo das coisas e a do poder a um determinismo do espírito.
} 
não posso cobrar dos meus pais isso... eles me deram uma educação boa... me deram um âmbito familiar muito: / muito bom... nunca deixaram eu passar fome... depois pelo outro lado eu estava passando em um dos vestibulares mais concorridos e eu queria cursar de qualquer jeito... e meu pai falou 'pô não tem como a família bancar isso' aí foi por isso que eu decidi mesmo ser emancipado... eu queria começar a me é:... a me bancar... financeiramente e queria ajudar mais meus pais... \{E: legal / legal... \{J: aí daí / aí daí veio / veio vários rompiment / vários / várias / várias barreiras que eu quebrei de começar a sonhar com os próprios sonhos começar a estipular metas que eu queria ir atrás... busCAR novos caminhos... sair da zona de confort / da zona de conforto..." (Anexo, JS23, p. 10, grifos nossos)

Verifica-se que a falta de dinheiro, até um dado momento da narrativa, investia semanticamente o valor de uma impotência, não-poder-fazer. Como o próprio entrevistado conta, após ter passado no vestibular, não dispunha de meios para pagar a condução até a universidade. Quando consegue custear o próprio trajeto, no nível narrativo, o quadro modal é revertido e o sujeito entra em conjunção com o poder-fazer.

Essa passagem significou o marco inicial de um processo de emancipação que transcende o âmbito da problemática na qual surgiu. Ou seja, a vitória sobre a dificuldade pontual dos custos de transporte simbolizou, de certa forma, o começo de um movimento geral de busca por independência por parte do ator "JS23". Esse processo de emancipação é denominado por ele "saída da zona de conforto", ação tratada de maneira eufórica. No nível narrativo, essa transição remete ao ingresso do sujeito no regime de manipulação reflexiva que conduz, a partir daí, o fazer do desenvolvimento narrativo. Do ponto de vista das categorias veridictórias, trata-se da descoberta da falsidade de um não-poder-fazer, que era ilusório (parecer e não-ser). Tal alteração de estatuto revela um poder-fazer que estava oculto (nãoparecer e ser) e que se mostra verdadeiro (parecer e ser) a partir da conscientização do sujeito a respeito de suas próprias potencialidades.

\subsubsection{Contraditoriedade entre querer-fazer e poder-não-fazer}

Não é somente por meio da temática das formações escolares e de ensino superior que os jovens entrevistados referem-se ao que se denomina valor de impotência, ou não-poderfazer. $\mathrm{O}$ universo da cultura periférica, tal como construído pelo discurso de AV24, identifica 
obstáculos variados, como as más condições de moradia, trabalho e saúde. Todos esses temas apontam para o valor modal em questão. Porém, ao tomar consciência sobre a situação precária na qual vive, o entrevistado instaura, em sua fala, uma nova forma de encarar os impedimentos. No nível narrativo, essa conscientização parece corresponder a uma transição na direção do valor de poder-não-fazer (independência), a implicação natural do não-poder-fazer. Em mais de um extrato de texto, a capacidade por parte do ator "AV24" (e seus companheiros de luta e de engajamento) de enfrentar e vencer as adversidades do cotidiano na periferia (antiprograma narrativo) é evocada euforicamente. Como diz o entrevistado:

“a questão da emancipação da periferia sempre tá ligado a questões econômicas... sempre está ligado à questão de superação de... de algumas... de alguma violência social... que no caso essa violência social está retratada em você... é:... não estar morando na beira do córrego... né... de você transformar sua casa de barraco numa casa de/de... de madeira numa casa de bloco... de você não ter telha mas de você ter uma... uma laje... tá ligado?" (Anexo, AV24, p. 1, grifos nossos)

Viu-se, no capítulo anterior, que, para o discurso do entrevistado, o processo de emancipação do jovem de periferia, visto como ator coletivo, encontra-se ligado a uma busca, contínua, pela melhoria das condições de vida. O tema da moradia é especialmente significativo nesse sentido, por tratar de uma discursivização que remete fortemente à construção de identidade, afinal, as pessoas definem-se, ao menos parcialmente, pelos locais nos quais habitam.

Segundo a narratividade do trecho em questão, o antiprograma ("seguir morando em barracos") é visto como disfórico pelo sujeito ("AV24"). As figuras "casa de madeira ou de bloco" ou "telhado de laje" investem, discursivamente, a modalidade do poder-não-fazer, ou a afirmação da independência diante da impotência prevista pela continuação das disposições narrativas que se encontravam em vigor. Ao caminhar no sentido oposto ao do antiprograma, 0 sujeito também busca rejeitar a conjunção com os antiobjetos ("vulnerabilidade" e "desprestígio social"), dos quais deseja distanciar-se. Vê-se que, no discurso de AV24 (que está sujeito a ter semelhanças com outros discursos de jovens da periferia de grandes centros urbanos), a emancipação requer o embate com um antidestinador pouco concreto em termos discursivos ("a sociedade", "as pessoas ricas"), mas de influência indiscutivelmente forte. 
Outra modalidade presente na ação do antidestinador dessa passagem é o valor de necessidade (dever-ser) ou, ainda, o de não-poder-não-ser ${ }^{27}$, a inevitabilidade da ocorrência. Em termos discursivos, isso corresponderia a algo como uma "predestinação" por parte das pessoas que habitam nas periferias de viver em más condições. Tal disposição modal (não-poder-nãofazer) é investida no discurso pelo tema da desesperança. A emancipação de AV24, contrária a esse encaminhamento, pode ser lida narrativamente como um movimento de contraposição ao antiprograma, fazendo uso das estruturas modais do poder-não-ser e do não-dever-ser (contingência, segundo Greimas, 2014, p. 90), o que afirma, discursivamente, a esperança.

\subsubsection{Motivação e fidúcia}

Para dar prosseguimento ao estudo do corpus, os elementos narrativos da motivação e da fidúcia são abordados. Considera-se, nesse momento, a temática das viagens, vista, muitas vezes, como uma fonte de estímulo pessoal pelos discursos. JS23 diz, em trecho já mencionado no tópico anterior, que, caso frequentasse uma escola particular, se sentiria frustrado por não realizar as viagens ao exterior que seus colegas de escolas particulares fariam. Nesse caso, em um plano narrativo, haveria o que se pode denominar estabelecimento de um percurso narrativo passional, a insatisfação (a privação do objeto, segundo Barros, 2002, p. 64), desmotivando o sujeito a agir.

SM28, por sua vez, menciona que as viagens que fez com a escola em meio a programas de protagonismo juvenil a fizeram "despertar para várias outras coisas", em um movimento que se pode denominar narrativamente como um programa de aquisição de saber (Anexo, SM28, p. 18). A título de contextualização, grosso modo, esse tipo de viagem corresponde a atividades de cunho social e de formação voltadas ao segmento jovem, com o objetivo de estimular os seus sensos de liderança e protagonismo. Os deslocamentos feitos no âmbito desses projetos, aproximam-se do que se denomina modalidade narrativa do saber, pois levam os indivíduos a entrar em contato com coisas novas. Tal "desvelamento de mundo" - assim como aquele proporcionado pelas experiências turísticas, pode ser considerado um movimento de abertura, pois permite que interesses por assuntos que antes não eram conhecidos se desenvolvam.

Para o entrevistado AV24, as viagens são igualmente bem-vistas. Ao mencionar algumas pessoas que lhe servem de referência (indivíduos que o motivaram a se emancipar), cita um colega que "saiu andando pelo Brasil", em um movimento aventureiro em busca de encontros que trouxessem outros sentidos para a vida. A sua fonte de inspiração na obtenção de

\footnotetext{
${ }^{27}$ Greimas (2014, p. 95), ao confrontar as modalidades do poder e do dever-ser localiza a relação nãopoder-não-ser / dever-ser (necessidade) no quadro de homologação da compatibilidade e conformidade.
} 
independência está associada a cada um desses personagens. $\mathrm{O}$ ato de uma pessoa admirar alguém ou suas ações pode significar, do ponto de vista narrativo, uma vinculação entre destinatário e destinador (manipulação).

\footnotetext{
"a gente tem um respeito muito grande por essas pessoas assim que têm uma caminhada que... que já fizeram várias coisas... uma já teve bar outra já teve: / já saiu andando pelo Brasil tá ligado? e elas foram ganhando a vida delas assim né? então é isso né?... são as pessoas do meu dia-a-dia que me inspiraram..." (Anexo, AV24, p. 3, grifos nossos)
}

AV24 também fala das viagens à Brasília, as quais realizou como meio de ativismo político. Conta que faz esse tipo de deslocamento com certa frequência. Durante uma dessas experiências relatou ter sido vítima de preconceito racial (a única referência disfórica do tema das viagens no corpus). No trecho mencionado, um atendente de hotel recusou-se a atendê-lo por ele ser negro.

A principal modalidade narrativa que se associa ao domínio semântico das viagens no corpus é a modalidade do querer-fazer. Muitas vezes é por meio do viajar que os jovens reafirmam a sua disposição de dar continuidade aos seus processos de emancipação. Além disso, a motivação dos entrevistados é também permeada frequentemente pela inspiração de outros jovens ou adolescentes em suas trajetórias, tomada aqui como uma espécie de "reforço tímico" que traz tonicidade à categoria em questão. Esse "reforço" também pode ser descrito analiticamente como uma manifestação das modalidades potenciais (Fontanille e Zilberberg, 2001, p. 256). Na obra citada, os autores ressaltam a importância dessas categorias dentro do percurso gerativo de sentido dizendo que "não basta que o sujeito disponha de todas as competências virtualizantes e atualizantes para que aja e se realize. É preciso também que ele creia querer, creia dever, creia saber e creia poder" (p. 254, grifo dos autores). Ou ainda, colocam que "o crer é então a modalidade que corresponde para nós ao modo potencializado, a primeira etapa da construção da competência, a partir da qual todas as outras modalidades poderão se desdobrar" (p. 255).

Antes de entrar na análise da fidúcia das passagens em questão, é importante mencionar que, para tal descrição, o verbete das modalidades epistêmicas (encontrado em Greimas e Courtés, 2012, p. 172), já utilizado no âmbito da análise da confiança de Sundjata (cf. capítulo 1 do presente trabalho), segue sendo de utilidade. Além dele, a proposta de Fontanille e Zilberberg (2001), de considerar o crer como parte de um complexo discursivo que compreende o saber e o conhecer é também adotada (p. 265). Vale a pena examinar de uma 
maneira um pouco mais detida essas duas formas de compreensão semióticas da problemática do crer.

Ainda que não venham de um mesmo "momento" da teoria (a data de publicação do Dictionnaire raisonné de la théorie du langage é 1979 e a de Tension et Signification, 1998), as duas abordagens do assunto não são incompatíveis, podendo ser vistas como complementares. Greimas e Courtés (2012, pp. 172-173) dedicaram-se à articulação da modalidade epistêmica a partir da metodologia do quadrado semiótico, distribuindo-a nas quatro posições habituais (crer-ser, não-crer-ser, crer-não-ser, não-crer-não-ser ${ }^{28}$ ), constituindo com elas o que chamam de estrutura modal epistêmica. Além disso, afirmaram o traço "gradativo" das modalidades epistêmicas. Segundo esse princípio, elas podem ser vistas em contraste com as categorias aléticas, que são chamadas de contraditórias, no sentido de que excluem qualquer gradiente.

Posteriormente, com a formulação do esquema de presença, no qual a categoria da potencialização desempenha papel fundamental, o crer adquiriu um lugar mais próprio no percurso gerativo do sentido (Fontanille e Zilberberg, 2001, pp. 123-147). No livro, ela foi desdobrada em assumir e aderir, segundo a sua utilização por forças endógenas ou exógenas ao sujeito (p. 256). No que tange a essa categoria, os autores de Tensão e Significação não chegam a propor encaminhamentos específicos para as suas articulações com as modalidades do ser e fazer, mantendo-se em uma explicação geral do fenômeno (p. 266). Trata-se de um tópico ainda controverso em termos teóricos, contudo, é importante debatê-lo, uma vez que valer-se dele é importante para a descrição do processo emancipatório.

Além das propostas mencionadas acima, o quadrado da agitação e do crer intersubjetivo, também elaborado por Fontanille e Zilberberg (p. 267), faz-se pertinente para a compreensão do fenômeno narrativo da modalização epistêmica, que envolve a aquisição de emancipação trazida pelo discursos dos jovens entrevistados.

\footnotetext{
${ }^{28}$ Figura 5, Modalidades epistêmicas, presente trabalho.
} 
INQUIETAÇÃO

agitação decorrente do temor
FIRMEZA

qualidade daquele que não se abala

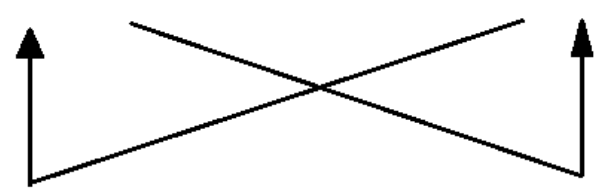

MEDO

emoção decorrente da tomada de consciência de um perigo

\section{SERENIDADE}

estado tranquilo, sem agitação

Figura 10 - Categoria da agitação

Esclarecidos alguns dos termos que regem a modalidade do crer, pode-se retomar a análise de textos do corpus. A entrevistada SM28, por meio de seu discurso, demonstra dispor de certa segurança quanto à sua colocação profissional. Diz que é apaixonada pela possibilidade de transformação e vê a si mesma como uma agente de mudança social, que tem o poder de fazer com que o mundo ou o seu entorno seja diferente (Anexo, SM28, p. 15). Além disso, conta que, com treze ou quatorze anos, trabalhando socialmente, já fazia campanhas para que as pessoas doassem sangue, uma vez que ela mesma ainda não tinha idade suficiente para fazê-lo. Há também uma interessante passagem na qual relata que era briguenta, e que foi perdendo essa característica conforme atingia a adolescência.

“sempre fui muito briguenta... é:... desde pequena... primeir / antes de entender do: / briguenta de bater mesmo:... me xingavam eu batia... mas depoi / depois de adolescente já era um briguenta de discutIR de questionAR e teve uma época da minha vida que eu dei uma paRAda assim uma aPAGAda nisso... fiquei meio / meio dePRÊ meio... meio... meio não questionadora... e aí... aí uma professora uma vez me chamou e falou assim 'S... porque que você deixou de ser briguenta por que que você parou de questionar? porque que você:... é:: se escondeu' né?... e isso:... reverberou na minha vida... depois dessa conversa... e aí:... voltei a ser / ser briguenta mas (dessa vez) de / de um / de um jeito:... diferente... por /por buscar mais... os meus objetivos as minhas vontades..." (Anexo, SM28, p. 19, grifos nossos)

Se o querer é a modalidade narrativa que permeia as ações do ator "SM28", este valor narrativo está vinculado discursivamente à transformação social. Na passagem acima transcrita, vê-se que a vitalidade da protagonista encontra-se ligada à capacidade de "brigar" pelos seus sonhos e de atuar nesse tipo de militância. A base que fundamenta as ações desse ator está muito fortemente vinculada à convicção (crer) de estar atuando pela mudança do mundo. Além 
disso, pode-se afirmar que, nessa passagem, no plano narrativo, a aquisição do crer do sujeito ("SM28") dá-se por uma manipulação reflexiva. $\mathrm{O}$ ator discursivo, nesse extrato de texto, investe os actantes destinador, destinatário e sujeito operador. Em termos correntes, isso corresponderia a dizer que a segurança desse indivíduo vem da sua autoconfiança.

Observando-se com mais atenção o trecho acima, vê-se que há, por parte do ator "SM28", certa relutância quanto à ação de questionar e lutar pelos seus ideais. Isso pode ser considerado, do ponto de vista narrativo, fruto de um contrato de manipulação estabelecido com o antidestinador. Mas, segundo outras possibilidades descritivas, tal passagem poderia referir-se, talvez com mais precisão, ao duvidar (não-crer-ser), categoria posicionada na etapa da potencialização. O quadrado da agitação, de Fontanille e Zilberberg (p. 267), traz ainda uma terceira possibilidade analítica, que determina o fenômeno como uma manifestação de "medo" (a negação da firmeza).

Voltando à passagem transcrita, a partir desse questionamento, segue um período difícil para a experiência subjetiva, regido pelo que se pode denominar um valor de não-querer-fazer figurativizado pelos temas do apagamento e da estagnação. Além disso, ocorre o que a entrevistada descreve como uma depressão. No nível narrativo, isso parece se relacionar à falta de confiança interna, que influencia negativamente a capacidade de agir do sujeito. Ao entrar em crise quanto às próprias capacidades, o ator "SM28" entra em contato com uma insuficiência que torna evidente a necessidade de alguma mudança em sua vida, que o auxilie em sua recuperação. Em termos narrativos, pode-se dizer, a partir da análise dessa passagem, que o destinatário precisa de um destinador mais tônico para seguir adiante.

É o ator "professora" que investe o papel desse destinador tônico, e faz com que a conjunção do sujeito com o querer-fazer ocorra, mesmo diante das dificuldades decorrentes da crise de confiança reflexiva. O novo contrato possibilita o reencontro do sujeito com o crer-ser, dando novas forças ao progresso do PN. Ao final da etapa de manipulação, há um novo momento do sujeito, renascido após o período de questionamento e inquietação. Por fim, ele chega ao que, no quadrado da agitação, denomina-se a serenidade. Após isso, movimenta-se novamente em direção à conjunção com o estado de firmeza, talvez ainda mais confiante que anteriormente. Tal constatação se vê expressa pela frase: "voltei a ser / ser briguenta mas (...) de um jeito:... diferente (...) por buscar mais... os meus objetivos as minhas vontades" (Anexo, SM28, p. 19). Essa última afirmação consolida o êxito do PN do sujeito, expresso no discurso da entrevistada. 


\subsubsection{Percurso "cíclico" de JS23}

Além das considerações de SM28, que, conforme analisado, ilustram a transição de um sujeito narrativo em conjunção com a inquietação até chegar à firmeza, o discurso de JS23 também traz considerações interessantes para a compreensão do fenômeno da motivação. $O$ entrevistado faz menção a uma força que o faz levantar-se da cama com energia para enfrentar os desafios da vida, construindo o que se configura como um percurso cíclico de estímulo e realização. Segundo o entrevistado, isso advém da natureza revigorante do trabalho que realiza junto a jovens em situação de vulnerabilidade social.

“... será que eu estou (indo) no caminho certo? será que... é: / será que é isso mesmo?... será que trabalhar numa empresa... maior de grande porte seria legal... estaria ganhando bem mas... talvez eu não estaria com esse sorriso... que eu tenho hoje... de todo dia... vim aqui e trampar mas acho que... momentos difícil ainda eu não passei e: e eu... todo dia quando eu levanto da minha cama... eu: ... venho trabalhar com... com... com: brilho nos olhos para minimizar isso né?” (Anexo, JS23, p. 10, grifos nossos)

Ao comparar sua profissão com outra mais bem remunerada, o jovem avalia positivamente o caráter social de seu trabalho. A felicidade de JS23 está intimamente ligada ao bem-estar de jovens que, como ele, passaram ou passam por dificuldades e situações de risco em seus processos de se tornar adultos. Nesse sentido, pode-se afirmar que há, aqui, a manifestação de uma modalidade narrativa volitiva que, para o sujeito ("JS23"), encontra-se em relação solidária com a sanção positiva que recebe do destinador-julgador ("jovens aos quais oferece formação"). O ato, como se verá adiante, funciona em meio a uma lógica de fortalecimento da confiança do sujeito em seu fazer.

Antes de entrar na discussão acima, faz-se pertinente refletir sobre um pressuposto do discurso, afinal, a mencionada disposição de acordar de manhã para trabalhar, por vezes, pode remeter à indisposição de se fazer isso. Além de significar o valor de não-querer fazer, essa mesma figura pode também investir a modalidade do querer-não-fazer. Isso aconteceria, por exemplo, em um discurso no qual um personagem se nega a trabalhar ou, ainda, despreza os assuntos relacionados a essa atividade da vida. A conotação ruim dada ao acordar e ao pôr-se a realizar os deveres cotidianos não é só encontrada nos discursos juvenis, como se vê abaixo.

Lopes e Tatit $(2008$, p. 85 - 88) ao tratar da análise semiótica da canção "Olé olá", de Chico Buarque, realizam uma interessante análise que estabelece a aliança do protagonista do texto com os valores da desaceleração e do alongamento. Esses são remetidos ao período 
noturno, criando uma dicotomia. O universo cultural do samba, de maneira geral (em especial nessa canção), parece pôr em contraposição a noite (o "domínio dionisíaco do samba e do prazer") e o dia (o "tempo regrado da sujeição ao duro e ao mau-remunerado trabalho"). Segundo a análise dos autores, esse é um dos principais pontos abordados pelo cantor e compositor carioca na canção.

JS23, como visto no extrato de fala acima, afirma ter descoberto uma razão e uma motivação para acordar cedo. A possibilidade de atuar junto dos jovens da sua comunidade faz com que ele se sinta bem, orientando-os no sentido de encontrar seus caminhos profissionais e pessoais, mesmo com a remuneração menor que recebe nessa profissão. No nível narrativo, um mecanismo de negação do querer-não-fazer leva o sujeito a não-querer-não-fazer e, por fim, a querer-fazer. Discursivamente, o ator "JS23" reverte o posicionamento disfórico normalmente atribuído ao ato de trabalhar. As figuras do "brilho nos olhos" ou do "sorriso", mencionadas pelo entrevistado, acompanham-no em seus ofícios cotidianos. Estas podem ser descritas pela firmeza no querer-fazer, segundo o termo do quadrado da agitação, visto acima.

Faz-se oportuno, nesse momento, levantar uma hipótese: seria o sujeito que quer fazer, após ter passado pelo questionamento do querer-não-fazer, mais tônico em sua disposição do que aquele que simplesmente quer, sem ter entrado em conjunção com essa negação?

“E: legal... é:: você se sente bem... sendo uma pessoa... autônoma? J: nossa ótimo assim... não por conta de não precisar de ninguém assim... eu pago as minhas contas eu sonho os meus sonhos assim... mas você se sente bem quando você vê a / algo: / tipo: que:... alguém / algum outro jovem olha para você e fala 'pô... se você conseguiu eu também consigo chegar lá...' então que nem eu trabalho muito com / com / com:... empreendedorismo social essas coisas e com: transformação de vida né?... que eu trabalho bastante com jovens em vulnerabilidade social... tem risco na socieda / tem risco na sociedade... quando um jovem fala 'pô você conseguiu mudar sua situação você escolheu... é:... trabalhar como educador... eu te tenho como / como esPElho...' é isso que eu sou:... / que sou mais grato assim nem é o salário que eu recebo nem é o:: as contas que eu tenho que / para pagar... os cursos que / que eu consigo bolsa... mas o sorriso do jovem falando (...) (eu) também posso conseguir... / também vou mudar minha situação' é o que paga (...)" (Anexo, JS23, p. 10, grifos nossos)

O trecho de entrevista acima ilustra, com bastante precisão, o grau de certeza que o sujeito tem quanto ao fazer. Fontanille e Zilberberg (2001, p. 265) dispõem os termos certeza, ceticismo, niilismo e conviç̧ão como os quatro termos da categoria epistêmica da crença. De destinador-manipulador que atribui valores de querer e dever (ser e fazer) ao destinatário 
("jovens alunos"), o ator "JS23" investe o papel actancial de destinatário e mune-se de um querer-fazer que é transmitido por outro destinador, investido pelo ator que antes tinha ocupado o papel de destinatário ("alunos"). Como se vê, uma variedade de funções é desempenhada por cada ator do relato.

O encadeamento de programas narrativos pressuposto por esse trecho de texto forma uma sequência que se inicia (é preciso começar de algum ponto), com a sanção de um destinador-julgador ("jovens já formados, alunos de JS23", satisfeitos com os aprendizados do curso). Esse mesmo ator investe o papel temático de destinador-manipulador do PN seguinte. Durante a manipulação desse programa, o destinatário ("JS23") está sincretizado com o sujeito do fazer. Com o fazer-fazer, ele nutre-se da confiança intersubjetiva acumulada pelo PN inicial ("primeira formação"), transferindo-a ao programa que segue ("nova turma"). A figura que investe discursivamente a ação do último PN corresponde à manipulação de um programa que na narrativa adquire uma importância secundária, investido pelas "atividades futuras dos alunos de JS23". Voltando à observação do programa de base, passada a etapa da manipulação, vê-se que, com o êxito dessa etapa, há o estabelecimento de uma segunda sanção. Nela, o destinatário-julgado ("JS23") obtêm, novamente, avaliação positiva de um destinador-julgador ("formandos da nova turma"). Automaticamente, a sanção se converte em nova manipulação e, assim, o sujeito tem alimentada a sua base fiduciária para mais uma realização... Com base nessa estrutura cíclica de funcionamento é que se explica o êxito profissional e pessoal do entrevistado, um mecanismo que transforma o destinador-julgador em manipulador do percurso seguinte.

\begin{tabular}{|l|l|l|l|l|l|l|l|}
\hline Etapa & Sanção & $\begin{array}{l}\text { Manipula- } \\
\text { ção }\end{array}$ & $\begin{array}{l}\text { Potenciali- } \\
\text { zação }\end{array}$ & $\begin{array}{l}\text { Virtuali- } \\
\text { zação }\end{array}$ & $\begin{array}{l}\text { Competen- } \\
\text { cialização }\end{array}$ & $\begin{array}{l}\text { Realiza- } \\
\text { ção }\end{array}$ & Sanção \\
\hline $\begin{array}{l}\text { Actan- } \\
\text { te }\end{array}$ & $\begin{array}{l}\text { Destinador } \\
\text {-julgador }\end{array}$ & $\begin{array}{l}\text { Destinador- } \\
\text { manipulador }\end{array}$ & \multicolumn{4}{|c|}{ Sujeito } & $\begin{array}{l}\text { Destina- } \\
\text { dor- } \\
\text { julgador }\end{array}$ \\
\hline Ator & $\begin{array}{l}\text { Jovens } \\
\text { beneficia- } \\
\text { dos }\end{array}$ & $\begin{array}{l}\text { Jovens } \\
\text { beneficiados }\end{array}$ & \multicolumn{2}{|c|}{ Jovem formador } & $\begin{array}{l}\text { Jovens } \\
\text { beneficia- } \\
\text { dos }\end{array}$ \\
\hline
\end{tabular}

Quadro 4 - Sequência narrativa da formação de jovens por jovens

Desse ponto de vista, é interessante notar como, para o entrevistado, o que inicialmente poderia ter sido tomado como uma dificuldade a mais no estabelecimento de seu caminho profissional - o fato de sua família pertencer a uma classe social baixa e de ter tido pouco acesso a bens materiais em sua infância - torna-se, contrariamente, um recurso para ele. A sensação de identidade que possui quanto à relação com seus alunos, faz com que se sinta um pouco mais "vitorioso" com o êxito de cada um de seus beneficiados. Esta "via de mão dupla" entre confiar 
e ser considerado confiável foi verificada no capítulo 1 do presente trabalho, na cena na qual Narê Maghan confia Balla Fassekê à Sundjata. Nela, verificou-se que os personagens Mari Djata, o rei, Nhankuman e Balla contagiavam-se uns com a confiança dos outros, em uma espécie de "cerimônia" de celebração da conjunção epistêmica.

Ao encontrar na realização dos outros jovens de periferia um estímulo e uma fonte de apoio para seu trabalho, o ator "JS23" efetua a mudança de sentido de um percurso descendente (momento não narrado, no qual ele estaria ainda incerto diante dos obstáculos da vida) para a ascendência (caminho do êxito profissional e da vitória sobre os percalços da existência).

A manipulação cíclica, mencionada acima, encontra-se igualmente evocada quando o entrevistado cita os "ídolos" que inspiraram a escolha de sua profissão. Todos eles tinham tido ações de destaque como multiplicadores de suas práticas (Anexo, JS23, p. 14). A principal diferença entre a ação de JS23 e a desses personagens que são referências suas é que os "formandos" dos últimos (os indivíduos que se beneficiam da prática da capoeira ou do futebol, por exemplo) prosseguem dentro do campo de atuação de seus "professores" ou "mestres". A estrutura desse programa narrativo remete a um desenvolvimento em descontinuidade actorial e continuidade espacial. O modelo de multiplicação que JS23 pratica é, entretanto, mais "desapegado", no sentido de que oferece orientação e formação a seus alunos sem que esses necessariamente comunguem de sua área de atuação (descontinuidade actorial e espacial).

AV24, em seu depoimento, igualmente refere-se a aspectos do trabalho que realiza dentro da comunidade na qual vive. Assim como JS23, encontra nela uma fonte de suporte afetivo para manter em atividade seu ofício.

"eu vou precisar de pessoas para me ajudar nessa fase entendeu?... (...) e a gente está vendo que o melhor caminho de buscar isso é estar... junto com as pessoas que... com os mestres né?... com os senhores com as senhoras... né?... que querem também legitimar a força dos jovens e apostam na juventude como continuidade da luta entendeu?..." (Anexo, AV24, p. 4 , grifos nossos)

Há no trecho, no nível narrativo, a configuração de uma espera pela comunicação de valores modais vindos do destinador. Contando com eles, o sujeito acredita que terá condições de superar os obstáculos vindouros, que, prevê, possivelmente abalarão a firmeza do querer ou do senso de dever-fazer, durante a execução do programa narrativo. 


\subsubsection{Dever e poder-fazer}

As confrontações acima observadas, feitas a partir das relações estabelecidas entre as modalidades do querer e do poder-fazer, podem ser complementadas por outra homologação, já relativamente explorada dentro da tradição dos estudos semióticos, aquela que se dá entre as modalidades do dever e do poder-fazer. Greimas e Courtés (2012, p. 374), em uma etapa inicial dos estudos das confrontações modais, afirmavam a proximidade que as duas categorias guardam entre si. Sugeriram que o dever e o poder fossem considerados como "instâncias autônomas" definindo-os como complementares - um virtualizante e outro atualizante - da modalização. Além disso, ressaltaram que a definição das relações hierárquicas dominante/dominado deveria levar em conta essa complementaridade modal. O quadro abaixo reproduz as articulações então feitas.

Compatibilidade e complementaridade

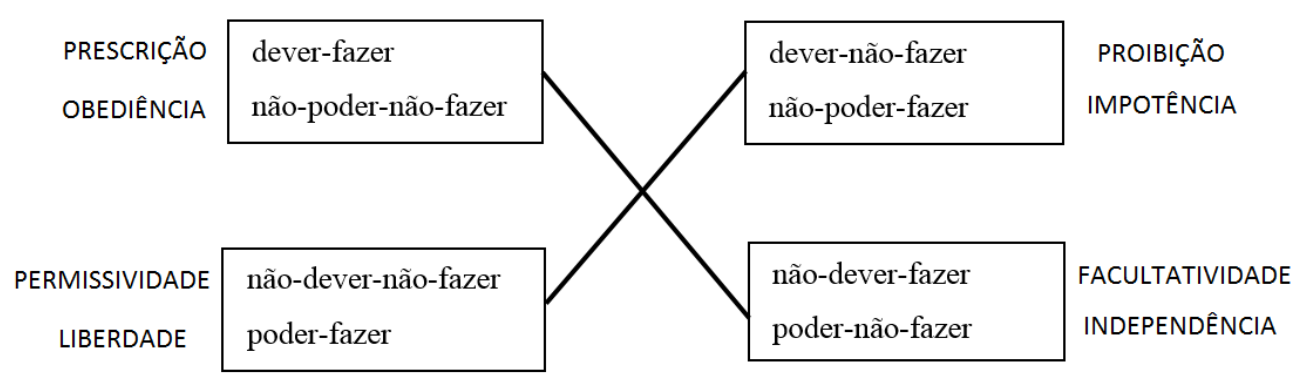

Figura 11 - Conformidade e complementariedade entre dever e poder-fazer

Fiorin (2012, pp. 121-122) colabora na diferenciação entre as duas modalidades (dever e poder), distinguindo dois modos de determinação, um vindo do sujeito e outro vindo do objeto. A distinção proposta também pode ser descrita pelas modalizações que se dão entre sujeitos (relações intersubjetivas ou de um sujeito consigo próprio) e aquelas que acontecem entre um sujeito e as coisas do mundo. 
Uma das consequências da constatação da complementaridade que há entre o dever e o poder é o fato de que a emancipação, aqui concebida inicialmente em termos de liberdade (poder-fazer) e independência (poder-não-fazer), precisa tomar como fundamentais a seu estatuto também as noções de permissividade (não-dever-não-fazer) e facultatividade (nãodever-fazer).

No corpus encontram-se manifestações narrativas de proibição (dever-não-fazer narrativo), que apontam ao impedimento de se realizar determinada ação. Um exemplo disso está no discurso de JS23 (Anexo, p. 11). O entrevistado conta que foi barrado pelo segurança de uma loja de brinquedos por ser negro. Este o tinha impedido de permanecer no estabelecimento, sob a alegação de que iria roubar alguma coisa (proibição). A reação do garoto de voltar à loja mais tarde no mesmo dia com o dinheiro e comprar o item que estava buscando antes foi feita com o intuito de tornar evidente a ilegalidade da restrição que tinha sido imposta a ele, afinal, era seu direito poder entrar e permanecer na loja sem ser molestado. Em termos narrativos, o sujeito, ao agir, estava reivindicando a permissividade do ato (não-dever-nãofazer).

Quando os discursos referem-se à negação da prescrição, é a modalidade do não-deverfazer que está em jogo. No tópico anterior, um trecho de texto ilustra uma ocorrência textual dessa modalidade narrativa. Na passagem, AV24 mostra como é importante, para a emancipação do jovem de periferia, que ele possa romper com uma espécie de determinismo social vigente (que afirma que os indivíduos que nasceram em famílias pobres devem permanecer empobrecidos, morando em barracos) e morar em casas com melhores condições, evocando uma vitória, ainda que simbólica, sobre tal previsibilidade.

São muitas as ocorrências das modalidades deônticas no corpus, mas antes de thes dedicar mais atenção é pertinente comentar algumas constatações realizadas por estudiosos da juventude quanto a essa mesma categoria. Harkot-de-La-Taille e Bariaud, no artigo já mencionado, verificam que a imagem de adultez de suas jovens entrevistadas encontra-se muito marcada pela perda da alegria, pelo abandono de amigos, de projetos e de prazeres. Nesse sentido, chegam a afirmar que, durante essa etapa, "paulatinamente o dever vai tomando o dia a dia e deixando menos espaço para o querer" (2013, p. 406). Muitas das queixas dos jovens nesses depoimentos dirigem-se às atividades que precisam deixar de fazer (ir a baladas, sair com os amigos) durante a vida adulta. As autoras identificam, no discurso das jovens brasileiras, que o abandono dessas atividades apenas acontece a partir dos 26 anos, quando se tornariam adultas mais "plenas" (p. 415). A tendência geral corresponde, grosso modo, ao senso comum e 
tem algum ponto de convergência com os resultados encontrados pelo já mencionado estudo de Imanishi (2008), dedicado à compreensão da passagem da juventude à vida adulta.

A autora constatou que $23 \%$ dos jovens paulistanos dos dias de hoje entrevistados consideram que "assumir responsabilidades" é o ponto negativo de se tornar adulto (2008, p. 105). Mas, por outro lado, para essa mesma pesquisa do Instituto de Psicologia, o principal aspecto considerado negativo do ingresso nessa fase é "enfrentar a competição do mundo do trabalho" (49\% das respostas, p. 105). Nesse sentido, falando em termos narrativos, talvez seja possível afirmar que não apenas as modalidades do dever-fazer e do não-dever-fazer encontram-se presentes na construção do conceito de adultez desses jovens entrevistados, mas também - e sobretudo - as modalidades atualizantes (poder e saber) e as realizantes (fazer). Um dos maiores medos de se tornar adulto para eles é não conseguir se realizar profissionalmente.

No que tange às respostas dadas à questão sobre o que há de positivo em se tornar adulto, $64,42 \%$ dos jovens disseram que é "tornar-se independente". $15,58 \%$ dos respondentes afirmaram que "constituir uma família" era o melhor aspecto (p. 103). Desse ponto de vista, pode-se considerar que há, aqui novamente, uma forte presença da etapa da competencialização (representada pelo poder-não-fazer, independência), elencada como a parte mais importante de se tornar adulto. Tornar-se independente é especialmente importante para os alunos oriundos de escolas particulares (73,70\%). Os estudantes da rede pública tiveram um alto índice nessa resposta $(52,81 \%)$, mas também viram valor no ato de constituir família $(19,48 \%)$ e de se tornar cidadãos (15,58\%). De modo geral, vê-se que as respostas dos alunos de escolas do governo relacionam-se um pouco mais com funções comunitárias e familiares do que as dos estudantes da rede privada, que, por sua vez, parecem ser mais preocupados com objetivos pessoais.

O roteiro de entrevista do presente estudo não possuía questões especificamente voltadas à depreensão da imagem de adultez dos jovens. Ainda assim, a partir das respostas obtidas, constata-se que eles relatam, sim, um gradativo distanciamento das atividades de lazer para aproximarem-se, cada vez mais, daquelas relacionadas à modalidade do dever no decorrer de seus processos de emancipação. Por outro lado, não necessariamente há atribuição de disforia a essa passagem, como Harkot-de-La-Taille e Bariaud identificaram (2013, p. 406). Talvez os jovens aqui entrevistados já se encontrassem um tanto conformados ou resignados quanto aos deveres que as atividades da vida adulta Ihes exigiam. 
A declaração abaixo, extraída da entrevista de SM28, que conta como foi o processo de escolha de sua profissão, traz um objeto pertinente para a reflexão sobre as modalidades deônticas.

“E: (...) você se considera uma pessoa que faz o que quer?

S: me conside:ro... em partes... porque:... eu gosto muito de trabalhar no terceiro setor... gosto muito de: / de trabalhar com criança e adolescente... GOSto de trabalhar com comunicação que: / que é a formação que eu escolhi justamente... por ter u / um:... um ponto de interrogação... de / de mi / para mim a comunicação é... muito mais alÉM do que:... o forMAL do que o acaDÊmico... mas a comunicação é a que faz as coisas acontecerem ou não né? Então: eu tinha um pouco de dificuldade na minha expresSÃO... e aí comunicação foi... justamente pegar algo que:... eu tinha determinada habiliDAde de relacionamento de / de conVERsa... de... de... agiliZAR de mobiliZAR algumas coisas através da comunicação mas ao mesmo tempo... em várias vezes eu me pegava não conseguindo expressar aquilo que eu de fato:... queria dizer... então... esse NÓ... para mim... estudar comunicação foi um / um jeito de... desamarrar ou de / de... aprofundar isso... mas... hoje eu trabalho em um sisTEma de / de horá:rio de roti:na que ainda não é o que acredito para mim... é:... essa regularidade de... / de... ter que cumprir horá:rio de / de ter que estar num lugar de ter que:... fazer várias coisas do sistema CLT que:... que me: que me deixam um pouco:... intrigada nesse processo (mesmo) de / de... / de pensar se é isso que eu quero para mim..." (Anexo, SM28, p. 16)

A jovem descreve o percurso que a levou a escolher a profissão exercida até a data da entrevista. Uma referência importante feita nesse momento é a figura do talento. Essa noção pode ser compreendida como uma habilidade natural para a realização de uma atividade. Remete, no universo modal, entre outras modalidades, a um saber-fazer. A opção pela profissão de comunicadora vê-se confrontada com uma desvantagem: o "enquadramento" dentro das normas legais (o "sistema CLT"). Em um primeiro momento, esse tipo de regime trabalhista é tomado como algo que restringe excessivamente as ações das pessoas e que, por isso, é malvisto.

A figura do "sistema CLT", ou dos "horários" e da "rotina", para a perspectiva do sujeito parece corresponder a uma prescrição (dever-fazer) vinda do antidestinador. Por outro lado, a mesma figurativização investe também a aquisição das modalidades necessárias à emancipação (em uma última instância, o poder-fazer e o poder-não-fazer), afinal, ela representa a fonte de 
remuneração que permite ao ator do sujeito subsistir. Pode-se dizer que há, aí, uma figura polêmica ("trabalho formal"), que executa dois papéis actanciais (objeto do programa e do antiprograma narrativos), e toma, desse modo, para o sujeito, um valor ambíguo.

Além disso, falando em termos discursivos, é interessante ressaltar que esse envolvimento com a atividade profissional de comunicadora acontece no começo do que virá a ser uma etapa da vida marcada por deveres e compromissos (a adultez). O desenvolvimento da atividade comunicativa, nesse âmbito, desempenha a função de assegurar a continuidade de pelo menos um elemento da infância na vida que se desenvolve posteriormente a esse período, trazendo uma vinculação à modalidade narrativa do querer, naturalmente relacionada à mentalidade das crianças.

O encontro com o fechamento de possibilidades causado pelo regime empregatício significa, no nível narrativo, um questionamento da crença do sujeito no objeto. Fontanille e Zilberberg articulam os termos dessa categoria em quatro posições: "afirmar", "duvidar", "negar" e "crer" (2001, p. 265). Segundo a classificação dos autores, pode-se considerar que o sujeito investido por "SM28" teria passado da fase do "duvidar" (ceticismo), chegando ao que se denomina "negar" (niilismo). Mesmo tendo sido quase invalidadas pelo discurso, as vantagens do contrato profissional, contudo, não haviam sido descartadas, em um nível pragmático, até o momento da entrevista, o que significa que há, no trecho, pelo menos algum indício da presença da categoria narrativa do "crer".

Quanto ao nível discursivo, na temporalidade anterior ao narrado, há uma passagem na qual a jovem diz que a comunicação é sentida como um jeito de desatar um nó. Nesse momento, ela aproxima-se de uma figura que já tinha sido observada durante o estudo da palavra liberdade ("Introdução" da presente dissertação). A facilidade natural e durativa para esse ofício que declara possuir está ligada a uma dificuldade que a entrevistada tinha na infância. A superação desse obstáculo é, para ela, uma espécie de projeto para o futuro, feito em nome de seu talento.

A incomunicabilidade, sob a perspectiva modal, remete a uma impotência. No texto em questão é a incapacidade de se expressar que está em jogo. Isso aparece por meio da frase "várias vezes eu me pegava não conseguindo expressar aquilo que eu de fato:... queria dizer"(Anexo, SM28, p. 16). A dificuldade na comunicação talvez remeta igualmente a uma carência mais ampla que a mera incompetência (não-saber-fazer). Aquilo que não se conhece (não-saber-ser) tampouco pode ser expresso.

Tudo leva a crer que há, nesse caso, um sujeito virtualizado mas disjunto dos valores atuais (poder e saber). A profissão de comunicadora representa discursivamente o objeto de 
valor com o qual o sujeito espera entrar em conjunção. A questão levantada pelas reflexões sobre esse trecho de texto remete a uma problemática comum à maioria dos jovens entrevistados por Imanishi, a incerteza quanto ao futuro profissional (2008, p. 105).

\subsubsection{Localizando figuras e temas da competencialização}

Já tendo sido examinadas algumas das ocorrências dos valores poder-fazer e saber-fazer no corpus (em suas confrontações com as categorias do querer e do dever), vale a pena também lançar um olhar individualizado a elas neste tópico, dedicado especialmente à etapa da competencialização. A depreensão dos temas e figuras relacionados às modalidades atuais dá uma visão mais geral do universo discursivo que as circunda, nos textos analisados. Com esse objetivo em mente, a tabela abaixo sistematiza os principais elementos figurativos e temáticos encontrados na fala dos entrevistados, classificando-os nas duas categorias. Diferentemente do que aconteceu nos quadros 1 e 3 deste estudo, no presente momento as variações decorrentes da aplicação de cada uma das modalidades nas quatro posições do quadrado semiótico não são discriminadas, com vistas à obtenção de uma abordagem mais dinâmica.

\begin{tabular}{|c|c|c|}
\hline Modalidade & Temas & Figuras \\
\hline \multirow[t]{4}{*}{ Saber-fazer } & Formação & $\begin{array}{l}\text { Universidade } \\
\text { Vestibular } \\
\text { Escola } \\
\text { Evasão escolar }\end{array}$ \\
\hline & Viagem & $\begin{array}{l}\text { Autoconhecimento } \\
\text { Cidades (pequena, grande) } \\
\text { Viagens pelo país }\end{array}$ \\
\hline & Conhecimento & $\begin{array}{l}\text { Identidade racial } \\
\text { Redes sociais } \\
\text { Convívio com pessoas mais velhas }\end{array}$ \\
\hline & Relacionamentos & $\begin{array}{l}\text { Redes sociais } \\
\text { Transformação social } \\
\text { Convívio com pessoas mais velhas }\end{array}$ \\
\hline
\end{tabular}




\begin{tabular}{|c|c|c|}
\hline \multirow[t]{6}{*}{ Poder-fazer } & Trabalho & $\begin{array}{l}\text { Transformação social } \\
\text { Ser referência a outros jovens } \\
\text { Escolher a carreira, cursos } \\
\text { Trabalhar em ONG's, instituições, empresas, com } \\
\text { cultura } \\
\text { Assistencialismo }\end{array}$ \\
\hline & Lazer & $\begin{array}{l}\text { Viajar } \\
\text { Ir para a balada }\end{array}$ \\
\hline & Realização pessoal & $\begin{array}{l}\text { Transformação social } \\
\text { Ser referência a outros jovens }\end{array}$ \\
\hline & Escolhas & Escolher a carreira, cursos \\
\hline & Relacionamentos & $\begin{array}{l}\text { Transitar por vários bairros, grupos, comunidades } \\
\text { Redes sociais }\end{array}$ \\
\hline & Violência & $\begin{array}{l}\text { Preconceito racial } \\
\text { Distúrbios mentais } \\
\text { Violência policial } \\
\text { Abuso sexual } \\
\text { Violência doméstica } \\
\text { Passar fome }\end{array}$ \\
\hline
\end{tabular}

Quadro 5-Panorama de temas e figuras, poder e saber

No que tange à modalidade do poder, numerosas figuras remetem a articulações disfóricas, por vezes relacionadas à impotência. Isso se dá seja pelo não-poder-fazer (discriminação racial, distúrbios mentais, passar fome) ou pelo não-poder-não-fazer (violência policial, abuso sexual, violência doméstica). As figuras remetem à variedade de riscos sociais aos quais os jovens veem-se expostos em seus cotidianos. A sistematização desse quadro mostra algumas das razões pelas quais pode-se considerar que os jovens negros no Brasil de hoje são um segmento vulnerável e que precisa ser cuidado pelas autoridades.

Como figuras eufóricas das categorias do poder, encontram-se transformação social e ser referência a outros jovens (ambas relacionadas à liberdade). Além dessas figuras, há também menção aos relacionamentos pessoais e à capacidade de trânsito em níveis variados (entre grupos sociais, localidades, bairros, etc.), vinculadas ao mesmo valor modal. A independência se vê representada pela possibilidade de escolha, que também se dá em vários campos semânticos tais como profissão e carreira universitária, por exemplo.

Quando são observados os resultados obtidos no âmbito da modalidade do saber-fazer, nota-se uma presença expressiva de temas e figuras relacionadas à formação e à educação. 
Nesse sentido, há uma associação entre a modalidade e o ensino institucionalizado, aquele que acontece dentro das escolas e universidades. Por outro lado, há também, como se verá adiante, menção a aprendizados de outras ordens, tais como o realizado a partir da convivência com pessoas experientes ou os que se dão durante as viagens (turísticas ou a trabalho).

Dos quatro jovens entrevistados, apenas CS20 não havia cursado faculdade até o momento do depoimento. SM28 mostra-se especialmente contente com seu diploma universitário. Os estudos constituem um papel importante em sua emancipação, pois representam a capacitação que possibilitou-Ihe exercer a profissão de comunicadora social. Além disso, também foi na escola que conheceu uma professora que, até o momento da narração, servia-lhe como fonte de inspiração. AV24 e JS23 ainda não haviam concluído os estudos superiores até a data da entrevista. O segundo deles ressalta a importância que estar podendo cursar uma faculdade tem para ele, tendo vindo de uma família que não pôde lhe oferecer muito auxílio para o ingresso na instituição e nem para a sua manutenção dentro dela (como abordado no tópico "Manipulação").

Indo além da abertura de possibilidades que a universidade e a escola representam para o universo da formação desses jovens, os espaços que ocupam e visitam são igualmente elementos-chave para seu crescimento profissional e para a consecução dos seus objetivos de vida. Quanto a esse mesmo tema, verifica-se uma convergência entre os elementos espaciais discursivos e os processos de aquisição de saber do nível narrativo. AV24 menciona as viagens a Brasília, no âmbito da "Conferência da Igualdade Racial" e da "Conferência Nacional de Cultura" nas quais esteve presente; CS20 fala do campeonato de música ao qual foi, junto com seus companheiros de banda; JS23 argumenta que é imprescindível que os jovens saiam da zona de conforto para adquirir uma visão mais ampla de mundo.

\footnotetext{
“é... eu acho que as pessoas têm que querer buscar esse tipo de capacidade de transitar... uhn: não falo transitar assim para mil luGAres mas: vamos sair um pouquinho do / do mundo estático... que nem eu te / eu te falei muito do lance de comunidade de jovens não vim / não sair tanto da comunidade para sair para o centro... essa não ida... do jovem para o centro... impede que o jovem coNHEça... milhões de coisas" (Anexo, JS23, p. 13, grifos nossos)
}

Criando uma oposição entre duas espacialidades (uma mais próxima e outra mais distante do ator do narrado), os bairros periféricos e o centro da cidade são vistos pelo 
entrevistado como duas localidades que precisam ser conhecidas e visitadas para que o jovem dos subúrbios, de fato, entre em contato com referências variadas de mundo. Aquele indivíduo que vive na "zona de conforto", espaço designado pelo narrador para representar uma conformação e uma estagnação durativas, não conheceria a realidade de uma maneira mais ampla.

SM28, por sua vez, também realizando um movimento que associa deslocamentos espaciais a aquisição de saber, menciona a sua saída de uma cidade pequena, indo à São Paulo, pois viver lá era algo que a impedia de entrar em contato com a diversidade cultural. Conta também que apenas quando deixou a localidade, no âmbito das viagens de trabalho com protagonismo juvenil, é que pôde "ver outras referências", "conhecer outras pessoas e (...) despertar para várias outras: coisas" (Anexo, SM28, p. 18). Um pouco adiante na entrevista, a entrevistada dá destaque aos estudos universitários, dentre as possibilidades que teve na vida (figura que representa, em seu discurso, o valor de saber-fazer). Em um momento, diz que "sei que eu sou uma privilegiada... enquanto mulher negra de ter acesso à universiDAde" (Anexo, SM28, p. 18). Em seguida, associa o ato de estudar a seu fortalecimento pessoal. No nível narrativo, o destinador que auxilia o sujeito ("SM28") a buscar independência está investido por um ator coletivo ("duas professoras" e "mãe"). Essa figurativização remete a uma valorização do estudo formal, pois duas das personagens que compõem o ator desse actante são profissionais ligadas à escola e a outra identifica na educação um valor essencial para os indivíduos ("mãe").

Além da escolaridade formal, o saber intuitivo e o processo de conhecimento de si são lembrados como partes importantes do processo de emancipação de SM28. Isso verifica-se quando ela diz que sente precisar de mais amadurecimento para o reconhecimento das próprias vontades (Anexo, SM28, p. 19). Os modos de apreensão presentes no relato de SM28 não se relacionam exclusivamente com a modalidade do saber porque têm um aspecto sensível. Nesse sentido, também dizem respeito à etapa da potencialização, pois variam em graus de crença no objeto e confiança no sujeito, procedimento necessário para a assunção do querer. Greimas, em seu artigo "O saber e o crer: um único universo cognitivo" (2014, pp. 127 -145), fala da permeabilidade dos sistemas de conhecimento diante dos sistemas de crenças e termina por se conformar com a afirmação de Jean-Pierre Vernant de que "há distintos tipos de racionalidade, antes de afirmar que a razão exclui a fé" (p. 138). Desse modo, não apenas o saber, mas o elemento cognitivo em seu sentido mais amplo (que comporta o crer, o saber e o conhecer) precisa ser levado em consideração no estudo da emancipação dos sujeitos. 
Além da importância da educação universitária, da necessidade das viagens e dos modos de apreensão da autoconsciência no processo de busca dos indivíduos pelos próprios contornos (identidade) e objetivos (ambições), as inovações tecnológicas do século XXI também se encontram entre as figuras que investem a modalidade do saber no corpus. As redes sociais e as mudanças no âmbito das possibilidades comunicacionais e na circulação das informações trouxeram alterações significativas à experiência de vida das pessoas. SM28 menciona o fato de que os jovens adquiriram a capacidade de ser difusores de informação, de ser "contadores de várias histórias" e que adquiriram o poder de "mostrar outras versões" dos fatos (Anexo, p. 20). Corroborando essa afirmação, pode-se dizer que a popularização dos aparelhos informatizados culminou em uma nova forma de transmissão de conhecimento e comunicação, estando mais à disposição dos indivíduos, por exemplo, os vastos alcances das mensagens "em cadeia", com sua capacidade aumentada de reprodução e disseminação.

Andrade e Mussi (2008) destacam que "A explosão de informações e das comunicações mundiais dispara processos de misturas e combinações entre modos de vida, com base no alto e rápido fluxo de bens simbólicos e produtos por todos os lugares-relações do planeta" (p. 27). Desse fenômeno, ressalta-se o que as autoras chamam de descontinuidade das tradições, dada à dificuldade no estabelecimento de identidades nesses tempos. As autoras ainda complementam essa ideia, dizendo que "na atualidade, múltiplas referências podem coabitar uma única vida, exigindo uma determinação colossal dos indivíduos para o empenho em ideiasprojetos no decorrer da ida" (p. 27).

Como um contraponto às considerações das autoras mencionadas, é importante ressaltar o enorme potencial unificador que essas múltiplas possibilidades de conexão, representadas pelas novas tecnologias, possuem, quando engajadas em um sentido único. Um exemplo disso foi a organização que culminou no movimento massivo de manifestações de rua que ocorreram nos anos 2013 e 2014, pouco antes da celebração da Copa Mundial de Futebol no Brasil, cuja origem foi o protesto contra a elevação da tarifa de transporte urbano na cidade de São Paulo, mas que se disseminou por todo o país. Os manifestantes, em sua maioria, eram jovens, talvez um reflexo da sua aptidão diante das novas tecnologias, pois uma parte considerável da organização e da logística das atividades foi feita via internet.

A nova configuração dos atos comunicativos, possibilitada pelo aparecimento das redes sociais entre outras novidades tecnológicas, traz uma maior facilidade à interação entre os indivíduos, fazendo, entre outras coisas, com que o saber das notícias aconteça sem necessariamente passar pelos grandes veículos de mídia ou por suas estratégias enunciativas (e 
manipulativas). As mensagens dos novos dispositivos (como o Facebook) são normalmente de cunho mais individual do que aquelas dos meios de comunicação de massa, haja vista que, a princípio, são produzidas em âmbito pessoal e não profissionalmente (muito embora haja exceções a isso). A circulação de informação, hoje, tem mais capilaridade e é menos centralizada por agências de comunicação do que há algumas décadas. As principais dificuldades atuais nesse processo parecem residir no âmbito da credibilidade das informações obtidas, ao passo que as possibilidades de contato com textos variados cresceram exponencialmente e que qualquer um (com acesso) pode postar as suas ideias no meio virtual.

\subsubsection{Síntese do tópico}

A partir do que foi estudado nesta seção ("3.2.2 Modalizações do fazer"), constatou-se que, nesse assunto, o corpus faz menção a temas que cativam mais a disposição do sujeito (tais como transformação, formação, trabalho e relacionamentos) e a outros, que são usualmente recusados por ele (trabalho - novamente, tristeza e violência). O querer-fazer e o não-poderfazer estabelecem, quando vistos sob o quadro das homologações modais, uma relação de contrariedade bastante presente no corpus, cujos investimento discursivo e articulação tensiva variam de caso a caso. De modo geral, a incompatibilidade dessa relação acarreta a transferência de carga fórica aos programas narrativos subsequentes do sujeito, imprimindo tonicidade à sua ação.

No que tange às modalidades deônticas, verifica-se uma forte presença da figura transformação social. Trata-se de atividade que a maioria dos entrevistados declara realizar. Já a sanção sobre o fazer, por sua vez, em especial nos programas que estão investidos discursivamente com a figura mencionada acima, parece gerar uma carga fórica que se transmite a PNs subsequentes. Essa "valência afetiva" pode ser descrita figurativamente por algo como a autoconfiança e serve como estímulo para que o ator discursivo mantenha em andamento as suas atividades. As profissões relatadas no âmbito das entrevistas têm em comum o fato de possuírem contato diário com a possibilidade de alteração da realidade social e das comunidades nas quais os entrevistados habitam.

Do ponto de vista da etapa da competencialização, no corpus constata-se que a modalidade do saber desempenha um papel-chave. A discursivização dessa categoria dá-se por meio de figuras como as instituições formais de ensino (a universidade, a escola), assim como 
pelos temas das viagens e deslocamentos espaciais, ou ainda pelas indagações das buscas por autoconhecimento.

A associação da temática da identidade com a modalidade do saber é especialmente significativa nos discursos das entrevistas. Talvez essa proximidade se deva ao acentuado valor de descontinuidade que afeta as pessoas na contemporaneidade, que desconstrói muitas das identidades que eram tradicionalmente mais estáveis. Ele é promovido pela aceleração dos processos comunicativos da contemporaneidade e pelo acréscimo de complexidade no âmbito dos relacionamentos, sejam eles pessoais ou profissionais. Tal "cenário" social descreve o contexto no qual os jovens de hoje crescem e tornam-se adultos, de modo que a importância dada às habilidades relacionadas à modalidade do saber parece advir da capacidade desta de organizar e trazer sentido para o que parece desconexo. Essa questão será aprofundada no capítulo seguinte, "Comentários tensivos e extratextuais". 


\section{Comentários tensivos e extratextuais}

Tendo sido examinadas as configurações fiduciárias, discursivas e narrativas nas entrevistas do corpus (esta última subdividida em manipulação e em modalizações do ser e fazer), este derradeiro momento busca trazer alguma complementação às observações já realizadas. Como início desta etapa, na qual análise e síntese são combinadas para a depreensão das perspectivas de emancipação presentes no corpus, estudam-se alguns dos pontos mais conflituosos dos depoimentos. Para tanto, faz-se pertinente recorrer ao instrumental teórico da semiótica tensiva. Ele é especialmente útil na descrição de tais passagens, por sua capacidade de explicar as variações que ocorrem nas dimensões da intensidade e da extensidade dos discursos, assim como nas suas subdimensões (respectivamente, andamento e tonicidade, e temporalidade e espacialidade), segundo a formulação dada por Zilberberg (2011, p. 250).

A dinâmica dessas grandezas permeia os demais níveis de sentido reconhecidos pela ciência da significação, manifestando-se por meio do que se denomina valor do valor, ou valência. Fontanille e Zilberberg afirmam que as valências "definem-se (...) por sua participação numa correlação de gradientes, orientados em função de sua tonicidade sensível/perceptiva" (2001, p. 20). Graças ao instrumental tensivo, hoje é possível depreender analiticamente alguns desses fenômenos de natureza sensível. Um outro conceito vindo do mesmo nível semiótico, o acontecimento, é também de especial utilidade para o tratamento das problemáticas tratadas neste capítulo (Zilberberg, 2011).

Após o tópico inicial, ainda utilizando critérios tensivos, efetuam-se comentários sobre o ingresso dos jovens nos cursos superiores, haja vista esse ter sido um tema bastante mencionado nas entrevistas. Simultaneamente, um esforço é realizado para o estabelecimento de pontos de convergência entre os estudos semióticos e as demais ciências humanas. Tal percurso é realizado com o objetivo de se chegar a uma compreensão que relacione, ainda que superficialmente, as características da juventude brasileira da atualidade, em seu anseio por formação, e os fenômenos semióticos constatados a partir das análises desta dissertação. 


\subsection{Algumas considerações tensivas}

Para a compreensão das passagens do corpus que tratam de conflitos marcados, a noção de acontecimento é fundamental. Tal conceito designa a combinação das grandezas tônicas e aceleradas, no eixo da intensidade, e breves e fechadas, naquele da extensidade, entre outras características (Zilberberg, 2011, pp. 235-236). Além disso, nesse momento, os instrumentais teóricos representados pelas quantificações subjetivas ( $p p .55-60$ ) e pelo esquema de presença (Lopes e Tatit, 2008, p. 86) são também de valia, por fornecerem mais operacionalidade às análises, cada qual em sua abordagem. No primeiro item da seção, "4.1.1 Experiências tônicas e disfóricas", trata-se de três episódios narrados nas entrevistas que trazem passagens de naturezas distintas. A abordagem discursiva, nesse momento, transita pelos temas violência (nos âmbitos escolar e social) e abuso (sexual e de autoridade).

A segunda parte do tópico, ainda sobre temas relacionados ao nível tensivo, dedica-se à discussão postulada por Harkot-de-La-Taille (2011), que identifica no discurso social e acadêmico a ideia de que a juventude seria apenas um período de transição, átono, entre a infância e a adultez. Suas considerações fundamentam-se nas reflexões sobre identidade feitas por Paul Ricœur (2004). Além disso, as autoras identificam, nas estruturas discursivas do "não mais" e do "ainda não" (postuladas inicialmente por Sartre, em L'Être et le Néant, 1943) a criação de justificativas para a subestimação da juventude dentre as demais etapas da vida.

Ao final da seção, alguns eventos que podem ser classificados como tônicos e eufóricos, do ponto de vista subjetivo, são evocados, como contraponto aos acontecimentos disfóricos, para uma compreensão mais apurada do que eles representam para a emancipação dos jovens entrevistados.

\subsubsection{Experiências tônicas e disfóricas}

Além do conceito de acontecimento, a análise aqui feita vale-se dos conceitos de categorias modais volitivas (do nível narrativo) e de algumas figuras disfóricas (depreendidas no capítulo 2, "Discursividade da emancipação nas entrevistas"). A ideia é relacionar o funcionamento dos elementos encontrados nesses três diferentes níveis da significação, a partir dos extratos do corpus. 
Verifica-se, algumas vezes nas entrevistas, que a categoria modal indisposição (nãoquerer-fazer) vem precedida de experiências tônicas, aceleradas e disfóricas do ponto de vista do sujeito. É como se essa categoria, ao constituir-se próxima a um acontecimento, fosse influenciada pelo arrebatamento afetivo que atinge o sujeito após um evento inesperado. 0 "assombro" pode ser atribuído ao rol de causas pelas quais o querer-fazer torna-se não-quererfazer. Como um primeiro exemplo para ilustrar o fenômeno referido, utiliza-se aqui o relato de CS20, que narra, no momento destacado, a razão pela qual se viu obrigada a abandonar os estudos.

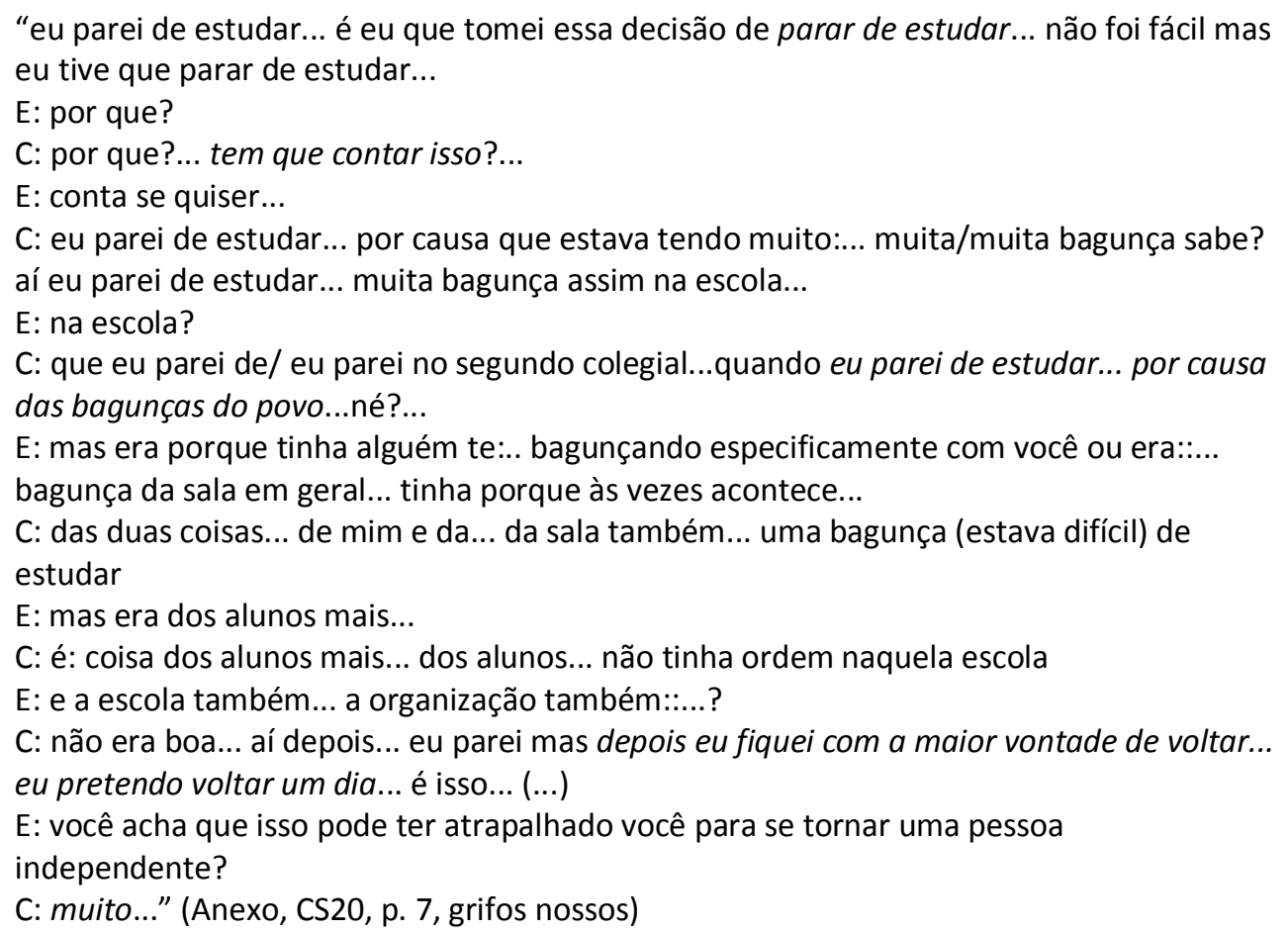

Logo à primeira vista, salta aos olhos a indisposição inicial da entrevistada de expor as razões que a fizeram deixar de estudar (expressa pela pergunta "tem que contar isso?"). Talvez por ser um tema difícil para ela, como se a encenação discursiva trouxesse de volta a dor da experiência, em um primeiro momento, CS20 mostra-se reticente quanto a falar. Em seguida, convence-se de prosseguir e relata uma experiência sofrida no ambiente da escola, a qual constitui o marco de interrupção de seus estudos: um assédio no âmbito da instituição de ensino; bullying por conta de uma característica física sua, mencionado em outro trecho da entrevista. Conforme relata, sua saída foi uma resposta à "bagunça" e às agressões morais que sofria.

Do ponto de vista tensivo, há, nessa passagem, um acúmulo de tonicidade, que atinge um teor exagerado para o sujeito. Para ter condições de lidar com esse excesso, ele precisa, de 
algum modo, aumentar a sua presença na dimensão da extensidade. Esse acréscimo ocorre nas suas duas subdimensões, a temporalidade e a espacialidade, e é figurativizado pelo período que CS20 passa longe da instituição. Pouco a pouco, após o arrefecimento da intensidade do acontecimento, a sensação que começa a aflorar novamente no sujeito, é a vontade de voltar a estudar (querer-fazer, no nível narrativo).

Da perspectiva da discursividade (e mais especificamente da temporalização), vê-se que a vivência dolorosa encontra-se relatada majoritariamente no tempo do narrado, e que a recuperação é contada na temporalidade da narração. Esse último sistema temporal é preenchido por relatos eufóricos muitas vezes no corpus. É como se o tempo da narração trouxesse consigo um tom otimista à voz dos narradores. Quando utilizam as temporalidades do narrado, por outro lado, aqueles que contam suas histórias parecem sentir-se mais à vontade para relatar as experiências disfóricas, mesmo que sejam agudas. Talvez essa tendência se deva à dificuldade do reconhecimento das questões difíceis que envolvem uma problemática enquanto ela ainda está em curso. Segundo essa hipótese, os tempos do narrado seriam os "momentos" do discurso mais apropriados para a observação e encenação das experiências tônicas, aceleradas e disfóricas vividas, pelo menos no que tange aos discursos de caráter autobiográfico.

Voltando ao trecho transcrito acima, vê-se que há, como mencionado, no nível narrativo, uma transformação de estados modais, o querer torna-se não-querer-fazer (indisposição). Tal mudança é motivada pela ação do antissujeito ("bagunça de seus colegas" e "desorganização da escola") e, adiante no depoimento, com o aprofundamento do conflito, verifica-se que o sujeito entra em conjunção com o valor de querer-não-fazer (abulia). Por fim, com o reconhecimento do sentimento negativo, ele vincula-se ao não-querer-não-fazer, investido discursivamente pelo término da necessidade do ator "CS20" de estar afastado da escola.

Para que se compreendam melhor os efeitos sociais que a saída das instituições educativas tem sobre a vida dos indivíduos, é pertinente citar Imanishi que, relendo Hannah Arendt, considera esse espaço uma instância de mediação entre as esferas pública e privada da sociedade, denominando-o, assim, um “âmbito pré-público" (2008, p. 34). Sua função seria a de introduzir a criança nas atividades sociais do mundo. $O$ impedimento de estudar - pode-se supor a partir disso - dificultaria a inserção dos indivíduos nessa esfera da vida. O abandono das instituições de ensino por parte dos alunos incorre, possivelmente, em consequências do ponto de vista da sua interação com o mundo. Tal ocorrência (a evasão escolar), no Brasil, ainda é representada por um índice elevado. Segundo a reportagem "Brasil tem 3a maior taxa de evasão escolar entre 100 países, diz Pnud", publicada no UOL em 2013, o Brasil contava com um índice 
de $24,3 \%$ de evasão escolar em 2012 (um a cada quatro alunos). A entrevistada CS20 reconhece o caráter prejudicial do abandono dos estudos ao final do trecho transcrito acima, quando volta a dar importância a esse tipo de oportunidade.

Adiante no depoimento, a entrevistada também conta que o envolvimento que teve com a música funcionou como um "divisor de águas" em sua vida, trazendo de novo a felicidade e a disposição a seu cotidiano em áreas que não eram as das práticas culturais, como o trabalho ou os relacionamentos pessoais. A atuação junto à banda é relatada com tonicidade e euforia pelo discurso da jovem. Além disso, pode-se afirmar que o vínculo da entrevistada com a musicalidade, no nível narrativo, constitui um marco no processo da transformação de estados modais, assim como o acontecimento disfórico, já mencionado acima.

A partir da observação desse caso, verificou-se que as experiências tônicas e disfóricas vividas pelo sujeito exigem uma resposta tensiva específica (que se dá no eixo da extensidade), para que possam ser "assimiladas". As sensações de tonicidade e aceleração exageradas fazem com que seja necessária a atenuação - a retirada do excesso de mais, daquilo que é provado pelo sujeito, por meio de "compensações" em temporalidade e espacialidade (Zilberberg, 2011, p. 60).

Além disso, muitas das passagens marcantes e difíceis da juventude encontradas nos depoimentos são caracterizadas, no nível narrativo, por descontinuidades que representam rupturas no estado de conjunção do sujeito com o objeto (a parada da continuação, segundo Lopes e Tatit, p. 86). O mecanismo de alongamento em extensidade observado coincide, em alguns dos casos aqui estudados, com a continuação da parada, ou o aprofundamento da separação entre sujeito e objeto.

Com o objetivo de exemplificar melhor esse fenômeno teórico, indo a outro exemplo do corpus, vê-se que AV24 também relata uma passagem na qual se identifica tonicidade e disforia, que pode ser caracterizada como acontecimento. Dessa vez, trata-se de tema familiar e não mais de um assunto do campo da vida escolar (esfera pré-pública), como visto acima. 0 entrevistado conta que um de seus irmãos foi morto, vítima de confronto com a Polícia Militar e que esse evento provocou-Ihe um sentimento de dor acentuada. Em resposta a isso, mudouse de casa para morar por um tempo com amigos e depois com a sua namorada. A necessidade de habitar em outro local foi a solução encontrada por ele para não precisar mais viver em meio às constantes reminiscências que Ihe vinham ao residir no mesmo lugar no qual o irmão tinha vivido. Tendo sua mãe ficado também severamente abalada pelo ocorrido e mudado de cidade, o entrevistado conta que teve que se reestruturar por si mesmo. Enquanto elaborava emocionalmente o falecimento, deixou o lar familiar. 
“meu irmão faleceu né?... vítima::... de um confronto com a polícia militar... e aí ele... é::... a polícia matou ele... e::... e eu não queria voltar para essa minha casa que eu estava morando que ele morava entendeu? porque tudo lemBRAva... tinha uma... aí eu fiquei morando na casa de amigos um tempo... fiquei morando na casa de amigos um tempo... e aí depois a gente alugou a casa que a gente está morando até hoje assim então..." (Anexo, AV24, p. 1, grifos nossos)

O não-querer-fazer encontra-se investido, entre outras figuras, pela perda de vontade do ator do sujeito de viver na casa na qual habitava. A passagem do estado inicial (querer-fazer) a essa disposição modal, ocorre, mais uma vez, acompanhada pelo que se denomina acontecimento. Bastante estudado pela semiótica atual, esse fenômeno pressupõe a celeridade e "a saturação da tonicidade que significa para o sujeito uma tempestade modal que vê o sofrer suplantar o agir" (Zilberberg, 2011, p. 235). Diante da sua intensidade, o sujeito acaba tendo que interromper o fluxo da narrativa, arrebatado pelo impacto do encontro inesperado.

Para explicar melhor a natureza do acontecimento, Zilberberg distingue duas formas do que denomina eventualidade: o golpe e a vez (pp. 52-53). Exemplificando a conceituação por meio da análise dos termos que designam o ato de beber na língua francesa, o autor distingue lampée (talagada, em português), que é "um grande gole de líquido sorvido de uma só vez" (estilo intensivo), do beber "pouco a pouco, em pequenos goles" (estilo extensivo). O primeiro encontra-se ligado ao acontecimento, mais impactante do que o segundo.

Além de tônico ("bebido em uma talagada"), o falecimento do irmão de AV24 (decorrente de um confronto com a polícia) é inesperado. Disso, decorre o fato de que ele, tal como postula Valéry (citado por Tatit, 2010, p. 121), leva pouco tempo para penetrar no sujeito. A resposta ao acontecimento, por sua vez, é lenta, ao contrário da que se dá ao evento esperado. Isso explica a incapacidade momentânea do entrevistado de "habitar" a sua própria consciência após a morte do familiar.

Corroborando a tese de que há, nessa passagem, uma concomitância do acontecimento com o que se denomina continuação da parada, é interessante observar que o mesmo autor pauta o cadastro modal do fazer remissivo (cessar) com base no que denomina modalidades factivas e páticas, subdividindo-as em registros cognitivos e pragmáticos (2006, p. 139). Com isso, pode-se dizer que descreve com precisão o quadro do sujeito que está agora em questão, pois o ator "AV24" desconsidera (ignora) as coisas que acontecem a seu redor em virtude do espanto que sentiu, apenas podendo cumprir com as obrigações do momento (dever).

A mesma passagem significa também uma ênfase nas categorias do ser. Como já visto, essas dizem respeito à existência modal do sujeito (Greimas, 2014, pp. 106 - 107). Os programas 
de fazer relatados no trecho acima ("ir morar na casa de amigos", "alugar uma casa para morar com a namorada") não correspondem ao foco principal do desenvolvimento narrativo. Tampouco significam alterações relevantes do ponto de vista da sobremodalização potencial (crer-ser) do sujeito. No que tange ao quadrado da agitação, há aí uma oscilação entre o medo e a inquietação. Trata-se de programas de uso, haja vista que o programa de base (mais amplo), por sua vez, está cuidando de recuperar o contrato fiduciário do sujeito com o destinador, para que o fazer possa ser retomado. 0 restabelecimento da progressividade desse último programa é o único modo de fazer com que o querer-fazer de base, essencial ao agir no mundo, volte a ser ativado.

De certo modo, o sujeito também está, nessa passagem, sob a influência de um deverfazer (prescrição). As condições para a continuidade do fluxo do fazer lhe foram transferidas por um destinador transcendente (Tatit, 2010, p. 30) e reflexivo, que o impediu de estagnar e de se entregar completamente aos sentimentos que vigoravam no momento do acontecimento. Um pouco adiante na entrevista, o jovem descreve como foi o processo de arrefecimento do impacto da experiência traumática.

"então foi um momento meio complicado assim da gente poder se::... de ligar no que a gente estava fazendo e::... e aí eu fiquei moran/ eu fiquei morando na casa de amigos um tempo entendeu?... depois a gente alugou essa casa que a gente está morando aqui agora... e::... então acho que eu estou sentindo ainda esse::... esse gosto... tou sentindo ainda esse::... como que é conviver com essa/ como que é viver entendeu?... nesse lance da independência... mas de uma maneira que a gente não queria ter vivido mas teve que conviver entendeu?..." (Anexo, AV24, p. 2, grifos nossos)

A frase inicial do trecho selecionado remete ao já mencionado arrebatamento do sujeito, que o impediu de realizar ações conscientes nesse período. A incapacidade de "se ligar nas coisas que vinha fazendo" demonstra que o ator do sujeito ainda estava comprometido emocionalmente com o acontecimento (em conjunção temporal e disjunção espacial com ele), vivendo os efeitos de sua elevada intensidade. Já utilizando estruturas linguísticas mais próximas da temporalidade da narração, o entrevistado relata que começa a poder sentir "como é" viver uma vida independente. Isso revela que, aos poucos, o sujeito pôde elaborar a tonicidade e a celeridade do acontecimento e sensibilizar-se novamente para responder a ele. A partir de então, as figuras da saída da casa dos pais e do início de sua vida independente ao lado da namorada começam a ser mais "provadas" do ponto de vista subjetivo. 
Outro relato do corpus traz também uma passagem que remete à tonicidade e à disforia no discurso. Nele, SM28 narra um episódio de abuso sexual cometido contra ela durante a infância. O trecho em questão apresenta uma disposição modal complexa, na qual combinamse o não-querer-fazer, o não-saber-fazer e o não-poder-não-fazer. Após esse primeiro momento discursivo ("o ato de violação"), há uma transição do não-querer-fazer para o querer-não-fazer, como se vê com mais detalhe adiante.

"quando eu era criANça... foi uma vez... que eu fui no piquenique do corAL... e:.... e aí tinha um cara que estava ensinando a nadar... e eu era louca para aprender a nadar... 'ah me ensina me ensina' teve uma hora que ele me levou para o fundo da pisCIna... e aí ele tenTOU / tentou me agarrar assim... eu lembro que eu não gritei... que eu n / que eu fiquei: tipo: catatônica com aquilo mas aí eu me segurei na beirada da piscina e fui / fui / fui: até... / fui num lugar que dava pé assim... isso reverberou em / em várias outras / várias... primeiro que eu: nunca mais quis nadar... né? eu lembro que eu contei para a minha mãe... mas também não entendia muito o que tinha acontecido e a minha mãe ficou:... super-revoltada mas... também eu acho que a gente não foi atrás... da pessoa... e aí ((clique com as mãos)) isso teve meio que um apagão assim... eu esqueci... e aí eu fui lembrar aGOra tipo... pensando né meu 'eu sou louca para aprender a nadar mas porque que eu não fui resolver isso? de: aprenDER a nadar de procurar'... e aí eu lembrei dessa situação que foi uma situaÇÃO... quando eu tinha sei lá nove dez Anos... e que: / que trouxe né? que / que / esse tipo de violência marcou de um jeito que veio para... até hoje assim..." (Anexo, SM28, p. 17, grifos nossos)

A intensidade daquilo que ocorreu e marcou significativamente a experiência do ator "SM28" ressalta-se na frase "eu fiquei tipo: catatônica com aquilo". Como a ação do abusador foi inesperada para ele, a resposta à invasão não pôde ser rápida, como se vê na fala "eu não gritei". De certo modo, há que se considerar o fato de que esse ator que investe o sujeito ("SM28") era criança no momento do episódio, o que também traz a questão de que não podia "entender" (não-saber-ser) completamente quais eram as intenções do agressor. Trata-se de uma passagem complexa do ponto de vista das paixões. A análise do nível modal permite identificar alguns elementos importantes quanto à distribuição de intenções presentes no trecho, como se verá adiante. O percurso modal do sujeito inicia-se na posição do querer-fazer, passando por todas as posições previstas no quadrado semiótico e chegando, por fim, a um retorno à posição do começo. 0 esquema a seguir visa a trazer mais clareza a essa trajetória. 


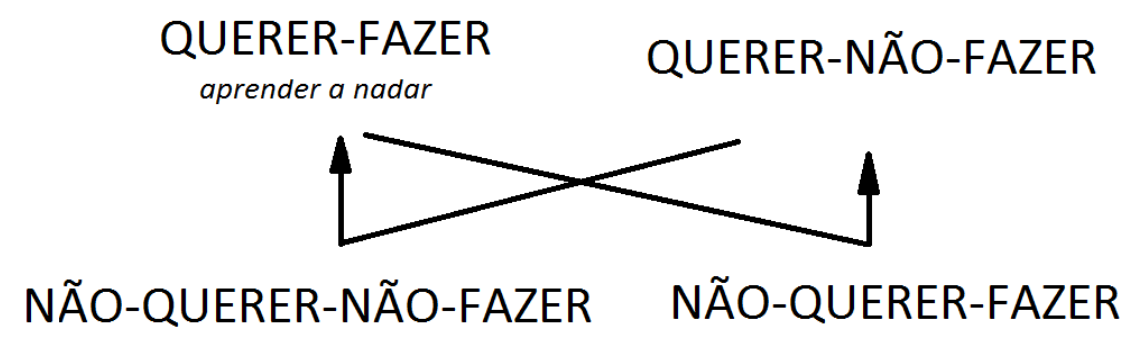

Figura 12 - transformações volitivas a partir de abuso sexual

Estando o sujeito, em um primeiro momento, em conjunção com o valor da disposição ("querer-fazer", investido, por sua vez, pela figura "aprender a nadar"), a partir do contato com a experiência disfórica ("abuso sexual"), ele indispõe-se a agir. Com o aprofundamento dessa configuração modal, ele entra em conjunção com o querer-não-fazer, abulia, valor discursivizado pelo desaparecimento do interesse pela atividade de nadar, o que acontece por anos a fio, significando uma duração considerável, do ponto de vista factual. Esse é um ato talvez inconsciente, que marca um afastamento temporário do sujeito das ocupações do PN. Em seguida, ele liga-se ao valor não-querer-não-fazer (reconsideração), em passagem figurativizada pela capacidade de rememorar o que lhe tinha acontecido no episódio da violação. O quererfazer, implicação natural dessa última modalidade, volta a vigorar no sujeito quando, no plano discursivo, o ator manifesta novamente o desejo de aprender a nadar.

No que tange à discursividade, é importante ressaltar que o ator realiza uma transição, saindo da espacialidade "protegida" na qual se encontrava (o local onde o grupo de crianças do coral estavam), para ingressar em outra, potencialmente mais perigosa, o fundo da piscina. A vontade de ir a esse lugar vinha do desejo de aprender a nadar (um querer-fazer em confrontação com um não-saber-fazer, em termos modais). A partir do momento no qual são reveladas as reais intenções do abusador, uma imposição que não é desejada pelo ator "SM28" acontece. No nível narrativo, a configuração modal altera-se, tornando-se uma associação do não-querer-fazer ao não-poder-não-fazer (confrontação contraditória entre essas duas categorias).

No trecho transcrito, verifica-se uma concomitância dos tempos do narrado com os da narração (expressa pela palavra "aGOra", enfatizada prosodicamente), o que traz o efeito de aproximação entre o então e o agora e procura passar ao narratário a impressão de que o reconhecimento do que tinha acontecido efetuava-se no momento da entrevista. Como visto acima, o uso do tempo da narração parece ocorrer mais nas passagens eufóricas dos discursos. No caso, isso é representado pelo alívio, vindo da recordação do episódio obscuro, que 
incomodava o ator "SM28". A partir do momento no qual ele se lembra do ocorrido, automaticamente, o desejo de nadar manifesta-se novamente.

A figura do esquecimento talvez possa ser atribuída ao que se denomina acontecimento disfórico, o que, no caso, está associado à experiência de abuso. Fruto da combinação entre intensidade e disforia, tal fenômeno teria ocorrido nessa passagem causando certa sublimação do ponto de vista psicológico da narradora. Nesse sentido, o caráter repulsivo do evento teria significado uma vivência ameaçadora (figurativizada pela invasão não desejada) que precisou ser, de certa forma, "apagada" da memória do ator para que este tivesse condições de lidar com as demais questões e demandas da vida que existiam entre o impacto da violação, o esquecimento e a rememoração do acontecido.

O trecho analisado traz, ainda, algumas referências ao que se podem considerar PNs de compensação, que buscavam, de algum modo, contrabalançar a dor da passagem (expressos nas palavras "minha mãe ficou:... super-revoltada mas... também eu acho que a gente não foi atrás... da pessoa"), mas que foram abandonados pelo sujeito, talvez pela falta de condições de lidar com a intensidade da situação em um primeiro momento. Com o alongamento na temporalidade ("a passagem dos anos"), a tonicidade disfórica diminui. Isso permite que ocorra, por parte do ator "SM28", a lembrança de pelo menos alguns elementos do que the havia acontecido.

A partir do estudo desse trecho de entrevista e da verificação das consequências psicológicas de tal ocorrência, a sensibilidade para essa problemática social faz-se inevitavelmente presente. Afinal, o abuso sexual de crianças no Brasil constitui crime hediondo 29 e essa passagem ilustra de maneira bastante explícita a permanência dessa falta gravíssima na sociedade brasileira e seu impacto na vida dos menores. A tomada de consciência da população diante dessas formas de violência sexual exercidas sobre crianças e adolescentes e o fim da naturalização das formas de exploração dos jovens são medidas urgentes, que precisam ser levadas a sério pelas autoridades. Leal (s/d, p. 4) trata deste conceito no âmbito da exploração das crianças e adolescentes das classes populares. A importância de organizações tais como o Violes (Grupo de Pesquisa sobre Tráfico de Pessoas, Violência e Exploração Sexual de Mulheres, Crianças e Adolescentes ${ }^{30}$ ) e outras que trabalham pelo combate a esse tipo de práticas na sociedade, vê-se reforçada a cada novo caso que não é evitado.

\footnotetext{
${ }^{29}$ No dia 21/05/2014 a Presidenta Dilma Roussef sancionou o projeto de lei aprovado pelo Congresso que torna crime hediondo o abuso e a exploração sexual de crianças e adolescentes.

30 Grupo articulado com o Decanato de Pesquisa e Pós-Graduação-DPP/UnB, site http://grupovioles.blogspot.com.br/
} 


\subsubsection{Juventude como passagem intensa}

Harkot-de-La-Taille, no artigo "Construção discursiva do adulto por jovens francesas: perspectiva dinâmica", mostra que a ideia de juventude, segundo a visão das pessoas "maduras", remete, por vezes, a um caráter de incompletude, seja pela comparação tardia quanto à idade das crianças (um "não mais"), seja pela precocidade que guarda quando visto com relação aos adultos (um "ainda não"). A crítica à visão da juventude como tempo de passagem e não como momento de presença, feita pela autora, recai também sobre a produção científica que investiga o ser jovem.

\footnotetext{
"Foco de diversas visadas teóricas, o jovem é perscrutado, auscultado, analisado. Nesse seu 'entre-lugar', entendido como no regime do 'não mais' e do 'ainda não',(5) o jovem é estudado, insistimos, a partir do lugar do adulto (6) - o 'ainda não' -, do ponto de vista das transformações, conquistas e dificuldades não conhecidas da criança - o 'não mais'." (Harkot-de-La-Taille, 2011, p. 3)
}

Harkot-de-La-Taille identifica uma construção até certo ponto usual na descrição da subjetividade da juventude que é feita a partir de estruturas linguísticas baseadas no "não mais" e no "ainda não". A autora conta que essas reflexões foram inspiradas por reflexões de JeanPaul Sartre que traz tais denominações aplicadas a outro contexto em L'être et Le Néant (1943). Essa formulação é própria de um estudo semiótico ou de cunho linguístico e atua como complementar à compreensão de que a adultez é o período no qual as pessoas são emocional e intelectualmente maduras, e que o jovem não estaria senão passando por um momento de preparação para esse que seria o período ideal da existência e o ápice do desenvolvimento humano.

Por coincidência ou não, a formulação "ainda não" parece desempenhar um papel um tanto quanto funcional na teoria tensiva. Segundo Lopes e Tatit, ela está associada à continuação da parada, no esquema de presença, posição que descreve o prosseguimento da disjunção entre sujeito e objeto (2008, p. 86). A partir dessa constatação, caberia perguntar se a juventude, segundo essa visão, não seria similar àquela da formulação concebida por Erik Erikson, que vê a etapa como uma moratória psicossocial (Identidade: Juventude e crise, 1972, mencionada por Imanishi, 2008, p. 24). Resumidamente, na proposta do autor, a etapa corresponderia a um "período de espera e maturação" dos indivíduos, antes de que estivessem aptos a comprometer-se com o mundo adulto e com a sociedade de modo geral. 
Dito isso, uma vez que é vista como um fenômeno de significação, a juventude pode ser analisada por um olhar aspectual. Os contornos distinguem-na da infância (ou da adolescência), anterior, e da adultez, posterior. O fato de que seja concebida como um período de pouca relevância não corresponde a uma necessidade do discurso, mas sim a uma postura pautada dentro de um determinado sistema de valores. Tratar cidadãos entre os 15 e os 29 anos como "não mais crianças" e "ainda não adultos" é relegá-los a um foco reduzido de atenção e pressupõe um descaso diante dessa importante passagem.

Os discursos analisados nas entrevistas mostram que essa etapa é marcada pela vivência de acontecimentos de grande intensidade. Mudanças-chave, tais como o abandono do lar familiar, o enquadramento profissional e a constituição dos fundamentos da identidade pessoal, entre outros elementos, frequentemente ocorrem nessa faixa de idade, mostrando que a juventude tende a ser um período marcante e veloz, no qual muitas transformações acontecem em pouco tempo. A tomada de consciência do aspecto nevrálgico dessa fase não deve ser negligenciada. O próprio discurso legal brasileiro vem procurando corrigir a falta de atenção dada ao segmento, por exemplo, por meio da aprovação do Projeto de Emenda Constitucional de n. $42 / 2008^{31}$.

Reconhecida a importância do segmento jovem, é interessante, antes de passar ao tópico seguinte, buscar ocorrências de acontecimentos eufóricos no corpus, uma vez que os estudos, até o presente momento, enfocaram principalmente a disforia. O depoimento de CS20 é o que mais traz elementos para isso. Um exemplo é quando menciona o envolvimento com a banda de música que transformou sua disposição diante da vida de modo geral. Além disso, ao contar que está grávida de seu primeiro filho, também comenta que vive um período de felicidade único, embora não deixe de mencionar as instabilidades do seu humor, "a partir do momento que uma pessoa/uma mulher fica grávida né?... ela sente muitas coisas... ela sente ela sente ela pode estar... triste... ao mesmo tempo ela pode estar feliz ao mesmo tempo ela pode estar... sorrindo... muitas coisas..." (Anexo, CS20, p. 8). A maternidade parece ocupar grande parte das suas expectativas de futuro, de modo que é a única entrevistada que não fala de transformação social e nem se preocupa muito quanto às perspectivas profissionais.

Um exemplo de realização eufórica encontra-se representado na conquista da vida independente de SM28, ao deixar a vida que levava em uma cidade pequena para viver em São Paulo (Anexo, p. 19). O estabelecimento desse caminho próprio igualmente relaciona-se mais

\footnotetext{
${ }^{31}$ A denominada PEC da Juventude regulamentou a proteção dos direitos econômicos, sociais e culturais do segmento, ao alterar a denominação do Capítulo VII do Título VIII da Constituição Federal e modificar seu art. 227, incluindo o termo "jovem" no texto da Carta Magna. Foi aprovada em 2010 pelo Congresso.
} 
com o que se denomina, no nível tensivo, sobrevir do que com o modo de eficiência do pervir. O entrevistado JS23, como visto no capítulo 3, "Narratividade da emancipação nas entrevistas", também comenta que foi com rapidez que se viu, em determinado momento de sua vida, já pagando as próprias contas e deixando a casa dos pais. Nesses dois últimos casos, do ponto de vista semiótico, é a presença do acontecimento eufórico que está regendo a aquisição de emancipação por parte do sujeito.

Por outro lado, alguns dos eventos que são recebidos com alegria pelos jovens entrevistados são marcados pelo pervir. Devido a seu caráter implicativo e esperado, este modo de eficiência conta com uma progressividade "controlada" no sentido da construção de intensidade. Nas ocorrências que acontecem dessa maneira, costumam verificar-se investimentos discursivos temáticos como conquistas e crescimento. Ele ocorre, por exemplo, no caso da entrevista de JS23, quando ele entra na universidade e consegue com esforço manter-se estudando dentro da instituição, construindo um senso de êxito a partir das vitórias cotidianas diante das dificuldades (Anexo, p. 10).

\subsection{Reflexões sobre aspectualidade e ensino superior no país}

Dentro da narratividade, as figuras que se relacionam à formação e, mais especificamente, ao ensino superior estão vinculadas, geralmente, ao que se denomina etapa da competencialização. Nela, o sujeito entra em conjunção com o saber e com o poder-fazer e torna-se, assim, apto a realizar a ação. No corpus estudado, essas duas modalidades encontramse também, por vezes, relacionadas com a figura ocupação de lugares profissionais.

No capítulo anterior, houve alguma reflexão sobre o acesso à universidade e viu-se como, para os jovens entrevistados de modo geral, a figura do vestibular possui uma importância no estabelecimento das possibilidades de inserção no mercado de trabalho. Zilberberg (2011, p. 175) associa a ideia de importância à tonicidade tensiva, a partir da definição de acontecimento do dicionário Micro-Robert, de francês ("aquilo que ocorre e tem importância para o homem"). Do ponto de vista aspectual, esse fato pode ser considerado uma passagem de caráter saliente, haja vista que não é processual (não há meio termo: ingressa-se ou não na faculdade). Tal processo de seleção é relacionado ao fenômeno tensivo da triagem, pois significa uma restrição no eixo da extensidade, figurativizado pelo acesso aos cursos superiores (2011, p. 290). Nos discursos analisados, essa passagem aparece usualmente acompanhada do que se 
denomina um aumento de tonicidade, como prevê a curva ascendente de correlação inversa do esquema tensivo (p. 245).

Segundo Barreto (p. 169), citando Antonio Sérgio Alfredo Guimarães (New ideological inflections in the study of racism in Brazil, 2007), embora parte do ensino superior de qualidade no país seja público e gratuito, o ensino médio de qualidade é privado e pago. Isso faz com que as chances de mobilidade social por meio da educação superior sejam diminutas para as classes populares no Brasil. Algumas iniciativas por parte do governo vêm procurando trazer modificações a esse cenário, tais como o Prouni (Programa Universidade para Todos) e o Sisu (Sistema de Seleção Unificada). Diversas universidades públicas do país também têm regulamentado o acesso de alunos implementando cotas para os cursos, em complementaridade com os programas mencionados acima. Os critérios que são levados em conta para o estabelecimento dessas cotas são econômicos e étnico-raciais ${ }^{32}$.

O Prouni, implementado pelo Governo Federal em 2005, a despeito das críticas que recebe por ser um mecanismo que, de certo modo, terceiriza a educação universitária por meio da concessão de isenções ficais a entidades de ensino privadas, tem atuado como um mecanismo de oferta de bolsas de estudo em nível superior. O número de vagas concedidas no segundo semestre de 2014 foi de 115.101 (73.601 integrais e 41.500 parciais, concedendo 50\% de financiamento, segundo o site do programa, cf. URL na seção de referências bibliográficas). Outros programas governamentais (Fundo de Financiamento Estudantil, o Fies, e Programa de Apoio a Planos de Reestruturação e Expansão das Universidades Federais - Reuni) também têm atuado no sentido de tornar mais democrático o acesso aos cursos superiores ${ }^{33}$.

Ainda a título de contextualização, Scholz, Carvalho, Azevedo e Santos (2008) mencionam a problemática da não conclusão de cursos de ensino superior, trazendo índices que revelam o percentual elevado de alunos que, embora matriculados nas faculdades de engenharia e direito, não chegam a completá-las - $41 \%$ na primeira e $38 \%$ na segunda (p. 68). Qualquer resolução por parte de iniciativas que visem reduzir as desigualdades sociais no acesso à universidade exige a compreensão sistêmica do funcionamento dessa transição.

As entrevistas do corpus apontam para o fato, já constatado, de que não existe ainda uma democratização efetiva do ensino superior, embora esse quadro venha melhorando a partir das ações que vêm sendo tomadas no sentido da reversão do quadro de desigualdades

\footnotetext{
32 O Prof. Kabenguelê Munanga, em entrevista concedida ao Portal Fórum (9 de fevereiro de 2002, p. 2), traz mais informação a respeito desse processo.

${ }^{33}$ http://portal.mec.gov.br/, consultado em 17/11/2014.
} 
(Andrade, 2012). Se os jovens brasileiros transitam por procedimentos que podem ser associados ao conceito de triagem, pelo menos no que tange ao acesso à faculdade, por outro lado, as novas tecnologias e a difusão da informação, atuando por vias que não as do ensino formal, desempenham, mesmo nos contextos sociais menos favorecidos, o papel de disseminadores de conhecimento, narrativas e estímulos visuais, estando, assim, associadas ao que se denomina mistura, nos termos tensivos (Zilberberg, 2011, pp. 268-269).

Segundo dados do IBGE, em 2011, dos cidadãos brasileiros entre 15 e 17 anos, 74,1 \% haviam utilizado a internet no período de referência estudado, de três meses ${ }^{34}$. Quando são levadas em consideração as faixas de 18 a 19, 20 a 24 e 25 a 29 anos, esses números são, respectivamente, $71,8 \%, 66,4 \%$ e $60,3 \%$. Como se vê, o acesso à rede é uma comodidade que a maioria da população nacional possui a seu alcance, guardadas as diferenças na acessibilidade (computador próprio na residência, uso em lan houses etc.). Pode-se considerar, portanto, que a difusão dessa forma de comunicação representa uma ampliação das fontes de saber dos jovens, que permite que mesmo aqueles que não puderam ingressar em uma instituição de ensino superior tenham mais contato com conhecimentos e meios de comunicação variados. As trocas interpessoais presenciais (que, obviamente, independem desses recursos), por outro lado, também representam fontes de informação significativas para os indivíduos e não podem deixar de ser levadas em conta no âmbito desse raciocínio, constituindo outro importante elemento para a aquisição de saber dos cidadãos.

Voltando às considerações sobre emancipação feitas com base em ferramentas semióticas, pode-se dizer que a aspectualidade traz um instrumental interessante para tratar 0 jogo entre a continuidade e a descontinuidade da educação formal, a qual se verifica nos depoimentos. Nesse âmbito, o acesso associa-se à incoatividade e a ideia de permanência encontra-se ligada à duratividade da presença dos indivíduos nas instituições de ensino. Os índices de conclusão (e de abandono) de estudos (universitários e escolares) por parte de jovens, por sua vez, estão ligados à terminatividade. Os estudos tensivos indicam que a pontualidade (extensidade mínima) possui uma tendência de ser mais intensa do que as passagens processuais. Assim sendo, não é de se espantar o fato de que muitas das considerações do corpus recaem sobre os acessos e as saídas das universidades. As observações referentes à permanência nos estudos (ou fora deles), por vezes, ficam em um segundo plano, por serem menos impactantes. Além disso, como mencionado, o ingresso no ensino superior é uma das

\footnotetext{
${ }^{34}$ IBGE, Pesquisa Nacional por Amostra de Domicílios 2011.
} 
principais figuras que investem a competencialização narrativa considerada necessária à vida emancipada dos jovens entrevistados, daí, haver tanta referência a essa transição nos textos.

Algumas das críticas encontradas nos depoimentos quanto às ações institucionais voltadas à juventude recaem sobre a falta de continuidade das ações que visam a transformação e a redução das desigualdades. JS23, em trecho já mencionado, ressalta a necessidade de um acompanhamento à concessão de bolsas de estudo ou de vagas de trabalho, que garanta as condições de manutenção dos jovens nos novos postos. CS20 considera que sua escola é uma bagunça. Em termos aspectuais, essas duas considerações remetem à presença de características descontínuas no ambiente educativo (processos iniciados sem ser terminados, coisas fora do lugar, acordos não cumpridos), que prejudicam as práticas. Nesse sentido, embora existam iniciativas de redução e reparação dos descompassos sociais e raciais nos projetos de formação de jovens no Brasil, em geral, elas carecem de elementos que garantam suas efetividades e durações.

Ao criticar as ações formativas e de reparação de desigualdades sociais por sua descontinuidade, a insatisfação dos jovens serve como uma fonte de informações para que se possam elaborar iniciativas em educação, cultura e assistência social voltadas a esse segmento. A partir do que se verifica no presente corpus, é preciso dar mais atenção àquelas que valorizam mais o cumprimento dos contratos estabelecidos com os jovens e que zelam pela duratividade de seus resultados. 


\section{Conclusão}

Se emancipação é um conceito amplo, que se refere a uma passagem (mais ou menos durativa) do que pode ser considerado o processo de libertação dos seres, por outro lado, a análise do corpus representado pelas entrevistas trouxe informações que servem para a compreensão de uma transição mais específica, aquela que acontece durante a vida das pessoas, na etapa da juventude. Ambos os focos de análise são dignos de menção, pois, dentro das limitações que deste estudo, cada um deles acrescenta algo à compreensão do fenômeno da emancipação, seja ele entendido como uma construção de sentido ampla, utilizável em vários contextos e usos, seja como uma passagem marcada por um investimento discursivo específico ("a etapa da juventude").

No que tange ao conceito mais geral de emancipação, do ponto de vista narrativo, viuse reforçada a tese de que este refere-se, em última instância, à aquisição das modalidades da liberdade (poder-fazer) e da independência (poder-não-fazer) por parte do sujeito. Contudo, não é possível desconsiderar, nesse âmbito, a importância das outras modalidades previstas pelo instrumental teórico (crer, querer, dever e saber), também vistas como necessárias para a conjunção com o atributo em questão. A modalidade potencial, em suas duas formas de manifestação (assumir e aderir), tem papel especial nesse processo, uma vez que, como estabelecem Fontanille e Zilberberg (2001, p. 254), é por meio delas que o estabelecimento de cada uma das categorias mencionadas acima pode ocorrer.

A emancipação remete, narrativamente, a um valor adquirido por meio da manipulação. Esta, por vezes, ocorre sob um regime reflexivo, no qual destinador e destinatário sincretizamse em um só ator discursivo. Isso sugere um circuito relativamente fechado, no sentido de que não existe dependência de qualquer ator externo para que a ação se efetive. Por outro lado, o fazer-fazer transitivo, embora tenha uma presença menos marcante nesse âmbito, também é parte do processo e não deve ser desconsiderado como forma de manifestação narrativa da emancipação.

Do ponto de vista tensivo, a juventude mostra-se uma etapa marcada pelo que se denomina acontecimento (Zilberberg, 2011, pp. 235 - 236). Tal afirmação pode ser feita pelo caráter relativamente destacado dessa transição no que é o percurso de vida das pessoas. Em alguns casos, ela representa o momento no qual se dá a construção dos alicerces que sustentarão os indivíduos quando adultos. Se é verdade que mudanças e reestruturações 
ocorrem ao longo de toda a trajetória vital (mesmo na velhice, na qual a força dos hábitos tende a estar mais "cristalizada"), o período entre a infância e a adultez é, certamente, um momento privilegiado de formação, no qual ocorre a tomada de importantes decisões. Muitas das definições que se estabelecem nessa fase remetem a práticas que podem durar por muitos anos, marcando a vida das pessoas, mesmo que, mais adiante no caminho de cada um, algumas das escolhas feitas durante esse período terminem por ser alteradas.

As opções pessoais que podem ser consideradas "típicas" do período da juventude acontecem dentro do campo semântico de temas como moradia (figurativizado pela "saída da casa dos pais", entre outros investimentos discursivos), relacionamentos ( "constituição de família própria ou de grupo de amigos", etc.), ofício ("profissão") ou até sociabilidade (figurativizado pela "aquisição das responsabilidades e atribuições da vida civil", por exemplo). Essas escolhas transitam por uma variedade de campos do sentido, tanto naqueles mais ligados à individualidade e ao âmbito da vida privada, quanto em outros, vinculados a assuntos coletivos ou da vida pública. Desse modo, vê-se que as passagens da juventude parecem remeter às subdimensões tensivas da tonicidade elevada e do andamento acelerado, ao mesmo tempo em que as decisões importantes que lhe são inerentes parecem ocorrer em variadas frentes da experiência dos indivíduos no mundo. Elas podem, portanto, ser consideradas, até certo ponto, generalizadas dentro desse período. Sendo as mudanças, nessa fase, ocorrências relativamente disseminadas - indo desde as alterações no próprio corpo até as decisões quanto aos caminhos profissionais ou pessoais de cada indivíduo - isso faz com que a juventude termine por ser expressa nos discursos, muitas vezes, como uma etapa especialmente conflitiva.

Como visto no capítulo 4, "Comentários tensivos e extratextuais", a vivência do acontecimento pode provocar a necessidade de uma atenuação ou de uma desaceleração no que é a experiência do sujeito, até como uma forma de preencher as lacunas de identidade que porventura tenham sido perdidas durante o impacto do sofrido (Tatit, 2010, p. 81). Essas formas de compensação da intensidade, por vezes, correspondem a uma busca por espacialidades abertas ou temporalidades duradouras, que não se encontravam à disposição do sujeito, em um primeiro momento. A disposição e o interesse de encontrar mecanismos que permitam elaborar internamente o fluxo do acontecimento - recorrentes no discurso dos jovens entrevistados - são formas que eles encontram de "dar vazão" aos excessos sentidos, "diluindo" o impacto de situações difíceis que foram vividas. Essas estratégias de superação dos imprevistos expressamse em variados campos de suas práticas, sejam elas profissionais, pessoais, culturais, etc. Isso pode ser identificado, por exemplo, no caso do profundo envolvimento de CS20 com a música, ou naquele da atuação esmerada de AV24 pela transformação da sua comunidade. 
De modo geral, diferenciam-se no corpus dois grandes tipos de dificuldade que precisam ser enfrentadas durante a transição à fase adulta. A primeira delas remete a questões mais "naturais", tais como a indecisão profissional ou os relacionamentos, por exemplo. Trata-se de impasses relativamente previsíveis para as pessoas. Mas há, ainda, obstáculos menos previsíveis tais como as violações de direitos, que, além de serem preocupantes por si, por vezes estigmatizam os jovens e terminam por provocar consequências sociais graves. O abuso sexual, por exemplo, representa uma forma de manifestação desse fenômeno que foi verificada nos textos e que requer atenção especial por parte das organizações que zelam pelos jovens.

Do ponto de vista modal, vê-se que o segundo tipo de dificuldade mencionado acima, por vezes, é responsável pelo que se denomina, em um nível narrativo, instalação dos valores de não-querer-fazer (indisposição) ou querer-não-fazer (abulia). A ação está investida, nesses casos, por figuras que remetem a atividades essenciais da vida, tais como "estudar", "trabalhar" ou "relacionar-se". A conjunção com as modalidades acima mencionadas interrompe o prosseguimento do programa narrativo. Essa alteração no estado volitivo do sujeito, em um nível social, significa, entre outras coisas, um enfraquecimento da participação dos jovens como cidadãos, comprometendo as suas vidas na coletividade. Todos os jovens que forneceram relatos para esta dissertação relataram ter vivenciado pelo menos uma passagem de violação de seus direitos civis durante os seus percursos de emancipação. Esse tipo de evento terminou por ser descrito analiticamente sob a denominação acontecimento disfórico.

A manifestação de alongamentos no eixo da extensidade, uma das respostas subjetivas ao acontecimento disfórico, por vezes se deu em concomitância com o que se denomina, nos modos de presença, continuação da parada ("ainda não") ou, em outros termos, com uma consolidação da disjunção entre sujeito e objeto, mantidos em um estado de retenção (Lopes e Tatit, 2008, p. 86). Isso acontece, por exemplo, no relato de SM28, quando conta que, por conta de experiência traumática vivida, passou um longo período negando o desejo de aprender a nadar.

A partir das reflexões acima, constata-se que, do ponto de vista semiótico, o acontecimento disfórico por vezes faz cessar a conjunção do sujeito narrativo com o objeto de valor. No plano factual dos relatos em questão, isso significa que as trajetórias dos jovens se veem interrompidas por tais eventos, gerando uma série de consequências que levam tempo para serem superadas. Se, por um lado, seria equivocado afirmar que todo acontecimento disfórico é investido discursivamente por violações de direitos, por outro, vê-se que, geralmente, esse tipo de ocorrência, vivido no âmbito (antis)social, afeta o sujeito narrativo com 
uma alta intensidade, sendo, igualmente, apreendido por ele por meio de um tom disfórico. Uma exceção a isso seriam as situações de "anestesiamento", que compreendem um silenciamento da sensação provada pelo sujeito, em razão da continuidade dos programas que se encontravam em curso e que, por algum motivo, não podiam ser interrompidos naquela ocasião.

Compreender de maneira apurada as condições de produção dos acontecimentos disfóricos, é também, de certa forma, caminhar em busca da compreensão dos "caminhos" que levam à prevenção e à reversão das consequências negativas das violações de direitos. A escuta e a análise de textos que falam sobre experiências traumáticas (e suas superações) permite, em certa medida, entender as trajetórias dos indivíduos que as vivenciaram. Pessoas que passaram ou passam por experiências similares, e que talvez ainda se encontrem imersas na dor do impacto sofrido, possivelmente receberão alguma contribuição para o encaminhamento de suas histórias a partir da tomada de consciência de casos similares e do incentivo ao diálogo sobre o assunto.

No que tange às constatações do nível discursivo, os resultados obtidos por este estudo, entre outras coisas, apontam para uma "dialética" que se dá entre as manifestações actoriais individuais e coletivas. A conjunção com o valor independência, por exemplo, pode estar investida simultaneamente com os temas da conquista pessoal e social. Os jovens entrevistados, para sentir-se realizados em seus anseios, além de bons desempenhos individuais (no campo profissional, por exemplo), anseiam por uma melhoria nas condições de vida das comunidades nas quais habitam. Esse ator discursivo, ao fazer uso de uma estrutura coletiva, exige a consecução de objetivos de todos os personagens que lhe são constituintes para levar a cabo o que poderia ser considerado realização narrativa.

Verifica-se, em geral, no discurso dos entrevistados, uma preocupação e um cuidado pelas pessoas que vivem em suas cotidianidades. JS23 menciona a "zona de conforto" como um espaço metafórico que seria ocupado por indivíduos que não se interessam pelos desafios da vida em sociedade de modo geral. Opõe sua postura pessoal à desses sujeitos, pois, diante das desigualdades e dos obstáculos no caminho da emancipação, o jovem engaja-se de modo contínuo no sentido de encontrar-se com as situações conflitivas para superá-las (Anexo, pp. 12 -14). A expressão "zona de conforto", vista como disfórica pelo discurso por representar o tema estagnação, representa um lugar de conformidade com as coisas "tal como elas são". Assim, nega, por parte do ator discursivo, qualquer movimento no sentido da transformação das realidades sociais. 
Segundo a fala de alguns dos entrevistados, a alteração da realidade social do país como um "sonho comum" - é fonte de motivação e sentido para a vida. Olhando a passagem do ponto de vista narrativo, vê-se um PN amplo, investido pela transformação social propriamente dita, acompanhado de programas menos abrangentes ("as vitórias sobre desigualdades no cotidiano"), mas que, pouco a pouco, contribuem para vencer as desigualdades mais profundas. De modo geral, a ação transformadora desses jovens não visa apenas a aquisição do valor liberdade (poder-fazer), mas também a conjunção com a independência (poder-não-fazer).

Os entrevistados da presente dissertação não podem ser considerados representantes da "geração canguru" 35 , que se caracteriza por hesitar no momento da saída da residência familiar, embora tenha todas as condições de estabelecer moradias independentes. Encontramse sintonizados com a tendência, constatada por Pimenta (2007), que diz que "os jovens de classes trabalhadoras (...) tendem a realizar a passagem para o mundo do trabalho (...) bem mais cedo do que jovens de classes mais favorecidas" (p. 25). O fato de começarem a trabalhar com relativa precocidade representa não só a aquisição das condições necessárias ao sustento próprio, mas também o ingresso no "mundo" das relações sociais que extrapolam o âmbito familiar. O discurso dos entrevistados revela a compreensão de que os encaminhamentos pessoais podem ser considerados posicionamentos políticos, sempre que significarem também responsabilidade com os efeitos das ações individuais sobre o ambiente e a sociedade nas quais encontram-se inseridos. O envolvimento deles com os seus trabalhos mostra que possuem senso de inserção social, além de valorizarem as relações com suas famílias.

As emancipações aqui encontradas, individuais mas não individualistas, atuam a partir do reconhecimento das potencialidades e das razões que levam cada sujeito a querer (ou sentir que deve) percorrer o seu caminho. Além disso, em mais de uma ocorrência, a atuação no sentido de um engajamento por parte dos jovens correspondeu também à forma que eles encontraram de lidar com os sentimentos negativos que vigoravam nas suas sensibilidades, decorrentes de experiências difíceis que marcaram suas histórias. Mais uma vez, reforça-se a ideia de que uma aparente desmobilização da juventude dos dias de hoje não corresponde ao abandono dos interesses da esfera pública, mas, sim, à gestação de uma nova maneira de atuar pela transformação social, fundada na defesa dos valores das pessoas diante do estar no mundo e em condições de lidar com os traços voláteis da contemporaneidade.

\footnotetext{
${ }^{35}$ Pimenta (2007, p. 19) menciona esse conceito, retirado de reportagem de capa da Revista Época, $n$. 332, 27/09/2004, "Mordomias na casa dos pais", pp. 76 - 82, feita a partir de pesquisa da psicóloga e terapeuta de família Célia Regina Henriques.
} 


\section{Referências bibliográficas}

ALMEIDA, Kátia Lorena Novais (2007) Da prática costumeira à alforria legal. In: Politeia: Hist. E Soc., Vitória da Conquista, v. 7, n. 1, p. $163-186$.

ALVES, José Eustáquio Diniz; CAVENAGHI, Suzana Marta (2013) Indicadores de desigualdade de gênero no Brasil. In: Mediações, Revista de Ciência Sociais / Dossiê - Análises quantitativas e indicadores sociais, vol. 18, n. 1, Londrina.

ANDRADE, Aline e MUSSI, Mônica (2008) Vida Contemporânea: alguns pontos de partida para se pensar as juventudes. In: Cadernos CENPEC / Centro de Estudos e Pesquisas em Educação, Cultura e Ação Comunitária, n. 5, pp. 25-31. São Paulo: CENPEC.

ANDRADE, Cibele Yahn de (2012) Acesso ao ensino superior no Brasil: equidade e desigualdade social. In: Ensino Superior UNICAMP, disponível em: <

https://www.revistaensinosuperior.gr.unicamp.br/artigos/acesso-ao-ensino-superior-nobrasil-equidade-e-desigualdade-social $>$, acessado em 26/02/2015.

ARAÚJO, Maria de Fatima (2002) Violência e abuso sexual na família. Psicologia em estudo, Maringá, v. 7, n. 2, pp. $3-11$, jul/dez.

ARAÚJO, Rosângela Costa (2004) lê, viva meu Mestre / A Capoeira Angola da "escola pastiniana" como práxis educativa. São Paulo: Faculdade de Educação, Universidade de São Paulo.

BARRETO, Paula Cristina da Silva (2008) Múltiplas vozes: racismo e antirracismo na perspectiva dos universitários de São Paulo. Salvador: EDUFBA.

BARROS, Diana Luz Pessoa de (2002) Teoria do discurso: fundamentos teóricos. 3a ed. São Paulo: Humanitas.

BARROS, Diana Luz Pessoa de (2003) Estudos do discurso. In: Introdução à Linguística II / Princípios de análise. José Luiz Fiorin (org.), São Paulo: Contexto, p 187-219.

BAUMAN, Zygmunt (2004) Amor líquido: sobre a fragilidade das relações humanas. Rio de Janeiro: Jorge Zahar.

BEIVIDAS, Waldir (2002) Inconsciente et verbum, 2a . Ed. São Paulo: Humanitas.

BEIVIDAS, Waldir; LOPES, Ivã Carlos (2009) Argumentação e persuasão: tensão entre crer e saber em “Famigerado" de Guimarães Rosa. Revista Alfa. São Paulo, v. 53 (2): p. 443-455. BERTRAND, Denis (2003). Caminhos da semiótica literária. Trad. Grupo CASA.

Bauru, SP: EDUSC

FERREIRA, Aurélio Buarque de Holanda (1995) Dicionário Aurélio Básico da Língua Portuguesa. São Paulo: Nova Fronteira, Folha de São Paulo. 
FIORIN, José Luiz (1995) A pessoa desdobrada. Revista Alfa. São Paulo, v. 39, p. 23-44.

FIORIN, José Luiz (1996) As astúcias da enunciação: as categorias de pessoa, espaço e tempo.

São Paulo: Ática.

FIORIN, José Luiz (2007). O sujeito na semiótica narrativa e discursiva. Todas as Letras, São

Paulo, v. 9, p. 24-31, disponível em: <

http://editorarevistas.mackenzie.br/index.php/tl/article/viewFile/649/579 $>$, acessado em 20/01/2014.

FIORIN, José Luiz (2012). Em busca do sentido: estudos discursivos. 2a ed. São Paulo: Contexto. FONTANILLE, Jacques; GREIMAS, Algirdas Julien (1993) Semiótica das Paixões / Dos estados de coisa aos estados de alma, trad. Maria José Rodrigues Coracini. São Paulo: Ática.

FONTANILLE, Jacques; ZILBERBERG, Claude (2001) Tensão e Significação. Trad. I. C. Lopes; W. Beividas; L. Tatit. São Paulo: Discurso Editorial: Humanitas.

GOMES, Nilma Lino; MUNANGA, Kabenguelê (2006) O negro no Brasil de hoje. São Paulo:

Global

GUERRA, Isabel Carvalho (2006) Pesquisa qualitativa e análise de conteúdo / Sentidos e formas de uso, Estoril: Princípia.

GREIMAS, Algirdas Julien (1973) Semântica estrutural: pesquisa de método. Trad. Haquira Okasabe, Isidoro Blikstein. São Paulo: Editora Cultrix, Editora da Universidade de São Paulo. GREIMAS, Algirdas Julien (1975) Sobre o sentido: ensaios semióticos. Trad. Ana Cristina Cruz Cesar [e outros], revisão técnica de Milton José Pinto. Petrópolis: Vozes.

GREIMAS, Algirdas Julien (1983) Du Sens II: Essais sémiotiques. Paris: Éditions du Seuil. GREIMAS, Algirdas Julien; COURTÉS, Joseph (2012) Dicionário de semiótica. 2ae ed. 1aㅡ reimpressão. Vários tradutores. São Paulo: Contexto. Título original: Semiótique, dictionnaire raisonné de la théorie du langage.

GREIMAS, Algirdas Julien (2014) Sobre o sentido II: ensaios semióticos (Trad. Dilson Ferreira da Cruz). São Paulo: Nankin: Edusp.

HARKOT-DE-LA-TAILLE, Elizabeth (2011). Construção discursiva do adulto por jovens francesas: perspectiva dinâmica. Cadernos de Semiótica Aplicada, Araraquara, v. 9 n 1, p. 1-20. HARKOT-DE-LA-TAILLE, Elizabeth; BARIAUD, Françoise (2013) "Ser adulto", por jovens francesas e brasileiras em 2007 - 2010. In: Língua, discurso e processos de subjetivação na contemporaneidade. Anna Maria Grammativo Carmagnani e Marisa Grigoletto (orgs). São Paulo: Humanitas.

HJELMSLEV, Louis (1975) Prolegômenos a uma teoria da linguagem. Trad. José Teixeira Coelho Neto. São Paulo: Perspectiva. 
HOUAISS, Antonio (s/d) Grande Dicionário Houaiss Beta da Língua Portuguesa. Secretaria de Cultura do Rio de Janeiro, Ministério da Cultura, UOL.

IMANISHI, Helena Amstalden (2008) A imagem do adulto na contemporaneidade: uma avaliação dos jovens sobre os adultos. São Paulo: Universidade de São Paulo, Instituto de Psicologia.

JONES, J. Background to D. T. Niane, Sundjata: An Epic of Old Mali translated by G. D. Pickett (Harlow, England: Longman Drumbeat, 1965, 1982) West Chester University of Pennsylvania (c.2003). Disponível em: < http://courses.wcupa.edu/jones/his311/notes/sundiata.htm >, acessado em: 08/04/0214.

LANDOWSKI, Eric (2005) Para uma semiótica sensível. Revista Educação \& Realidade. Vol 30, n. II, UFRGS, disponível em: <

http://seer.ufrgs.br/educacaoerealidade/article/viewFile/12417/7347 > acessado em $24 / 11 / 2014$

LAROUSSE, P.; AUGÉ, C. (1968) Nouveau Petit Larousse en couleurs. Paris: Librairie Larousse. LEAL, Maria Lúcia Pinto (s/d) Crianças e adolescentes no mercado do sexo: fetichismo e precarização. Disponível em: < http://grupovioles.blogspot.com.br/ >acessado em 12/11/2014. LELLO, J.; LELLO E. (1962) Novo Dicionário Francês- Português / composto em conformidade com os melhores e mais modernos dicionários. Porto: Lello \& irmãos - editores.

LOPES, Edward. Fundamentos da Linguística Contemporânea (2008) 20a Ed. São Paulo: Cultrix. MACHADO, Sara Abreu da Mata (2011) Comunidade e africanidade na Capoeira Angola: jogo de muleekes entre a pequena e a grande rodas. In: V Colóquio Internacional "Educação e Contemporaneidade", São Cristovão, SE, 21 a 23 de setembro de 2011. Disponível em: < http://www.educonufs.com.br/vcoloquio/cdcoloquio/cdroom/eixo\%202/PDF/Microsoft\%20W ord\%20-\%20Comunidade\%20e\%20africanidade\%20na\%20capoeira\%20angola.pdf > acessado em outubro de 2012.

MARTINS, Jose de Souza (2008) Os novos analfabetos da modernidade. Jornal O estado de S. Paulo. Suplementos. Aliás. Domingo, 27/01/2008. Disponível em: <

http://alias.estadao.com.br/noticias/geral,os-novos-analfabetos-da-modernidade,115788 > acessado em 07/11/2014.

MEIHY, José Carlos Sebe Bom (1996) Manual de História Oral. São Paulo: Edições Loyola. MOTTA, Ana Raquel; SALGADO, Luciana, orgs. (2008). Ethos discursivo. 1a ed. 1a impressão. São Paulo: Contexto.

NIANE, Djibril Tamsir (1982) Sundjata, ou A epopéia mandinga, Trad. Oswaldo Biato. Col. De Autores Africanos / Senegal. São Paulo: Ática.

NIANE, Djibril Tamsir (1960) Soundjata ou L'épopée Mandingue. Paris: Présence Africaine. 
PAIXÃO, Marcelo; ROSSETO, Irene; MONTOVANELE, Fabiana e CARVANO, Luiz M., orgs. (2010) PEREIRA, Eliane Domaneschi (2014) Crer e saber: relações de precedência e hierarquização. Revista Estudos Semióticos, São Paulo, vol 10, n. 1, pp 69 - 75.

PIMENTA, Melissa de Mattos (2007) "Ser jovem" e "ser adulto": identidades, representações e trajetórias. São Paulo: Universidade de São Paulo, Departamento de Sociologia.

PRETI, Dino (2000) (org.) Fala e escrita em questão. São Paulo: Humanitas / FFLCH / USP. RICOEUR, Paul (2004) Parcours de la reconnaissance: trois études. Paris: Stock. ROSA, João Guimarães (2001) Primeiras Estórias. 15 ed., 2a reimpressão, Rio de Janeiro: Nova Fronteira.

SAUSSURE, Ferdinand de (1969) Curso de Linguística Geral. São Paulo: Cultrix/Edusp. SCHOLZ, Cley, CARVALHO, Maria do Carmo Brandt de, AZEVEDO, Maria Julia, SANTOS, Wagner A. (2008) Jovem e trabalho. Cadernoscenpec. N. 5 / Juventudes urbanas. São Paulo: CENPEC 2006

TATIT, Luiz (2001) Análise semiótica através das letras. São Paulo: Ateliê Editorial. TATIT, Luiz (2010) Semiótica à luz de Guimarães Rosa. São Paulo: Ateliê Editorial. TATIT, Luiz; LOPES, Ivã Carlos (2008) Elos de Melodia e Letra: análise semiótica de seis canções. Cotia, SP: Ateliê Editorial.

ZILBERBERG, Claude (2006) Razão e poética do sentido. Trad. Ivã Carlos Lopes; Luiz Tatit; Waldir Beividas. São Paulo: Editora Universidade de São Paulo.

ZILBERBERG, Claude (2011) Elementos de Semiótica Tensiva. Trad. I. C. Lopes; L. Tatit; W. Beividas. São Paulo: Ateliê Editorial.

\section{Referências da internet e de autoria institucional}

Ação Educativa < http://www.acaoeducativa.org/ > acessado em outubro de 2012 Banco União Sampaio. < http://bancocomunitariosampaio.blogspot.com.br/ > acessado em outubro de 2012.

Blog Conexão África. < http://conexaoafrica.com/tag/soundjata-keita/ > acessado em $19 / 02 / 2014$.

Brasil. Casa Civil, Subchefia para assuntos jurídicos (1990) Estatuto da Criança e do Adolescente. Lei n. 8069. 13 de julho de $1990<$ http://www. planalto.gov.br/ccivil 03/leis/L8069.htm > acessado em outubro de 2012. Brasil. Casa Civil, Subchefia para assuntos jurídicos (2002) Código Civil. Lei 10.406, de 10 de janeiro de 2002 < http://www.planalto.gov.br/ccivil 03/leis/2002/l10406.htm > acessado em janeiro de 2013. 
Brasil. Casa Civil, Subchefia para assuntos jurídicos (2013) Estatuto da Juventude. Lei 12.852, de 5 de agosto de 2013 < http://www.planalto.gov.br/ccivil 03/ Ato20112014/2013/Lei/L12852.htm > acessado em janeiro de 2013.

CENPEC, Centro de Estudos e Pesquisas em Educação, Cultura e Ação Comunitária < http://www.cenpec.org.br/ > acessado em outubro de 2012.

Conselho Nacional da Juventude - CONJUVE (2009) PEC da Juventude n. 42/2008 / O Brasil precisa, a Juventude quer! Brasília, maio de 2009 < http://www.secretariageral.gov.br/Juventude/marcos-da-politica-nacional-dejuventude/PEC\%20da\%20Juventude\%20Revisado 05.05.20091.pdf > acessado em 04/04/2014.

Grupo de Pesquisa sobre Tráfico de Pessoas, Violência e Exploração Sexual de Mulheres Crianças e Adolescentes - VIOLES. < http://grupovioles.blogspot.com.br/ > acessado em 08/04/2013.

IBGE (s/d) População jovem no Brasil: a dimensão demográfica. Disponível em: < http://www.ibge.gov.br/home/estatistica/populacao/populacao jovem brasil/comentario1.p df $>$ Acessado em setembro de 2012.

IBGE (2011) Pesquisa Nacional por Amostra de Domicílios 2011. Disponível em: < ftp://ftp.ibge.gov.br/Acesso a internet e posse celular/2011/tabelas pdf/tab1023.pdf > acessado em março de 2015.

Ministério da Educação. Número de bolsas ofertadas pelo Prouni para o segundo semestre de 2014. <

http://prouniportal.mec.gov.br/images/arquivos/pdf/Quadros informativos/numero bolsas ofertadas por uf segundo semestre 2014. pdf > acessado em 28/10/2014.

ONUBR, Organização das Nações Unidas no Brasil (2012) ONU lança relatório sobre cidades latino-americanas, disponível em: < http://www.onu.org.br/cidades-al-caribe-2012/ > acessado em 27/02/2013.

Relatório das Desigualdades Raciais no Brasil 2009-2010: Constituição Cidadã, seguridade social e seus efeitos sobre as assimetrias de cor ou raça. Rio de Janeiro: Garamond/Laeser/ UFRJ Instituto de Economia. Disponível em: < http://www.palmares.gov.br/wpcontent/uploads/2011/09/desigualdades raciais 2009-2010.pdf > acessado em abril de 2014. Universo On-Line (2013) Brasil tem 3a maior taxa de evasão escolar entre 100 países, diz Pnud. Publicado em 14/03/2013, disponível em: < http://educacao.uol.com.br/noticias/2013/03/14/brasil-tem-3-maior-taxa-de-evasao-escolarentre-100-paises-diz-pnud.htm > acessado em 20/02/2015. 


\section{ANEXO}

\section{ENTREVISTA COM A. V., 24 ANOS, HOMEM, FEITA NO DIA 7 DE JANEIRO DE 2014}

E: então... é... para começar... eu queria que você falasse seu nome... profissão e... basicamente isso... data de nascimento também

A: meu nome é A. V... tenho 24 anos... e... sou militante aqui das ações da União Popular de Mulheres... sou art/...principalmente envolvido aí dentro das ações de resistência cultural dentro do (centro) do Solano Trindade... ligado aí às ações da economia solidária... ao banco comunitário... e... nasci dia 31 de janeiro de $89 . .$.

E: eh... então... a primeira pergunta que eu gostaria de fazer é... se você é familiar com o conceito de emancipação ... e o que isso significa para você?

A: acho que é um tema muito falado assim quando... quando você... quando você tem menos de dezoito anos é um tema que é muito falado né... assim, se você é independente... se emancipar... e... sem perceber você vai vendo que você já está sendo... sem perceber você já está trabalhando para essa... emancipação assim pelo menos na periferia eu desde muito cedo assim já me vi como chefe de família assim da minha casa né eu já tive que achar formas de gerar renda para minha família desde muito cedo... e... a questão da emancipação da periferia sempre tá ligado a questões econômicas... sempre está ligado à questão de superação de... de algumas... de alguma violência social... que no caso essa violência social está retratada em você... é:... não estar morando na beira do córrego... né... de você transformar sua casa de barraco numa casa de/de... de madeira numa casa de bloco... de você não ter telha mas de você ter uma... uma laje... tá ligado? porque em cima dessa laje você pode fazer outra coisa... então esse conceito da emancipação para mim sempre:... sempre:... girou em volta desse... desse... dessas superações dessas violências sociais tá ligado?...

E: você se considera uma pessoa independente?

A: ô independente eu não sei assim porque::... a gente vem com a nossa caminhada com nosso percurso a gente:... acaba tendo:: a colaboração de tanta gente né? então você não sabe se você está ar/ se você está totalmente independente né? porque se você vai morar numa casa com alguém você tá dividindo com alguém ... se você:... você precisa de amor... você precisa dar amor... você precisa... é::... comER... você faz a comida para o outro comer... ou alguém faz para você comer... então é muito:... subjetivo essa ideia da independência né?... eu vejo que:... é:... hoje eu consigo ir / é:... hoj/hoje eu consigo ter independência na mobilidade urbana... hoje eu consigo ir até o centro de São Paulo... hoje eu consigo ir para outros Estados... posso:... po/ quebrei as barreiras da minha::... da minha mente assim nessa questão da independência entendeu?... de fazer que essa comunidade possa ser uma comunidade que receba pessoas de vários lugares do mundo... né?... então esse é um processo de independência que para mim é... bastante in/ interessante assim que eu sinto que eu tenho né?... mas eu acho que a gente depende sim de muita gente para:... sabe? sobreviver assim um com o outro...

E: e::.... você se lembra da primeira coisa que você fez... no caminho de se tornar independente?... um acontecimento uma...

A: put/ a primeira coisa?... a:... eu não sei... acho que::... é::... faz dois anos que eu estou morando com a minha companheira né? que é a Fernanda... e::... foi s/ realmente um momento muito:: compli/ bom e ao mesmo tempo complicado assim... porque:... meu irmão faleceu né?... vítima::... de um confronto com a polícia militar... e aí ele... é::... a polícia matou ele... e::... e eu não queria voltar para essa minha casa que eu estava morando que ele morava entendeu? porque tudo lemBRAva... tinha uma... aí eu fiquei morando na casa de amigos um tempo... fiquei morando na casa de amigos um tempo... e aí depois a gente alugou a casa que a gente está morando até hoje assim então... então (não) faz muito tempo... faz... acho que a primeira vez que senti assim que/ e a minha mãe ela também foi morar em outro lugar assim ela foi morar 
no litoral sul... na ilha comprida... então ela foi morar lá... e::... realmente ela abandonou tudo/ ela abandonou a casa toda mobiliada entendeu?... bagulho que chocou ela demais assim e::.... e ela foi morar em outro lugar né?... ((uma pessoa entra na sala)) -- você vai pegar alguma coisa? pode pegar... (...) -- e::.... então foi um momento meio complicado assim da gente poder se::... de ligar no que a gente estava fazendo e::... e aí eu fiquei moran/ eu fiquei morando na casa de amigos um tempo entendeu?... depois a gente alugou essa casa que a gente está morando aqui agora... e::... então acho que eu estou sentindo ainda esse::... esse gosto... tou sentindo ainda esse::... como que é conviver com essa/ como que é viver entendeu?... nesse lance da independência... mas de uma maneira que a gente não queria ter vivido mas teve que conviver entendeu?... é um momento que::... que foi duro para caramba e tá sendo até hoje né?... que foi há dois anos... faz fazer três anos agora no carnaval mas que a gente está vivendo ele assim...então vo/ (essa) foi uma das primeiras coisas com vinte e quatro anos está acontecendo agora... estava sentindo isso assim né?... todo mês estar pagando aluguel estar fazendo compras... estar::... estar atento às contas tá ligado? o dia que você vai numa balada e você gasta um pouco mais puta na semana vai faltar para condução... vai faltar para um / uma mistura tá ligado? então é... isso assim

E: é::... que atitude você faz no seu dia-a-dia para se manter independente?

A: a gente cria sistemas em nosso favor entendeu?... se eu estou farto de um sistema de violência e opressão eu vou criar um sistema que é essa casa que é um sistema de amor e paz tá ligado?...

E: Essa casa aqui?

A: é:: essa casa e mais quatro casas na comunidade então se eu estou insatisfeito com o sistema capitalista e eu quero construir uma economia que de fato me representa... há quatro anos a gente desenvolve um banco comunitário... se eu quero dar mais visibilidade e eu quero que a minha comunidade ao mesmo tempo que ela assiste o Faustão ela possa também assistir um sarau... que ela possa assistir uma peça de teatro da quebrada... que ela possa ver um cinema... que ela possa ver um... um teatro um/uma dança contemporânea isso tudo são coisas que tem hoje na nossa periferia né? a gente está ligado à agência Solano Trindade né?... então são atitudes que me mantem independente de vários sistemas é::... que hoje estão aí na no sociedade e que deixa a gente descontente entendeu? deixa a gente dependente tá ligado? então hoje eu sinto que eu articulo a minha independência econômica né? comprando no meu bairro fortalecendo o meu bairro... entendeu? é:... ao mesmo tempo que eu preciso dos meios de produção eu preciso compreender também... o::..... como que a economia estabelece na vida das pessoas... e a gente tá tendo uma visão incrível estamos aí há:: há cinco anos desenvolvendo o banco União Sampaio... acompanhando os empreendedores aí que que vem aqui pegar os empréstimos né para as donas de casa... e a gente vê o como a nossa comunidade... se a gente fechar alguns gargalos ela/eu... todas as comunidades elas não são pobres elas são empobrecidas à medida que a riqueza delas vão para outros lugares... então a gente vai criando uns sistemas sabe? se eu estou insatisfeito com a política que::... que hoje estabelece... ô a gente vem criando aí percursos em defesa da diversidade cultural tá ligado? que são encontros entre a sociedade civil e o poder público... então essas são as minhas ações do dia-a-dia tudo isso que eu falei agora é uma é::... são ações que todo dia eu trabalho um pouquinho um pouquinho delas né?... um pouquinho a gente trabalha na agência um pouquinho a gente está falando ali do banco uma outra hora a gente está participando ali de uma:: manifestação ali numa... no Taboão da Serra... então:... acho que o meu dia-a-dia hoje ele está todo tomado conta por isso entendeu? hoje: (ele)... só faço isso... mano... desde a hora que eu levanto desde a hora que eu vou dormir... meu tempo está dedicado todo a isso entendeu? totalmente dedicado a isso assim é... desde a hora que a gente acorda desde a hora que a gente vai dormir nosso tempo está focado nessas... nessa maneiras de:: de estar independente de alguns sistemas tá ligado?

E: e:... existe alguma pessoa que: você acha no meio da sua vida te ajudou a: se emanciPAr ou...? A: Ah: tenho muito amigos assim que me inspiraram né? acho que como a gente vive uma cultura muito::... muito das quebrada muito das ruas tá ligado? muito do escuro muito da 
margem... a gente vai aprendendo muito com cada pessoa que vai passando na nossa vida assim né... então:: então eu... efetivamente assim há cinco anos que eu gero a minha própria renda tá ligado? Então:: e quem me inspirou muito disso foi tipo vendo: o GamÃO que é o cara que grafita aí toda quebrada grafita essa:... grafitou essa sala... é o cara que: me inspirou a ser independente ((telefone tocando)) por conta da: trajetória dele o LuAN do livro mandabusca o Solano Trindade \{oi... isso... é:... eu mesmo (...)\}

E: você estava falando:... das pessoas que te inspiraram...

A: É::... o Luan... o Luan né?... um cara que:... que vi:ve aí né? que vive dos sarAUs das poeSlas e dos Livros que ele próprio comercializa entendeu? inclusive tem livro dele aí na:: na loja né então::... pessoas assim que me inspiraram né que:... a própria minha mãe também que foi uma pessoas que: nunca parou em trabalho nenhum mas... s / nunca deixou faltar nada em casa entendeu? e::... muitos:... e::... muitas referências da cultura periférica assim né que a gente:: que a gente:: vai conhecendo né, graças a deus a gente é novo assim e a gente tem um respeito muito grande por essas pessoas assim que têm uma caminhada que... que já fizeram várias coisas... uma já teve bar outra já teve: / já saiu andando pelo Brasil tá ligado? e elas foram ganhando a vida delas assim né? então é isso né?... são as pessoas do meu dia-a-dia que me inspiraram...

E: é... com a questão do: do: ah... preconceito racial... você:... já / você sente que isso é um:... empecilho para: / alguma pessoa se tornar independente ou é uma::... coisa que... / que não faz tanta diferença?

A: ah mano eu acho que não há:... no modelo econômico vigente no Brasil hoje não há/ não há desenvolvimento sem racismo entendeu?... para ter o desenvolvimento tem que ter o racismo tá ligado?... o racismo institucional... né? o racismo:: racismo ambiental... porque que os preto está sempre do lado das encosta... porque que os preto está sempre na beira do rio isso é racismo amBIENTAL mano e a galera que tem uma moeda está sempre nos que a gente / quando a gente chegou né? nos lugares que são aí... legais enfim ou saudáveis para viver tá ligado? então:... eu vejo que o sistema vigente hoje aí é um sistema que oprime um sistema que você tem que estar com o cabelo cortado para entrar na empresa você tem que... não pode entrar de black não pode: de rasta tá ligado? não pode falar Gíria né então (são) / é um sistema que realmente: complica né mano? -- deixa eu atender aqui rapidinho -- Alô (...)

A: e até a gente: pensando nesse sistema aí... sistema que: né? que não inCLUI o sistema que: só: que só exclui né? é um sistema onde você tem que: você vale o que tem né? muito hoje / hoje: hoje aí:... você vale o que tem muitas vezes... você tem que ter um carro / você tem que ter uma roupa assim / estar se vestindo assim que a gente criou esse sistema nosso aqui de:... de empregabilidade aonde a gente recebe as pessoas a partir do que elas são não do que elas / não do que elas tem respeitando cada uma e:... e::... e viabilizando::: que elas possam viver daquilo que elas estão fazendo... que é arte cultura... o... trabalhar no social tá ligado?... é:: trabalhar na sua comunidade... sabe? isso é uma vitória você poder trabalhar na sua comunidade coisa que: né?::... a ideia do sistema vigente é você pegar um busão aqui e trampar lá do outro lado... né? é você pegar um busão lotado aqui descer lá do outro lado tramPAR lá tá ligado? depois você volta à noite para casa... aí vai jantar... vai comer vai ver nove:la tá ligado? tipo:: um sistema que:: esse des / é desse desenvolvimento que eu estou falando... entendeu?... é um desenvolvimento que para nós a gente viu que não era:... o caminho entendeu?... é um sistema que a gente falou que... que estava bom.. ãhn... os nossos pais já tinham sofrido muito com isso os nossos antepassados já sofreram MUlto com esse sistema e:: o que eles lutaram já é o suficiente para a gente poder se manter tá ligado? é isso que eu penso mano... o que que os caras já lutaram... quem já sofreu... quem sofreu na ditadura... quem sofreu antes da ditadura... tá ligado... já sofreu demais para a gente poder se manter tá ligado? para a gente poder... sabe mano?... é... então o:: existe sim esse racismo né? ele existe ele está nas instituições entendeu? ano passado foi um ano que eu... que eu estive muito em Brasília tá ligado?... é:...ocupando os espaços lá em Brasília... e a gente percebe o jeito que o cara te trata no hotel o jeito que o cara 
te trata no lugar que:... tá ligado?... só (que) e voCÊ / você é no mesmo LUGAR que ele entendeu?... só que ele se incomoda de te ver ali... ele não quer te atender cara... tá ligado? a gente foi lá na conferência da igualdade racial a gente foi na conferência nacional de cultura teve gente que se:: recusou a atender pessoas que eram de cor negra... no hotel elas falaram que não iam atender... entendeu?... complicado mano?... entendeu... então como é que você quer... você quer instigar a democracia se existe esse racismo nas pessoas tá ligado? você tinha que ver a comida lá estava fria entendeu? diferente mano... sabe? então é:... é... você vê que isso está no / nas pessoas / na maneira de se tratar entendeu?... e é uma coisa que a gente sente é uma coisa que a gente vê... está sutil... né: é muito sutil... entendeu?... então a gente combate tudo isso com alegria com cultura com com poesia tá ligado?... com trabalho duro todo dia aqui ó trabalhando você vim aqui ó... durante um ano direto você sempre vai encontrar essa casa aberta com pessoas aqui trabalhando todo dia um pouquinho para garantir essa: essas conquistas que já tivemos até agora... entendeu? então... de fato eu só quero que isso que cresça que cresça e que possa abarcar essas pessoas sequeladas do sistema do trabalho aí... entendeu? porque hoje a gente vem / o que a gente vem fazendo hoje é recebendo muita gente do mercado convencional para trabalhar com a gente né? a gente tem um... um vendedor da:: de uma marca de carro entendeu?... que ele vende carro hoje ele está aqui com a gente para ele trabalhar as venda dos: shows entendeu? as venda do / do / do:.. projeto... entendeu? só que para ele migrar desse sistema para esse sistema não foi c / fácil entendeu?... a gente trabalha em autogestão lá ele coloca o dedão entendeu? aqui a gente trabalha com autogestão as pessoas tem problema em trabalhar com autogestão... né que não tem patrão mas às vezes tem responsabilidades... né?... o cara se sente solto... você tem que pegar e falar assim: "ó mano não tem nada solto aqui você só não está batendo cartão mas... tem essa / essa responsa" e a gente vem migrando essas pessoas para esse::... que respeita elas se ela é gorda se ela é magra se ela é negra se ela é amarela se ela... sabe? é:... isso é uma coisa que eu valorizo muito assim no nosso dia-a-dia

E: é:... pensando assim na:... na sua vida você diria que no seu atual estado você... é... está se emancipando... já se emancipou ou ainda vai se emancipar?

A: ah mano eu acho que eu vou estar me emancipando sempre... tá ligado? acho que sempre eu vou viver uma etapa diferente da minha vida assim eu... agora estou passando por esse momento... né? que::... com certeza esse ano agora dá uma:... reestabelecida de fato... entendeu?... quando isso se estabilizar eu vou entrar em uma outra fase que eu vou precisar de pessoas para me ajudar nessa fase entendeu?... então acho que sempre eu vou estar (nessa) / me emancipando sempre eu vou estar buscando independência... e a gente está vendo que o melhor caminho de buscar isso é estar... junto com as pessoas que... com os mestres né?... com os senhores com as senhoras... né?... que querem também legitimar a força dos jovens e apostam na juventude como continuidade da luta entendeu?... então acho que eu estou me emancipando ainda e eu... quero sempre estar me / me emancipando entendeu?... até:... quando eu estiver... bem velhinho mesmo me emancipando enquanto: velho entendeu?... 


\section{ENTREVISTA FEITA COM C. S., 20 ANOS, MULHER, NO DIA 18 DE MARÇO DE 2014}

E: é:... antes de começar... eu gostaria que você:... falasse seu nome... é:... sua idade... e:... sua profissão... se você... tem uma profissão

C: ah... já posso falar?...

E: pode

C: é... então... meu nome é C... eu tenho 20 anos... e minha profissão... é música... só isso... e agora?... que mais?...

E: tá... então eu vou começar a fazer as perguntas... aí vo/ qualquer coisa que vo/ se você quiser a gente para um pouco... dá uma... podemos... é:... IR fazendo...

C: uhum

E: a primeira pergunta é a seguinte: você se considera uma pessoa independente?

C: $\operatorname{sim}$

E: por que?

C: porque eu não... sei lá... não dependo de ninguém?... ah... sei lá... eu gosto de fazer as coisas tudo sozinha... é isso... deixa eu ver... que mais?... é isso... é isso

E: você lembra da primeira coisa que você fez na sua vida/ QUAL foi a primeira coisa que você fez na sua vida para se tornar independente?

C: primeira coisa?...

E: é...

C: hum... sair de casa... sair de casa assim ó... comecei a andar sozinha...

E: de ônibus?...

C: andando de Ônibus também...

E: a pé pelo bairro:...

C: a pé pelo bairro também...

E: com quantos anos você começou a...

C: com... acho que uns quinze anos... quinze anos...

E: sozinha... sem::... sem irmã sem...?

C: sozinha... sem ninguém...

E: e:... qual é a coisa mais recente assim, nos últimos dias semanas meses é:... qual a/ tem alguma coisa que você lembra que você fez que:... teve um pouco essa coisa de se tornar indepenDENte...?

C: que eu fiz sozinha né?...

E: é...

C: é... deixa eu ver... que eu fiz... foi... ir para um campeonato... campeonato de música sozinha assim com o povo... sabe?... que eu me lembre... foi isso...

E: você::.... era só/ era um Sólo? você cantava sozinha? ou tinha... outros músicos?...

C: não eu fui assim é... com todo mundo do meu grupo assim... sozinha assim sabe?... minha mãe não precisou ir... né?...

E: ah sim...

C: tipo: eu fui in-de-pen-den-te... sozinha... eu e o povo

E: ah sim... [sem a] sua família

C: isso... sem minha família...

E: legal... é::... para você... o que significa ser uma pessoa independente? que que é... ser uma pessoa independente?

C: ah... primeiro acho que é... peSSOa:... responsável?... para falar a verdade eu não:... ah eu não sei... sei lá eu acho que:... fazer as coisas tudo:... tudo sozinha assim sabe?... não precisa de ninguém... para poder... te ajudar... ó eu/ na minha opinião acho que é isso... precisa:... de ajuda assim... (para) ser independente assim sabe?

E: sei

C: para eu ir... sozinha nos lugares... conhecer coisas novas... sozinha também...

E: sei 
C: na minha opinião é isso...

E: legal... é::... você se considera uma pessoa independente uma pessoa que está se tornando independente ou uma pessoa que ainda vai se tornar independente? dentro da sua vida assim...

C: ah:... eu se torno/ eu sou/ acho que eu se tornei uma pessoa independente né?... eu acho que é a palavra certa... é... que mais?...

E: a::... o que você faz... para se manter independente?

C: é:...eu... eu trabalho... eu estudo... e cuido de mim mesma...

E: o que você faz para cuidar de si mesma?

C: o que eu faço para cuidar de mim MESma?...

E: é... por exemplo...

C: ah... eu trabalho para cuidar de mim mesma... trabalho... é isso eu trabalho para cuidar de mim mesma...

E: mas assim.. é um trabalho que você faz na rua é um trabalho que você faz em CAsa?...

C: trabalho que eu faço na rua

E: com a música

C: não... com a música não... é:... é um trabalho de roupa

E: de roupa?

C: é... de vender roupa...

E: numa loja?

C: é numa loja mas tem que ficar na rua sabe?...

E: ah tá...

C: aí... eu trabalho com isso e:... eu cuido de mim mesma... ((risos))

E: legal

C: que mais?

E: e::... existe uma pessoa que foi especial no seu caminho de se tornar independente? / para ser uma pessoa emanciPAda... na sua vida? ... ou pode ser mais de uma pessoa também...

C: que eu conheci agora não né?...

E: tanto faz... pode ter conhecido agora pode ter conhecido há muito tempo...

C: é: deixa eu ver... ai... conheci sim uma pess/ conheço sim uma pessoa... é... tem que falar o nome dessa pessoa?

E: não precisa dizer o nome... mas falAR... quem era... por que...

C: por que?... porque::... porque eu não sei... ((risos))

E: é difícil explicar?...

C: sei lá... é difícil explicar para mim... é difícil...

E: uma pessoa que você admirou... assim que você se inspirava nessa pessoa?...

C: é:... essa pessoa foi... é:... minha amiga... uma amiga minha... que eu me inspirei nela... e com ela fui... muito independente também... eu aprendi a ser independente... é... eu acho que é isso...

E: legal e ela:: é sua amiga até HOje?

C: ela não é mais minha amiga

E: mas mesmo assim você seguiu...

C: eu segui o caminho... é isso... agora... mais alguma coisa que eu possa...

E: é:... como você se sente... sendo uma pessoa indepen/ é:... autônoma? como você sente?

C: eu me sinto:.... muito... muito feliz... muito feliz... muito além... é isso aí...

E: você teve algum momento da sua vida que você:... é: sentiu que: a sua vida independente não estava acontecendo... que tinha alguma coisa que impedia que você pudesse seguir... o seu caminho?... que momento foi esse?...

C: momento... quando eu... é eu há um tempo estou/ que eu parei... de estudar...

E: você parou de estudar? 
C: é... eu acho que foi isso né... que eu parei... de estudar... fiquei meio assim... mas depois... continuei seguindo...

E: como é que foi isso? quem tomou essa decisão?

C: de parar de estudar?... eu parei de estudar... é eu que tomei essa decisão de parar de estudar... não foi fácil mas eu tive que parar de estudar...

E: por que?

C: por que?... tem que contar isso?...

E: conta se quiser...

C: eu parei de estudar... por causa que estava tendo muito:... muita/muita bagunça sabe? aí eu parei de estudar... muita bagunça assim na escola...

E: na escola?

C: que eu parei de/ eu parei no segundo colegial...quando eu parei de estudar... por causa das bagunças do povo...né?...

E: mas era porque tinha alguém te:.. bagunçando especificamente com você ou era::...

bagunça da sala em geral... tinha porque às vezes acontece...

C: das duas coisas... de mim e da... da sala também... uma bagunça (estava difícil) de estudar

E: mas era dos alunos mais...

C: é: coisa dos alunos mais... dos alunos... não tinha ordem naquela escola

E: e a escola também... a organização também::...?

C: não era boa... aí depois... eu parei mas depois eu fiquei com a maior vontade de voltar... eu pretendo voltar um dia... é isso...

$\mathrm{E}:$ faz quantos anos que isso aconteceu?

C: já faz dois anos atrás... é... dois anos atrás...

E: você: já foi vítima de preconceito? racial ou algum outro tipo de violência? por ser mulher...

C: é... ah... de/ de olho também... porque eu não enxergava sabe?... o olho era torto também... e de:: como é que fala?... ah: e de bulying também né? Esse bulying na escola... esses negócios...

E: sei...

C: mas passou...

E: você acha que isso pode ter atrapalhado você para se tornar uma pessoa independente?

C: muito...

E: pensando... agora... nas coisas que você::... faz né?... sua profissão... e os seus... interesses né? pessoais... é... qual/ qual o momento mais intenso... que você sente que teve uma::... um desenvolvimento maior da sua/ do seu / da sua independência/ da sua emancipação?...

C: para mim foi a banda...

E: a banda?

C: foi a banda me fez eu inspiRAR... muito assim sabe?... para mim crescer... na vida... (para $\mathrm{mim}$ ) foi a banda... por isso que a banda:.../ depois que eu entrei na banda aí tudo:... tudo cresceu...

E: é né?

C: tudo cresceu... até a inspiração de estudar

E: legal...

C: que mais?...

E: tem mais alguma coisa que você gostaria de comentAR... a respeito...

C: a respeito a que?...

E: é... dentro: dessa temática do:: se tornar independente... é:.. se você... pretende sair de

CAsa... ou não... a coisa do... é: seu companheiro... se você tem/ quer falar...

C: eu pretendo... por enquanto eu pretendo ficar lá na casa da minha mãe... onde eu estou lá... depois... seguir a minha vida adiante... né?... porque:: ser independente é muito imporTANte... na nossa vida... é isso

E: mas você acha que:... vai sair um dia ou você acha que:: você pode continuar lá?

C: lá eu acho que eu posso continuar... 
E: pode?...

C: posso... eu posso continuar lá mas... um dia eu sei que eu vou ter que sair... que sair... e viver a minha vida né?... como uma pessoa independente... é isso...

E: eu acho que está bom...

E: eu queria saber a respeito da:... é que eu estou vendo que você está grá::vida né?... queria saber como é que:::... isso daí está:... é::.... que que está acontecendo/ que está acontecendo na sua vida de... para poder... de ser independente você acha que... isso é uma coisa que ajuda uma coisa que dificulta... como é que é?

C: ah... isso é uma coisa... que só as mulheres grávidas sentem... uma coisa muito / muito bom... de se viver... e de se aprender né porque::... a partir do momento que uma pessoa/uma mulher fica grávida né?... ela sente muitas coisas... ela sente ela sente ela pode estar... triste... ao mesmo tempo ela pode estar feliz ao mesmo tempo ela pode estar... sorrindo... muitas coisas...

E: é o seu primeiro... filho?

C: é... meu primeiro filho... com muito:: é uma coisa muito::... ah eu não sei como dizer sabe? é uma coisa muito forte... ((risos)) é:... eu ia te falar mais alguma coisa aí... ((pausa prolongada)) você não está pensando em alguma coisa assim... para me...

E: eu?... estou

C: você já não sabe o que falar não é?...

E: como você está:... com o seu companheiro? ele está:: ele também está feliz?... ele está próximo?...

C: ele também está feliz... está muito próximo... mas ele... para ele... é muito emocionante... ele... não é o primeiro filho esse já é o terceiro dele... mas é... tudo homem que ele tem tendência a ter homem... e daí... para ele é muito emocionante porque:: a partir do momento... quando: quando fica/ quando nasce uma criança... é:... aparece os traços né?... se é homem ou mulher... (então) umas coisas assim... mas você entendeu o que eu quis dizer né?... então... é isso... mas é interessante também da parte que a mulher sente né? Que: que ela sente... que eu sinto/ a criança sente: tudo que eu sinto... entendeu? tipo assim... se eu estiver triste a criança vai estar triste... se eu estiver feliz a criança vai estar feliz... é... é muitas coisas assim sabe?... e também:... ai... sei lá... tem muitas coisas assim sabe? Para descrever para falar... você quer fazer mais algumas pergunta? ((risos))

E: acho que é isso.

C: é isso?... ah então tá bom... 


\section{ENTREVISTA COM J. S. 23 ANOS, HOMEM, DIA 06 DE JUNHO DE 2014}

E: é:: vou pedir para você: me... dizer seu nome... idade... nome completo idade J: meu nome é J. S... tenho 23 anos... trabalho como: educador social... sou... capoeirista... esportista... humm:... sonhador...

E: legal... é::... vamos começar então... você se considera uma pessoa independente?

$\mathrm{J}$ sim

E: por que?

J: acho que:... a independência não vem do momento que:... você sai da sua casa / eu acho que ela sai do momento em que você começa a libertar sua mente para as coisas novas... quando você deixa de... de sonhar o sonho de outras pessoas e querer sonhar o seu sonho e ir em busca dele... acho que é o que te torna independente... não o estar dentro da casa da mãe, ou o estar dentro da casa do pai ou do tio $\{E$ : ahn $\{\mathrm{J}$ : se tornar independente é poder sonhar... tentar realizar seus sonhos... os SEUS sonhos não os sonhos que seus pais querem que você sonhe

E: legal... é:... bom você já respondeu um pouco: mas... uma pergunta um pouco mais específica o que você busca... é: ou buscava quando você: estava começando a procurar mais / ter mais liberdade e autonomia na sua vida?

J: primeiro... acho que o que eu busCAva era: eu queria mudar a história da minha família porque eu venho de uma família que ela: vem de classe baixa e:: que nenhum dos meus familiares cursaram a faculdade ainda né?... eu sou o primeiro a entrar em uma faculdade... e:: falei... bom... quero: ser o primeiro quero... um dia entrar... porque: ou / outras pessoas da minha família e outros... tipo o meu filho ou o filho da minha irmã... os meus sobrinhos... possam estar dentro de uma faculdade ou estar querendo alguma coisa diferente do que aquela:... do que a vida que meus pais tiveram...

E: legal... é:... você se tornou independente porque quis?

$\mathrm{J}$ : sim... eu me tornei independente porque quis porque eu queria mudar... algo mais além do que minha família já era... tinha para oferecer... apesar de não ter sido uma coisa tão ruim o que minha família tem para oferecer mas assim... eu queria mais... acho que até um pouco ambicioso... (sem bem) dizer

E: mas você sentiu que:... teve, por assim dizer... uma:: alguma: pressão de alguém da sua família ou de alguma: / ou de algum outra é:... pessoa para que você é:... se:... emanciPAsse ou foi uma coisa que... veio de você mesmo?

J: é que: acho que a emancipação tem / tem dois jeitos tem o lado da pressão e tem o lado natural né? que nem / que nem... a gente fala que os pais sempre cobram que a gente entre numa faculDAde ou... arrume emprego... arrume uma mulher... ou:... ou homem... que saia de casa vá morar com ela que comece a criar sua própria família ou: viver sua vida... mas também tem aquele de: / aquele tipo de: você vai fazendo as coisas e de repente você vê que você está... saindo de casa... está: está: fazendo uma faculdade por conta própria está pagando as suas contas... está começando a construir seus sonhos... tornar realidade... e é isso que / você vai indo... eu acho que por mim... pelo meu jeito acho que veio mais do: / do lance de deixar as coisas acontecerem... meus pais nunca cobraram muito de mim assim ah "você precisa sair de casa você precisa... trabalhar você precisa entrar em uma faculdade" mas: foi vindo... sabe? \{ $\mathrm{E}:$ uhn $\{\mathrm{J}$ : (teve) outras pessoas me incentivando... a querer mais coisas...

E: legal e essas outras pessoas que assim... te incentivaram... é: tinha alguma pessoa que... é: importante assim para te incentivar? \{J: sim... é \{ que você gostaria de: mencionar? não precisa falar o nome...

$\mathrm{J}$ : sim... sim existe uma pessoa sim hoje eu trabalho com / com ela eu tenho muito orgulho de: / de: ser funcionário de:le... e para mim... (eu acho) o exemplo dele de / como profissional de... pessoa acho que me fez... motivar o que eu faço... e ir mais além do que: / do que eu posso fazer... \{E: hum E: é:... você acredita que a:: a sociedade favorece os jovens a ser tornar independentes? 
J: a sociedade... não... acho que não favorece... TÃO assim... porque... de / acho que / é uma pergunta meio re / não sei se é retórica... meio contraditório porque ao mesmo tempo que / que tem aquele lance dos pais cobrarem dos jovens quererem ser emancipados... depois tem um lado meio paternalístico... porque você tem que estar perto da família / porque você tem que / ah porque você tem que ajuDAR... porque você tem que dá / estar mais focado familiarmente... então é uma coisa mais tipo... é meio estranho... dizer... \{E: hum \{J: mas eu acho que a sociedade não cobra tanto assim dos jovens... \{E: tá... \{J: é estranho sobre o:: ... é que cobra e não cobra... de um lado cobra que você tenha: a emancipação de outro lado... é: você tem que estar mais junto do que o: / da onde você nasceu das suas raízes... \{E: a sociedade cobra que você esteja mais $\{\mathrm{J}$ : sim... é que acho que cobra sim cobra \{E: tá... E: agora eu gostaria que você descrevesse assim como: foi que você né?... se tornou assim... emanciPAdo... uma pessoa independente... como foi esse processo? pode ser tanto na questão do trabalho quanto de relacionamentos quanto de religião se você tiver... ou não... é... pode falar de qualquer um desses aspectos...

J: eu acho que:... eu... quando eu decidi me tornar emancipado foi quando eu cheguei / quando eu cons / eu fiz meu primeiro vestibular e me f / e saiu o resultado positivo e: meus pais falaram que (eu) não podia pagar a condução para mim, não ía poder cursar a faculdade aí eu falei eu não posso cobrar dos meus pais isso... eles me deram uma educação boa... me deram um âmbito familiar muito: / muito bom... nunca deixaram eu passar fome... depois pelo outro lado eu estava passando em um dos vestibulares mais concorridos e eu queria cursar de qualquer jeito... e meu pai falou "pô não tem como a família bancar isso" aí foi por isso que eu decidi mesmo ser emancipado... eu queria começar a me é:... a me bancar... financeiramente e queria ajudar mais meus pais... \{E: legal / legal... \{J: aí daí / aí daí veio / veio vários rompiment / vários / várias / várias barreiras que eu quebrei de começar a sonhar com os próprios sonhos começar a estipular metas que eu queria ir atrás... busCAR novos caminhos... sair da zona de confort / da zona de conforto... \{E: uhum

E: legal... é:: você se sente bem... sendo uma pessoa... autônoma?

J: nossa ótimo assim... não por conta de não precisar de ninguém assim... eu pago as minhas contas eu sonho os meus sonhos assim... mas você se sente bem quando você vê a / algo: / tipo: que:... alguém / algum outro jovem olha para você e fala "pô... se você conseguiu eu também consigo chegar lá..." então que nem eu trabalho muito com / com / com:... empreendedorismo social essas coisas e com: transformação de vida né?... que eu trabalho bastante com jovens em vulnerabilidade social... tem risco na socieda / tem risco na sociedade... quando um jovem fala "pô você conseguiu mudar sua situação você escolheu... é:... trabalhar como educador... eu te tenho como / como esPElho... é isso que eu sou:... / que sou mais grato assim nem é o salário que eu recebo nem é o:: as contas que eu tenho que / para pagar... os cursos que / que eu consigo bolsa... mas o sorriso do jovem falando "caralho... (eu) também posso conseguir... / também vou mudar minha situação" é o que paga (...) \{E: paga né?

E: legal... é:... dentro desse processo né?... de: aquisi / se tornar independente / emancipado... é: você passou por algum momento difícil?

$\mathrm{J}$ : dentro do processo de ser emancipado passa /...

E: ou você está passando / tem alguma coisa que você gostaria de comentar de / é:: intensidade... de dificuldade...

J: acho que... / agora por enquanto... desde quando eu me falei "não tenho que começar... a me tornar emancipado / tenho que começar... a trilhar o meu caminho... e... reconstruir uma nova história... eu não... cheguei a passar nenhum momento difícil não... mas:: tem / são pequenas coisas no dia assim que / às vezes você fala assim né? pô... será que eu tou (indo) no caminho certo? será que... é: / será que é isso mesmo?... será que trabalhar numa empresa... maior de grande porte seria legal... estaria ganhando bem mas... talvez eu não estaria com esse sorriso... que eu tenho hoje... de todo dia... vim aqui e trampar mas acho que... momentos difícil ainda eu não passei e: e eu... todo dia quando eu levanto da minha cama... 
eu: ... venho trabalhar com... com... com: brilho nos olhos para minimizar isso né? tipo... se vir um dia alguma / (ou) algum momento difícil... eu saber absorver isso e falar ... "hoje me derrubou mas amanhã eu vou estar... firme e forte porque:... estou pronto para enfrentar" E: muito legal... é:... bom... agora vamos entrar um pouco na questão do racismo... se você: é... já foi vítima de racismo... em alguma situação?

J: já... \{E: sim? \{J: sim... quando eu tinha: dez anos de... de idade eu fui inventar de entrar em uma loja de:... que vendia:... brinquedos... eu ia comprar um brinquedo só que eu estava de chinelo... e estava de: / de bermuda camiseta: normal... e: simplesmente o(s):... segurança(s) ele estava no: / no trabalho dele eu não vou falar que... (ele foi) estúpido mas ele:: estava fazendo a função dele ele me pegou pelo braço me tirou fora da loja... falando que eu iria roubar a loja e: nem perguntou se eu tinha dinheiro ou não para pagar o que eu ia comprar ou... porque eu estava lá dentro simplesmente não me ouviu e me tirou fora da loja... mas:... ah são coisas que passam... no mesmo dia eu... fiz a questão de / de ir até em casa trocar de roupa me vestir mais... mais adequadamente entrei na loja... comprei o... o brinquedo o br / o brinquedo que eu estava e: falei: "viu como eu não ia roubar?" porque às vezes a gente aponta muito... o ato que você sofreu mas você não ma / você não fa / você não dá a chance da pessoa que cometeu o ato ver que você não ia fazer: nada... que nem... o cara podia... ele... estava pensando que eu ia roubar lá... mas na verdade eu estava... indo comprar... e depois que eu mostrei para ele que eu ia comprar mesmo ele falou / ele veio pedir desculpas né? E: é: você sente que o racismo: é uma coisa que dificulta.. o processo... das pessoas construírem... as próprias vidas?

J: sim dificulta muito (um) por conta de: / a gente ver... que o jov / ... o jovens... de periferia... não sai do / da periferia para ir para o centro para... para fazer algum curso: por medo de:... pegar bolsa em alguma / em alguma escola particular... para estudar... porque ele sabe como que é né? tipo... se você está dentro de uma escola particular... você é o único bolsista você vai... o pessoal vai ficar te chamando "ah... você é o bolsista... você não s / você n / você não tem dinheiro..." ou até mesmo: o racismo sem querer que a gente fala... que é... você está lá no: no âmbito:... escolar e: de repente... seus amigos começam a discutir "pô... fui para Paris ontem a noite fui para: para Milão não sei que lá..." e você simplesmente ficou em parelheiros ou você ficou no Grajaú ou você ficou em x lugar e:... você fala "puta que o pariu... tinha que ouvir isso..." até é: hum... um certo racismo da sua parte porque os caras foram / foram e você não né? mas: fala "pô" sabe? mas é um racismo sem querer assim que acontece E: é:... você tem alguma história... assim... para contar que seja sua ou de alguma: / algum aluno seu que já:... te relatou? nesse sentido assim?

$\mathrm{J}$ : de racismo?... ah... a gente sabe... que todos os dias milhares de jovens são abordados por por policial por causa de:... por causa da cor ne... \{E: uhum \{J: e por causa de:... de:... dinheiro ou alguma coisa assim né? mas... eu já vi assim cen / uma cena muito: horrível / muito: horrível não tipo... muito: hilária de ver porque:... foi assim... eu estava saindo da comunidade da onde eu moro... e.... do lado estava saindo dois jovens negros... junto com eles dois jovens brancos... e:... a po / a polícia enquadrou... os quatro... mandou os jovens brancos para o lado e continuar andando e os jovens negros ficaram... e os quatro ia para o mesmo lugar os quatro não tinha feito nada... né? a gente vê que só enquadraram porque pensaram que: alguma coisa / tinha alguma de errado

E: é:... tá e ... algum outro tipo de violência... é: que você:... acha que... acontece... não talvez em virtude do racismo mas de outros tipos de exclusão que você gostaria de mencionar? J: ah eu... que nem... eu trabalho em uma organização que trabalha com... com com vários tipos de violência né? desde: violência doméstica a: a violência na rua... a violência na escola... então assim... é uma violência muito grande... o número de agressões... em crianças... que nem... a a acho que uma das maiores violências que: que eu vejo assim que me: / que me deixam muito chocado é o:... abandono da família com: com crianças né? a gente pega muitos jovens... tipo na cracolândia assim... e aonde está a família aonde esta... às vezes nem é abandono às vezes é a criança que foge mesmo mas mesmo assim é um tipo de abandono... eu 
acho isso uma violência muito grande assim... porque:... criança não tem que ficar na rua... pipando pedra... criança... tem que brincar... criança tem que:... ser feliz tem que...

E: você acha que: você acha que esse tipo de / de violência... doméstica que você mencionou... é:... no trabalho... ou... de outro tipo de: / de violência é: também: tem uma: / tem um impacto grande sobre: a capacidade das pessoas... se tornarem independentes? $\mathrm{J}$ : sim tem muito grande porque: hum... sofrer uma: / sofrer violência / sofrer qualquer tipo de violência te causa... distúrbios mentais né? assim... tem gente que fica:... anos fazendo psicoterapia para poder:... minimizar alguma coisa para: romper: algumas barreiras porque quando a gente sofre uma violência a gente cria um muro né?... muito gigante desde uma violência de racismo a violência doméstica a um abuso sexual... dentro da... da família ou fora da família ou na rua ou em qualquer espaço é um muro que você constrói que para você derrubar ele é anos... e:: e é difícil né?

E: é dentro do bairro que você: mora / que você vive você: já ouviu alguma história de: / de / desse tipo de violência? Você já teve acesso / ou às vezes com alguma criança que você já trabalh / que você traBAlha com um jo:vem... amigo...

J: ah hum... eu tenho / eu tenho:... vários casos de violência que: que... que eu a / que a...tende na instituição que eu trabalho... desde:... abuso sexual desde: agressão familiar $\{\mathrm{E}$ : uhum... \{J: então muito:... muito grande assim... os casos... mas... ao mesmo tempo também a gente: fica:... um pouco feliz que não tenha: tantos casos assim tão generalizado de / de: agressão de criança... poderia ser pior né? sociedade está chegando em um ponto que: você não... / daqui a um tempo eu acho que você não vai controlar mais... se as pessoas não começarem a mudar...

E: legal... é:... tem mais alguma coisa que você gostaria de acrescentar?... você acha que: sobre a sua história sobre a sua infância sobre a sua:... juventude...

J: eu acho que não... eu acho que:... a mesma coisa que:... (...) dá porque:... a maioria dos jovens:... querem mudar... a sua situação sabe?... querem... sair da sua zona de conforto mas... falta um pouco de oportunidade não só oportunidade de:... falar "ó está aqui o: / o emprego está aqui a vaga... o bolsista ou está aqui o... a vaga na universidade" mas sim a oportunidade de mudar com um incentivo falar tipo: "pô vai lá você pode fazer mesmo" ou... "você não está conseguindo?" vamos lá nós dois e:... a gente começa a caminhar e:... depois você segue sozinho \{E: uhum \{J: é essa oportunidade que eu falo porque: quando... que nem... eu tenho uma frase que fica muito na minha mente que: não há / não basta você só dar o peixe... para a pessoa... você tem que ensinar a pessoa a pescar o próprio peixe se não e / a: pessoa vai sempre te / querer o: / o peixe se você dar a vara a pessoa vai aprender a pescar E: sobre essa zona de conforto?... é:... o que que... é:... é assim para você essa zona de conforto? existe algum tipo de... comportamento assim que você: identifica?

$\mathrm{J}$ : da zona de conforto?... (deixa eu ver) para mim eu acho que está dentro da zona de conforto é:... não querer a mudança sabe? porque a gen / o: tempo vem... as coisas vem... e se você não for se adaptando... e: e criando a sua própria personalidade dentro dessa / desse tempo... e querendo coisas... para você... você vai continuar... na mesma... no mesmo lugar... para mim isso é a zona de conforto... é que nem um... como eu posso dizer... é que nem um objeto parado no... / parado no lugar a gente sabe (que) se a gente pegar um (e) objeto colocar ali... ele vai ficar sempre ali sabe? mas: se a gente pega um: um: plÃo... quando você joga o pião... e ele começa a rodar... ele vai / ele vai ficar no mesmo lugar... mas ele começa a rodar rodar rodar rodar rodar rodar e ele vai saindo um pouquinho do lugar então é o momento que ele sai de... \{E: uhum $\{\mathrm{J}$ : de vez... para mim acho que isso é um pouco da zona de conforto... continuar estático assim \{E: sei \{J: eu não consi / EU pra / particularmente eu não consigo mais ficar estático falar... eu vou ficar... que nem... eu vou ficar dez anos trabalhando na mesma instituição... ou no mesmo trabalho... ganhando a mesma coisa... querendo os mesmos sonhos eu não:... eu acho que para mim acho que não chega a isso... (eu) tenho que fazer de alguma forma realizar esse sonho... estou querendo ganhar um pouco mais... mas para me manter... não para ser milionário... mas isso... eu tenho que estar movimentando... o / um:: dia eu estou 
aqui / tipo / que nem... eu brinco aqui / eu brinco aqui dentro da instituição que eu trabalho que:... um dia eu dou aula de informática... um dia eu dou aula de: eu dou aula de: inglês... outro dia eu dou: dou aula de grafite... isso é um pouco sair da zona de conforto... eu não estou sempre na mesma oficina na mesma coisa eu estou em vários $\{\mathrm{E}$ : sei... é uma: ... capacidade de transitar né? \{J: é... eu acho que as pessoas têm que querer buscar esse tipo de capacidade de transitar... uhn: não falo transitar assim para mil luGAres mas: vamos sair um pouquinho do / do mundo estático... que nem eu te / eu te falei muito do lance de comunidade de jovens não vim / não sair tanto da comunidade para sair para o centro... essa não ida... do jovem para o centro... impede que o jovem coNHEça... milhões de coisas $\{\mathrm{E}$ : uhum \{J: então ele estaria ainda dentro: da zona de conforto... não que a comunidade seja ruim porque a comunidade tem várias potências... dentro da comunidade tem cultura... dentro da / dentro da comunidade tem emPREgo... tem várias coisas mas o:... o / o que tem na comunidade... não tem no centro... e o que tem no centro... não tem dentro da comunidade... ai as coisas vão um / o que eu falo de transitar é isso... você conseguir ir para um espaço... absorver... e ir para o seu espaço... compartilhar... ou você sair do seu espaço e compartilhar o que você tem lá no outro espaço... aí fica nesse trânsito assim... \{E: uhum \{J: (eu) acho que o que me resume é isso... um pouco isso... eu gos / eu sou bem: pessoa que gosta de transitar por vários espaços... ao mesmo tempo que eu consigo conversar com / com o jovem da comunidade eu consigo conversar com o jovem de: / com o jovem que mora no condomínio ou: ou quando eu estou conversando com o jovem de comunida:de eu consigo conversar com um CEO de alguma empresa famosa... ou eu consigo conversar com o... o trânsito... ficar... giran:do pelas coisas... \{E: uhum... mas... vamos dizer... se tiver por exemplo: um: um: jovem que é:... ótimo professor de capoeira... por exemplo... ele gosta disso e ele fica: VINte anos sendo professor de capoeira... mas ele gosta ele tem um bom desempenho... e: o: o: curso dele... vai bem... você acha que ele está dentro da zona de conforto? \{J: não... ele:... está dentro da zona de conforto porque ele está sempre naquele:... modo estático... mas aí depende... o que que é essa zona de conforto... como que esse professor de capoeira ele se: / locomove com as ou / se / é: como ele conversa com as outras... pessoas porque a gente sabe que: a capoeira é uma / é um esporte é uma dança... ela: pode transformar as pessoas... ela: pode gerar empregos... o que você quiser para as pessoas... para: para outras pessoas... ela pode ser um meio de comunicação... então... é uma zona de conforto que é uma zona muito ampla... assim... vai depender de como que é / de como que está a cabeça de cada pessoa... tipo que nem... se eu ficar vinte anos... dando aula só no mesmo lugar... eu vou estar criando alguns... filhos... para: / para: poder passar minha: meu conhecimento para a geração... mas... se eu tivesse saído desse lugar... e ter deixado um filho meu ali... dando: aula ne / nesse meu lugar... e: / e ido para outro espaço... quantos filhos eu não estaria criando em ou / em outros âmbitos?... ou se meus filhos começassem a sair... da / da / da minha... do meu espa:ço... para outros lugares... quanto mais jovens eu conseguiria impactar... quanto mais de empregos... dentro da capoeira eu conseguiria... arrumar para essas pessoas ou quanto mais finan / de financiadores para que a / $\mathrm{p}$ / capoeira exista / possa: / possa crescer... porque a gente sa:be que a / que a capoeira é um esporte que ela:... dentro do Brasil ela não é tão valorizada assim... \{E: uhum \{J: mas lá fora ela é muito valorizada... que é muito... que eu acho... que eu: acho... um absurdo... sabe... e:... acho que é uma coisa que a gente $\mathrm{n} /$ que não deve: continuar assim... o brasil tem que valorizar... valorizar o que tem de: / de bom... porque a capoeira ela é:... algo bom... algo que transforma... é algo que / que: educa... de fato... e é algo que salva pessoas... que a gente sabe que muitas pessoas já foram sal / foram salvas... do cri:me por (causa da) capoeira... \{E: uhum \{J: ou... as pessoas que: rever / fizeram o caminho reverso... entraram na capoeira e foram para o crime...mas: $\{\mathrm{E}:(($ risos $))\{\mathrm{J}:$ mas... mesmo assim:... é um:... é uma coisa:... para... para se ampliar... sair da zona de conforto é isso... para mim... (ser ampliado que)... o cara pode DAR... vinte anos de aula em um mesmo espaço... ou vinte anos de: de a / está há vinte anos já um / dentro da capoeira... mas é como ele: se conversa com o todo... com / como que... o cara que: que dá capoeira como que ele:... sabe... 
é... é:... sistematizar a metodologia dele para poder um dia ensinar uma pessoa para poder dar en / ah... aula em outro lugar... \{E: u... é: multiplicar... \{J: é: multiplicar... criar multi / é: criar multiplicadores do que ele FAz... para mim eu acho que isso é... / está:... muito bem dito na capoeira... que nem... mestre bimba é isso... ele criou muitos multiplicadores... a capoeira... de angola tambÉM... você vê muita gente que são / assim... muita gente que são multi / tem / tem poucos espaços de capoeira de angola mas:... tem multiplicadores da capoeira... hoje o Brasil está buscando isso... que é a... / é a mesma coisa que o futebol... o futebol você vê milhares de multiplicadores $\{\mathrm{E}$ : uhum $\{\mathrm{J}$ : que um dia a capoeira seja que nem o futebol... de tão valoriza:da tão bem... / que os profissionais da capoeira sejam... Pagos também para / para estar nesse lugares que a gente sabe que... a capoeira é uma paixão... e:... a maioria dos não trab / não estão só dentro da capoeira por dinheiro estão por causa que é uma / que é uma coisa que está no sangue que é uma coisa que / que eles amam / que a gente ama... fazer... isso porque se fosse depender de: dinheiro... a gente sabe que não ia / que não tem... \{E: ... sabe... \{J: engraçado... porque eu tenho essa visão assim... meio \{E:ah não / não é só você ((risos)) 


\section{ENTREVISTA FEITA COM S. M., 28 ANOS, MULHER, FEITA NO DIA 17 DE JULHO DE 2014}

E: é:... bom então vamos começar... por favor, diga o seu nome, idade e estado civil.

S: S... vinte e oito anos (estado) civil solteira

E: é:... como era sua vida quando você era criança?

S: ah era diverti:da... brincava bastante na ru:a... nos meus amigos... aprontava bastante subia em árvore... é:... na escola a escola era na rua de casa então... brincava bastante antes de ir para a / para a escola... tive o meu irmão quando eu tinha quatro anos... foi legal... ter um irmão... acho que:... é isso quer que eu fale mais alguma coisa?... gostava de: de brincar de ir para a escola... minha mãe trabalhava o dia to:do... então... até:: ... até os quatro cinco anos eu ia para a cre:che... de manhã minha mãe deixava... eu e meu irmão na creche e daí da creche eu ia para a escola da escola eu pegava o meu irmão na creche... voltava para casa... para esperar minha mãe chegar... durante a semana... que mais que eu lembro da minha infância?... é isso...

E: está bom... é:... como é o seu dia a dia hoje?... o que você faz normalmente do momento que você aCORda até o momento em que você vai dormir?

S: acordo... acordo... depende entre: seis e meia... sete horas... me arrumo vou traba... / pego o Ônibus... ou carona vou trabalhar... trabalho em uma organização social em Embu das Artes... que atende:... crianças e... jovens de seis... a dezessete anos... cuido da comunicação... sou agente de comunicação... então: lá eu geralmente fico... na frente do computador... escrevendo e recebendo e-mail escrevendo tex:tos... cuidando do... do facebook... das das redes sociais né?... escrevo para o blog... atendo as pessoas que vão lá... faço um pouco de atendimento ao público... atendo teleFOne... participo de reuniões dependendo do dia... escrevo projeto relatório... que mais?... é isso... meu horário de almoço é da uma às duas... e: saio da Acorde... depende muito (de) cinco e meia seis e meia... sete horas... é:... descrição do meu... dia a dia é isso... volto para CAsa regularmente de segunda e quarta... vou para o inglês... faço inglês pertinho de casa uma maravilha... chego em três minutos... e:... só assim... de atividades fechadas eu... tenho inglês... gosto muito de ir ao Sesc que é perto de casa... para comer... ou assistir...teatro show... é isso

E: legal... é::... é dentro da / é: qual é a sua profissão?

S: eu sou formada em relações públicas... comunicação social com habilitação em relações públicas

E: é:... e a sua formação... é: o que você faz hoje?

S: sim... em grande parte sim né?... eu cuido da comunicação institucional... de uma organização social então... muitas das coisas que eu... aprendi na faculdade eu faço hoje... relacionamento com / com assessoria de imprensa... construção de / de: release... essas coisa mais... voltadas à comunicação mesmo eu FAço... acho que: talvez o que tenha de diferente da minha formação... é que RP... muitas vezes é voltada para a comunicação de empresas né? aí eu... trabalho para uma organização social... QUE tem muito da... da linearidade $d$ / da empresa mas que tem outras demandas como atender a comuniDAde como atender... ao público... ajudar os outros setores que / que... apesar de ser setorizado não é TÃO... dividido como num / numa: empresa

E: uhum... é:... tá... então agora a gente falou um pouco sobre o seu traBAlho sua profissão ago:ra queria te perguntar um pouco sobre qual é a sua paixão? a coisa que você gosta de fazer...

S: paixão?... eu sou apaixonada por pessoas... pela: / pela diversidade... das pessoas pelas... peculiaridades... então eu gosto muito de estar com as pessoas gosto muito... de ter amigos... de estar com os meus amigos... e:... eu sou apaixonada pela possibilidade de transformação... no mundo assim... eu como um agente de transformação... eu posso provocar... para que o mundo ou para que o meu entorno seja diferente eu acho que... isso é um... algo que eu gosto e que eu acredito bastante...

E: para você o que é ser jovem? 
S: para mim... juventude não está muito ligado a... / a idade... eu... acho sim que / que um determinado: tempo da nossa história de vida a gente tem uma maior vitalidade uma maior alegria um:... um... um desperTAR para as coisas para fazer as coisas para estar em movimento para mim juventude é isso... ser jovem é isso é:... estar: em movimen:to é provocando algumas situações instigando... e:... acho que uma coisa que: / que eu vejo nos outros jovens e até mesmo em mim... é a teimosia né então... teimosia de de buscar determinadas coisas teimosia de a / de acrediTAR em coisas que:... às vezes em... em outros pontos da vida não não acredito juventude é isso... muito a ver com o pulsar da vida...

E: legal... ah e o que é ser adulto?

S: ((suspiro))... acho que... ANtes... quando eu era... mais nova... eu via a vida adulta de um jeito mais chato assim mais:... mais... organizado talvez mais... cheio de responsabilidades... então... uma coisa mais linear mais rotineira... ser adulto para mim tem relação com com rotina... com... com o igual ((risos))... \{E: uhum $\{\mathrm{S}$ : mas:... agora que eu estou ch / ... que que estou chegando... ESTOU numa fase mais... adulta e ho / e no... TEMpo que a gente vive hoje... que as possibilidades são / são maiores...né?... que o o LEque... de escolhas e:... tem (que estar) mais aBERto... eu vejo a vida adulta... mais como uma consolidação talvez da juventude... dos processos... que eram... mais:... mais no SOnho... ou mais no: / na imaginação eu vejo a vida adulta mais... nesse processo de solidificar ISso... (não)... SOlidificar mas talvez realizAR: algumas coisas...

E: legal... é:... você se considera uma pessoa que faz o que quer?

S: me conside:ro... em partes... porque:... eu gosto muito de trabalhar no terceiro setor... gosto muito de: / de trabalhar com criança e adolescente... GOSto de trabalhar com comunicação que: / que é a formação que eu escolhi justamente... por ter u / um:... um ponto de interrogação... de / de mi / para mim a comunicação é... muito mais alÉM do que:... o forMAL do que o acaDÊmico... mas a comunicação é a que faz as coisas acontecerem ou não né? Então: eu tinha um pouco de dificuldade na minha expresSÃO... e aí comunicação foi... justamente pegar algo que:... eu tinha determinada habiliDAde de relacionamento de / de conVERsa... de... de... agiliZAR de mobiliZAR algumas coisas através da comunicação mas ao mesmo tempo... em várias vezes eu me pegava não conseguindo expressar aquilo que eu de fato:... queria dizer... então... esse NÓ... para mim... estudar comunicação foi um / um jeito de... desamarrar ou de / de... aprofundar isso... mas... hoje eu trabalho em um sisTEma de / de horá:rio de roti:na que ainda não é o que acredito para mim... é:... essa regularidade de... / de... ter que cumprir horá:rio de / de ter que estar num lugar de ter que:... fazer várias coisas do sistema CLT que:... que me: que me deixam um pouco:... intrigada nesse processo (mesmo) de / de... / de pensar se é isso que eu quero para mim...

E: e é:... agora eu gostaria que... se você pudesse... narrAR... algum momento: que foi difícil na sua vi:da... porque: ele foi difícil... algum momento que você teve uma dificulDAde maior... em qualquer um dos... níveis assim... sociAL... é pessoAL... no níveJ: de traBAlho...

S: é:... acho que $\mathrm{n} /$ acho que foram:... VÁrios momentos de:... de dificul / os meus maiores momentos de dificulDAde.. foram... enquanto criANça... (mas) um:... quando se falava de / quando eu era tratada de maneira diferente por ser negra então os processos que eu / que eu vivi de racismo foram muito difíceis para mim... quando pequena era difícil porque eu não entendia porque as pessoas estavam me tratando:... de um jeito difeRENte... estavam me xinGANdo ou... briGANdo comigo... NA adolesCÊNcia: era um processo de: / de: rejeição muito forte porque na / na descoberta do / do corpo na descoberta das coisas as minhas amigas as gurias que estavam no meu entorno: se relacioNAVAM meLHOR com as outras pesSOas ou no processo de amiZAde no processo de relacionamento afetivo... eu en / eu enten / já entendia porQUE que era que eu / eu era negra mas não aceitava ao mesmo tempo me culpava por isso... eu acho que esses foram os momento mais difíceis porque a partir do momento que eu $\mathrm{m}$ / eu me:... descobri... as minhas capaciDAdes eu me descobri como NEgra descobria... até mesmo:... minha bele:za... eu passei a lidar: de um jeito diferente com o racismo né?... passei a me defender:... e: a... estudar... descobrir o porquê desse processo então... é:... depois de 
jovem adulta isso: foi um OUtro jeito foi até uma: um imPULso né?... de de / de viVER de questioNAR de de / de: buscar refeRÊNcias e até mesmo de: ser referência para / para outras pessoas... mas... ANtes disso até:... eu ter esse despertar e... foi muito difícil... acho que:... é isso

E: legal... bom você já falou um pouco mas: eu já ia até fazer essa pergunta... é::... você foi vítima de racismo? já foi foi vítima de algum outro tipo de violência? E se você considera que isso: dificultou: a sua / o seu / o seu processo de construir uma vida própria

S: mas / s / já: fui vítima de racis:mo... me / em todos os níveis Acho... enquanto crianças pelas outras criANças de a / enquanto crianças de adulto contra criANça... depois como jovem de jovem para jovem... é:... esse processo me... di-fi-cul-tou: fo / foi difícil $p$ / para mim enquan / enquanto crianças adolescente de:... porque eu... gosTAva... do / do meu cabelo por exemplo gosTAva do meu caBE:lo... mas:... eu entendia que eu não era aceita: no grupo ou não era aceita: no contexto por conta do meu cabelo aí eu passei a: aliSAR o cabelo... e esse processo foi violento para mim primeiro porque eu não gostava do jeito que ficava o meu cabelo... e segundo... porque:... era um / uma:... normatização né?... eu fazia aquilo para me encaixar... e ãn / a prime / eu lembro: / é muito CLAro assim a primeira vez que eu fiz ((risos)) relaxamento que o cabelo balançava eu saía na rua com aquele cabelo balançando e balançava para lá e para cá e pô eu fiquei uma semana assim super-empolga:da... aí de repente quando eu: / quando eu olhei no espelho e tipo: "que / quem é essa pessoai aí né?" e aí foi vã / muitos anos até eu / eu parar... sei lá acho... que com QUINze... quaTORze quinze Anos e daí depois... eu usei química até os vinte e três... quase dez / dez Anos de / de / de uma:... roTina de / de / de ir para o cabeleireiro de esticar do cabelo cair de quebrar daí faz o jeito para... \{E: você fazia:... diariamente? \{S: era o m / mã / não era diariamente né? sei lá eu ía para o salÃO... cada dois meses para / para fazer química ou ahn... era o cabelo cresCER... começar um raizinha a crescer e já tinha que alisar né?... já tinha que esticar então: / então até:... e para EU... toMAR: a atitude de: / de deixar de usar química foi isso eu... estava em um processo de usar química usar química aí de repente eu fui mudar de um produto para ver se ele ficava Menos artificial... e aí o cabelo caiu... caiu que ficou... muito curto / muito quebrado aí eu falei: "chega"... aí corTEl... o que dava para cortar... e falei: "a partir de agora eu não vou mais fazer isso"... e aí foi uma descoberta inCRÍvel de descobrir como é que ele / de relemBRAR como é que era o meu caBElo de texTUra de ver ele cresCER de v / de ver... várias descobertas assim e foi / foi be:m... legal... e eu acho que outro tipo de violência que foi uma coisa até que eu me dei conta:... recentemente... $f$ / foi / foi uma violência seXUAL quando eu era criANça... foi uma vez... que eu fui no piquenique do corAL... e:.... e aí tinha um cara que estava ensinando a nadar... e eu era louca para aprender a nadar... "ah me ensina me ensina" teve uma hora que ele me levou para o fundo da pisClna... e aí ele tenTOU / tentou me agarrar assim... eu lembro que eu não gritei... que eu $\mathrm{n}$ / que eu fiquei: tipo: catatônica com aquilo mas aí eu me segurei na beirada da piscina e fui / fui / fui: até... / fui num lugar que dava pé assim... isso reverberou em / em várias outras / várias... primeiro que eu: nunca mais quis nadar... né? eu lembro que eu contei para a minha mãe... mas também não entendia muito o que tinha acontecido e a minha mãe ficou:... super-revoltada mas... também eu acho que a gente não foi atrás... da pessoa... e aí ((clique com as mãos)) isso teve meio que um apagão assim... eu esqueci... e aí eu fui lembrar aGOra tipo... pensanso né meu "eu sou louca para aprender a nadar mas porque que eu não fui resolver isso de: aprenDER a nadar de procurar... e aí eu lembrei dessa situação que foi uma situaÇÃO... quando eu tinha sei lá nove dez Anos... e que: / que trouxe né? que / que / esse tipo de violência marcou de um jeito que veio para... até hoje assim... já (acho isso) acho / acho que o que esses processos de racismo foram:... é:... muito fortes no / na / na contr / na minha construção de identiDAde... mas eu precisei de / de / de enconTRAR outras referências... né? eu / eu sou de uma cidade peQUEna... que tem uma visão:... muito limitada ainda de diversidade... talvez hoje esteja um pouco melhor mas na época DEZ anos atrás era... muito limitado... e aí quando eu saí de lá... nas / nas minhas viagens... com / com / 
com: eu trabalhava com protagonismo juvenil na esCOla... várias ou / e aí eu fui ver outras referências fui conhecer outras pessoas e isso:... me fez despertar para várias outras: coisas... E: legal... é:: então JÁ: aproveitando que você tocou nessa: / nessa questão da sua identidade... enquanto / enquanto mulher NEGRA... é:... você considera / como você vê... é:... que isso se relaciona com: / com a sua vida como uma pessoa independente... é... e: / e a sua construção de identidade... como mulher negra?

S: é::... quando eu / quando eu / eu vou: estudar: dos / dos processos de equidade de gênero... penSAR... é:... na pirâmide mesmo dos empre:gos e salários... eu descubro que: a mulher recebe mais / recebe menos do que os homens e que a muLHER NEgra recebe menos que as mulheres brancas... então a gente tem uma escala de quatro e eu sou / e eu sou: o / a última né? na escala... e quando eu / eu olho pro meu entorno familiar e e percebo que:... da / do lado do meu pai eu sou a / a primeira pessoa a chegar numa universiDAde... quando eu olho para a minha hisTória... de gerações e / e / e: descubro que: / que eu sou:... a primeira geração da minha família que não passou fome... é::... pós-escravidão... eu conCLUO que tem uma coiSA erRAda aí... ne / nessa conta... né? não está somando no meu processo de / de: / de enquanto mulHER... uma que eu sei... e daí... se eu olho se eu vou olhar: para / para a realidade brasileira... e eu sei que eu sou uma privilegiada... enquanto mulher negra de ter acesso à universiDAde ter acesso à / à empre:go a poder me sustentar:... aqui em São Paulo e me manter:... sozinha e de ter acesso a várias coisas em relação a / a cultura e de muitas vezes estar em lugares que: onde só / só tem eu de: um / de mulher NEgra... é:... isso:... me faz... penSAR penSAR no / em qual é o meu papeJ: / em qual (é) a minha: / que que eu tenho que fazer para mudar essa realiDAde né? qu /quaJ: que é o meu papel na / na construção de uma / de uma sociedade: mais:... é:... não vou dizer justa mas de uma sociedade em que:... todos tenham o acesso / ou que todos tenham:... oportunidades então... a minha construção de: / de identidade... enquanto mulher NEgra é mui / muito de: / de olhar para o meu entor:no e de perceber: / e de perceBER: quais são as coisas que para mim ainda não / não são:... certas e de tentar: lut / lutar para isso... primeiro em me fortalecer enquanto / acho que isso tem me vindo muito forte: aGOra assim de de cada vez estuDAR MAIS cada vez... é:... me fortalecer nesse sentido... e: de penSAR junto né o que que a gente pode fazer para / para mudar esse quadro... não sei se eu respondi a pergunta... (viagem fui em várias outras coisas) E: é:... m / a / é o que te motiVOU a busCAR:... é:... levar uma vida... mais autônoma? S: eu acho que... não sei... primeiro para ter uma: / uma realidade ou uma experiência diferente... dos meus pais... é:... segundo porque eu sempre / sempre gostei de / desse: / dessa pegada de estar mais: independente de fazer minhas COlsas... de escolher o que eu quero faZEr de escolher o que eu quero estudar eu acho que / que uma das coisas que / que fiCOU muito da / da minha formaÇão da / da educação que que recebi... dos meus pais e mais ainda da minha mãe é que:... é:... eu podia ser... várias coisas... que eu tinha oportunidade de / de:... de SER né? de estuDAR... de / de trabaLHAr de buscar por isso então... eu acho que / que::... foi isso né? oportunidade de vir a São Paulo foi um convi:te... que eu abracei: e: em uma semana que estava: moran:do aqui... mas antes eu tinha morado em Curiti:ba também sozinha eu acho (que com) dezoito anos morei um semestre em Curitiba... \{E: hum... é... da onde você é? \{S: eu sou de... uma cidade... no norte do Paraná... cidade de cento e vinte mil habitantes... é:... acho que é isso... mais por uma vontade de traçar o meu caminho assim... independente né? dos outros... não que eu não dependa que não seja ligada a: / a minha família... muito pelo contrário né... eu sou MEga... / MEga ligada... mas é mais por uma vontade de traçar um caminho:... autônomo... independente...

E: é:... para você o que é ser Llvre?

S: liberDAde... liv / ser livre para mim... é:... é muito difícil... ser livre né? porque... depende de / de / de ou / a minha liberdade depende da / do limite do outro né? dessas barreiras... mas não sei... se for tratar de / de: liberdade:... tá... eu vou usar um / fiquei pensando aqui... quando a gente estava falando do raCISmo e:... talvez um... pouco seja isso né?... ser livre é 
poder ser quem eu sou na minha essência né?... na miNHA... no / nos meus gostos do jeito que eu SOU... na minha... natuREza...

E: você diria que a sua família te auxiliou no caminho de se tornar uma pessoa livre?

S: com certeza... primeiro... como eu contei da minha infância é:... minha mãe / meus pais sempre tiveram que trabalhar então a gente teve que se virar né?... que fazer... de:... cuidar da CAsa... de cuidar do meu irMÃO... de... fazer as minhas coisas de ir para a creche de ir para a escola sozinha... me arrumar sozinha... então... desde pequena a g / a gente:... aprendeu a ter autonomia nesse sentido... de se organizar para que as coisas andassem... ((suspiro)) segundo porque sempre tive es / esse:... esse: / eu sempre escutei né?... da minha mãe... que é... que eu podia... ser o que eu quisesse... né? podia ter uma realidade diferente da dela por exemplo que... tem até a quarta Série que... que sempre trabaLHOU para que:... eu e meu irmão tivéssemos oportunidades né? de vida (então)... acho que isso: contribuiu

E: existe alguma pessoa que te inspirou... a querer viver a sua própria vida?

S: ah eu acho que eu não consigo pensar ninguém diferente da minha mãe... ((risos))... na infância é a minha MÃE... e.... na faculdade... tá vamos voltar na escola tem uma professORA... que:... que:... me ajudou um pouco... porque eu sem / eu sempre:... já na escola eu trabalhava com protagonismo juvenil... eu tinha um proje:to... quando eu tinha treze quatorze anos que: era de de: / para instigar as pessoas a doarem sangue a gente não podia doar porque a gente não tinha dezoito anos... mas a gente podia convencer as pessoas a doarem... e eu sempre fui muito briguenta... é:... desde pequena... primeir / antes de entender do: / briguenta de bater mesmo:... me xingavam eu batia... mas depoi / depois de adolescente já era um briguenta de discutIR de questionAR e teve uma época da minha vida que eu dei uma paRAda assim uma aPAGAda nisso... fiquei meio / meio deprê meio... meio... meio não questionadora... e aí... aí uma professora uma vez me chamou e falou assim "S..... porque que você deixou de ser briguenta por que que você parou de questionar? porque que você:... é:: se escondeu né?..." e isso:... reverberou na minha vida... depois dessa conversa... e aí:... voltei a ser / ser briguenta mas (dessa vez) de / de um / de um jeito:... diferente... por /por buscar mais... os meus objetivos as minhas vontades... na faculdade... tenho... tive uma professora que: que hoje é minha amiga... que me inspirou / que me inspira muito até hoje... nesse sentido de.... da liberdade conquistada sabe?... de es / de estuDAR MAIS... de trabalhar... de ir atrás... isso foi legal... me inspirou bastante... a da escola é professora lara e a da faculdade é a professora Juliana... mulheres ((risos))... três mulheres...

E: legal... existe alguma pessoa que:... você sente que dificultou... esse processo... de você viver sua própria vida?

S: no processo de viver minha própria vida acho que não... uhm

E: para você o que é trilhar o seu próprio caminho?

S: trilhar o meu próprio caminho?... o que que é?... ((suspiro)) eu acho que que é um pouco de:... primeiro... me conhecer né... quais quais as / as minhas: / as minhas vontades os meus desejos que eu gosto que eu não gosto (então eu estou) muito ness / ness / nesse momento agora de de: de encontrAR de me encontrar e de encontrar o que que eu vou fazer daqui para a frente... e:... e respeitar isso... e outra coisa é de também valorizar o que que:... o que que: o universo... o que que:.. o que que a minha intuição está pedindo...

E: uhum... é:... dentro da:... desse processo né de:... começar a se tornar uma pessoa mais independente ãhn... você se / sentiu que que ele foi uma / um processo tranquilo ou foi um processo turbuLENto com muitos: obsTÁculos...? como é que foi isso essa mo / assim essa sensação?...

S:... eu acho que... ANtes aí na / na adolescência tinha / eu tive SEMpre muita vontade de de: me tornar independente de: de sair para o mundo... mas ao mesmo tempo eu tinha muito medo eu acho que o medo de de de:... sair de casa de: fazer es / fazer escolhas e: bancar as escolhas é uma uma coisa de de dificuldade mas... é isso... acho que:... naturalmente eu fui... vencendo esses esses obstáculos... tive um tempinho de: depressão e dos quinze aos dezesseis... de não me encontrar de não querer:... sair de não querer... é:... de não querer 
fazer nada ((risos))... mas aí depois pasSOU... e aí as coisas foram acontecendo... foram surgindo oportunidades eu fui abraçando... (que me) me:... propuseram isso...

E: então vamos fazer uma última pergunta... você acredita que a sociedade brasileira favorece os jovens a serem livres?...

S: ((suspiro)) eu acho que... a sociedade brasileira está muito arraigada... em muitos:... mitos... é::... ainda... da da religiẽ̃ da... da sexualiDAde... da... tem ainda muitos:... é:... quadrados né? tem muitos quadrados que a gente / que a gente vai sendo enfiado desde a esCOla... até:... sendo formatado assim... acho que a educação não não possibilita... a: a criação... o sistema:... o preconceito até mesmo... e o racismo... colocam as pessoas num num quadrado que não:... impulsiona a liberDAde... as pessoas tem medo de saírem... por exemplo:... se for pegar o índice dos assassinatos dos meninos negros no Brasil... e assassinatos por policiais é uma coisa... absurda... então... a sociedade brasileira... não s / é louco que: que não só o sistema... o sistema de polícia o sistema de educação... mas também:... as pessoas né... muito ainda arraigadas a várias coisas que:... estão muito ainda no "porque foi Deus que quis porque Deus que quer ou porque: tinha / as coisas tinham que acontecer desse ou de outro jeito..." então... que acaba não propiciando: uma liberdade genuína né?... de escolhas de:... de buscas... MAS... ao mesmo tempo... eu VEjo e eu coNHEço... muitos jovens e muitas crianças até mesmo... que têm questionado esse sistema... é:... então... eu acredito que está surgindo uma nova construção de sociedade... é:... de sociedade brasileira... é:... acho que a gente vive um momento histórico que é:... das pessoas irem para as ruas e muit / e: por causas distintas... é::... acho que as redes sociais propiciam uma:... / uma: agilidade e uma facilidade de acesso: às notícias e as notícias que de fato acontecem não só das grandes mídias não só... dos grandes meios de comunicaÇÃO... então as pessoas têm tido a p / a: possibilidade de serem... é:... contadoras de: várias histórias... de poderem mostrar outras versões... então:... eu acredito... que a a a vida: para as próximas gerações das crianças de hoje vão ser... diferentes da nossa... assim... de uma construção para a liberdade mesmo e a / e é uma coisa: acho que é... e é até interesSANte... que é... fa fa falei sobre isso essa semana que: que / falei não ouvi essa semana que liberdade tem a ver com responsabilidade também né... você precis / você precisa ser responsável para você ser livre... então... essa construção... eu vejo cada vez mais forte... mas:... é:... e liberDAde também... ela acontece através da educação... então... existe um buRAco muito grande na:... na educação... sobretudo dos pobres... de acesso mesmo de / eu t / eu traBAlho com: com crianças e adolescentes muitas vezes eu eu esbarro com com: jovens de quatorze anos analfabetos... - mas que estudaram... passaram aí seis sete anos estudando e que ainda são analfabetos... então... tem uma contradição né?... de que o sistema: está muito raso... mas ao mesmo tempo... tem um.... um pulsar aí de: de novos caminhos...

E: tá bom ((risos)) ... 


\section{Perguntas realizadas - Entrevistas sobre emancipação}

\section{ENTREVISTA AV24}

1 - queria que você falasse seu nome, profissão e data de nascimento

2 - você é familiar com o conceito de emancipação? o que isso significa para você?

3 - você se considera uma pessoa independente?

4 - você se lembra da primeira coisa que você fez no caminho de se tornar independente?

5- -que atitude você toma no seu dia-a-dia para se manter independente?

6 - existe alguma pessoa que te ajudou a se emancipar?

7 - com a questão do preconceito racial... você sente que isso é um empecilho para alguma pessoa se tornar independente ou é uma coisa que que não faz tanta diferença?

8 - pensando na sua vida, você diria que no seu atual estado você está se emancipando, já se emancipou ou ainda vai se emancipar?

\section{ENTREVISTA CS20}

1 - eu gostaria que você falasse seu nome sua idade e sua profissão

2 - você se considera uma pessoa independente? por que?

3 - você lembra da primeira coisa que você fez na sua vida? Qual foi a primeira coisa que você fez na sua vida para se tornar independente?

4 - qual é a coisa mais recente que você fez para se tornar independente?

5 - para você, o que significa ser uma pessoa independente? o que é ser uma pessoa independente?

6 - o que você faz para se manter independente?

7 - existe uma pessoa que foi especial no seu caminho de se tornar independente?

8 - como você se sente sendo uma pessoa autônoma?

9 - teve algum momento da sua vida em que você sentiu que a sua vida independente não estava acontecendo ou que tinha alguma coisa que impedia que você pudesse seguir o seu caminho? que momento foi esse?

10 - você já foi vítima de preconceito racial ou algum outro tipo de violência? você acha que isso pode ter te atrapalhado a se tornar uma pessoa independente?

11 - qual o momento mais intenso da sua independência, da sua emancipação?

12 - você pretende sair de casa?

\section{ENTREVISTA JS23}

1- qual é seu nome completo e idade?

2 - você se considera uma pessoa independente? por que?

3 - o que você busca ou buscava quando você estava começando a procurar ter mais liberdade e autonomia na sua vida?

4 - você se tornou independente porque quis?

5 - você sentiu que teve, por assim dizer, alguma pressão de alguém da sua família ou de alguma outra pessoa para que você se emancipasse? Ou foi uma coisa que veio de você mesmo?

6 - existe alguma pessoa que é importante para te incentivar?

7 - você acredita que a sociedade favorece os jovens a ser tornar independentes?

8 - como foi que você se tornou assim emancipado, uma pessoa independente, como foi esse processo? pode ser tanto na questão do trabalho, quanto de relacionamentos, quanto de religião (se você tiver, ou não...)

9 - você se sente bem sendo uma pessoa autônoma?

10 - dentro desse processo se tornar independente / emancipado, você passou por algum momento difícil?

11 - você já foi vítima de racismo em alguma situação? 
12 - você sente que o racismo é uma coisa que dificulta o processo das pessoas construírem as próprias vidas?

13 - você tem alguma história assim para contar que seja sua ou de algum aluno seu nesse sentido?

14 -outros tipos de exclusão que você gostaria de mencionar?

15 - esse tipo de violência doméstica que você mencionou no trabalho, ou de outro tipo de violência também tem um impacto grande sobre: a capacidade das pessoas se tornarem independentes?

16 - dentro do bairro que você vive você já ouviu alguma história desse tipo de violência? Você já teve acesso a essas histórias?

17 - mais alguma coisa que você gostaria de acrescentar sobre a sua história ou sobre a sua infância ou juventude?

18 - sobre essa zona de conforto? o que é para você essa zona de conforto? existe algum tipo de comportamento que você identifica?

\section{ENTREVISTA SM28}

1 - diga o seu nome, idade e estado civil.

2- como era sua vida quando você era criança?

3 - como é o seu dia a dia hoje?... o que você faz normalmente do momento que você acorda até o momento em que você vai dormir?

4 - qual é a sua profissão? e a sua formação? o que você faz hoje?

5 - qual é a sua paixão?

6 - para você o que é ser jovem?

7- o que é ser adulto?

8 - você se considera uma pessoa que faz o que quer?

9 - você poderia narrar algum momento difícil na sua vida? Por que ele foi difícil?

10 - você foi vítima de racismo? Já foi foi vítima de algum outro tipo de violência?

11 - como você vê que isso se relaciona com a sua vida como uma pessoa independente e a sua construção de identidade como mulher negra?

12 - o que te motivou a buscar levar uma vida mais autônoma?

13 - para você o que é ser livre?

14 - você diria que a sua família te auxiliou no caminho de se tornar uma pessoa livre?

15 - existe alguma pessoa que te inspirou a querer viver a sua própria vida?

16 - existe alguma pessoa que você sente que dificultou esse processo de viver sua própria vida?

17 - para você o que é trilhar o seu próprio caminho?

18 - você sentiu que que ele foi um processo tranquilo ou foi um processo turbulento, com muitos obstáculos?

19 - você acredita que a sociedade brasileira favorece os jovens a serem livres? 